ХАРКІВСЬКИЙ НАЦІОНАЛЬНИЙ УНІВЕРСИТЕТ ВНУТРІШНІХ СПРАВ КРИМІНОЛОГІЧНА АСОЦІАЦІЯ УКРАЇНИ МІЖРЕГІОНАЛЬНА АКАДЕМІЯ УПРАВЛІННЯ ПЕРСОНАЛОМ ЗАХІДНО-РЕГІОНАЛЬНА АСОЦІАЦІЯ КЛУБІВ ЮНЕСКО АКАДЕМІЯ ЮРИДИЧНИХ НАУК МОЛДОВИ ІНСТИТУТ ДЕМОКРАТІЇ МОЛДОВИ НАЦІОНАЛЬНА АКАДЕМІЯ ПРАВОВИХ НАУК УКРАЇНИ МІНІСТЕРСТВО ЮСТИЦІЇ УКРАЇНИ

\title{
HAIIE MPABO
}

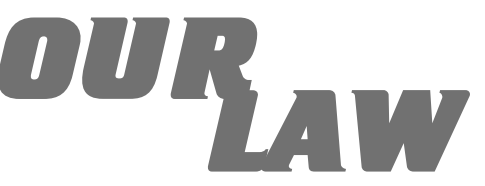

KHARKIV NATIONAL UNIVERSITY OF INTERNAL AFFAIRS

CRIMINOLOGICAL ASSOCIATION OF UKRAINE

INTERREGIONAL ACADEMY OF PERSONNEL MANAGEMENT

WEST REGIONAL ASSOCIATION OF UNESCO CLUBS

ACADEMY OF LAW SCIENCE OF MOLDOVA

INSTITUTE FOR DEMOCRACY OF MOLDOVA

NATIONAL ACADEMY OF LEGAL SCIENCES OF UKRAINE

MINISTRY OF JUSTICE OF UKRAINE

\section{Ne 3, 2020}

Спеціалізоване
видавництво




\section{MICT}

\section{ТЕОРІЯ, ІСТОРІЯ ДЕРЖАВИ І ПРАВА, КОНСТИТУЦІЙНЕ ПРАВО}

БАНДУРКА С.С.

МЕТОДИ ДОСЛІДЖЕННЯ ВЗАЕМОДІЇ ДЕРЖАВИ І АДВОКАТУРИ

В ІСТОРИКО-ПРАВОВОМУ ВИМІРІ

КУЗЬМЕНКО Н.О.

РЕФОРМА АДМІНІСТРАТИВНО-ТЕРИТОРІАЛЬНОГО УСТРОЮ УКРАЇНСЬКОЇ СРР 1930 РОКУ

ТА ІІЇ ВПЛИВ НА ЖИТТЯ НАЦІОНАЛЬНИХ МЕНШИН .10

\section{АДМІНІСТРАТИВНЕ ПРАВО}

ШВЕЦЬ Д.В., СВДОКІМОВА О.О.

ПОЛІЦЕЙСЬКА ОСВІТА: ЕВРОПЕЙСЬКІ ПІДХОДИ ДО ОРГАНІЗАЦІЇ

ТА ТЕНДЕНЦІЇ РОЗВИТКУ..

БАНДУРКА О.О.

АДМІНІСТРАТИВНО-ПРАВОВЕ ЗАБЕЗПЕЧЕННЯ КОРПОРАТИВНОГО УПРАВАІННЯ

ОБРУСНА С.Ю., ГОАОВАЧ О.А.

ПУБЛІЧНІ ПОСЛУГИ У СФЕРІ ПІДПРИЕМНИЦЬКОЇ ДІЯЛЬНОСТІ

ЯК АДМІНІСТРАТИВНО-ПРАВОВА КАТЕГОРІЯ.

ЗАВААЬНИЙ М.В.

ПЕРСПЕКТИВИ ЗАЛУЧЕННЯ ГРОМАДЯН ДО ОХОРОНИ ГРОМАДСЬКОГО

ПОРЯДКУ В УКРАЇНІ

БОРТНИК Н.П., ДМИТРИК Ю.І.

ПРАВОВЕ РЕГУЛЮВАННЯ СТАДІЇ ПІДГОТОВКИ ДО РОЗГАЯДУ СПРАВИ ПРО

АДМІНІСТРАТИВНЕ ПРАВОПОРУШЕННЯ В СУ ДАХ

ПАРПАН У.М., МАЛЕЦЬ М.Р., ВІТИК О.Д.

ПРИНЦИПИ ЮРИДИЧНОЇ ВІДПОВІДАЛЬНОСТІ ЗА ПРАВОПОРУШЕННЯ

У СФЕРІ ЗАБЕЗПЕЧЕННЯ ІНФОРМАЦІЙНОЇ БЕЗПЕКИ 
НОВИЧЕНКО А.

ОСОБЕННОСТИ АДМИНИСТРАТИВНЫХ ПРАВОНАРУШЕНИЙ

В СФЕРЕ МИГРАЦИИ В УКРАИНЕ. .57

CMAЗНА T.M.

МОБІЛЬНІ РЕСУРСИ АДМІНІСТРАТИВНИХ ПОСАУГ В УКРАЇНІ

.61

НЕСТЕРЕНКО А.О.

МЕХАНІЗМИ ЗАБЕЗПЕЧЕННЯ ПРАВ ДІТЕЙ В ІНФОРМАЦІЙНОМУ СЕРЕДОВИЩІ .65

\section{КРИМІНАЛЬНЕ ПРАВО, КРИМІНАЛЬНИЙ ПРОЦЕС ТА КРИМІНАЛІСТИКА}

ДАНИЛЬЧЕНКО Ю.Б.

МОТИВАЦІЯ ІНДИВІДУАЛЬНОЇ ЗЛОЧИННОЇ ПОВЕДІНКИ,

ПОВ'ЯЗАНОЇ 3 ТЕРОРИЗМОМ

АИСЕНКО C.O.

МАЙБУТНІЙ ПОГАЯД НА ОРГАНІЗАЦІЮ БЕЗПЕКИ: ФОРСАЙТ БЕЗПЕКИ

І ЯК НИМ КОРИСТУВАТИСЯ .78

МАЛИНОВСЬКА Т.М.

ДОМАШНЕ НАСИЛЬСТВО: ЩОДО ЗМІСТОВНОГО НАПОВНЕННЯ ТЕРМІНА.

. .85

ОСМОАЯН В.А.

АУ ДИТ ЯК НЕВІ Д'СМНА СКААДОВА КРИМІНАЛІСТИЧНОЇ МЕТОДИКИ РОЗСЛІДУВАННЯ

ЗАОЧИНІВ У СФЕРІ ГОСПОДАРСЬКОЇ ДІЯАЬНОСТІ ………………………………………............92

КОРЕЦЬКА В.В.

МЕЖІ СУ ДОВОГО РОЗГАЯДУ

ГОНЧАРУК В.А.

ВИДИ ПРЕДИКАТНИХ ЗАОЧИНІВ У ВІТЧИЗНЯНОМУ

КРИМІНАЛЬНОМУ ЗАКОНОДАВСТВІ

АЛЕКСЕСВА-ДАНИАЕНКО Ю.В.

МЕТОДОЛОГІЯ ДОСЛІДЖЕННЯ КРИМІНАЛЬНИХ ПРОСТУПКІВ

СМЕАЬЯНОВ Р.О.

ЗАРУБІЖНИЙ ДОСВІД РЕГААМЕНТАЦІЇ КРИМІНАЛЬНОЇ ПРОЦЕСУАЛЬНОЇ ДІЯЛЬНОСТІ

АДВОКАТА-ПРЕДСТАВНИКА ПОТЕРПІЛОГО

КОВААЕНКО Д.А.

ШКОДА ОДНА ІЗ СКААДОВИХ ЕАЕМЕНТІВ ТЕРМІНА «ПОТЕРПІЛОГО»

ЗА ПЕРЕШКОДЖЕННЯ З'ЯВ АЕННЮ СВІДКА, ПОТЕРПІЛОГО ЕКСПЕРТА, ПРИМУШУВАННЯ

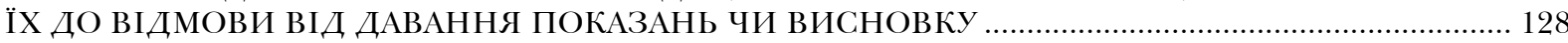

НУРИЕВ Э.

МЕЖДУНАРОДНО-ПРАВОВОЕ РЕГУЛИРОВАНИЕ БОРЬБЫ С АЕГАЛИЗАЦИЕЙ ДЕНЕЖНЫХ

СРЕДСТВ ИЛИ ИНОГО ИМУЩЕСТВА, ПРИОБРЕТЁННЫХ ПРЕСТУПНЫМ ПУТЁМ.

CIPOTKIHA M.B.

МІЖНАРОДНО-ПРАВОВІ ГАРАНТІЇ ПРАВА НА КОМПРОМІС

У КРИМІНААЬНОМУ СУДОЧИНСТВІ.

ФIAIПЕНКО Н.E.

КРИМІНОАОГІЧНА ДІЯАЬНІСТЬ

І ПИТАННЯ ПРАВОВОГО ВИХОВАННЯ НАСЕАЕННЯ 


\section{ЦИВІЛЬНЕ, ПІДПРИЕМНИЦЬКЕ, ГОСПОДАРСЬКЕ ТА ТРУДОВЕ ПРАВО}

ОРТИНСьКИЙ В.А.

ВЕКТОРИ РЕФОРМУВАННЯ НОТАРІАЛЬНОЇ ДІЯЛЬНОСТІ: ОКРЕМІ ЦИВІЛЬНО-ПРАВОВІ ТА КРИМІНАЛЬНО-ПРАВОВІ АСПЕКТИ

БОГОМАЗОВА I.O.

УДОСКОНАЛЕННЯ ПРАВОВОГО РЕГУЛЮВАННЯ ТРАНСПЛАНТОЛОГІЇ

У СВІТАІ ЕВРОПЕЙСЬКИХ СТАНДАРТІВ

ПОЧАНСЬКА О.С.

КЛАСИФІКАЦІЯ ГАРАНТІЙ ПРАВ ГРОМАДЯН, ЗАСУ ДЖЕНИХ

ДО ПОЗБАВ АЕННЯ ВОЛІ В УКРАЇНІ.

МАРТИНЮК Н.М.

ПРАВОВА ОСНОВА НАДАННЯ ПУБЛІЧНИХ ПОСАУГ СУБ’ЄКТАМИ ПУБЛІЧНОЇ

АДМІНІСТРАЦІЇ ЩОДО ДЕРЖАВНОЇ РЕЄСТРАЦІЇ РЕЧОВИХ ПРАВ НА НЕРУХОМЕ МАЙНО .... 171 


\section{МЕТОДИ ДОСЛІДЖЕННЯ ВЗАЕМОДІї ДЕРЖАВИ І АДВОКАТУРИ В ІСТОРИКО- ПРАВОВОМУ ВИМІРІ}

\section{м. Київ}

БАНДУРКА Сергій Сергійович - доктор філософї, адвокат АО «Креденс», DOI 10.32782/LAW.2020.3.1

\section{Вступ}

Конституція України ${ }^{1}$ у ст. 59 передбачає, що кожен має право на правову допомогу.В окремих випадках, передбачених законами, така правова допомога надається безоплатно. Кожна особистість $є$ вільною у виборі захисника своїх прав. Для забезпечення права на захист від обвинувачення та надання правової допомоги при вирішенні справ у судах та в інших державних органах в Україні діє адвокатура. Тобто держава надає можливість членам суспільства користуватись правом правової допомоги за участю представників адвокатури.

Закон України «Про адвокатуру та адвокатську діяльність»² визначає правові засади організації та діяльності адвокатури та здійснення адвокатської діяльності в Україні.

Завдання адвокатури із захисту забезпечення прав і свобод і законних інтересів особи, стосовно якої здійснюється досудове провадження чи судочинство та надання іншої допомоги правового характеру, і завдання держави, для якої права і свободи людини та їх гарантії визначають зміст і спрямованість діяльності держави, а утвердження і забезпечення прав і свобод людини є головним обов'язком держави, як бачимо, співпадають. Держава та адвокатура мають взаємодіяти в діяльності із захисту прав і свобод людини.

\footnotetext{
${ }^{1}$ Конституція України : Міністерство юстиції України // Офіційне видання. - К., 2006.

${ }^{2}$ Про адвокатуру і адвокатську діяльність : Закон України // Відомості Верховної Ради України (ВВР), 2013. - № 27. - C. 282.
}

Взаємодія держави та адвокатури в системі захисту прав і свобод людини в Україні має тривалий історико-правовий вимір і набуває особливої актуальності в нинішній час, коли в Україні відбуваються радикальні реформи в державному управлінні, в судочинстві, в економіці, розвитку, в розбудові громадянського суспільства і в процесах євроінтеграції.

Мета статті полягає у визначенні методів дослідження взаємодії держави і адвокатури в системі захисту прав і свобод людини.

Наукова дослідженість проблеми: взаємодія держави і адвокатури в системі захисту прав і свобод людини знайшла своє відображення в наукових працях Гвоздія В.А., Варфоломєєвої Т.В., Вільчик Т.Б., Тацій А.В., Узун Н.Ф., Сопілко І.М., Святоцької В.О., Курило Т.В., Аракелян М.Р. У їх працях представлено різноманітні аспекти і результати досліджень, які безпосередньо стосуються сфери професійної діяльності адвокатів. Віддаючи належне вказаним та іншим ученим у дослідженні проблем діяльності адвокатури в Україні, слід однак зауважити, що методи дослідження взаємодії держави і адвокатури в історико-правому вимірі належного висвітлення не знайшли.

Виклад основного матеріалу

Згідно зі ст. 5 Закону України «Про адвокатуру і адвокатську діяльність» адвокатура є незалежною від органів державної влади, 


\section{Теорія, історія держави і права, конституційне право}

органів місцевого самоврядування, їх посадових та службових осіб, а держава створює належні умови для діяльності адвокатури та забезпечує дотримання гарантій адвокатської діяльності.

Як вважає С.Антонюк, варто зазначити, що у зв'язку з проведенням системних реформ в Україні (практично в усіх ключових напрямах життя держави), включаючи реформування української судової системи, інститут правової допомоги сьогодні зазнає певних суттєвих змін, зокрема, на конституційному рівні. ${ }^{3}$

3 огляду на це правовий аналіз методів дослідження взаємодії держави і адвокатури в системі захисту прав і свобод людини набуває особливої актуальності.

Для сучасного правознавства, яке розвивається в період глибинних реформ, докорінних перетворень українського суспільства, методологічні дослідження спрямовані на виявлення шляхів удосконалення правоохоронної та правозахисної діяльності.

Як зазначають М. Кельман та I. Коваль, у сучасній вітчизняній юридичній науці вирішення методологічних проблем - об'єктивна вимога часу, оскільки поступ у розумінні дуже складного явища права можливий завдяки гіпотезам, концепціям, теоріям, школам, неабияка частина яких представники, так би мовити, неюридичних наук. I зважаючи на «демонополізацію» вітчизняної методології досліджень права та проникнення в правознавство висновків інщих наук, наслідком якого стала «плюралізація» правових компетенцій, є підстава констатувати, що саме завдяки неюридичним наукам можливий новий стрімкий розвиток вітчизняного правознавства. ${ }^{4}$

Аналізуючи адвокатську діяльність у різні періоди, ми бачимо, як у діяльність адвокатури проникає логіка, філософія, етика і естетика, психологія, соціологія, педагогіка, інформатика, економіка, корпоративне управління, публічне адміністрування та інші галузі

\footnotetext{
${ }^{3}$ Святослав Антонюк Міжнародно-правові стандарти професійної діяльності адвоката у цивільному судочинстві України (Підприємництво і господарське право). - К., 2019. - № 6. - С. 347 (С. 347-353).

${ }^{4}$ М. Кельман, I. Коваль Методологія дослідження як наукове пізнання, 2016.
}

науки, що обумовлює широку методологію дослідження проблем взаємодії держави та адвокатури в системі захисту прав і свобод людини.

Методологія дослідження - це система теоретичних і практичних знань, яка використовується при вивченні певних явищ, фактів, подій, документів та інших об'єктів дослідження. Методологія - сукупність прийомів дослідження, що застосовуються у будь-якій науці; вчення про метод наукового пізнання світу; принципи побудови методів, їх наукове узагальнення. ${ }^{5}$

Методологія (від грецьк. «methodus» шлях дослідження, вивчення, пізнання i «logus»- вчення), тобто це сукупність підходів, способів, прийомів та процедур, що застосовуються в процесі наукового пізнання та практичної діяльності для досягнення поставленої мети. Метод, як уже було зазначено, грецьке «metodos» буквально - «шлях до чого-небудь», розуміється також як спосіб соціальної діяльності в будь-якій формі.

Кожний об'єкт дослідження потребує своїх методів. Неможливо створити загальний, універсальний метод пізнання. Кожний об'єкт дослідження характеризується своїми особливостями, специфічними якостями, а отже, дослідження такого об'єкта потребує своєрідних методів і методологічних досліджень.

Багатоманітність адвокатської діяльності, широкий спектр взаємодії 3 органами державної влади, місцевого самоврядування, суб'єктами господарювання, об'єднаннями громадян і окремими громадянами обумовлюють розмаїття методів дослідження різних сторін адвокатської діяльності.

«Загальною методологією всіх галузей наукового пізнання виступає філософія з ії специфічною функцією методу пізнання. Сама собою філософія не містить ні готового рішення наукових проблем, ні готових способів їх добування, але вона вказує на шляхи пошуку, визначає загальну стратегію дослідження, допомагає виявити значення і місце всіх засобів наукового пізнання. Закони діалектики, філософські принципи, положення

\footnotetext{
${ }^{5}$ Енциклопедія бізнесмена, економіста, менеджера. - К., Міжнародна економічна енциклопедія, 2000. C. 360 (703 c.).
} 
гносеології виступають як логіко-методологічні принципи переходу до нового знання».

Методологія дослідження будь-якого предмета дослідження, у т.ч. і дослідження взаємодії держави та адвокатури, грунтуються на таких загальнонаукових принципах, як: історичний, термінологічний, функціональний, системний, пізнавальний (когнітивний), синергетичний та інші. Загальнонаукові принципи обумовлюють вибір методів дослідження.

До нашого часу дійшли перші письмові джерела права Київської Русі та договори Київської Русі з Візантією 907, 911, 944, 947 років. У цих правових документах уже передбачено заходи захисту інтересів договірних сторін і заходи покарання за порушення встановлених норм. Для того щоб зрозуміти сутність відносин фізичних осіб з державною владою, ступінь захисту і міри покарання, необхідно звернутись до того історичного періоду. Історичний підхід дає змогу дослідити виникнення, формування та розвиток процесів і подій у Київській Русі у хронологічній послідовності, виявити характер суспільних відносин у сфері правоохорони і правозахисту тодішньої державності на колишніх українських землях. Для пізнання взаємодії і взаємовідносин стародавньої Київської держави в особі їі органів (князів, намісників, дружинників та осіб, наділених владою) і особами, які здійснюють захист інтересів інших членів суспільства, доцільним буде використати історико-порівняльний метод, за допомогою якого можна залучити сукупність пізнавальних засобів і процедур, які дозволять виявити схожість і відмінність права Київської Русі та Візантії, Київської Русі та Великої Ясси Чингісхана, законів Київської Русі та норм пізніших Новгородського і Псковського Судебників, чи статусу адвокатури Аитовськопольської доби.

Оскільки правові документи Київської Русі дійшли до нас або не в повному обсязі, або в перекладі, важливим буде метод аналізу документальної інформації. Документальною інформацією буде будь-яка інформація,

\footnotetext{
${ }^{6}$ В.А. Тюрина, И.В. Влащенко Основы методологии и методики научного исследования : учебное пособие. -К., Международное финансовое агентство, 1992, С. 4 (44 с.)
}

зафіксована в письмовому чи друкованому вигляді, чи подана в цифровому чи в ма^юнковому (схематичному) зображенні. Iсторико-правовий метод дозволить вивчити розвиток подій, фактів, документів Київської Русі, зокрема, її суспільно-правове життя, в хронологічній послідовності 3 відповідним правовим регулюванням. Досліджуючи в історико-правовому вимірі взаємодію держави і адвокатури, доцільно використовувати і компоративний метод, коли шляхом порівняння, зіставлення можна виявити загальне у взаємодії держави і адвокатури і особливе, коли в держави і адвокатури є свої особливі інтереси і позиції, виявити причини цих подібностей і розходжень, тенденції і перспективи розвитку взаємодії. Дослідження подій і окремих фактів 3 історії взаємодії держави і права обумовлює застосування біографічного методу, що передбачає дослідження діяльності окремих політичних і громадських діячів, учених, свідчень очевидців, соціальних умов життя людини, культури, світогляду,

Досліджуючи систему правового захисту і зародження адвокатури на українських землях, ми звертаємось до постаті Ярослава Мудрого, Данила Галицького, Казиміра IV автора Аитовського судебника 1468 р., гетьманів Богдана Хмельницького, Мазепи, Павла Скоропадського, авторів судових статутів Російської імперії 1864 року, які розробили основу організації адвокатури.

Застосовуючи методи дослідження взаємодії держави і адвокатури в історико-правовому вимірі, не можна обійти історико-термінологічний метод, який передбачає вивчення змісту і сутності термінів і передбачуваних ними понять. Адвокат не завжди називався адвокатом. Професія правозахисника називалась у процесі розвитку правозаступництва по-різному. Сама назва Київської Русі, як давньоруської держави, з'явилась у кінці XVIII століття, а договір у Київській Русі називався «рядом», а назва Литовських статутів виникла вже після їх видання. Термінологічний метод дозволяе сформулювати ознаки, які позначають обсяг і зміст досліджуваних предметів, дає можливість описати, уточнити понятійний апарат конкретних подій, встановити взаємозв'язок понять, забезпечити їх доцільне і наукове використання. 


\section{Теорія, історія держави і права, конституційне право}

В усі часи інститут правозахисту, який нині сприймається як адвокатура, не діяв ізольовано. Він був складовою суспільної системи, діяв за законами і в порядку встановленому державою, функціонував у системі судочинства чи в іншій сфері, пов'язаний із застосуванням системи правових норм. Адвокатура завжди діяла системно як у внутрішніх, так і в зовнішніх зв'язках. Застосування системного методу дослідження взаємодії держави і адвокатури дасть можливість охарактеризувати всю сукупність елементів системи, в якій складаються відносини держави і адвокатури.

У системі взаємодії держави і адвокатури задіяні різні соціальні організації, зокрема суд, прокуратура, поліція, органи виконавчої влади, місцевого самоврядування, об'єднання громадян і окремі громадяни. Кожні взаємовідносини держави і адвокатури є своєрідною системою (підсистемою) конкретних прав і обов’язків, функцій, діяльності, структури. Системний метод забезпечить комплексне дослідження взаємодії держави і адвокатури в системі захисту прав і свобод людини і тих елементів (підсистем), які в тій чи іншій мірі мають стосунок до захисту прав і свобод людини.

Закон України «Про адвокатуру та адвокатську діяльність» визначає, що адвокатуру України складають усі адвокати України, які мають право здійснювати адвокатську діяльність. Вивчаючи історико-правовий характер взаємодії держави і адвокатури в системі захисту прав людини, необхідно орієнтуватись на метод цілісного пізнання, що дозволяє розглянути адвокатуру як партнера держави, як цілісний, єдиний організм, складові частини якого - адвокати органічно інтегровані в єдине ціле зі своєю структурою, функціями, взаємозв'язками із зовнішнім середовищем, ієрархічністю, цілеспрямованістю, самоорганізацією і самоврядуванням. У цьому випадку доцільним буде і використання структурно-функціонального методу.

Ієрархічно-правовий метод дозволяє досліджувати взаємодію держави і адвокатури 3 огляду на функції, компетенцію і повноваження суб'єктів такої взаємодії. Система адвокатури має свою ієрархію і самоврядування, а саме: З’ізд адвокатів, Рада адвокатів
України, Вища кваліфікаційно-дисциплінарна комісія адвокатури, Вища ревізійна компанія адвокатури, конференція адвокатів регіону, Рада адвокатів регіону, кваліфікаційнодисциплінарна комісія, Ревізійна комісія регіону. Органи адвокатського самоврядування поєднує Національна асоціація адвокатів України, яка діє через організаційні форми адвокатського самоврядування, передбачені Законом. Усі ієрархічні (структурні) підрозділи діють у межах своїх повноважень i обов'язків. Досліджуючи процеси саморганізації та самоврядування адвокатури та її взаємодії з державою, доцільно використовувати також синергетичний метод, який дозволить вивчити роль і місце кожного елемента адвокатури, їх діяльність, взаємозв'язки і взаємозалежність, ступінь матеріального, фінансового, інформаційного забезпечення, гарантій діяльності та інших умов функціонування.

Особливу роль у дослідженні взаємодії держави і адвокатури виконує метод правового регулювання. Метод правового регулювання полягає в застосуванні системи юридичних засобів, організованих найбільш послідовним чином 3 метою досягнення цілей, поставлених суспільством і державою в системі захисту прав і свобод людини. Метод правового регулювання взаємодії держави i адвокатури грунтується на нормах Конституції України, деталізується в Законі України «Про адвокатуру і адвокатську діяльність», у Кримінальному процесуальному кодексі України, в інших законах та нормативноправових актах.

Залежно від цілей і мети реалізація взаємодії держави і адвокатури в системі захисту прав і свобод людини можливе використання інших методів, зокрема анкетування, опитування, дослідження інформації і публічних повідомлень (інформаційний метод), метод критичного аналізу (аналітичний), спостереження, узагальнення та інші.

\section{Висновки}

Правознавство в сучасній Україні переживає період незвичайного підйому. Це обумовлено процесами побудови правової держави, розвитку громадянського суспільства, усвідомленням ролі особистості в громадському житті, утвердження принципу 


\section{АНОТАЦІЯ}

У статті розглянуті методологія та методи дослідження взаємодї держави $і$ адвокатури в системі захисту прав $і$ свобод людини. Дане визначення методологї $і$ методів дослідження, охарактеризовані окремі методи дослідження в історико-правовому вимірі взаємодії держави $i$ адвокатури, показаний зв'язок причин та умов, що обумовлюють вибір того чи іншого методу дослідження, доиільність їх використання з огляду на мету $i$ изілі дослідження. Наголошено, шо методи дослідження використовуються системно, що дослідник сам обирає, необхідні для досягнення поставленої мети, методи дослідження. Підкреслено, шоо в науиі немає єдиного універсального методу дослідження, придатного для всіх предметів дослідження, а є загальнонаукові і спеціальні наукові методи, які при комплексному застосуванні дають можливість провести повне і об'єктивне дослідження проблем взаємодії держави $і$ адвокатури в системі захисту прав і свобод людини.

Ключові слова: адвокатура, держава, система прав і свобод людини, методологія, методи дослідження.

верховенства права. Зростають потоки наукових досліджень у сфері юриспруденції, збільшуються обсяги підготовки спеціалістів юридичного профілю, зростає інтерес населення до правової сфери. Невипадково професія юриста, особливо адвоката, стала однією із найпрестижніших серед молоді.В Україні існують серйозні проблеми правового забезпечення економіки, екології, культури і освіти, охорони правопорядку, захисту прав людини. Адвокати, як посадові особи, працюють у різних установах як державного призначення, так і громадського. Вони знаходяться на передньому краї правових змін, адвокат не може не знати новітніх норм і положень, які з'являються в бурхливому потоці законодавчих і підзаконних актів. Тим паче, він має глибоко розумітись на взаємовідносинах адвокатури і державних органів, які складаються між ними в системі захисту прав і свобод людини. Методи дослідження взаємодії держави і адвокатури в системі захисту прав і свобод людини мають не тільки теоретичний характер, а й

\section{SUMMARY}

The article considers the methodology and methods of studying the interaction of the state and the bar in the system of protection of human rights and freedoms. This definition of methodology and research methods describes individual research methods in the historical and legal dimension of interaction between the state and the bar, shows the relationship of causes and conditions that determine the choice of a research method, the feasibility of their use given the purpose and objectives of the study. It is emphasized that research methods are used systematically, that the researcher chooses the research methods necessary to achieve this goal. It is emphasized that in science there is no single universal method of research suitable for all subjects of research, but there are general and special scientific methods which at complex application give the chance to carry out full and objective research of problems of interaction of the state and advocacy in protection of human rights and freedoms.

Key words: advocacy, state, system of human rights and freedoms, methodology, research methods.

практичний, оскільки служать удосконаленню діяльності як адвокатів, так і працівників правоохоронної та правозахисної сфери держави і суспільства.

\section{Література}

1. Антонюк Святослав Міжнародноправові стандарти професійної діяльності адвоката у цивільному судочинстві України (Підприємництво і господарське право). - К., 2019. - № 6. - С. 347 (С. 347-353).

2. Кельман М., Коваль І.Методологія дослідження як наукове пізнання, 2016.

3. Тюрина В.А., Влащенко И.В. Основы методологии и методики научного исследования : учебное пособие. -К., Международное финансовое агентство, 1992, С. 4 (44 с. )

4. Конституція України : Міністерство юстиції України // Офіційне видання. - К., 2006.

5. Про адвокатуру і адвокатську діяльність : Закон України // Відомості Верховної Ради України (ВВР), 2013. - № 27. - С. 282.

6. Енциклопедія бізнесмена, економіста, менеджера. - К., Міжнародна економічна енциклопедія, 2000. - С. 360 (703с.). 


\title{
РЕФОРМА АДМІНІСТРАТИВНО-ТЕРИТОРІАЛЬНОГО УСТРОЮ УКРАÏHCЬKОÏ СРP 1930 РОКУ ТА ÏIї ВПЛИВ НА ЖИТТЯ НАЦІОНАЛЬНИХ МЕНШИН
}

\author{
КУЗЬМЕНКО Наталя Олексіївна - провідний науковий співробітник \\ відділу європейського права та міжнародної інтеграції Інституту законодавства \\ Верховної Ради України
}

ORCID iD: https://orcid.org/0000-0002-8926-498X DOI 10.32782/LAW.2020.3.2

\section{Постановка проблеми}

Нині в Україні реалізується реформа адміністративно-територіального устрою, сутність якої полягає у децентралізації влади, у тому числі й передачі від органів виконавчої влади органам місцевого самоврядування значної частини повноважень, матеріальних ресурсів та відповідальності. В основу цієї реформи було закладено як положення Європейської хартії місцевого самоврядування, так і найкращі світові стандарти у сфері управління територіальними громадами. Разом з тим у процесі реалізації реформи значною мірою актуалізуються питання власного історичного досвіду реформування адміністративно-територіальної системи, зокрема й впливу такого реформування на життя окремих національних груп України. Зважаючи на це, дослідження впливу адміністративно-територіальної реформи 1930 року на життя національних меншин України набуває особливої актуальності.

\section{Стан дослідження проблеми}

Слід зазначити, що питання історії адміністративно-територіального реформування України вже певною мірою досліджувалися вітчизняними та зарубіжними науковцями, зокрема, О.В. Антонюк, О.Ю. Борисьонок, Я.В. Верменич, Р.В. Губанем, Г.Г. Ефіменком, О.А. Копиленком, В.С. Макарчуком, ᄉ.I. Рябошапком, I.М. Скуратович, І.Б. Усенком, Б.В. Чирком, О.Н. Ярмишом та ін. Водночас проблеми впливу адміністративно-територіальної реформи 1930 року на суспільно-політичне, соціально-економічне та культурно-національне життя національних меншин України на сьогодні з'ясовані ще недостатньо та потребують поглибленого наукового осмислення.

Мета і завдання дослідження

Відтак, метою статті є системне дослідження впливу адміністративно-територіальної реформи 1930 року на життя національних меншин Української СРР.

Виклад основного матеріалу

Наприкінці 1920-х років керівництво Радянського Союзу остаточно відмовилося від «нової економічної політики», розпочавши докорінну перебудову держави, що отримала назву «радянська модернізація». Ïї складовими стали індустріалізація, колективізація та «культурна революція», що супроводжувалися масовими політичними репресіями. Реалізація цієї політики сприяла формуванню системи повного (тотального) контролю держави і партії над усіма сферами суспільного життя, утвердженню тоталітаризму. Усе це вимагало певної реорганізації чинної системи управління в державі, у тому числі й внесення істотних змін до чинної на той час системи адміністративно-територіального устрою держави.

Слід зазначити, що наприкінці 1920-х років в Українській СРР була сформована та успішно функціонувала триступенева система управління із відповідним адміністративно-територіальним поділом. Так, відпо- 
відно до постанови ВУЦВК від 12 квітня 1923 р. «Про новий адміністративно-територіальний поділ України» замість чинних 102 повітів, які ділилися на 1989 волостей, було утворено 53 округи, що складалися із 706 районів. Крім того, було зменшено також і кількість сільських рад з 15696 до 9307. Разом з тим згідно з Постановою ВУЦВК від 3 червня 1925 р. «Про ліквідацію губерень й про перехід на трьохступеневу систему управління» було ліквідовано губернську ланку управління, а також дещо скорочено кількість округ УСРР [1]. Загалом наприкінці 1925 р. у складі Української СРР перебували: Автономна Молдавська СРР (створена 1924 р.), 41 округ, 680 районів, 10314 сільрад, 70 міських і 155 селищних рад. Таким чином, на середину 1920-х рр. замість чинної чотирьохступеневої системи управління (центр - губернія - округ - район) була утверджена триступенева система управління (центр - округ - район).

Подальше реформування адміністративно-територіальної системи було ініційовано у квітні 1929 р. на XVI партійній конференції ВКП(б). Зокрема, у відповідній резолюції цієї конференції ставилося завдання: «Піддати спеціальному вивченню підсумки районування, насамперед, 3 точки зору наближення апарату державного управління до мас робітників і працюючих селян. Оскільки вузловим пунктом, де реалізуються директиви партії і радянської влади, є район, сюди необхідно перенести центр ваги роботи із покращення і виправлення державного апарату. У відповідності з цим повинна бути переглянута структура окружного радянського апарату 3 точки зору забезпечення районних центрів якомога більшою кількістю перевірених комуністів, організаторів і спеціалістів» [2, с.653].

Згодом керівництво СРСР ухвалило рішення щодо створення низки дослідно-показових округів, яке було оформлено постановою ЦВК та РНК СРСР від 10 липня 1929 р. «Про дослідно-показові округи» [3]. Утворення цих експериментальних округів було покликано проаналізувати практику перенесення значної частини оперативних функцій, що виконували окружні органи державної влади, до районних органів та сільрад.

Відповідно до постанови ВУЦВК та РНК УСРР від 30 серпня 1929 р. «Про організацію спробно-показової округи» в Україні експериментальними було визначено Вінницьку та Зинов ївську округи [4]. Більшість функцій, що належали раніше окружним виконавчим комітетам вищезазначених округів, було передано райвиконкомам, міськрадам та сільрадам. За окрвиконкомами залишились переважно функції планування та здійснення контролю за роботою підпорядкованих органів. Водночас значна частина відділів окрвиконкомів була ліквідована, а натомість запроваджувалися відповідні нечисельні інспекції або окремі інспектори, що підпорядковувались безпосередньо голові окрвиконкому та підтримували тісний зв'язок із районними органами влади та сільрадами. При цьому всі працівники, що вивільнялися, спрямовувалися на роботу до районних органів влади та сільських рад.

Слід зазначити, що експеримент із перерозподілом функцій органів державної влади, а також відповідальних працівників між округом та районами був визнаний вдалим. Більше того, як зазначає вітчизняний дослідник Р.В. Губань, робота експериментальних округів виявилася значно ефективнішою, оскільки тепер округи змогли зосередитися на вирішенні стратегічних завдань та більше уваги приділяти плануванню [5, с.120]. Відтак, за результатами цього експерименту українське партійно-державне керівництво виявило ініціативу подальшого вдосконалення чинної адміністративно-територіальної системи республіки, зокрема й щодо скорочення кількості округів.

3 метою подальшого вдосконалення чинної адміністративно-територіальної системи, у тому числі щодо скорочення витрат на утримання управлінського апарату, а також поліпшення економічного стану округів та районів 13 червня 1930 р. ВУЦВК і РНК УСРР видали постанову «Про реорганізацію округів УСРР», відповідно до якої було розформовано такі округи: Кам'янецький, Шепетівський, Коростенський, Ніжинський, Глухівський, Прилуцький, Ізюмський, Куп'янський, Старобільський, Тульчин- 


\section{Теорія, історія держави і права, конституційне право}

ський, Первомайський, Роменський, Могилівський [6]. Території ліквідованих округів приєднувались до інших, а працівники управлінських апаратів спрямовувались на посилення районних органів влади та сільрад.

Втім, на етапі утвердження тоталітаризму, стратегія і тактика адміністративнотериторіального реформування республіки визначалася вже на загальносоюзному рівні. Так, 15 червня 1930 р. за ініціативою Й.В. Сталіна на засіданні Політбюро ЦК ВКП(б) було розглянуто питання адміністративно-територіальної реформи та визнано «необхідним скасування округів і максимальне посилення районних організацій за рахунок працівників окружних організацій, що вивільняються, із встановленням безпосереднього зв’язку обкомів (крайкомів, національних ЦК) з районними організаціями» [7, арк.3].

Питання про необхідність ліквідації округів обговорювалося також на XVI з'їді ВКП(б). Так, 27 червня 1930 р. Й.В. Сталін, виступаючи із політичним звітом ЦК ВКП(б), у черговий раз наголосив, що необхідно «наблизити партійно-радянський апарат до району і села для того, щоб отримати можливість своєчасно вирішувати наболілі питання сільського господарства, його підйому, його реконструкції». Торкаючись питань розвитку колективізації, він підкреслював, що «нині центр ваги колгоспного будівництва зміщений до районних організацій», і тому необхідно посилити райони «достатньою кількістю потрібних працівників». Для досягнення цієї мети Сталін пропонував скасувати округи, а за рахунок вивільнених окружних працівників посилити районні організації та пов'язати районні організації безпосередньо з областю (крайкомами, національними ЦК). При цьому Сталін зробив застереження, що ліквідацію округ необхідно проводити не відразу, а лише після проведення відповідної підготовчої роботи [8, с.45].

3 метою обговорення практичних питань, пов'язаних із ліквідацією округів, 11 липня 1930 р. було скликано спеціальну нараду Комісії ЦКК ВКП(б) і делегатів XVI з“ізду ВКП(б) (представників союзних республік, країв і областей). На цій нараді було обговорено питання підготовки, особливості реалізації, а також визначено терміни ії проведення - до 1 січня 1931 р. Проте, через чотири дні, 15 липня 1930 р. Політбюро ЦК ВКП(б) за ініціативою Сталіна ухвалюе нову постанову "Про ліквідацію округ», відповідно до якої усі підготовчі роботи 3 ліквідації окружної ланки управління зобов'язувалось розпочати негайно та завершити їх у стислий термін [9, арк.10-11]. Такому поспіху у проведенні цієї реформи є досить просте та логічне пояснення: адже для окружного партійного i радянського апарату питання ліквідації округів було питання їх подальшої долі. Як справедливо зазначає О.П. Воробей, «можна лише уявити собі, який шок пережили сотні окружних чиновників, дізнавшись, що більшості з них доведеться покинути насиджені міські посади і переміститися до необлаштованої глушини районів» $[10$, с.90].

Вищезазначене рішення Політбюро ВКП(б) було оформлене у радянському порядку спільною постановою ЦВК СРСР і РНК СРСР від 23 липня 1930 р. «Про ліквідацію округів». Згідно з цією постановою ліквідація окружних органів влади повинна бути завершена до 1 жовтня 1930 р. Постановою також передбачалося, що усі матеріальні ресурси, бюджетні кошти, підприємства, соціально-культурні заклади та цінності, які були у розпорядженні окружних органів влади, передавалися до районів. Водночас не менш як $90 \%$ усіх колишніх відповідальних працівників округів направлялися до районів. При чому, норма 90 \%, згідно з подальшим спеціальним роз'ясненням ЦК ВКП(б), стосувалася насамперед керівних окружних кадрів. Разом з тим районні виконавчі комітети наділялися правами та обов'язками, якими за чинним законодавством володіли раніше окрвиконкоми. Крім того, крайовим (обласним) та республіканським органам влади наказувалося встановити безпосередній зв'язок із районними органами влади.У постанові також спеціально застерігалося, що в процесі адміністративно-територіального реформування чинна мережа національних сільрад та районів повинна бути збережена у повному обсязі [11]. 
Реалізація визначених загальносоюзною постановою завдань на республіканському рівні була детальніше регламентована постановою ВУЦВК та РНК від 02 вересня 1930 р. «Про ліквідацію округ та перехід на двоступеневу систему управління» [12]. Згідно з цією постановою в Україні з 15 вересня 1930 р. усі округи ліквідовувалися, а територія республіки розподілялася на 503 адміністративно-територіальні одиниці: 484 райони, 18 міст республіканського підпорядкування і Автономна Молдавська СРР (до складу якої входили 11 районів).

Разом 3 тим зростання адміністративно-політичного значення районів, укріплення їх матеріальної бази, розширення обсягу прав та обов'язків районних органів влади обумовило необхідність докорінної перебудови організаційної структури та штатного розпису районних виконавчих комітетів. Ця перебудова була закріплена постановами президії ЦВК СРСР від 9 серпня 1930 р. «Про структуру і типові орієнтовні штати районних виконавчих комітетів» [13] та від 21 серпня 1930 р. «Про зміни і доповнення постанови Президії Центрального Виконавчого Комітету Союзу РСР від 9 серпня 1930 р. «Про структуру і типові орієнтовні штати районних виконавчих комітетів» [14], а також затвердженими ЦВК та РНК СРСР 20 жовтня 1930 р. «Основними положеннями про районні з'їди рад і районних виконавчих комітетів» [15].

Згодом основні положення вищевказаних загальносоюзних постанов знайшли своє відображення у відповідних республіканських нормативно-правових актах. Так, у новому типовому штатному розписі районних виконавчих комітетів передбачалися наступні відділи: загальний, земельний, фінансовий, адміністративний, плановостатистична частина i робітничо-селянська інспекція. Водночас під безпосереднім керівництвом президії райвиконкому дозволялося також запроваджувати посади інструкторів: по роботі із жінками, по військових справах, по роботі з національними меншинами та ін. Разом $з$ тим новий штатний розпис районних органів влади вже не передбачав створення спеціальних комісій 3 українізації, що раніше функціонували при окружних і районних виконкомах.

Крім того, у новій структурі райвиконкомів не знайшлося місця для формування так званих бюро нацменшин, які раніше в обов'язковому порядку функціонували при окружних виконкомах. Натомість, тепер у районах, де компактно мешкали представники національних меншин, дозволялося лише запроваджувати посади націнструкторів. Так, зокрема, внаслідок адміністративно-територіальної реформи 1930 р. із 12 колишніх співробітників Сталінського округового бюро національних меншин на місці залишилося лише п'ятеро осіб, причому лише один із них обійняв посаду національного інспектора Сталінського райвиконкому. Інші сім співробітників отримали нові призначення до районів колишньої округи [16, арк.16].

Разом 3 тим відсутність у новому штатному розписі райвиконкомів спеціально визначених працівників по роботі з представниками національних меншин неминуче призводила послаблення уваги органів державної влади до вирішення нагальних проблем представників національних меншин та, як наслідок, зростання міжнаціонального напруження в регіонах. Як зазначав у своїй доповідній записці до ЦК КП(б)У голова ЦКНМ М. Василенко: «Теперішній стан на місцях якщо його не буде змінено, без сумніву приведе до різкого зниження рівня роботи серед національних меншин. У той же час ряд процесів, що помічаються серед нацменшин (еміграційні настрої серед німців, тяжіння німців до переселення з українських до німецьких сіл та районів; події, що мали місце в болгарському Вільшанському районі тощо), усе це вимагає посилення уваги нацменроботі» [17, арк.11-12].

3 метою налагодження системної роботи 3 представниками національних меншин та впорядкування мережі місцевих органів Центральної комісії національних меншин президія ВУЦВК 15 січня 1931 р. ухвалила постанову «Про заведення до штатів деяких райвиконкомів посад інструкторів по роботі серед національних меншин». Відповідно до цієї постанови штатні посади інструкторів для роботи серед національних меншин 


\section{Теорія, історія держави і права, конституційне право}

запроваджувалися у тих районах, де національні меншини становили понад $10 \%$ населення. Загалом на початок 1931 р. у районах компактного проживання національних меншин було введено 110 штатних посад нацменінструкторів, з яких 41 - по єврейській лінії, 34 - по польській, 16 - по російській. На середину 1930-х років їх кількість зросла до 130 [18, с.60].

Разом $з$ тим в Українській СРР ще на початку 1930 р. було ліквідовано також національні секції при партійних комітетах. Так, у постанові Секретаріату ЦК КП(б)У від 11 лютого 1930 р. зазначалося: «Визнати за можливе ліквідувати в ЦК та ОПК сектори та бюро нацменшостей, зобов'язавши всі відділи (особливо культурно-проп. агітаційно-масовий) розгорнути роботу серед нацменшостей. Фракціям ВУЦВК та НКО розробити питання про покращення культурного обслуговування нацменшостей» [19, арк.96]. Реалізація цієї постанови мала суттєві негативні наслідки, про які вже у липні 1930 р. повідомлялося у доповідній записці відділу культури і пропаганди при ЦК КП(б)У «Про стан роботи серед нацменшостей», яка була розглянута на засіданні Секретаріату ЦК КП(б)У. У ній, зокрема, наголошувалося, що у зв'язку з ліквідацією нацсекторів «у більшості округів робота серед нацменшостей по радянській лінії не тільки не посилилась, але помітно ослабла» [20, арк.21]. Більше того, у деяких округах, де раніше були окремі нацменпрацівники і по партійній і по радянській лінії, після реорганізації не лишилось жодного. Так сталося, наприклад, на території колишньої Одеської округи.

Крім того, внаслідок адміністративно-територіальної реформи 1930 р. було безпосередньо ліквідовано деякі національні райони та сільради. Зокрема, було розформовано Хортицький німецький національний район, який приєднали до Запорізької міської ради; об'єднано російські Петропавлівський та Станично-Ауганський райони та створено на їх основі Верхньо-Теплівський; ліквідовано Ботіївський болгарський район із включення його території до Коларівського болгарського району [12].

\section{Висновки}

Отже, реалізація адміністративно-територіальної реформи 1930 р. в умовах утвердження тоталітарного режиму в СРСР призвела до істотних негативних наслідків у забезпеченні прав національних меншин. У процесі цієї реформи було реорганізовано деякі національні райони та сільради, ліквідовано значну кількість посад в органах державної влади, які покликані були сприяти налагодженню міжнаціонального спілкування в республіці та більш активному залученню представників національних меншин до суспільно-політичного та національно-культурного життя країни. Таким чином, порушення внаслідок адміністративно-територіальної реформи 1930 р. налагодженої упродовж 1920-х років спеціальної системи органів влади, яка була покликана опікуватися соціально-економічними та соціально-культурними проблемами національних меншин України, призвело до зростання міжнаціонального напруження, викликало недовіру національних меншин до рішень та заходів органів державної влади, сприяло порушенню міжнаціональних зв'язків населення Української СРР.

\section{Аітература}

1. Постанова ВУЦВК від 3 червня 1925 р. «Про ліквідацію губерень й про перехід на трьохступеневу систему управління» // Збірник узаконень та розпоряджень робітничо-селянського уряду України (далі - 33 УСРР). 1925. №29-30. Ст.233.

2. Шестнадцатая конференция ВКП(б). Апрель 1929 года. Стенографический отчет. М.: Госполитиздат, 1962. 837 с.

3. Постановление ЦИК та СНК СССР от 10 июля 1929 г. «Об опытно-показательных округах» // Собрание законов и распоряжений рабоче-крестьянского правительства Союза Советских Социалистических Республик (далее - С3 СССР). 1929. №45. Ст.389.

4. Постанова ВУЦВК та РНК УСРР від 30 серпня 1929 р. «Про організацію спробно-показової округи» // 33 УСРР. 1929. №24. Ст.190.

5. Губань Р.В. Становлення та розвиток адміністративно-територіального устрою України в XX - на початку XXI століття (ic- 
торико-правове дослідження): дис. ... д.ю.н.: 12.00.01 / Національний педагогічний університет імені М.П. Драгоманова. К.,2018. $-601 \mathrm{c}$.

6. Постанова ВУЦВК і РНК УСРР від 13 червня 1930 р. «Про реорганізацію округ УСРР» // 33 УСРР. 1930. №14. Ст.141.

7. Российский государственный архив социально-политической истории (далее РГАСПИ). Ф.17. Оп.3. Спр.787. Арк.3.

8. Шестнадцатый съезд ВКП(б). 26 июня - 13 июля 1930 г. Стенографический отчет. В 2-х тт. М.; Партиздат, 1935. Т.1. $717 \mathrm{c}$.

9. РГАСПИ. Ф.17. ОП.3. Спр.789. Арк.10-11.

10. Воробей А.П. Влияние структурной перестройки органов ВКП(б) на ход и результаты коллективизации в Северном крае, 1929-1930 годы: дисс. ... канд. ист. наук. Архангельск, 1999. 231 с.

11. Постановление ЦИК и СНК СССР от 23 июля 1930 г. «О ликвидации округов» // C3 CСCP. 1930. №37. Ст.400.

12. Постанова ВУЦВК та РНК від 02 вересня 1930 р. «Про ліквідацію округ та перехід на двоступеневу систему управління» // 33 УСРР. 1930. №23. Ст.225.

13. Постановление Президиума ЦИК СССР от 8 августа 1930 г. «О структуре и типовых ориентировочных штатах районных исполнительных комитетов» // C3 CССР. 1930. №42. Ст.433.

14. Постановление Президиума ЦИК СССР от 21 августа 1930 г. «Об изменениях и дополнениях постановления Президиума ЦИК СССР от 9 августа 1930 г. «О структуре и типовых ориентировочных штатах районных исполнительных комитетов» // С3 CССР. 1930. №42. Ст.434.

15. Постановление ЦИК и СНК СССР от 20 октября 1930 г. «Основные положения о районных съездах советов и районных исполнительных комитетах» // С3 СССР. 1930. №52. Ст.545.

16. Центральний державний архів вищих органів влади та управління України (далі - ЦДАВО України). Ф.413. Оп.1. Спр.488. Арк.16.

17. ЦДАВО України. Ф.413. Оп.1. Спр.511. Арк.11-12.
18. Балуба I.А. Польська національна меншина України в 20-30 pp. ХХ ст.: Дис. ... канд. іст. наук: 07.00.01. К., 1997. 222 с.

19. Центральний державний архів громадських об'єднань України (далі - ЦДАГО України). Ф.1. Оп.7. Спр.139. Арк.96.

20. ЦДАГО України. Ф.1. Оп.7. Спр.150. Арк.21.

\section{REFORM OF THE ADMINISTRATIVE- TERRITORIAL ORGANIZATION OF THE UKRAINIAN SRR IN 1930 AND ITS INFLUENCE ON THE LIVES OF NATIONAL MINORITIES}

The article considers the reform of the administrative-territorial structure of the Ukrainian SSR in 1930 and its impact on the lives of national minorities. It was found that in the second half of the 1920s in the Ukrainian SSR was formed a proper organizational and legal framework for the formation and functioning of national districts and village councils, an important role in the management system which was played by the district. The formation of national districts and village councils, land management in places of compact residence of national minorities, creation of national educational and cultural institutions, providing opportunities for communication between representatives of national minorities and state authorities in their native language was a historically progressive step by the Soviet government. increasing the level of their political activity and culture.

It is established that at the stage of the establishment of totalitarianism the initiative, strategy and tactics of further administrativeterritorial reform of the republic were already determined at the all-Union level. The implementation of the administrative-territorial reform of 1930 led to the liquidation of the district administration and, as a consequence, to the breakdown of the special system of government established during the 1920s, which took care of socio-economic and socio-cultural problems of national minorities. At the same time, some national districts and village councils were liquidated in the reform process. All this led to the partial loss of communication channels of state authorities and representatives of 


\section{Теорія, історія держави і права, конституційне право}

\section{АНОТАЦІЯ}

у статті розглянуто реборму адміністративно-територіального устрою Украӥнсъкой СРР 1930 року та ї̈ вплив на життя національних меншин. З'ясовано, що в процесі ребормування поряд зі скасуванням в Україні окружної ланки управління було розбормовано частину національних районів та сільрад, а також ліквідовано низку спеціальних органів державної влади, що опікувалися проблемами національних меншин. Встановлено, що реалізаиія реборми 1930 р. в умовах утвердження тоталітарного режиму в СРСР призвела до істотних негативних наслідків у забезпеченні прав національних меншин.

Ключові слова: адміністративно-територіальна реборма, окружна ланка управління, національні райони та сільради, національні меншини, утвердження тоталітарного режиму. national minorities, caused their distrust of the decisions and measures of the Soviet government, contributed to the disruption of established interethnic ties of the population, led to growing ethnic tensions in Ukraine.

It is proved that the implementation of the reform of 1930 in the conditions of the establishment of the totalitarian regime in the USSR led to significant negative consequences in ensuring the rights of national minorities. The necessity of taking into account the national factor in the process of administrative-territorial reform is substantiated.

Key words: administrative-territorial reform, district administration, national districts and village councils, national minorities, establishment of a totalitarian regime. 


\title{
ПОЛІЦЕЙСЬКА ОСВІТА: СВРОПЕЙСЬКІ ПІДХОДИ ДО ОРГАНІЗАЦІї ТА ТЕНДЕНЦІї РОЗВИТКУ
}

\author{
ШВЕЦЬ Дмитро Володимирович - доктор юридичних наук, доценТ, ректор \\ Харківського національного університету внутрішніх справ \\ ORCID: http:// orcid.org/0000-0002-1999-9956 \\ СВДОКІМОВА Олена Олександрівна - доктор психологічних наук, \\ професор, Харківський національний університет внутрішніх справ \\ ORCID: http://orcid.org/0000-0003-4211-7277 \\ УДК 159.9 \\ DOI 10.32782/LAW.2020.3.3
}

\begin{abstract}
В статье исследованъ европейские подходъ к подготовке кадров для полиции. Показано, что они детерминируются рядом факторов, таких как: государственная политика, идеология и сочиальнъе установки; начионально-исторические традиции; образовательнъе кониепции, идеи и принципъ, специфика национальнъхх правовых систем; особенности организации и регулирования деятельности правоохранительных органов и тому подобное. Отмечено, что тенденциями развития систем подготовки полицейских в европейских странах можно считать усиление их кооперации, унификации национальных законодательств, активная направленность на сотрудничество с населением и увеличение в программах подготовки доли сочиально-поведенческих наук.

Ключевъе слова: полицейское образование, общество, программв подготовки, законодательство, правоохранительные структурь, правовая система
\end{abstract}

\section{Постановка проблеми}

Сучасна система підготовки кадрів має на меті готувати поліцейських професіоналів будь-якого рангу для виконання різноманітних державних завдань у правоохоронній сфері. У контексті багатьох резонансних подій, пов'язаних з діяльністю поліції та інших правоохоронних підрозділів України, питання щодо рівня професійної та освітньої підготовки правоохоронців, їх здатності до взаємодії та співпраці з громад- ськістю набули надзвичайної актуальності. У суспільстві широко дискутуються різні точки зору на хід поліцейської реформи, у зв'язку з цим аналіз багаторічного досвіду підготовки правоохоронців в європейських країнах набуває особливого значення.

Стан дослідження проблеми

Проблеми професійної підготовки та освіти правоохоронців постійно привертають увагу науковців: як юристів і психологів, так учених й інших галузей знання, зокрема педагогіки, соціології, кримінології, криміналістики, оперативно-розшукової діяльності, теорії управління та низки інших наук. 3 урахуванням міждисциплінарного характеру зазначеної проблеми, науковому аналізу тих чи інших ії аспектів присвячені праці, зокрема, В. Авер'янова, В. Андросюка, О. Бандурки, В. Барка, В. Бесчастного, М. Вербенського, О. Евдокімової, А. Журавльова, О. Землянської, М. Іншина, З. Кісіль, I. Клименка, О. Колесник, М. Костицького, Т. Кочетової, В. Кудрявцева, О. Аитвинова, В. Ауньова, С. Максименка, О. Малиновського, Г. Матусовського, В. Медведєва, В. Менделевича, О. Музичука, В. Мясіщева, I. Охріменка, С. Пенькова, М. Пихтіна, Я. Посохової, В. Сокуренка, Х. Стивенса, В. Тація, О. Тімченка, А. Ухтомського, О. Федоренко, Д. Форда, О. Цільмак, В. Чернєя, Д Швеця, О. Ярмиша та інших.

У зарубіжних дослідженнях широко дискутуються питання щодо необхідного рівня освіти для працівників поліції. Европейські 


\section{Адміністративне право}

дослідники Т. Фелтес [2, р. 48-59] і Р. Піс [3, р. 335-346] підкреслюють важливість концептуалізації вимог до поліцейського та вказують на те, що моделі поліцейської освіти повинні містити чіткі цілі, суспільноорієнтований зміст навчальних програм i відповідний метод, щоб полегшити перехід від правоохоронної діяльності до співпраці 3 громадськістю.

Поліція в демократичних суспільствах існує в політичному вимірі, де визнається важливість соціальної справедливості, соціальної згуртованості, чесності, рівності та прав людини. Д. Бейлі й Е. Біттнер стверджують, що цим цінностям можна навчити поліцейських [4, p. 44].

Р. Роберг зазначає, що саме освіта (а не підготовка) є необхідною для розвитку цих цінностей і ефективним $є$ використання розмежування цих понять, яке підтримує та підвищує продуктивність працівників поліції, відповідальність і професіоналізм [5, p. 469-486].

Взаємостосунки між вищою освітою та правоохоронною діяльністю, засновані на фактичних даних, констатує $\lambda$. Шерман, забезпечують платформу для визначення того, що є головним завданням поліції та як це завдання вирішувати, а також які переваги брати до уваги [6].

\section{Мета і завдання дослідження}

Метою статті став аналіз результатів реформування систем підготовки поліцейських кадрів у зарубіжних країнах у контексті можливості подальшого використання вже набутого досвіду реорганізації поліцейської освіти та запобігання помилок. Автори поставили собі за мету розкрити основні особливості підготовки правоохоронців у європейських країнах у ракурсі історичних, економічних, соціальних, організаційних чинників.

\section{Наукова новизна дослідження}

Уперше європейські підходи до підготовки кадрів для поліції досліджено у контексті як правових, так і соціально-психологічних аспектів. Показано, що вони детермінуються низкою чинників, таких як: державна політика, ідеологія і соціальні настановлення; національно-історичні традиції; освітні концепції, ідеї та принципи; специфіка національних правових систем; особливості організації та регулювання діяльності правоохоронних органів тощо.

\section{Виклад основного матеріалу}

У більшості європейських країн системи професійної поліцейської освіти не є замкнутими, вони взаємодіють і інтегруються iз загальними (цивільними) національними освітніми системами, головне завдання яких полягає в тому, щоб встановити належний баланс між ними, адекватний реальним умовам кожної європейської країни, а також тим державним завданням, які стоять перед ії правоохоронною системою $[7$, c. 9$]$.

Особливістю системи підготовки працівників правоохоронних органів європейських країн $\epsilon$ їх тісна міжнародна кооперація. Ще у 90-х роках минулого століття була створена інтегрована система професійної підготовки працівників правоохоронних органів на основі єдиних європейських стандартів освіти у правоохоронній діяльності. Сучасна професійна освіта у право-/ охоронній сфері запроваджена у Німеччині, Норвегії, Бельгії (жандармерія), Греції, Фінляндії, Польщі, Угорщині, Словаччині, Чехії, Україні, Хорватії і Словенії тощо. Підготовка в цих країнах здійснюється в освітніх закладах, які знаходяться у підпорядкуванні поліції або Міністерств внутрішніх справ. У Словенії коледж поліції $\epsilon$ як частиною Міністерства внутрішніх справ, так і філіалом цивільного університету у м. Аюбляни. Централізоване підпорядкування університету, безсумнівно, сприяло підвищенню науково-освітнього та соціального престижу коледжу.

Сьогодні, щоб вступити до закладу, який пропонує вищу професійну поліцейську освіту, студенти в Норвегії, Угорщині, Чехії, Словенії не обов'язково повинні перебувати на службі в правоохоронній системі. У той час, як в інших країнах Європи, студенти вищого навчального закладу, які отримують освіту для правоохоронної системи, 
повинні мати стосунок до цієї структури.У семи європейських країнах (Норвегії, Бельгії, Греції, Польщі, Угорщині, Чехії і Словенії) студентам (курсантам) не обов'язково мати досвід роботи в поліції до вступу до навчального закладу. В інших країнах від студентів вимагають принаймні два роки досвіду практичної роботи в поліції. У Німеччині працівник поліції може здобути вищу професійну освіту в навчальних закладах освіти («Fachhochschulen») для адміністрації. У Хорватії, Німеччині, Угорщині, Нідерландах, Словаччині курсанти (слухачі) зобов'язані стати працівниками поліції, як тільки їх буде зараховано до школи поліції. У семи країнах (Хорватія, Чеська Республіка, Фінляндія, Німеччина, Македонія, Словаччина і Словенія) заклади вищої освіти перебувають у підпорядкуванні поліції. В Угорщині школа поліції не є частиною поліції, але пропонує поліції навчальні програми. У Нідерландах школи поліції знаходяться у підпорядкуванні окремих інститутів, що фінансуються урядом.

Сучасна європейська стратегія підготовки кадрів правоохоронних структур залежить від цілого ряду факторів, таких як: державна політика, ідеологія і соціальні погляди в тій чи іншій країні; національно-історичні традиції; особливості військової та правоохоронної сфери діяльності держави; освітні концепції, ідеї та принципи; національна правова система; призначення, організація та регулювання діяльності правоохоронних органів; національні особливості системи професійної підготовки співробітників правоохоронних органів, інноваційні проєкти в галузі кадрового менеджменту; соціально-економічні та управлінські теорії зі сфери державного управління [8, с. 272].

Европейська система підготовки управлінських кадрів у правоохоронній сфері представляє собою три концептуальні рівні: нижній, середній та вищий. На кожному рівні передбачається поступове нарощування і ускладнення знань, навиків і практичних навичок під час переміщення по службі, виходячи зі службових обов'язків кандидата на певну посаду. Особливістю процесу підготовки кадрового резерву є той факт, що всі кандидати на посади в правоохоронних органах, незалежно від їх вченого звання, досвіду роботи в правоохоронній сфері і наявного спеціального рангу у відповідній ієрархії, проходять відповідне професійне навчання (перепідготовку), тривалість і зміст яких обумовлені кар'єрним вимогам.

Кандидати на заміщення певної посади проходять той або інший вид підготовки кадрів у поліцейській академії, навчальних центрах або в інших відомчих навчальних закладах за освітніми програмами відповідної фахової спрямованості. Слід зазначити, що в більшості європейських країн системи професійної поліцейської освіти не є замкнутими, а взаємодіють і інтегруються iз загальними (цивільними) національними освітніми системами, головне завдання яких полягає в тому, щоб встановити належний баланс між ними, адекватний реальним умовам кожної європейської країни, а також тим державним завданням, які ставляться перед їі правоохоронною системою [9].

У європейських країнах систему державного управління у сфері освіти щодо підготовки персоналу для правоохоронних органів формують загальнонаціональні закони про поліцію, декрети і укази глав держав і керівників виконавчої влади, а також нормативні акти органів місцевого самоврядування, які містять положення про правовий режим окремих категорій поліцейського персоналу. Крім того, правова регламентація професійної підготовки кадрів у правоохоронній сфері знаходить відображення у відомчих нормативно-правових актах загальнонаціонального рівня, регіонального (територіального) і місцевого (муніципального) рівнів залежно від підвідомчості освітньої установи, яка провадить професійну підготовку, а також посадового та кваліфікаційного рівня кадрів, для яких вона призначена.

Міждержавна співпраця у правоохоронній сфері здійснюється у форматі міждержавних нормативно-правових актів, таких як «Угода про єдину освіту кандидатів для вищих органів поліцейської виконавчої служби EС», «Угода про поліцейську акаде- 


\section{Адміністративне право}

мію управління $\mathrm{EC»} \mathrm{та} \mathrm{інших} \mathrm{міжнародних}$ договорів.

Вивчення особливостей організації професійної підготовки поліцейських в європейських країнах показує високий ступінь нормативно-правової регламентації всіх етапів цього процесу, починаючи з підбору кандидатів на висунення та формування кадрового резерву або на призначення на керівну посаду і закінчуючи етапом оцінювання якості навчання та практики реалізації змісту навчання.

Формування кадрового резерву кандидатів на посади в правоохоронній сфеpi неможливе без всебічної професійної підготовки, яка $\epsilon$ необхідною умовою для просування на керівні посади в кожній 3 європейських країн. Найбільш загальні навчальні теми підготовки управлінських кадрів у правоохоронній сфері є в Нідерландах, що включають: розробку профілактичних правоохоронних операцій; навчання для модульної освіти та розвиток кар'єри; питання мотивацій поліцейської діяльності та управління фінансами; управління проєктами та ефективна тактика впливу.

У Німеччині законодавчі основи професійної діяльності поліції, у тому числі організаційно-правові основи підготовки професійних кадрів, які тісно пов'язані 3 нормативно-правовим регулюванням самої діяльності поліції були розроблені ще в XIX сторіччі. Сьогодні основою всієї поліцейської діяльності в Німеччині є норми Основного Закону - Конституції ФРН від 23 травня 1949 року, які є основоположними при вирішенні поліцейських завдань та їх професійної підготовки. Ці положення розвиваються і конкретизуються у федеральних законах «Про поліцію» «Про співробітництво», а також законах федеральних земель «Про поліцію». Поряд з Конституцією та державними законодавчими актами, підготовка кадрів поліції в Німеччині регулюється законами кожної з шістнадцяти федеральних земель і положеннями про поліцію місцевих органів. Наприклад, у Баварії прийняті регіональні нормативно-правові акти: «Положення про проходження служби поліцейськими чиновниками землі
Баварія», «Положення про навчання поліцейських чиновників Баварії», «Положення про іспити для поліцейських чиновників Баварії» [10].

Поліція ФРН працює в складі Міністерства внутрішніх справ, яке має компетенцію, значно ширшу від МВС інших країн, i фактично контролюе всі сфери внутрішнього життя країни. У відповідності з цим побудована і національна система підготовки кадрів поліції у ФРН [10].

Організаційна структура поліції відображає адміністративно-територіальний устрій ФРН, обумовлена його федеративною формою. У поліцейській системі виділяють федеральний і земельний рівні, а також муніципальні органи загальної безпеки. Таким чином поліцейська система Нiмеччини належить до напівцентралізованого типу управління.

Найважливішою ланкою федеральної поліції є федеральна кримінальна поліція. Федеральне відомство по кримінальних справах (Bundeskriminalamt- BKA) як спільна служба федерації і земель була створена на основі Закону «Про створення федерального відомства по кримінальних справах», що вступив у силу 15 березня 1951 р. Співробітників Федерального відомства кримінальної поліції готує Федеральний коледж громадської адміністрації. Федеральне відомство також пропонує можливість проходження практики по десяти різних напрямax.

Поліція земель (Polizeider Bundeslдndern) є узагальнувальною дефініцією, що охоплює сукупність органів поліції суб'єктів Федерації, підпорядкованих безпосередньо міністрам внутрішніх справ земель (або сенаторам внутрішніх справ у містах Берлін, Гамбург і Бремен).

Органи поліцейського управління інтегровано до земельних систем державного управління. Вищою ланкою поліцейського управління земель вважається Міністерство внутрішніх справ, очолюване міністром (сенатором). Середній управлінський щабель органів поліції більшості земель репрезентують урядові президії або окружні (районні) уряди. Нижчий рівень поліцей- 
ської управлінської драбини формується на рівні міст і районів (поліцейські президії, поліцейські дирекції, районні поліцейські органи). У територіальних громадах діють поліцейські дільниці з охорони правопорядку (головні поліцейські вахти (караули), поліцейські станції, пости тощо), на основі яких організовано повсякденну поліцейську службу. Керівні фахівці для органів поліції громадської безпеки та кримінальної поліції земельного або федерального рівня проходять навчання в академії підготовки командного складу (Polizeifьhrungsakademie (PFA)), яка знаходиться в м. Мюнстер. 3 2006 р. академія, по суті, трансформована в університет поліції.

Специфіка підготовки у вищих професійних школах полягає в іiі цілеспрямованій орієнтації на вимоги практики. Для вищих професійних шкіл характерний тісний взаємозв'язок теоретичної і практичної підготовки. У ФРН підготовка рядових поліцейських здійснюється в рамках програм, складених Поліцейською академією. Тривалість курсу навчання поліцейського складає 2,5 роки. Перший рік присвячується вивченню основ теорії і практики поліцейської діяльності, за ним іде рік служби в чинних підрозділах під керівництвом досвідчених наставників, після цього - ще півроку теоретичного навчання, яке завершується іспитом на звання поліцейського.

Поліцейські школи мають хорошу навчальну базу і раціонально поєднують навчання теорії і іï закріплення практикою. На практичних заняттях майбутні поліцейські набувають різноманітні навики: від переслідування авто в міських і сільських умовах до стрільби по рухомих цілях. Особлива увага приділяється загальнофізичній підготовці, плаванню й заняттям різними видами спорту. До теоретичного курсу входить вивчення федеральних законів i законів окремих земель, процедур розслідування злочинів, основ регулювання транспорту, способів надання першої медичної допомоги, проблем взаємодії з населенням. Особливе місце відводиться на відпрацювання правильним методам втручання і затримання - від цього в основному залежить відношення до поліції в цілому, а також вивченню науки про поведінку людини [11,c. 72-77].

Після закінчення навчального закладу (школи, академії чи інституту поліції) для всіх службовців 6 обов'язковим проходження психологічних тренінгів як підвищення кваліфікації мінімум один раз на три роки. 3 цією метою співробітниками Інституту підвищення кваліфікації поліції Баварії розроблено тренінг «ПАКЕТ» - поліцейський антистресовий комунікативний тренінг, який проводиться протягом двох тижнів і має на меті не тільки оптимізувати психологічне вміння й навички, а й «лікувати душу». Таку концепцію проведення тренінгу обгрунтовують провідні фахівці ЦПС (центральна психологічна служба) поліції Баварії, які вважають, що службовці силових структур потребують психологічної допомоги та терапії більшою мірою, ніж працівники інших професій [12].

Незважаючи на унікальність поліцейських структур у різних федеральних землях, загальна організація поліцейських служб залишається більш-менш однаковою і представлена наступним чином: Земельне відомство кримінальної поліції (Landeskriminalamt). Займається питаннями забезпечення безпеки на земельному рівні, боротьбою з незаконним обігом зброї і вибухових речовин; розслідує особливо небезпечні злочини, пов'язані з незаконним обігом наркотичних засобів; веде боротьбу 3 організованою злочинністю; боротьбу 3 відмиванням грошових коштів; розслідує злочини, скоєні особами, які займають високе суспільне становище; розслідує справи, пов'язані $з$ викраденням культурних цінностей;виступає в ролі центрального органу, відповідального за організацію аналітичних досліджень, обробку даних, організацію спеціального навчання та підготовки, координує слідчі заходи.

У м. Бамберг (Баварія) знаходиться Президія баварської поліції готовності, де проводиться також підготовка майбутніх поліцейських, починаючи від вступних екзаменів до початку роботи в практичних підрозділах. У Баварії існує серйозна кон- 


\section{Адміністративне право}

куренція між навчальними закладами поліції та вузами економічної сфери, адже більшість випускників шкіл віддає перевагу економіці. Щоб привернути увагу молоді до роботи в силових структурах, у поліції ведуть активну роботу щодо заохочення особового складу до подальшого вступу у вищі навчальні заклади поліції, яких у Баварії є сім, у таких містах, як Мюнхен, Айхштет, Вюрцбург, Нюрнберг, Кьонігсбрунн, Дахау і Суро. Після закінчення навчального закладу у них є вибір - іти у поліцію чи у групу спеціального призначення. У Баварії також знаходяться два вищих навчальних заклади по підготовці поліцейських (Fachhochschule), які знаходяться в містах Фюрстенфельдбрук і Зульцбах-Розенберг. Кількість претендентів на здобуття поліцейської освіти сягає там біля 4000 осіб на рік [12].

У поліції Німеччини підготовка управлінських кадрів включає в себе такі навчальні теми, як боротьба зі злочинністю; безпека дорожнього руху; керування поліцейськими операціями; роль поліції в суспільстві; лідерство; розвиток людських ресурсів; законодавче забезпечення правоохоронної діяльності; міжнародне співробітництво. В Австрії, на додаток до перерахованих в Німеччині навчальних тем, відповідна програма включає в себе підбір персоналу; питання особистої безпеки i професійну риторику.

У Франції у прийнятому в 1985 р. Законі «Про реформування поліції» є спеціальний розділ, присвячений підготовці співробітників національної поліції всіх категорій i рангів. Зокрема, у Законі щодо підготовки керівних кадрів передбачається, що комісари поліції після отримання магістерського диплому в будь-якому університеті країн Европи повинні пройти курси прискореного поліцейського навчання у Вищій національній школі поліції Франції м. Аіон. Подальші директиви (1999р.) Міністра внутрішніх справ Франції конкретизували сутність організації професійної підготовки комісарів поліції трьох звань: комісарів, головних комісарів і дивізійних комісарів (близько 2000 штатних одиниць).
Системою підготовки вищих керівних кадрів у правоохоронній сфері в Бельгії надається значна увага питанням лідерства, ведення переговорів, комунікативних навичок та оперативного управління. На законодавчому рівні організована система федеральної та місцевої поліцейської служби Королівства Бельгія, визначено основні напрями спеціального навчання управлінських кадрів у правоохоронній сфері.

У Фінляндії найпоширеніші теми підготовки управлінців у правоохоронній сфері включають такі питання:

1) організація стратегічного, оперативного та тактичного управління;

2) управління персоналом та кадровий менеджмент, питання поліцейської етики;

3) технічні інновації у сфері обробки та захисту баз даних;

4) правова підготовка та міжнародне поліцейське право;

5) охорона громадського порядку та надання всебічної допомоги цивільним особам.

Особливості правоохоронної діяльності в умовах стресу, врегулювання конфліктних ситуацій та ефективне використання людських ресурсів 6 найбільш поширеними навчальними темами підготовки управлінських кадрів правоохоронних органів в Республіці Польща. У Польщі вища і післядипломна професійно-технічна освіти представлена в Вищій школі поліції у м. Щитно, яка готує висококваліфікованих співробітників поліції з адміністративного профілю.

Як відзначає О.А. Мартиненко, підготовка поліцейських починається з початкової професійної освіти, яка є обов'язковою. Цей етап навчання здійснюють визначені навчальні заклади з підготовки працівників поліції (Вища школа поліції у Щитно; навчальний центр поліції у Аегіоново; школи поліції у Катовіце, Слупську та Пілі) [13].

В Угорщині найбільш поширеними темами підготовки є питання розвитку та навчання персоналу, стратегії боротьби 3 організованою злочинністю, конституційні аспекти Кримінального кодексу, відносини між поліцією і засобами масової інформації, співпраця між органами місцевого самовря- 
дування та поліції, забезпечення громадської безпеки.

В Хорватії значна увага приділяється питанням наукового менеджменту, організаційного структурування, організаційної поведінки співробітників правоохоронних органів, управління конфліктами, прийняттю управлінських рішень. У Чеській Республіці найбільш поширені такі навчальні теми у підготовці поліцейських: управління людськими ресурсами; боротьби 3 організованою злочинністю; законодавче забезпечення правоохоронної діяльності; міжнародне співробітництво; аналітичні навички; попередження злочинності; управління поліцейськими операціями.

Реформування Державної поліції Італії розпочалося ще у 1981 р. після прийняття Закону № 121, який був спрямований на іiі демілітаризацію та гарантування забезпечення прав і свобод людини. Протягом декількох років уся система підготовки кадрів випереджала реструктуризацію поліції як у теоретичному плані, так і стосовно логістики та організації. Значні фінансові кошти були витрачені для забезпечення максимального комфорту в наявних та новостворених навчальних закладах. Італійські науковці, педагоги та практики доклали значних зусиль у сфері методології інноваційного навчання; наприклад, заходів, які успішно реалізуються у співробітництві з центральною дирекцією інститутів підвищення кваліфікації та університету у Венеції. Ці заходи стосуються теоретичних і практичних аспектів, методології й емпіричних досліджень у підготовці сучасних поліцейських. В Італії на цей час діють 34 школи 3 підготовки кадрів для поліцейських служб, які досить рівномірно розташовані по їі території. Сумарно вони розраховані на 8000 слухачів. Протягом п’яти років понад 80 тисяч поліцейських пройшли початкову підготовку та 15 тисяч співробітників - спеціальні курси.

Доволі специфічною є поліцейська освіта у Великобританії. Там процес професійної підготовки поліцейських $\boldsymbol{\epsilon}$ децентралізованим і здійснюється за регіональним принципом. Проте, з середини 80-х рр. в Англії проводяться заходи, спрямовані на посилення впливу центру на управління поліцією і підготовку для неї фахівців, оскільки однією 3 головних причин існування недоліків у підготовці кадрів і, відповідно, функціонуванні поліції є відсутність ефективного управління на національному рівні [15, с. 185-194].

У Великобританії головне завдання поліції - це служіння, у першу чергу, суспільству, громадянам, а вже потім - державі й уряду. Тому поліція, в цілому, користується повагою та підтримкою населення [16, с. 14]. Англійський досвід підготовки поліцейських відрізняється гуманістичною спрямованістю навчального процесу, тривалим терміном навчання констеблів за місцем роботи, найретельнішим відбором кандидатів на службу до кримінальної поліції, організацією їх навчання, акцентом на самостійне несення служби поліцейськими вже на початковому етапі проходження служби.

Для британської моделі характерна висока ступінь демократичності та гласності складання іспитів, а також подачі апеляції щодо їх результатів. Наприклад, у загальнобританському відомчому журналі «Police Review» («Поліцейський огляд») регулярно друкуються різноманітні варіанти екзаменаційних білетів і завдань для отримання посади інспектора (сержанта та інших посад). Претенденти не тільки мають можливість заздалегідь ознайомитися з їх змістом, але й надіслати свої відповіді поштою, які у певних випадках зараховуються і є підставою для підтвердження складання іспиту.

Х. Пітерс у ракурсі компетентнісного підходу в поліцейській освіті констатує, що перехід до співробітництва поліції з громадськістю в Північній Европі супроводжувався реформами в поліцейській освіті, які були спрямовані на поліпшення якості роботи поліції. У Нідерландах поліція використовує подвійну систему освіти та підготовки кадрів з метою сприяння чітким зв'язкам між теорією та практикою, враховуючи спільну 3 поліцейськими установами базу для підготовки співробітників поліції, формулюючи професійні вимоги різних поліцейських функцій, коли навчальні заклади визнача- 


\section{Адміністративне право}

ють навчальну програму і вимоги навчання, що відповідають професії [17, р. 90-114].

Слід звернути увагу, що дослідники за кордоном розрізняють поняття «навчання» та «освіта» стосовно професійної підготовки поліцейських. Наприклад, Д. Кокс вважає, що навчання поліцейських передбачає забезпечення громадського порядку, тоді як поліцейська освіта прагне спонукати офіцерів, які активно взаємодіють 3 різними верствами суспільства, до більш гнучкого мислення. Відсутність спеціальної програми освіти поліцейських для підтримки цього культурного переходу пояснює затримку між нововведеннями в охороні громадського порядку та їх застосуванням на практиці [18, p. 3-22].

Переважна більшість американських та європейських дослідників висловлює думку, що рівень інтелекту поліцейського має бути вищим ніж у пересічного громадянина. Представники цього підходу ставлять питання про необхідність щонайменше чотирирічної підготовки правоохоронців, аргументуючи це тим, що, в порівнянні 3 їх менш освіченими товаришами по службі, поліцейські $з$ вищою освітою є менш авторитарними та догматичними, більш обачливими, мають кращі комунікативні навички та характеризуються більш позитивним ставленням до проблем співпраці із населенням.

\section{Висновки}

Аналізуючи систему підготовки кадрів у зарубіжних державах, слід наголосити на тому, що поліцейські системи розвинутих держав світу мають довготривалу історію, значний досвід боротьби зі злочинністю й охорони громадського порядку, тісні взаємозв'язки між собою. У результаті цього у кожній державі сформувалась своя, унікальна, система підготовки кадрів для правоохоронних органів, яка розвивалась тривалий час під впливом як територіальних, історичних, політичних, економічних чинників, так і особливостей національних правових систем.

Аналіз сучасної європейської системи підготовки кадрів у правоохоронній сфері дає також підставу встановити характерну тенденцію, яка полягає в уніфікації національних законодавств, функціональних повноважень та завдань професійного навчання персоналу 3 одночасним збереженням спеціалізованих (суто поліцейських) інституцій підготовки кадрів. Сучасні виклики та загрози у правоохоронній сфері спонукають до розширення формату співпраці працівників правоохоронних органів, громадськості, незалежних експертів та науковців різних галузей наук з питань удосконалення методик підготовки кадрів для безпекового сектору держави.

Система професійної підготовки правоохоронців в Україні є одночасно органічною складовою частиною державної системи освіти і базою професійної підготовки поліцейських. Головне ії завдання - сприяння формуванню професійного ядра висококваліфікованих фахівців з усіх напрямів діяльності поліції, надання їм необхідних знань, навичок та вмінь працювати в умовах розбудови державності, формування ринкових відносин.

Зміцнення кадрового потенціалу у правоохоронній діяльності є одним з основних чинників забезпечення ефективної діяльності правоохоронних органів будь-якої країни.

\section{Лiтература \\ 1. Dmytro Shvets, Olena Yevdoki-} mova, Ivan Okhrimenko, Yana Ponomarenko, Yurii Aleksandrov, Svitlana Okhrimenko, Kostiantyn Prontenko. The New Police Training System: Psychological Aspects. Postmodern Openings, (Web of Science). 2020, Volume 11, Issue 1 Supl. 1, pages: 200-217. https:/doi. org/10.18662/po/11.1sup1/130

2. Feltes T. Community-oriented policing in Germany. Policing: An International Journal of Police Strategies and Management. 2002. Vol.25. №1. P. 48-59.

3. Peace R. Probationer training for neighborhood policing in England and Wales. Policing: An International Journal of Police Strategies and Management. 2006. Vol. 29. №2. P. 335-346.

4. Bayley D. H., Bittner E. Learning the skills of policing. Law and Contemporary Problems. 1984. Vol. 47, No. 4. P. 35-59. 
5. Roberg R., Bonn S. Higher education and policing: where are we now? Policing: An International Journal of Police Strategies and Management. 2004. Vol.27. №4. P. 469-486.

6. Sherman L. Professional policing and liberal democracy. The 2011 Benjamin Franklin Medal Lecture. URL: www.crim.cam. ac.uk/research/experiments/franklinfinal2011. pdf (дата звернення: 2.10.2020).

7. Заросило В. О. Порівняльний аналіз адміністративної діяльності міліції України та поліції зарубіжних країн (Великобританії, США, Канади та Франції) : автореф дис. ... канд. юрид. наук : 12.00.07. Київ : Національна академія внутрішніх справ, 2002. 20 с.

8. Петросова О. В. Европейська система освіти підготовки управлінських кадрів у правоохоронній сфері. Науковий вісник Академії мунічипального управління. Серія : Управління. 2012. Вип. 2. С. 271-278.

9. Швець Д. В. Використання закордонного досвіду в системі підготовки кадрів для органів і підрозділів Національної поліції України Сучасні проблеми правового, економічного та сочіального розвитку держави: тези доп. V Міжнар. наук.-практ. конф. (м. Харків, 18 листоп. 2016 р.) / МВС України, Харків. нац. ун-т внутр. справ. Харків, 2016. C. 238-241.

10. Organisation der Bayerischen Polizei. Polizei-Fehrungsakademie. URL: https:// www.polizei.bayern.de/wir/organisation/ organigramm/index.html/3250 (дата звернення 17.09.2020)

11. Федченко О. Структура поліцейських органів держав EC та правове регулювання їх діяльності // Актуальні проблеми управління та службово-оперативної діяльності органів внутрішніх справ у сучасний період розвитку державності України : матеріали Всеукр. наук.-практ. конф. (м. Київ, 26 жовт. 2007 р.). Київ : Леся, 2008. C. $72-77$.

12. Харчук Н. Р. Процедура підготовки поліцейських кадрів в ФРН // Освіта, мова та культура в процесі глобальних трансформацій : збірник тез круглому столу для науково-педагогічних та педагогічних працівників (м. Київ, 1 квітня 2016). К.: КІКВС, 2016. C. 49-53.
13. Мартиненко О. Система підготовки польської поліції (за матеріалами МВС України). URL: http://khpg.org/ index.php?id=1399022448 (дата звернення 12.09.2020).

14. Про поліцію: закон Республіки Польща // Право : портал. URL: http://pravo. org.ua/files/Criminal\%20justice/Poland.pdf (дата звернення: 23.06.2020).

15. Полиция зарубежных стран: система организации и опыт профессиональной подготовки кадров : учебное пособие / Якубов А. С., Асямов С. В., Таджиев А. А., Миразов Д. М. Ташкент : Академия МВД Республики Узбекистан, 2010. 449 с.

16. Заросило В. О. Порівняльний аналіз адміністративної діяльності міліції України та поліції зарубіжних країн (Великобританії, СІІА, Канади та Франції) : автореф дис. ... канд. юрид. наук : 12.00.07. Київ : Національна академія внутрішніх справ, 2002. $20 \mathrm{c}$.

17. Peeters H. Constructing comparative competency profiles: the Netherlands experience. International Perspectives on Police Education and Training. Routledge, 2013. P. 90 - 114.

18. Cox D. Educating police for uncertain times: the Australian experience and the case for a normative approach. Journal of Policing, Intelligence and Counter-Terrorism. 2011. Vol. 6. №1. P. 3-22.

19. Telep C. W. The impact of higher education on police officer attitudes toward abuse of authority. Journal of Criminal Justice Education. 2011. Vol. 22. № 3. P. 392-419.

\section{SHVETS Dmytro, YEVDOKIMOVA Olena POLICE EDUCATION: EUROPEAN APPROACHES TO THE ORGANIZATION AND DEVELOPMENT TRENDS}

The aim of the article was to analyze the results of the already implemented reforms of police training systems in foreign countries in the context of the possibility of further use of the already gained experience in the reorganization of police education and error prevention. The authors set themselves the goal to reveal the main features of the training of law enforcement officers in European countries in the perspective of historical, economic, social, organizational factors. 


\section{Адміністративне право}

у статті досліджено європейсъкі підходи до підготовки кадрів для полічї. Показано, що вони детермінуються низкою чинників, таких як: державна політика, ідеологія і соиіальні настановлення; начіонально-історичні традицй; освітні концепий, ідеї та принципи; специбіка національних правових систем; особливості організації та регулювання діяльносmi правоохоронних органів тощо. Зазначено, що тенденціями розвитку систем підготовки поліцейсъких у європейсъких країнах можна вважати посилення їх кооперациї, унібікацію національних законодавств, активну націленість на співпрацю із суспільством та збільшення у програмах підготовки частки соиіально-поведінкових наук.

Ключові слова: поліщейсъка освіта, суспільство, програми підготовки, законодавство, правоохоронні структури, правова система.

European approaches to police training have been explored in the context of both legal and sociopsychological aspects. It is shown that they are determined by a number of factors, such as: public policy, ideology and social attitudes; national-historical traditions; educational concepts, ideas and principles; specifics of national legal systems; features of organization and regulation of law enforcement agencies, etc. It is determined that the tendencies of development of police training systems in European countries can be considered the strengthening of their co- operation, unification of national legislation, active focus on cooperation with society and increase in the share of social and behavioral sciences in training programs.

The system of professional training of law enforcement officers in Ukraine is both an organic part of the state education system and a base for professional training of police officers. Its main task is to promote the formation of a professional core of highly qualified specialists in all areas of police activity, providing them with the necessary knowledge, skills and abilities to work in a state-building environment, the formation of market relations.

Strengthening human resources in law enforcement is one of the main factors in ensuring the effective operation of law enforcement agencies of any country.

The current police education in Ukraine is characterized by the approximation of national standards of training to the requirements established in the Member States of the European Union. But at the same time, it should be borne in mind that due to many historical and other reasons, the conditions of professional activity of police officers in Ukraine differ significantly from Western models. Therefore, by simply copying the police training system of any country, such as Britain, Germany or Poland without proper adaptation to the peculiarities of our society and state, we will get a non-viable structure that will not be able to train personnel for service in the realities of our state. 


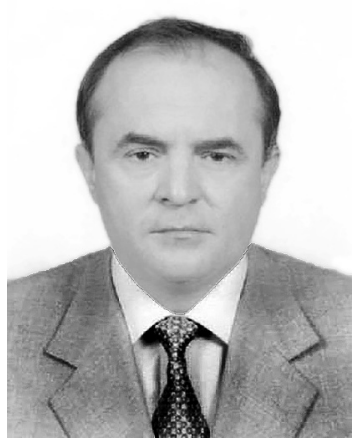

\section{АДМІНІСТРАТИВНО-ПРАВОВЕ ЗАБЕЗПЕЧЕННЯ КОРПОРАТИВНОГО УПРАВЛІННЯ}

\section{БАНДУРКА Олександр Олександрович - доктор юридичних наук, професор Міжнародної академії управління персоналом}

DOI 10.32782/LAW.2020.3.4

\begin{abstract}
В статье исследованъ европейские подходь к подготовке кадров для полиции. Показано, ито они детерминируются рядом бакторов, таких как: государственная политика, идеология и сочиальные установки; начионально-исторические традиции; образовательнъе кониепции, идеи и принципъ, специфика национальнъхх правовых систем; особенности организации и регулирования деятельности правоохранительных органов и тому подобное. Отмечено, ито тенденциями развития систем подготовки полицейских в европейских странах можно считать усиление их кооперации, унификации национальных законодательств, активная направленность на сотрудничество с обществомнаселением и увеличение в программах подготовки доли сочиально-поведенческих наук.

Ключевъе слова: полицейское образование, общество, программв подготовки, законодательство, правоохранительные структурь, правовая система
\end{abstract}

\section{Постановка проблеми}

Створення великих, середніх і малих корпоративних структур обумовило не тільки важливі переваги у порівнянні з роздробленими підприємствами малого та середнього бізнесу, а й поставило на порядок денний формування ефективної системи управління економікою України, зокрема, системи правового регулювання корпоративного управління, розробки рекомендацій щодо зацікавленості працівників - власників у ре- зультатах діяльності відкритих акціонерних товариств (корпорація).

Мета і завдання статті полягають у тому, щоб охарактеризувати поняття і визначення корпорації та розглянути основні положення адміністративно-правового забезпечення корпоративного управління.

Стан наукового дослідження проблеми корпоративного управління розкривається в працях вітчизняних науковців-юристів і економістів, зокрема О.П. Гетьманець, О.М. Бандурки, І.Л. Райніна, О.В. Носової, В.В. Холода, Т.В. Назарчука, М.М. Шкільняка та інших, але вказаними вченими не розглянуте питання адміністративно-правового забезпечення корпоративного управління.

\section{Виклад основного матеріалу}

Економіка України включена в процес створення глобальної економіки, в системі якої товари, послуги, фінансовий капітал, знання, інформація, ідеї, кадри вільно переміщуються 3 країни в країну перетинаючи економічні, політичні та адміністративні кордони та відстані.

У таких умовах особливого значення набуває правове забезпечення управління економічними процесами, управління в окремих галузях народного господарства, управління окремими підприємствами, фірмами, іншими суб'єктами господарювання. Процеси глобалізації економіки, як на міжнародному 


\section{Адміністративне право}

рівні, так і в національних масштабах, викликали необхідність інтеграції господарської діяльності як на рівні окремих суб'єктів господарювання, так і між суб'єктами господарювання різних країн. Зростаючий рівень міжнародної і внутрішньої конкуренції змушує суб'єктів господарювання шукати шляхи удосконалення власної діяльності, підвищувати конкурентоздатність, об'єднувати потенціал в боротьбі за виживання та ринкове співробітництво. Вказані процеси в управлінні економікою потребують, перш за все, належного адміністративно-правового забезпечення організації підприємницької діяльності, управління в корпоративних інтегрованих структурах, найбільш масовим серед яких є акціонерні товариства.

Відкриті акціонерні товариства (ВАТ) є по суті корпоративними об'єднаннями, під якими взагалі розуміють не тільки корпоративні товариства, які виступають як самостійні юридичні особи, але і групи юридичних або самостійних господарських підприємств, що ведуть спільну діяльність на основі консолідації активів або договірних (контрактних) відносин для досягнення загальних цілей. ${ }^{1}$

Термін «корпорація» застосовується як синонім терміну «акціонерне товариство», яке має свою організаційну структуру наділену певними функціями управління. Під корпорацією розуміють юридичне об'єднання 3 певними економічними цілями та власною системною управління, яке передбачає пайову (дольову) участь власників, правовий статус і правоздатність якого визначається місцем і метою його створення.

Адміністративно-правове забезпечення корпоративного управління реалізується через систему взаємодії між акціонерами i керівництвом компанії, фірми, корпорації, включаючи раду директорів, керівників відділів і служб, інших зацікавлених осіб. За допомогою корпоративного управління, в т.ч. адміністративно-організаційних заходів, реалізуються права акціонерів, формується кадровий персонал, створюються матеріальні та фінансові ресурси, здійснюється контр-

\footnotetext{
${ }^{1}$ Олексій Цурак Система корпоративного управління в Україні: стан та перспективи // Схід. - № 2 (80). - 2007. - C. 1-4.
}

оль як за діяльністю керівників корпорації, так і інших працівників корпорації, вирішуються інші питання виробничого характеру.

Основним предметом корпоративного управління $\varepsilon$ контроль за здійсненням фінансової і господарської діяльності корпорацій, без втручання в оперативне, технологічне і тактичне управління.

Корпоративне управління полягає у реалізації адміністративно-правових відносин між менеджерами корпорацій та їх власниками (акціонерами) 3 іншими зацікавленими сторонами, пов'язаними із забезпеченням ефективності господарської діяльності корпорації та задоволенням інтересів власників.

Адміністративно-правове забезпечення корпоративного управління вимагає від корпорації чіткого розподілу обов'язків між менеджерами, наявності специфічних органів управління, особливих зв'язків корпорації із оточуючим середовищем (органами влади, місцевого самоврядування, контролюючими органами), належним чином оформлених взаємовідносин із партнерами, постачальниками, кредиторами, споживачами, громадськістю.

Адміністративно-правове забезпечення корпоративного управління грунтується на положеннях Господарського і Цивільного кодексів України, Кодексу України про адміністративні правопорушення, Закону України «Про холдингові кампанії» ${ }^{2}$ (2006), Закону України «Про ратифікацію Конвенції про трансатлантичні корпорації» ${ }^{3}$ та інших законах, які регулюють в тій чи іншій мірі управлінську діяльність.

Основним управлінським документом корпорації є її статут, в якому має бути встановлена система внутрішнього управління, яке здійснюється Загальними зборами акціонерів, Наглядовою Радою, Ревізійною комісією, Радою директорів, керівниками галузевих служб і структурних підрозділів корпорації. Рада директорів (директор) ви-

\footnotetext{
${ }^{2}$ Про холдингові кампанії : закон України // Вiдомості Верховної Ради України, 2005. - № 34. C. 291.

${ }^{3}$ Про ратифікацію Конвенції про трансатлантичні корпорації : закон України // Відомості Верховної Ради України, 1999. - № 35. - С. 323.
} 
рішує адміністративно-правові питання (кадрові, фінансові, маркетингові, організаційно-функціональні тощо).

Наявність ефективної структури корпоративного управління є питанням надзвичайної важливості. Корпоративне управління містить у собі комплекс засбів управління діяльністю окремої корпорації з боку ради директорів і менеджменту, що торкається таких аспектів, як:

- постановка корпоративних цілей (включаючи визначення економічної вигоди для власників);

- управління поточною діяльністю корпорації;

- врахування інтересів учасників корпоративних відносин;

- забезпечення відповідності корпоративної діяльності і корпоративної культури вимогам діючого законодавства, нормативній базі і загальноприйнятим нормам ділового обороту;

- захист інтересів акціонерів і інвесторів.

Корпорація - організація, визнана юридичною особою, заснована на об'єднаних капіталах (добровільних внесках), що передбачає часткову власність, що здійснює яку-небудь соціально корисну діяльність, і характеризується значною концентрацією управлінських функцій на верхньому рівні ієрархічної структури. Дана форма організації підприємницької діяльності має широке поширення в економічно розвитих країнах і успішно розвивається в Україні.

Форми корпоративного управління використовуються не тільки в сфері економіки, а й в інших сферах суспільного життя, зокрема, в правоохоронних органах і правоохоронних організаціях.

В окремих органах центральної виконавчої влади створюються наглядові ради, спостережні комісії, громадські ради, колегії та інші структури колегіального управління та контролю.

Згідно ст. 51 Закону України «Про національну поліцію» прийом на службу в органах поліції здійснюється лише через поліцейські комісії, які є громадськими структурами. При Міністерстві внутрішніх справ діють громадські ради. Вони діють при всіх головних управліннях поліції в областях.
Спеціальні незалежні конкурсні комісії розглядають кандидатури на керівні посади Державного бюро розслідувань, спеціальної антикорупційної прокуратури, Національного антикорупційного бюро України. В системі Національного банку України, Укрзалізниці, Нафтогазу діють наглядові ради. Адвокатура, як правозахисна самоврядна організація має свої контрольні, ревізійні, кадрові органи, які діють за методом корпоративного управління.

Керівники різних відомств все частіше звертаються до вивчення громадської думки, проведення громадських експертиз, залучення представників громадськості до розгляду поточних питань управління, до встановлення партнерських відносин з громадянами.

У Законі України «Про національну поліцію» передбачено, що поліція взаємодіє на партнерських засадах з громадськими організаціями, звітує перед громадськістю.

Корпорація, як організація, являє собою штучно створену соціальну групу інституціонального характеру, що виконує визначену суспільну функцію (виробництво, нагромадження капіталу і рахунків, впорядкований розподіл коштів), орієнтовану на досягнення взаємозалежних і специфічних цілей у певній сфері людської діяльності. Виходячи 3 того, що корпорація являє собою колективне утворення, організацію, що має статус юридичної особи, створену об'єднанням капіталів (добровільних внесків), яка здійснює будь-яку соціально корисну діяльність, можна виокремити визначені ознаки, що характеризують такі корпоративні утворення:

- об'єднане утворення, що функціонує у відповідності з визначеними цілями;

- об'єднання капіталу;

- здійснення соціально-значущої діяльності в широких масштабах (виробництво, фінанси, створення матеріальних благ, торгівля, сировинні і переробні галузі);

- статус юридичної особи.

Основними задачами корпоративного управління 6 :

- створення і забезпечення діяльності ефективного механізму аналізу, що тече i стратегічного Управління, прийняття управлінських рішень і контролю за діяльністю товариства; 


\section{Адміністративне право}

y cmammi розкрито сутність адміністративно-правового забезпечення корпоративного управління, висвітлено роль $i$ місце керівних органів корпорацій, завдання $i$ ияілі корпоративного управління, показана специбіка управління корпоративними об'єднаннями. Корпоративне управління охарактеризоване як невід'ємний бактор розвитку економіки в сучасних умовах. Підкреслено, що головним завданням адміністративно-правового забезпечення корпоративного управління $\epsilon$ задоволення інтересів та прав акиіонерів та інших зачікавлених сторін в ефективній діяльності корпорачій. Необхідність корпоративного управління обумовлена тим, шо корпорачія, як власність, належить власникам чи інвесторам, а права управління делеговані раді директорів $і$ менеджменту, шо породжує інколи конблікт інтересів, який має бути розв'язаний в процесі управління.

Ключові слова: корпорачія, акиіонери, управління, рада директорів, економіка, бізнес.

- забезпечення однакового і справедливого відношення до всіх акціонерів (у тому числі до дрібних й іноземних) і можливості всім акціонерам використовувати ефективні способи захисту у випадку порушення їх прав;

- балансування інтересів акціонерів, менеджерів, працівників, клієнтів, партнерів і постачальників акціонерного товариства, тобто зацікавлених осіб, держави і громадськості. ${ }^{4}$

\section{Висновок}

Корпоративне управління слід сприймати як важливий фактор економічного розвитку та необхідну умову функціонування в міжнародному та національному конкурентному середовищі. Корпоративне управління є невід'ємною складовою ринкової економіки, умовою для розвитку приватного підприємства.

\footnotetext{
4 Сутність корпоративного управління https:// pidru4niki.com/1 $130110752406 /$ menedzhment/ sutnist_korporativnogo_upravlinnya
}

SUMMARY
The essence of corporate governance
administrative and legal support is revealed; the
role and place of corporation governing bodies,
objectives and goals of corporate governance are
highlighted; the specifics of the corporate association
governance is shown in the article. The corporate
governance is characterized as an integral factor
of the economy development in modern conditions.
It is emphasized that the main task of the corporate
governance administrative and legal support is to
satisfy shareholders' and other interested parties'
interests and rights in the corporations' efficient
activity. The necessity of corporate governance
is caused by the fact that the corporation, as
property, belongs to the owners or investors, and
the management rights are delegated to the board
of directors and management, sometimes it gives
rise to a conflict of interest that should be resolved
during the management process.
Keywords: corporation,
management, board of directors, economy, business.

Корпоративне управління розглядається як комплекс взаємодії між акціонерами і керівництвом корпорації в особі Ради директорів, інших керівних структур з зацікавленими сторонами, які мають відношення до корпорації.

\section{Лiтература}

1. Цурак Олексій Система корпоративного управління в Україні: стан та перспективи // Схід. - № 2 (80). - 2007. - С. 1-4.

2. Про холдингові кампанії : закон України // Відомості Верховної Ради України, 2005. - № 34. - С. 291.

3. Про ратифікацію Конвенції про трансатлантичні корпорації : закон України // Відомості Верховної Ради України, 1999. № 35. - C. 323.

Сутність корпоративного управління https:/pidru4niki.com/ 1130110752406/ menedzhment/sutnist_korporativnogo_ upravlinnya 


\title{
ПУБЛЧНІ ПОСЛУГИ У СФЕРІ ПЦПРИЕМНИЦЫКОӦ ДІЯЛЬНОСТІ ЯК АДМІНІСТАТИВНО-ПРАВОВА KATEГОРIЯ
}

\author{
ОБРУСНА Світлана Юріївна - доктор юридичних наук, доцент, професор \\ кафедри державно-правових дисциплін Черкаського національного університету \\ імені Богдана Хмельницького \\ https://orcid.org/0000-0001-9354-9235 \\ ГОЛОВАЧ О.А. - аспірант Харківського національного університету \\ внутрішніх справ
}

\section{Постановка проблеми}

У сучасних умовах реформаційних процесів, що відбуваються в Україні, утвердження оновленої адміністративно-правової доктрини, в основу якої покладено людиноорієнтовану ідеологію, за якою держава має служити інтересам громадян і діяти на їх благо через всебічне забезпечення пріоритету прав, свобод і законних інтересів у сфері публічної адміністрації, розширення сфери надання публічних послуг, актуалізується питання дослідження адміністративно-правового регулювання їх надання в межах окремих видів діяльності. Крім того, наявність розгалуженої мережі суб'єктів надання різних видів публічних послуг, численних, а інколи і суперечливих нормативно-правових актів, негативно впливають як на використання ресурсу публічних послуг у цілому, так і в окремих сфеpax, у тому числі у сфері підприємницької діяльності.

Варто зазначити, що під час формування вітчизняної теорії публічних послуг у сфері підприємницької діяльності залишається все ще недостатньо розробленим загальноприйнятий понятійно-категоріальний апарат, який надалі 6 використовувався у фаховій літературі, правотворчій та правозастосовній практиці. Вказана проблематика набуває особливої актуальності в умовах реалізації пріоритетних напрямів державної політики щодо реалізації Стратегії розвитку України «Україна-2020», децентралізації влади в Україні, євроінтегаційних процесів, імплементації європейських та міжнародних стандартів тощо.
Аналіз останніх досліджень і публікацій

Різні аспекти публічних послуг у межах юридичної науки досліджували В. Авер'янов, Ю. Битяк, В. Бевзенко, І. Коліушко, Т. Коломоєць, В. Колпаков, А. Комзюк, О. Копиленко, С. Кузніченко, О. Кузьменко, В. Куйбіда, Р. Мельник, О. Миколенко, Д. Приймаченко, М. Рабинович, В. Развадовський, О. Рябченко, А. Селіванов, С. Стеценко, В. Тимощук, Ю. Шаров та інші вчені.

На рівні дисертаційних робіт окремі питання певних видів публічних послуг вивчали I. Ковбас, А. Приймак, Ю. Шиндель; аспекти адміністративно-правового регулювання підприємницької діяльності досліджували О. Клим, Н. Саніахметова, О. Баклан, ‥ Грицаєнко. Однак в умовах утвердження людиноцентриської ідеології адміністративного права, суттєвого оновлення нормативно-правової бази комплексне наукове дослідження публічних послуг у сфері підприємницької діяльності має вагоме наукове та практичне значення. Системний підхід до дослідження публічних послуг у сфері підприємницької діяльності передбачає також формування належного понятійно-категоріального апарату, у тому числі й визначення змісту поняття «публічні послуги у сфері підприємницької діяльності».

Мета статті полягає у визначенні змісту поняття «публічні послуги у сфері підприємницької діяльності», характеристиці його правової природи та визначенні ознак як адміністративно-правової категорії. 


\section{Адміністративне право}

\section{Виклад основного матеріалу}

Одним із визначальних чинників забезпечення реалізації прав особи в Україні, підвищення рівня довіри громадян до інститутів держави є вдосконалення механізмів взаємодії між особою і державою, зокрема й у напрямку надання публічних послуг як у цілому, так і у сфері підприємницької діяльності. Нині надзвичайно актуально не лише провести переорієнтацію в публічному управлінні, а й змінити роль публічних інститутів у взаємовідносинах 3 особою, установивши як пріоритет якісне надання їй послуг.

Для реалізації вказаного завдання варто удосконалити сучасні та створити нові інституційні та правові засади підвищення якості публічних послуг. Його розв'язання ускладнюється й тим, що нині як на теоретичному, так і законодавчому рівнях немає єдиного підходу до розуміння публічних послуг і визначення їх сутності, що стосується й сфери підприємницької діяльності. Наука адміністративного права та чинне законодавство оперують такими категоріями, як «публічні послуги», «державні послуги», «муніципальні послуги», «адміністративні послуги» тощо. Ці поняття розуміють і як синоніми і розмежовують, визначаючи їх особливі риси. Хибно було 6 як змішувати ці поняття, так і протиставляти їх, оскільки одна і та ж послуга може бути і публічною, і державною.

Для формулювання поняття «публічні послуги у сфері підприємницької діяльності» варто проаналізувати кожну його складову. Звернемось до етимології слова «публічний». Загальновідомо, що поняття «публічний» походить від латинського publicus - суспільний, народний та за «Словником іншомовних слів» означає той, який відбувається у присутності публіки, людей; прилюдний, привселюдний, гласний, відкритий; призначений для широкого відвідування, користування; громадський, загальний, загальнодоступний [1].

В «Академічному тлумачному словнику української мови» подано також кілька значень вказаного слова: 1) який відбувається в присутності публіки, людей; прилюдний, привселюдний, гласний, відкритий;. 2) призначений для широкого відвідування, користування; громадський, загальний, загальнодоступний. 3) стосується публіки [2].
В. Даль, виводячи зміст терміну «публічний» із слова «публіка», визначає його як всенародний, оголошений, явний, відомий; організований для публіки, суспільства, народний, загальнонародний, всенародний, вселюдний; всіма спільний, такий, що всім належить [3, с. 535]. О. Кілієвич перекладає англійське слово public українською мовою як громадський, публічний, державний $[4,-$ c. 292].

У юридичних енциклопедіях та словниках термін «публічний» найчастіше вживається в таких словосполученнях як «публічна влада» (суспільно-політична влада, народовладдя) та «публічне право» (система правових норм, якими регулюються суспільні відносини у сфері публічної влади) [5, с. 196-198].

Аогічно, що органи публічної влади створюються $з$ метою реалізації покладених на них функцій, виходячи із цього, невід'ємним $\epsilon$ зобов'язання щодо надання послуг у сфері, до якої вони належать. I якщо функції органи влади реалізують із метою задоволення суспільних потреб, то послуги, які ними надаються, з метою реалізації призначення служити потребам та інтересам своїх громадян, тобто конкретної потреби особи. Причому акцент робиться на тому, що завдяки задоволенню таких потреб держава реалізує свою сутність як правова й демократична.

Поняття «послуга» в контексті «служіння» суспільству належить до кола соціально-економічних та правових категорій. Узагальнення досліджень учених-економістів дає можливість визначити низку підходів до розуміння поняття «послуга» це: 1) діяльність; 2) економічне благо; 3) різновид товару. На основі аналізу вказаних підходів С. Плакида визначає таке поняття послуги з погляду економічної науки: специфічний товар інфраструктурного характеру, який виражається в діяльності, пов'язаній із забезпеченням нормального або більш ефективного функціонування учасників ринку [6, с. 242].

У юриспруденції поняття «послуга» більш грунтовно досліджене в цивільно-правовій та господарсько-правовій науці. Хоча, як свідчить аналіз публікацій, у цивілістичній та господарсько-правовій доктрині до сьогодні відсутне легальне і єдине доктринальне визначення поняття «послуга». В. Рєзнікова, 
проаналізувавши сучісні концепції, узагальнила їх до наступних: 1) сутність послуги визначається через дію (Ю. Калмиков, С. Емельянчик, Д. Степанов та ін.); 2) послуга як результат діяльності ( Е. Романова, С. Алексєєв, Н. Індюков, М. Кротова, О. Красавчиков та ін.); 3) сутність послуги виводиться через сукупність (нерозривну єдність) діяльності та її результату (Т. Л. Левшина, Ю. В. Романець та ін); 4) послуга як діяльність, що не має уречевленого результату (О. Іоффе, С. Шешенін та ін.); 5) відмежування послуги від виду робіт за ознакою відсутності уречевленого результату; 6) послуга як різновид блага через аналіз сутності блага; 6) послуги пов'язані безпосередньо або опосередковано із задоволенням особистісних потреб, але безпосередньо не спрямовані на виробництво будь-яких предметів [7].

3 погляду адміністративно-правової науки із запропонованих концепцій слушними будуть підходи, що визначають послугу як дію, діяльність. Крім того, розуміння послуги в цьому сенсі розглядається у поєднанні із словами публічні, державні, управлінські, муніципальні тощо.

У юридичній науці сформувалася низка підходів до визначення поняття «публічна послуга» та відокремлення його від суміжних понять. Так, О. Григораш виділяе такі підходи до його формулювання: 1) управлінська діяльність органів публічної влади та їх службових осіб, пов'язана із роботою з громадянами, підприємствами, установами, організаціями; 2) дії публічних суб'єктів із організації обслуговування населення, підприємств, установ, організацій та надання їм життєвонеобхідних благ; 3) публічні послуги, що надаються населенню у режимі цивільно-правового регулювання, але мають масовий характер, відповідальність за організацію яких несе орган публічної влади [8, с. 74].

А. Шаститко розглядає публічні послуги через їх основне завдання - підвищення ефективності державного управління - та пропонує два підходи до його розуміння: емпіричний (послуги, надані (у зв'язку з виконанням владних функцій) органами виконавчої влади і їхніми установами при безпосередній взаємодії з громадянами ) й теоретичний (послуги, що мають властивості приватних благ, але безпосередньо сполучені зі специфікацією й захистом прав власності окремих осіб) [9, с .33-34].

Ю. Тихомиров під публічною послугою розуміє здійснення дій уповноваженим суб'єктом для задоволення потреб і прав інших осіб [ 10, с.10].

Декілька підходів до поняття «публічні послуги» пропонує і $\mathcal{\Lambda}$. Міцкевич: 1) діяльність державного апарату, що служить платникам податків; 2) послуги, що характеризують лише сферу діяльності держави, в якій організовується життєзабезпечення населення (містобудування, транспортне сполучення, каналізація, водопостачання, освіта, охорона здоров'я тощо); 3) послуги, що уособлюють позитивне державне управління; 4) функції державних органів, які здійснюють відповідні суб'єкти: органи виконавчої влади, органи, місцевого самоврядування, державні та муніципальні установи; 5) спосіб обслуговування громадян (безпосередня взаємодія з громадянами при їх зверненні та прийомі) [11, с. 32].

Учені-адміністративісти (I. Коліушко,В. Тимощук, Б. Савченко, В. Сорока, О. Григораш) вважають, що публічними є всі послуги, що надаються публічним сектором, за рахунок публічних коштів та за надання яких відповідальність несе публічна влада. Вони мають виступати загальним поняттям та розрізнятися за ознакою суб'єктності на: державні, муніципальні, управлінські, соціальні, адміністративні [12, с. 117].

На основі аналізу праць вказаних та інших вчених В. Аегеза, розробляючи концепцію адміністративних послуг, пропонує таке їх визначення: врегульована публічно-правовими нормами діяльність органів публічної адміністрації щодо задоволення публічного інтересу з розгляду заяви фізичної або юридичної особи про видачу адміністративного акту (рішення, дозвіл, ліцензія, сертифікат, акт, посвідчення тощо), спрямована на забезпечення іiі прав і законних інтересів та/або на виконання особою визначених законом обов'язків шляхом фінансування за рахунок публічних коштів [13, с. 10].

Незважаючи на різні підходи, спільним у визначеннях, запропонованих науковцями, $\epsilon$ те, що це певна діяльність надавачів, спрямована на задоволення потреб та законних ін- 


\section{Адміністративне право}

тересів певних споживачів; послуги надаються суб'єктами публічного сектору і за їх надання відповідальність несе публічна влада.

Тобто ми можемо виділити певні ознаки публічних послуг: заявницький характер, публічно-правовий регламент, система суб'єктів їх надання - суб'єкти публічного адміністрування, орієнтованість на задоволення публічного інтересу. Такі ознаки визначає більшість дослідників. Деякі автори доповнюють ці загальні підходи та уточнюють чи виділяють окремі ознаки: 1) вони забезпечують діяльність загальнозначущої спрямованості;2) мають необмежене коло суб'єктів, що користуються ними; 3) здійснюються або органом державної й муніципальної влади, або іншим суб'єктом; 4) грунтуються як на публічній, так і на приватній власності [12, с.9-10]. Крім того, В. Аегеза досить слушно виділяє загальні (притаманні не лише публічним послугам, але й іншим послугам, які надаються суб'єктами публічної адміністрації) та спеціальні (публічний інтерес, індивідуальність, соціальна спрямованість, добровільність звернення, загальнодоступний характер, перевага соціального результату над економічним, безпосередня взаємодія із суб'єктами публічної адміністрації, доступність, прозорість тощо) ознаки публічних послуг [13, с. 10]. Названі ознаки характеризують публічну послугу як адміністративно-правову категорію.

Вважаємо, що базовим та таким, що потребує законодавчого закріплення, є визначення публічних послуг, запропоноване вченими-адміністративістами: послуги, що надаються публічним сектором, за рахунок публічних коштів та за надання яких відповідальність несе публічна влада. Вони мають розрізнятися за ознакою суб'єктності на державні, муніципальні, управлінські, соціальні, адміністративні тощо.

Для однозначного розуміння поняття «публічні послуги» доцільно закріпити його на законодавчому рівні, прийнявши відповідний закон, що регулював би досить широку сферу публічних послуг, оскільки вона значно ширша, ніж адміністративних, які є їх складовою.

Поняття підприємницької діяльності використовується у вітчизняному законодавстві як базова категорія в різних галузях права, у тому числі й адміністративного. Поряд із вка- заною категорією розглядається категорія «підприємництво».

Підходи до тлумачення вказаних понять знаходимо в працях учених різних галузей наук. Німецьким вченим Петером Верханом зазначено, що важко знайти таку складну i неоднозначну сферу діяльності, як підприємництво. У ринковому господарстві вона реалізується на перехресті економіки, політики, техніки, юриспруденції, психології й етики $[14$, с. 5].

Юридичний аспект цих категорій має базуватися на аналогічних економічних категоріях. У сучасній західній економічній літературі підприємництво визначається як тип поведінки, як динамічний процес, що має інноваційний характер, і тощо. У юридичній літературі використовуються поняття «підприємництво», «підприємницька діяльність». Заслуговуе на увагу декілька визначень.

В. Попандопуло визначає підприємницьку діяльність як сукупність правомірних вольових дій, що здійснюються професійно, систематично і на власний ризик особою, зареєстрованою як підприємець, з метою одержання прибутку [15, с. 20].

В. Сизоненко зазначає, що підприємництво - це не заборонена законом ініціативна, систематична діяльність приватних осіб (підприємців) і юридичних осіб, заснована на приватній або на іншій формі власності, спрямована на одержання прибутку від виробництва товарів, виконання робіт і надання послуг, здійснювана на власний ризик і під власну відповідальність[16, с. 5].

На думку Т. Кашаніної, підприємництво - ініціативна діяльність господарюючих суб'єктів, заснована на їх самостійності, особистій зацікавленості та відповідальності, новаторстві та ризику [17, с. 9]

Узагальнення поглядів учених дає можливість визначити іï як сукупність правомірних дій, які здійснюються професійно, систематично і на власний ризик особою, зареєстрованою як підприємець, з метою одержання прибутку.

Нормативне визначення підприємництва сформульовано у Господарському кодексі: самостійна, ініціативна, систематична, на власний ризик господарська діяльність, 
що здійснюється суб’єктами господарювання (підприємцями) 3 метою досягнення економічних і соціальних результатів та одержання прибутку [18].

\section{Висновки}

Підсумовуючи вище викладене, можемо зробити висновок про те, що поняття публічні послуги у сфері підприємницької діяльності з їх ознаками та підходами до розуміння - досить складна та багатогранна категорія адміністративного права. Дослідження проблематики публічних послуг у сфері підприємницької діяльності має бути спрямоване на вироблення єдиного теоретичного поняття, яке 6 вдало підтверджувалось практичною діяльністю органів публічної влади з реалізації владних повноважень, здійснюваних ними за вимогою підвладного суб'єкта. Саме тому, враховуючи наукові та законодавчі підходи до формулювання вказаного поняття, можна стверджувати, що публічні послуги у сфері підприємницької діяльності - це діяльність органів публічної влади та інших суб’єктів різних рівнів, що здійснюється за рахунок публічних і приватних коштів 3 надання фiзичним і юридичним особам певних благ, які є соціально значущими для суспільства і держави.

\section{Лiтература}

1. Словник іншомовних слів. URL: https://www.jnsm.com.ua/sis/index.shtml

2. Новий тлумачний словник української мови URL: http://sum.in.ua/s/publichnyj

3. В. Даль В. Толковый словарь живого великорусского языка: в 4 т. М.: Рус. яз., 1999. Т. 3: П. 1999. 576 с.

4. О. Кілієвич Англо-український глосарій термінів і понять з аналізу державної політики та економіки. К.: Вид-во Соломії Павличко «Основи», 2003. 510 с.

5. Юридична енциклопедія : в 6 т. / редкол. : Ю. С. Шемшученко (відп. ред.) та ін. К.: «Укр. енцикл.», 2003. Т.5 : П-С. 398 с.

6. Плакида С. Сутність поняття послуга: теоретичні аспекти. Інноваційна економіка. 2013. № 6 (44). C. 241-243

7. Рєзнікова В. Сутність категорії «послуга»: аналіз існуючих концепцій. URL: http:// radnuk.info/statti/230-tsuv-pravo/14859---lr---. $\underline{\mathrm{html}}$

8. Григораш О. Публічні послуги у сфері державного управління: поняття та зміст. Науковий вісник Чернівецького університету: Правознавство. 2007. № 385. С. 73-78

9. Шаститко А. Е. Организационные рамки предоставления публичных услуг. Вопросы экономики. 2004. №7. С. 150-155

10. Тихомиров Ю. А. Публичные услуги: спрос общества и реализующие его институты /Материалы 6 Международной конференции. Модернизация экономики и выращивание институтов. М: ВШЭ, 2005.

11. Публичные услуги: правовое регулирование (российский и зарубежный опыт): сборник / под общ. ред. Е. В. Гриценко,Н. А. Шевелевой. - М. :Волтерс Клувер, 2007. C. 32

12. Адміністративна процедура та адміністративні послуги. Зарубіжний досвід і пропозиції для України / І. Б. Коліушко (відп. ред.), В. П. Тимощук (авт. упоряд.). К. 2003. $496 \mathrm{c.}$

13. Аегеза Є.О. Концепція публічних послуг: адміністративно-правовий аспект: автореф. дис.... доктора юрид. наук: 12.00.07. Запоріжжя, 2017. 34 с.

14. Верхан Петер X. Підприємець: його економічна функція та суспільно-політична відповідальність. К. : Б.м., 1994. 59 с.

15. Попандопуло В. Коммерческое (предпринимательское право): учебник для студ. вузов, обучающихся по специальности «Юриспруденция». Серия Institutiones. М. : Юристь, 2003. 688 с.

16. Сизоненко В. Сучасне підприємництво: Навч.посіб. К.: Знання-Прес, 2008. $440 \mathrm{c}$

17. Кашанина Т. Предпринимательство: правовые основы. Предпринимательство. М.: Юрид. лит., 1994. 175 с

18. Господарський кодекс України: Закон України. Кодекс від 16.01.2003 № 436 IV. (зі змінами) URL: https://zakon.rada.gov.ua/ go/436-15

\section{REFERENCES}

1. Slovnyk inshomovnykh sliv [Dictionary of foreign words]. URL: https://www.jnsm.com. ua/sis/index.shtml 
2. Novyi tlumachnyi slovnyk ukrainskoi movy [New Ukrainian definition dictionary]. URL: http://sum.in.ua/s/publichnyj

3. Dal', V. (1999). Tolkovyj slovar' zhivogo velikorusskogo yazyka: $\mathrm{v} 4 \mathrm{t}$. [Definition dictionary of colloquial Great Russian]. (Vols. 1-4). (V. 3.) Moscow: Rus. iaz. 398. (in Russ.)

4. Kiliievych, O. (2003). Anhlo-ukrainskyi hlosarii terminiv i poniat $\mathrm{z}$ analizu derzhavnoi polityky ta ekonomiky [English-Ukrainian glossary of terms and concepts for the analysis of public policy and economics]. Kyiv: Osnovy. 510. (in Ukr.).

5. Shemshuchenko, Yu. S. (Eds.). (2003). Iurydychna entsyklopediia: v 6 t. [Legal encyclopedia]. (Vols. 1-6). (Vols. 5). Kyiv: Ukr. encycl. 398. (in Ukr.).

6. Plakyda, S. (2013). Sutnist poniattia posluha: teoretychni aspekty [The essence of the concept of service: theoretical aspects]. Innovatsiina ekonomika, 6 (44). 241-243 (in Ukr.).

7. Rieznikova, V. Sutnist katehorii «posluha»: analiz isnuiuchykh kontseptsii [The essence of the category «service»: analysis of existing concepts]. URL: http://radnuk.info/statti/230-tsuvpravo/14859---lr---.html

8. Hryhorash, O. (2007). Publichni posluhy u sferi derzhavnoho upravlinnia: poniattia ta zmist [Public services in the field of public administration: concept and content]. Naukovyi visnyk Chernivetskoho universytetu: Pravoznavstvo, 385. 73-78 (in Ukr.)

9. Shastytko, A. E. (2004). Organizacionnye ramki predostavleniya publichnyh uslug [Organizational framework for the provision of public services]. Voprosy ekonomiki, 7. 150-155 (in Ukr.)

10. Tikhomirov, Ju. A. (2005). Publichnye uslugi: spros obshchestva i realizuyushchie ego instituty [Public services: the demand of society and the institutions that implement it]. Modernizatsia ekonomiki $i$ vyrashchivaniie institutov. Moscow: VShE. (in Russ.)

11. Gritsenko, Ye. V., \& Shevelieva, N. A. (Eds.). (2007). Publichnye uslugi: pravovoe regulirovanie (rossijskij i zarubezhnyj opyt) [Public services: legal regulation (Russian and foreign experience)]. Moscow: Volters Cloover. P. 11 (in Russ.)

12. Koliushko, I. B., \& Tymoshchuk, V. P. (Eds.). (2003). Administratyvna protsedura ta administratyvni posluhy. Zarubizhnyi dosvid i propozytsii dlia Ukrainy [Administrative procedure

В Украӥні в умовах сучасних реформаційних прочесів актуальним $\varepsilon$ питання дослідження адміністративно-правового регулювання надання публічних послуг у межах окремих видів діяльності, у тому иислі у сфері підприємництва. Залишається все ще недостатньо розробленим понятійно-категоріальний апарат, який надалі б використовувався у фаховій літературі, правотвориій та правозастосовній практииі. Метою дослідження є визначення змісту поняття «публічні послуги у сфері підприємницької діяльносmі», характеристика його правової природи та визначення ознак як адміністративно-правової категоріі. Методами, що використовувались у даному дослідженні, $є$ : аналіз, синтез, порівняльноправовий, формально-юридичний, логіко-семантичний. Результати. Виконано аналіз поглядів науковиів щодо розуміння сутності публічних послуг та зроблено висновок про те, що спільним у визначеннях є: ие певна діяльність надавачів, спрямована на задоволення потреб та законних інтересів певних споживачів; послуги надаються суб'єктами публічного сектору $i$ за їх надання відповідальність несе публічна влада. Доведено, що базовим та таким, що потребує законодавчого закріплення $є$ визначення публічних послуг, запропоноване вченими-адміністративістами: послуги, що надаються публічним сектором, за рахунок публічних коштів та за надання яких відповідальність несе публічна влада. Вони мають розрізнятися за ознакою суб'єктності. Обгрунтовано необхідність закріплення поняття «публічні послуги» на законодавчому рівні. Визначено ознаки публічних послуг: заявницький характер, публічно-правовий регламент, система суб’єктів їх надання - суб'єкти публічного адміністрування, орієнтованість на задоволення публічного інтересу. Сбормульовано поняття підприємницької діяльності як сукупності правомірних дій, які здійснюються пробесійно, систематично $i$ на власний ризик особою, зареєстрованою як підприємець, з метою одержання прибутку. Висновок. Публічні послуги у сфері підприємнищької діяльності - досить складна та багатогранна категорія адміністративного права. Це діяльність органів публічної влади та інших суб'єктів різних рівнів, що здійснюється за рахунок публічних $i$ приватних коштів з надання ббізичним $i$ юридичним особам певних благ, які є сочіально значущими для суспільства і держави.

Ключові слова: послуги, публічні послуги, ознаки публічних послуг, підприємницька діяльність, публічні послуги у сбері підприємницької діяльності. 
and administrative services. Foreign experience and proposals for Ukraine]. Kyiv. 496 (in Ukr.).

13. Legeza, Ye. O. (2017). Kontseptsiia publichnykh posluh: administratyono-pravoryi aspect. [The concept of public services: administrative and legal aspect]. Extended abstract of doctor's thesis (12.00.07). Zaporizhzhia. 34 (in Ukr.).

14. Verhan, P. (1994). Pidpryiemets: yoho ekonomichna funktsiia ta suspilno-politychna vidpovidalnist [Entrepreneur: his economic function and socio-political responsibility]. Kyiv. 59 (in Ukr.).

15. Popandopulo, V. (2003). Kommercheskoe (predprinimatel'skoe pravo) [Commercial (business law)]. Moscow: Yurist. 688 (in Russ.)

16. Syzonenko, V. (2008). Suchasne pidpryiemnytstvo [Modern entrepreneurship]. Kyiv: Znannia-Pres. 440 (in Ukr.).

17. Kashanina, T. (1994). Predprinimatel'stvo: pravovye osnovy [Entrepreneurship: Legal Basis.]. Moscow: Jurid. lit. 175 (in Russ.)

18. Hospodarskyi kodeks Ukrainy: Zakon Ukrainy [Economic Code of Ukraine: Law of Ukraine]. Zakon Ukrayiny (16.01.2003 No 436 IV. with amendments). URL: https://zakon.rada. gov.ua/go/436-15

\section{S.Yu. Obrusna, O.A. Holovach PUBLIC SERVICES IN ENTREPRENEURSHIP ACTIVITIES AS ADMINISTRATIVE LEGAL CATEGORY}

In Ukraine, in the context of modern reform processes, the issue of studying of the administrative and legal regulation of the provision of public services within certain types of activities, including the field of entrepreneurship, is rather relevant. The conceptual and categorical apparatus, which could be further used in the professional literature, law-making and law enforcement practices, remains insufficiently developed. The aim of the research is to determine the content of the concept of "public services in the field of entrepreneurship activity", characterize its legal nature and define features as an administrativelegal category. The methods used in this study are analysis, synthesis, comparative legal, formal legal, logical and semantic methods. Results. The analysis of the standpoints of the scientists in the understanding of the essence of the public services was carried out and the conclusion was made that despite the different approaches, the common definitions offered by the researchers are that this is a certain activity of suppliers aimed at meeting the needs and legitimate interests of certain consumers; services are provided by public sector entities and these are the public authorities that are responsible for their provision. It was proved that the basic and needing legislative consolidation is the definition of public services, offered by scientists researching administrative sphere, which is as follows: public services are the services provided by the public sector at the expense of public funds and for the provision of which the public authorities are responsible. They have to differ in terms of subjectivity. For an unambiguous understanding of the concept of "public services", it is advisable to consolidate it at the legislative level by adopting an appropriate law that would regulate a fairly wide range of public services. The features of public services were determined: declarative nature, public law regulations, the system of subjects of their provision - subjects of public administration, focus on meeting public interests. The concept of entrepreneurial activity is formulated as a set of lawful actions that are carried out professionally, systematically and at their own risk by a person registered as an entrepreneur in order to make a profit. Conclusion. Public services in the field of entrepreneurial activity, with their features and approaches to understanding, is a rather complex and multifaceted category of administrative law. The public services in the entrepreneurship activity is defined as the activity of public authorities and other subjects of different levels, carried out at the expense of public and private funds to provide individuals and legal entities with certain benefits that are socially significant for the society and the state.

Keywords: services, public services, public services features, entrepreneurship activity, public services in the entrepreneurship activity. 


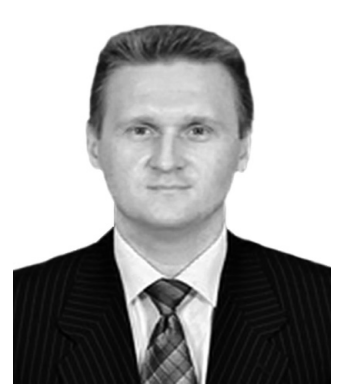

\section{ПЕРСПЕКТИВИ ЗАЛУЧЕННЯ ГРОМАДЯН ДО ОХОРОНИ ГРОМАДСЬКОГО ПОРЯДКУ В УКРАї̈Н}

ЗАВАЛЬНИЙ Михайло Володимирович - доктор юридичних наук, старший науковий співробітник, доцент кафедри адміністративного права і процесу факультету №1 Харківського національного університету внутрішніх справ; директор Науково-дослідного інституту публічної політики і соціальних наук https://orcid.org/0000-0003-4191-061X DOI 10.32782/LAW.2020.3.6

\section{Постановка проблеми}

Правоохоронна діяльність е силу своєї багатоаспектності й особливостей виконуваних функцій та завдань припускає активні дії не лише спеціалізованих органів і служб, але й багатьох інших установ і організацій, що здійснюють різні державні й недержавні повноваження. Складно знайти державний орган або громадську організацію, які не зацікавлені в ефективній правоохоронній діяльності, що й не реалізують ії хоча 6 у деякій частині. Правоохоронна діяльність зачіпає законні інтереси кожної людини, має високу суспільну значимість і дуже впливає на формування правової держави. Незважаючи на активну роль цих органів, підрозділи Національної поліції України, інші державні суб’єкти правоохорони здійснюють активну співпрацю щодо забезпечення правопорядку в країні як з окремими громадянами, так і їхніми об'єднаннями. Вітчизняне законодавство прямо передбачає можливість участі громадян в охороні громадського порядку й забезпеченні безпеки в країні. Насамперед, мова йде про громадські формування з охорони громадського порядку та державного кордону. Громадяни України відповідно до Конституції України мають право створювати громадські об'єднання для участі в охороні громадського порядку і державного кордону, сприяння органам місцевого самоврядування, правоохоронним органам, Державній прикордонній службі України та органам виконавчої влади, а також посадовим особам у запобіганні та припиненні ад- міністративних правопорушень і злочинів, захисті життя та здоров'я громадян, інтересів суспільства і держави від протиправних посягань, а також у рятуванні людей i майна під час стихійного лиха та інших надзвичайних обставин [1].

\section{Стан дослідження}

Проблеми правового регулювання участі громадян в охороні громадського порядку неодноразово ставали предметом дослідження цілої плеяди вітчизняних адміністративістів: В. Б. Авер'янова, М. І. Ануфрієва, Ю. П. Битяка, І. П. Голосніченка, Є. В. Додіна, А. Т. Комзюка, О. В. Кузьменко, О. М. Музичука, В. І. Олефіра, О. І. Остапенка, С. С. Юрка тощо.

Метою статті $є$ визначення перспектив існування та діяльності громадських формувань, діяльність яких спрямована на охорону громадського порядку та безпеки.

Виклад основного матеріалу

Необхідність залучення громадян до охорони громадського порядку та їхньої взаємодії з підрозділами Національної поліції України та іншими органами 3 правоохоронними функціями. Метою такої співпраці є протидія злочинним проявам та адміністративним правопорушенням. Однак, незважаючи на активне декларування необхідності широкого залучення громадян до охорони правопорядку, відсутня система діяльність як правотворців, так і органів вико- 
навчої влади в цьому напрямку. Незначний масштаб залучення громадськості до забезпечення правопорядку є побічним наслідком руйнування старої радянської системи, яка мала значний досвід 3 цього питання. Добровільні народні дружини та інші аналогічні структури мали масове поширення в країні. Наприкінці існування добровільні народні дружини налічували майже чотири мільйони залучених осіб. Підприємства та організації забезпечували існування значної кількості таких структур. За даними на 1990 рік в Українській РСР налічувалося понад 30 тисяч ДНД. За даними Департаменту персоналу, організації освітньої та наукової діяльності МВС України штатна чисельність Національної поліції України складає 149 тис. працівників. Таким чином, добровільні народні дружини мали дійсно широке поширення в нашій країні. Проблема зниження кількості осіб, які залучаються до охорони правопорядку, потребує додаткового дослідження. Насамперед, необхідно чітко визначити причини такого різкого зменшення активності населення, розробити концепцію підвищення їхньої ролі в охороні громадського порядку та взаємодії з правоохоронними органами.

Е засобах масової інформації поширеними $є$ публікації про те, що останніми роками значно підвищується активність громадян у забезпеченні безпеки в країні та усуненні внутрішніх та зовнішніх загроз. На превеликий жаль, мусимо констатувати, що в цьому випадку здійснюється певна підміна понять. Звісно, протягом 2014-2018 років було створено досить багато добровільних формувань правоохоронної спрямованості. Однак їхнє створення й подальша діяльність відбувалась із значними порушеннями вимог законодавства. Так звані активісти нерідко привласнювали суто державні повноваження щодо застосування сили до пересічних громадян. Діяльність таких структур нерідко пов'язується з порушеннями прав і свобод громадян. Такий стан справ є неприпустимим в дійсно правовій країні. Проблема 3 тими непередбаченими законом добровільними громадськими формуваннями правоохоронної спрямованості потребує негайного вирішення. Недопустимим є прихову- вання таких структур, як суто громадських об'єднань без належного нагляду та контролю з боку Національної поліції України. Особливо небезпечним є використання деякими державними структурами таких активістів для вирішення протизаконних питань у тих випадках, коли необхідно приховати свій зиск у їхньому вирішенні.

У наукових публікаціях виділяють дві групи громадських формувань, які беруть участь у правоохоронній діяльності: спеціально створені для протидії правопорушенням та охороні громадського порядку, також ті, для яких виконання правоохоронних функцій є додатковими до основної їхньої діяльності. До першої групи відносять громадські формування 3 охорони громадського порядку, громадські пункти охорони громадського порядку, товариські суди тощо. Основними критеріями ефективності діяльності цих суб'єктів є належний рівень забезпечення громадського порядку на території їхньої діяльності. До іншої групи суб'єктів відносять громадські, селищні, сільські, вуличні, квартальні, дільничні, домові комітети; ради ветеранів; батьківські комітети тощо. Для цих суб'єктів діяльність щодо охорони громадського порядку $\varepsilon$ неосновною. Виконання правоохоронних функцій ними є додатковою до їхньої основної діяльності. Адже основною метою їнього створення є господарська чи соціально-культура діяльність [2]. Незважаючи на їхній вплив на підтримання правопорядку на підприємствах, установах чи певній території, ми не можемо віднести їх до повноцінних суб'єктів правоохорони. На нашу думку, до суб'єктів правохорони доцільно відносити лише ті громадські формування, основною метою яких є правоохоронна діяльність.

Діяльність громадських формувань правоохоронної спрямованості врегульована низкою нормативно правових актів, серед яких особливо слід відмітити Закони України «Про громадські об'єднання» [3], «Про участь громадян в охороні громадського порядку та державного кордону» [1], «Про органи самоорганізації населення» [4], Кодекс України про адміністративні правопорушення [5]; Постанову Кабінету Міністрів 


\section{Адміністративне право}

України «Про затвердження типового статуту громадського формування 3 охорони громадського порядку і державного кордону, описів зразків бланка посвідчення і нарукавної пов'язки члена такого формування» [6]; наказів МВС України [7].

Громадські формування з охорони громадського порядку і державного кордону можуть бути створені на засадах громадської самодіяльності як зведені загони громадських формувань, спеціалізовані загони (групи) сприяння Національній поліції та Державній прикордонній службі України, асоціації громадських формувань тощо. Тобто основними формами самоорганізації громадян щодо охорони громадського порядку є зведені загони громадських формувань, спеціалізовані загони (групи), асоціації громадських формувань. Інші форми участі громадян в охороні правопорядку не деталізовані. Формально немає перепон для діяльності у вигляді неприбуткових громадських організацій чим і користуються так звані «активісти». Такі організації, з одного боку декларують, що вони створені для охорони громадського порядку та громадського спокою, а з іншого - посилаються на Закон України «Про громадські об’єднання», який не передбачає вимог узгоджувати створення та діяльність таких форм самоорганізації населення з Національною поліцією та Державною прикордонною службою.

Закон України «Про участь громадян в охороні громадського порядку та державного кордону» визначає суб'єктів ініціювання створення громадських формувань 3 охорони громадського порядку. Серед них виділено: а) громадяни, які за власною ініціативою створюють громадські формування за місцем проживання, роботи чи навчання; б) органи місцевого самоврядування, окремі територіальні громади, місцеві державні адміністрації, які ухвалюють рішення про необхідність створення зазначених формувань для охорони правопорядку на відповідній території; в) органи Національної поліції України та Державної прикордонної служби; г) спільне ініціювання органами місцевого самоврядування, окремими територіальними громадами, місцевими державними адміністраціями 3 територіальними підрозділами Національної поліції в рамках адміністративних договорів, що укладаються між даними суб'єктами.

Зазначений вище закон вступив у силу ще у 2000 року за часів президентства $\lambda$ eоніда Кучми. Очевидно, за цей час положення цього закону морально застаріли та не відповідають міжнародним стандартам. Таким чином, нині дійсна форма участі громадян в охороні громадського порядку i державного кордону має багато негативних факторів. Громадські формування з охорони громадського порядку і державного кордону перетворюються на кишенькові армії органів місцевого самоврядування чи політичних діячів або діють на власний розсуд, поза контролем органів Національної поліції і підрозділів Державної прикордонної служби України [8].

Окрім того, результати аналізу його окремих норм показали, що закон не забезпечує в повній мірі дотримання прав людини і можуть призвести до небезпечних зловживань своїми повноваженнями як органів Національної поліції України та Державної прикордонної служби України, так і членами вищевказаних громадських формувань. Адже обсяг повноважень членів громадських формувань рівноцінний обсягу повноважень посадових осіб Національної поліції України і Державної прикордонної служби України, тому фактично громадські формування з охорони громадського порядку і державного кордону виконують функції держави, не маючи при цьому необхідної кваліфікації.

Крім того, зазначений закон не визначає саме поняття «громадського формування», в інших законодавчих актах цей термін взагалі не використовуються. Законом України «Про громадський об'єднання» передбачено дві форми таких об'єднань: громадські організації та громадські спілки. Фактично відсутне нормативне закріплення порядку організації взаємодії таких формувань 3 правоохоронними органами. Це, у свою чергу, є вкрай важливим, адже Закон України «Про участь громадян в охороні громадського порядку та державного кордону» дозволяє таким громадським формуванням діяти винятково за погодженням органів 
Національної поліції та Державної прикордонною служби. I будь-яка інша діяльність матиме ознаки протизаконної.

Усі форми та методи роботи громадських формувань 3 охорони громадського порядку і державного кордону здійснюється під контролем органів Національної поліції, підрозділів Державної прикордонної служби України (ч. 1 ст. 11 Закону). До таких форм віднесено: 1) спільне 3 поліцейськими, прикордонниками патрулювання і виставлення постів на вулицях, майданах, залізничних вокзалах, в аеропортах, морських і річкових портах, у місцях компактного проживання громадян, розташування підприємств, установ, організацій, навчальних закладів, а також у місцях можливої появи порушників кордону в межах району, що контролюється Державною прикордонною службою України, прикордонної смуги; участі в забезпеченні охорони громадського порядку під час проведення масових заходів, погоджених у випадках, передбачених законом, $з$ виконавчими органами місцевого самоврядування; 2) проведення разом 3 прикордонниками огляду на маршрутах можливого руху порушників державного кордону, місць їх укриття, транспортних засобів, суміжної 3 державним кордоном місцевості з метою встановлення причин та умов перебування невідомих осіб; 3) участь у заходах правоохоронних органів, спрямованих на боротьбу з окремими видами правопорушень.

Однак ані органи Національної поліції, ані Державної прикордонної служби не мають нормативно-правового регулювання реалізації такої процедурної діяльності. Ще більш не визначеним $є$ роль місцевих державних адміністрацій, органів місцевого самоврядування у взаємодії 3 громадськими формуваннями 3 охорони громадського порядку та кордону. Закон вказує лише, що ці суб'єкти здійснюють координацію діяльності громадських формувань та «надають всіляку допомогу та підтримку у створенні громадських формувань 3 охорони громадського порядку і державного кордону». Інші положення цього Закону щодо обов'язків місцевих державних адміністрацій та органів місцевого самоврядування є також суто абстрактними й не містять способів реалізації цих обов’ язків.

Закон №1835-III від 22.06.2000 «Про громадські формування 3 охорони громадського порядку та державного кордону» фактично повторюе всі положення Указу Президії Верховної Ради СРСР «Про основні обов'язки та права народних дружин по охороні громадського порядку» від 27.05.1974 р. [9]. Ми можемо спостерігати майже точне копіювання значної кількості положень, що стосуються прав та обов'язків добровільних народних дружин, які були закріплені у радянському законодавстві. Більшість відмінностей $є$ незначними або взагалі неактуальними в сучасних умовах (наприклад, право використання засобів телефонного зв'язку підприємств, установ, організацій у службових цілях. Чи не єдиною важливою відмінністю даних нормативноправових актів є питання підпорядкування таких громадських формувань. Якщо за чинним законодавством ці громадські формування формально не підпорядковані органам виконавчої влади, а лише мають діяти у взаємодії з Національною поліцією та Державною прикордонною службою, то за радянським законодавством вони знаходилися у підпорядкуванні районних, міських, селищних та сільських Рад депутатів трудящих та їхніх виконавчих комітетів. При цьому самі добровільні народні дружини, як свідчить їхня назва, створювалися на окремих підприємствах, установах, організаціях на добровільних засадах. Однак слід зазначити, що радянська правова система передбачала жорстку вертикаль влади і ніщо в країні не могло діяти поза жорстким контролем з боку держави.

Діяльність усіх суб'єктів, які зазначені в Законі України «Про громадські формування $з$ охорони громадського порядку та державного кордону», передбачає їхню спільну реалізацію разом з органами та підрозділами як Національної поліції, так і державної прикордонної служби. За своєю сутністю, діяльність зазначених громадських формувань не може мати ізольований та самостійний характер, а має здійснюватися винятково у співпраці 3 державними правоохоронними органами. Уся система побудована 


\section{Адміністративне право}

на радянській системі свідомої допомоги громадян державним структурам. Однак така допомога 6 можливою лише за наявності реальної довіри з боку громадськості. Не можна сподіватися на допомогу за мінімальної довіри населення до поліції. Майже всі соціологічні дослідження, які проводили в останні роки існування міліції, свідчили про вкрай низький рівень довіри населення до даного правоохоронного органу. При цьому спостерігалося стійке падіння рівня довіри 35 відсотків в 2010 до 0,8 відсотки в 2014 [10]. Ситуація, за думкою реформаторів, мала змінитися із реорганізацією міліції в «нову поліцію». Запровадження оновленої патрульної служби надало певний аванс довіри з боку населення. Однак уже протягом одного року позитивні очікування населення змінилися на протилежні. Яскрава картинка, яка подавалася в засобах масової інформації, ніяк не корелювалася з реальним станом громадської безпеки в країні. Корупційні та інші скандали майже повністю знищили залишки авторитету державних правоохоронних органів.

У зв'язку з викладеним, говорити про дієву систему взаємодії населення та державних правоохоронних органів на цьому етапі говорити не можна. Необхідним є відновлення довіри населення до поліції. Основною умовою такого відновлення $є$ чітке дотримання норм закону з боку працівників поліції, неухильне дотримання прав і свобод громадян, активна профорієнтаційна робота. Необхідно, щоб поліція дійсно виконувала сервісну функцію щодо населення. Використання поліції виключно як карального органу лише поглиблюватиме кризу неприйняття ії діяльності з боку населення.

Звісно, не можна залишати поза увагою всі ті негативні соціально-економічні зміни, яких зазнала наша країна протягом останніх десятиліть. Злам економічної моделі існування країни, «дикий капіталізм», первинне накопичення капіталу, свавілля чиновників не могли не позначитися на соціальному устрої. За радянських часів модель залучення громадськості до охорони громадського порядку базувалася на виробничому принципі - добровільні народні дружини створювалися здебільшого на під- приємствах чи в окремих державних організаціях. Активно ця модель реалізовулася й в навчальних закладах, в домоуправліннях та квартальних комітетах. Існувала чітка система стимулювання участі громадян в охороні громадського порядку. Звісно, за адміністративно-командної системи не було особливих проблем із організацією сприяння участі громадян в охороні громадського порядку з боку керівництва підприємств, установ, організацій. Це було пов'язано 3 тим, що, по суті, всі підприємства, установи й організації були державними. На керівництво зазначених підприємств був покладений обов'язок матеріального забезпечення добровільних народних дружин. Зокрема, для штабів ДНД виділялися окремі приміщення, необхідні меблі, інше матеріальне забезпечення. Добровільним народним дружинам для виконання їхніх завдань виділявся транспорт та засоби зв'язку. Окрім звичайних моральних заохочень за активну участь у боротьбі з правопорушеннями, народним дружинникам надавалися додаткові відпустки строком до трьох діб, переважного права на одержання жилої площі надання пільгової путівки до санаторію або будинку відпочинку тощо. Зрозуміло, що такий спосіб заохочення майже неможливо реалізувати в умовах жорсткої ринкової економіки. Власники підприємств не мають бажання витрачати додаткові кошти на те, що безпосередньо не приносить прибутку, й, відповідно, не зацікавлені у підтриманні роботи громадських формувань 3 охорони громадського порядку.

Іншою складовою, яка забезпечувала дієвість системи добровільних народних дружин, була єдина партійна система, яка мала свої представництва й осередки майже у всіх підприємствах і організаціях, навчальних закладах тощо. Ця партійна система здійснювала певний тиск як на керівництво підприємств, так і на працівників. Ідеалізована «добровільність» добровільних народних дружин здебільшого мала примусовий характер. Існувала система розрахунків на участь певної кількості осіб у ДНД на кожному підприємстві.

Зазначені вище радянські способи заохочення залучення громадян до охорони 
громадського порядку неможливо застосувати в нинішніх умовах. У зв’язку з цим необхідно відшукувати нові способи такого заохочення. Насамперед, необхідно вирішити дві глобальні проблеми: недосконалість правового регулювання діяльності громадських формувань 3 охорони громадського порядку, а також низький рівень довіри до поліції. Вирішення проблеми нормативного регулювання залежить лише від політичної волі й не вимагає значного часу. У той же час проблема довіри населення до державної правоохоронної системи є вкрай складною. Її неможливо вирішити кількома законами - це довготривалий і складний процес. Якщо раніше наголос робився на робітників підприємств, нині варто звернути увагу, насамперед, на навчальні заклади. Студентство є найбільш активною категорією населення. Правильно поставлена агітаційна робота серед студентства у поєднанні 3 правовим вихованням може дати швидший результат. 3 цього приводу слушною 6 пропозиція С. С. Юрка про залучення студентів та курсантів навчальних закладів, що займаються підготовкою кадрів працівників поліції як громадських помічників поліції та членів відповідних студентських дружин при такого роду закладах [11, с. 185]. Такий підхід, фактично, зможе стати елементом профорієнтаційної роботи національної поліції щодо підбору кандидатів на службу в органи Національної поліції. Основними суб’єктами такої діяльності мають бути вищі навчальні заклади із специфічними умовами навчання, які знаходяться у підпорядкуванні МВС України. Такі навчальні заклади мають значний досвід у підготовці працівників правоохоронної сфери. Правова підготовка студентів щодо порядку здійснення правоохоронних заходів, навички складання процесуальних документів, практика спільного патрулювання з працівниками поліції збільшуватиме кількість осіб, які матимуть змогу реально виконувати правоохоронні функції й стати в подальшому правоохоронцями.

\section{Висновки}

Якщо детально проаналізувати досвід залучення громадян до охорони громадського порядку в нашій країні, інших країнах, не можна стверджувати на недоцільності такої практики. Це не залишки «совка», якого слід позбутися. Не можна відкидати досвід, який був набутий за часи перебування України в складі СРСР. Визнавати якісь факти та практику лише на підставі того, що це використовувалось радянською владою, є ознакою обмеженості у сприйнятті дійсності. У багатьох країнах світу існує практика залучення громадян до охорони громадського порядку та спільної діяльності $з$ правоохоронними органами. Зокрема, Японія останні десять років впроваджує саме радянський досвід залучення громадян до такої діяльності. Окрім аналогів добровільних народних дружин, у Японії активно розвивається діяльність аналогів квартальних комітетів, які існували в нашій країні.

Рівень залучення громадян до співпраці 3 правоохоронними органами щодо забезпечення правопорядку та протидії злочинності є еталоном розвитку в країні громадянського суспільства. Активна громадянська позиція, яка підкріплюється довірою до державних інституцій, може якісно змінити на краще співжиття всіх членів суспільства.

\section{Аітература}

1. Про участь громадян в охороні громадського порядку i державного кордону: Закон України від 22.06.2000 № 1835III. URL: http://zakon3.rada.gov.ua/laws/ show/1835-14

2. Профілактика злочинів: підручник / [О. М. Джужа, В. В. Василевич, О. Ф. Гіда та ін.]; а заг.ред. докт. юрид. наук, проф.О.М. Джужи. К.: Атіка, 2011. 720 с.

3. Про громадські об'єднання: Закон України від 22.03.2012 // Відомості Верховної Ради України. 2013. № 1. Ст. 1. URL: https://zakon.rada.gov.ua/laws/show/4572-17

4. Про органи самоорганізації населення: Закон України від 11.07.2001№ 2625-III. URL: http://zakon.rada.gov.ua/ laws/show/2625-14

5. Кодекс України про адміністративні правопорушення: Кодекс України від 07.12.1984 № 8073-X. URL:http://zakon.rada. gov.ua/laws/show/80731-10

6. Про затвердження типового статуту громадського формування 3 охорони гро- 


\section{Адміністративне право}

\section{АНОТАЦІЯ}

у статті проаналізовано сучасний стан правового регулювання порядку залучення громадян до охорони громадсъкого порядку в Украіні. Відзначається декларативний та безсистемний підхід щодо залучення громадян до охорони правопорядку. Розглянуто спірні положення Закону України «Про участь громадян в охороні громадсъкого порядку та державного кордону». Звернуто увагу на відсутність правового визначення самого поняття «громадсъкого бормування», яке не використовується в інших законодавчих актах. Фактично відсутне нормативне закріплення порядку організаиї взаємодії таких формувань з правоохоронними органами. Діяльність зазначених громадських бормувань дозволяється винятково за погодженням органів Національної полічї та Державної прикордонною служби, будь-яка інша діяльність матиме ознаки протизаконної. Наголошено, що за своєю сутністю діяльність громадських бормувань з охорони громадсъкого порядку не може мати ізольований та самостійний характер, а має здійснюватися виключно у співпрачі з державними правоохоронними органами. Визначено основні способи стимулювання участі громадян в охороні громадсъкого порядку та визначено перспективи такої діяльності в нашій краӥні.

Ключові слова: охорона громадсъкого порядку, правоохоронні органи, борми взаємодї, громадські бормування.

мадського порядку і державного кордону, описів зразків бланка посвідчення і нарукавної пов'язки члена такого формування: Постанова Кабінету міністрів України від 20.12.2000 // Офіційний вісник України. 2000. № 52. ст. 2259. URL: https://zakon.rada. gov.ua/laws/show/1872-2000-\%D0\%BF

7. Про затвердження Інструкції про порядок придбання, видачі та зберігання спеціальних засобів членів громадських формувань з охорони громадського порядку : Наказ МВС України від 27.04.2007 // Офіційний вісник України. 2009. № 55. ст. 1947. URL: https://zakon.rada.gov.ua/laws/show/ z0644-09

\section{SUMMARY}

The article analyses present state of legal regulation of citizens' involvement in community policing in Ukraine. It ascertains declarative character and haphazard approach to citizens' involvement in community policing. The article reviews controversial provisions of the Statute of Ukraine "On Citizens' Participation in Community Policing and Protection of the State Border". It emphasizes the lack of definition of community groups that is not used in other legislative acts. It also outlines the lack of legislative regulation of collaboration of such groups with law enforcement agencies. The activity of such community groups is legitimate only upon reconciliation with organs of the National Police and the State Border Service; any other activity would be considered illegal. The article emphasizes that according to its nature activity of community groups must not be incoherent and independent. It must be conducted exceptionally on the collaborative bases with state law enforcement agencies. The article outlines major ways of encouraging citizens' participation in community policing and uncovers the perspectives of such activity in our state.

Key words: community policing, law enforcement agencies, forms of collaboration, community groups.

8. Пояснювальна записка до проекту Закону України «Про внесення змін до деяких законодавчих актів України щодо удосконалення окремих положень 3 питань охорони громадського порядку і державного кордону». URL: http://w1.cl.rada.gov.ua/ pls/zweb2/webproc34?id=\&pf3511=63749\& pf35401 = 451046

9. Об основных обязанностях и правах добровольных народных дружин по охране общественного порядка : Указ Президиума Верховного Совета СССР от 20 мая 1974 года URL: http://pravo.gov.ru

10. Питання реформування органів внутрішніх справ України: Розпорядження КМУ від 22.10.2010 // Офіційний вісник України. 2014. № 96 Ст. 2767.

11. Юрко С. С. Недержавна охоронна i правоохоронна діяльність в Україні: дис. ... канд. юрид. наук. 12.00.10. Одеса, 2017. 252 с. 


\title{
ПРАВОВЕ РЕГУЛЮВАННЯ СТАДӤ ПЦДГОТОВКИ ДО РОЗГЛЯДУ СПРАВИ ПРО АДМННСТРАТИВНЕ ПРАВОПОРУШЕННЯ В СУДАХ
}

\author{
БОРТНИК Надія Петрівна - доктор юридичних наук, професор, завідувач \\ кафедри адміністративного та інформаційного права Національного університету \\ «Львівська політехніка» \\ ДМИТРИК Юрій Іванович - кандидат юридичних наук, доцент, доцент \\ кафедри адміністративного та інформаційного права Національного університету \\ «Јьвівська політехніка»
}

DOI 10.32782/LAW.2020.3.7

\begin{abstract}
В статье проводится анализ правового регулирования стадии подготовки к рассмотрению дела об административном правонарушении в судах общей юрисдикции c использованием метода сравнительного законодательства, формально-юридического и общенаучнъх методов исследования правовых явлений. На основании анализа действующего Кодекса Украинъ об административных правонарушениях рассмотрено нормв административно-процессуального регулирования стадии подготовки к рассмотрению дела об административном правонарушении в судах общей юрисдикици, органах, имеющзих административно-юрисдикиионную компетениию, должностнъими лицами уполномоченнълми рассматривать дела об административных правонарушениях. На основании анализа сделан въгвод о минимальном объеме административно-процессуального регулирования стадии, что исследуется.

Ключевъе слова: дело об административном правонарушении; стадия административно-деликтного производства; подготовки к рассмотрению, суд.
\end{abstract}

Постановка проблеми

Завдання підвищення ефективності провадження у справах про адміністративні правопорушення передбачають вирішення питань недосконалості правової регламентації його стадій. Підготовка до розгляду справи про адміністративне правопорушен- ня відіграє важливу роль у провадженні у справах про адміністративні правопорушення, оскільки вирішуються питання, що впливають на подальший хід справи. Від якості проведення процесуальних дій на стадії підготовки до розгляду справи залежить підсумкове рішення по суті справи, а також те наскільки ефективно будуть реалізовані завдання провадження у справах про адміністративні правопорушення, всебічне, повне, об'єктивне, своєчасне з'ясування обставин, вирішення відповідно до закону. Практика реалізації цієї стадії не завжди демонструє здатність ефективного захисту прав і законних інтересів учасників адміністративно-процесуальних відносин.

Діяльність суду як суб'єкта адміністративно-деліктної юрисдикції у контексті стадій розгляду справ про адміністративні правопорушення, висвітлили у наукових працях вчені: В. Б. Авер'янов, О. О. Банчук, Ю. П. Битяк, В. В. Богуцький, І. В. Бойко, Е. Ф. Демський, Е. В. Додін, О. Т. Зима, В. В. Зуй, А. В. Кишинський, Т. О. Коломоєць, В. К. Колпаков, А. Т. Комзюк, С. О. Короєд, О. В. Кузьменко, Д. М. Аук'янець, О. І. Миколенко, О. І. Остапенко, В. $\curlywedge$. Ортинський, Н. Б. Писаренко, В. М. Скавронік, О. М. Собовий, Н. В. Янюк та інші.

Мета статті - аналіз правового регулювання стадії підготовки до розгляду справи про адміністративне правопорушення в судах. 


\section{Адміністративне право}

Виклад основного матеріалу

Істотні зміни, що відбулися в Україні на початку 90-х років, зумовили нові напрями в розвитку законодавства про адміністративну відповідальність так, що багато норм Кодексу УРСР про адміністративні правопорушення виявилися недіючими, оскільки Конституція України сформувала нову систему органів публічної влади, встановила нові принципи економічної діяльності, проголосила пріоритет прав і свобод людини та громадянина, визначила нові напрями розвитку законодавства стосовно мети правової держави.

У результаті було внесено низку змін і доповнень до Кодексу про адміністративні правопорушення. Встановлено порядок розгляду клопотань осіб, які беруть участь у справі; особа, яка притягається до адміністративної відповідальності, потерпілий отримали право користуватися допомогою захисника або представника в особі адвоката або іншої особи; в осіб, які беруть участь у справі, виникло право відводу судді, органу, посадової особи, уповноваженого розглядати справу про адміністративне правопорушення; були визначені обставини, що виключають можливість розгляду справи суддею, членом колегіального органу, посадовою особою.

У чинному Кодексі України про адміністративні правопорушення (далі - КУпАП) знайшла відображення норма, згідно з якою законодавство про адміністративні правопорушення складається 3 норм, визначених у КУПАП, та норм, які встановлюються сільськими, селищними, міськими, обласними радами прийнятих відповідно до КУпАП.

3 огляду на це виникає закономірне питання про зміст такої категорії, як порядок провадження у справах про адміністративні правопорушення. Виходячи із значення слова «порядок» і юридичного контексту терміна, законодавець під категорією «порядок провадження у справах про адміністративні правопорушення» розуміє нормативне закріплення послідовного ходу провадження у справах про адміністративні правопорушення і правил його здійснення. У юридичній літературі позицій, що стосуються тлумачення цього поняття, практич- но мало, хоча відсутність роз'яснення з боку законодавця викликало окремі зауваження вчених у галузі адміністративного права.

Встановлення порядку реалізації стадії підготовки до розгляду справи про адміністративне правопорушення можливе тільки на рівні законодавства в КУпАП. Однак це не повною мірою відповідає дійсності.

Нині в КУПАП підготовка до розгляду справи про адміністративне правопорушення передбачається статтею 278 «Підготовка до розгляду справи про адміністративне правопорушення» Глави 22, присвяченої розгляду справи про адміністративне правопорушення загалом. Натомість,О. I. Остапенко, розглядаючи деякі питання розгляду справ про військові адміністративні правопорушення зазначає, що процедура підготовки до розгляду справи про адміністративне правопорушення регламентована нормами глави 22 КУПАП максимально лаконічно [1, с. 94]. Вона позбавлена стадій. Хоча багато процесуальних норм вимагають доопрацювання.

На відміну від Кодексу УРСР про адміністративні правопорушення, норми, що стосуються підготовки до розгляду, після внесення змін та доповнень до КУпАП у 2001 році, зазнали суттєвих змін: розширився перелік питань, що підлягають з'ясуванню, були уточнені деякі формулювання; судді отримали повноваження 3 розгляду справ про адміністративні правопорушення в межах компетенції; з'явилися норми, що гарантують дотримання прав і законних інтересів осіб, які беруть участь у провадженні, що сприяє об’єктивному з'ясуванню обставин кожної справи про адміністративне правопорушення; отримали регламентацію процесуальні акти, що виносяться при підготовці до розгляду справи про адміністративне правопорушення [2].

Однак, не дивлячись на це, суддя, орган, посадова особа, уповноважені на розгляд справи, у зв'язку з відсутністю детальної правової регламентації деяких аспектів підготовки до розгляду справи про адміністративне правопорушення змушені керуватися не положеннями КУпАП, а аналогією права та численними роз'ясненнями вищестоя- 
щих органів, які, на жаль, доволі часто суперечать один одному.

Правове регулювання підготовки до розгляду справи про адміністративне правопорушення на сучасному етапі розвитку законодавства викликає деякі труднощі. Загальна регламентація двох фактично самостійних стадій провадження у справах про адміністративні правопорушення - стадії підготовки до розгляду справи та розгляду справи, по суті, спричиняє серйозні наслідки та сприяє виникненню складнощів у практичній діяльності при їх розмежуванні, приводячи до помилок у правозастосуванні.

Головна мета стадії підготовки до розгляду справи - створення всіх необхідних умов для правильного та своєчасного розгляду і вирішення справи по суті, - повною мірою не досягається.

У результаті органам, які мають право ухвалювати рішення у справах про адміністративні правопорушення 3 метою роз'яснення деяких проблемних питань застосування норм КУПАП у частині підготовки до розгляду справи (і не тільки підготовки) доводиться вдаватися до розробки своїх підзаконних нормативно-правових актів.

Питання підготовки в частині, що не врегульована КУпАП, знайшли роз'яснення в Інструкції 3 оформлення матеріалів про адміністративні правопорушення в органах поліції, Інструкції 3 оформлення поліцейськими матеріалів про адміністративні правопорушення у сфері забезпечення безпеки дорожнього руху, зафіксовані не в автоматичному режимі, Інструкції з оформлення матеріалів про адміністративні правопорушення посадовими особами уповноважених органів 3 питань пробації, Тимчасових правилах розгляду справ про порушення антимонопольного законодавства України та низці інших нормативних актів різних відомств, наділених адміністративно-юрисдикційними повноваженнями $[3 ; 4 ; 5]$.

Для судів нижчих рівнів з метою забезпечення однаковості судової практики розробляються керівні роз'яснення та узагальнення Верховного Суду України, наприклад, «Про якість складання й оформлення судових рішень у кримінальних справах та справах про адміністративні правопорушення» тощо [6].

Навіть у суб'єктів, уповноважених розглядати справи про адміністративні правопорушення, не склалося єдиного підходу до порядку здійснення стадії підготовки до розгляду справи. Багато питань у них висвітлюється фрагментарно та не дозволяє сформувати повного уявлення в особи, яка застосовує право щодо правильного порядку здійснення зазначеної стадії.

Характер наведених вище актів не дозволяє усунути недосконалість та недостатність правового регулювання стадії підготовки до розгляду справи про адміністративне правопорушення, наявні в КУпАП.

Діючі інструкції та правила, прийняті органами, наділеними адміністративноюрисдикційними повноваженнями, не можуть повноцінно замінити законодавчого регулювання, принаймні при виконанні контрольної й охоронної функцій.

Виходячи 3 результатів аналізу положень відомчих актів, не вирішеними залишаються: необхідність обов'язкової участі (при розгляді справи судом) в судовому засіданні посадових осіб за власною ініціативою, ініціативою суду або осіб, які беруть участь у справі; порядок розгляду клопотань осіб, які беруть участь у провадженні у справі про адміністративне правопорушення; строк проведення підготовки до розгляду справи; необхідність вирішення питань про об'єднання двох або більше справ в одне провадження або виділення справи в окреме провадження.

Наукове співтовариство виділяє такі недоліки правового регулювання: відсутність регламентації порядку повідомлення учасників провадження у справах про адміністративні правопорушення; складності у визначенні підстав для повернення протоколу та матеріалів справи; відсутність рішення 3 питання про визначення підсудності справи за наявності декількох критеріїв та інші [7; 8].

Вважаємо, що необхідно виділити правовому регулюванню стадії підготовки до розгляду справи про адміністративне правопорушення окрему главу КУпАП, що дозволить більш детально регламентувати за- 


\section{Адміністративне право}

значені вище аспекти, які потребують нормативного уточнення та вирішення. Прикладом може слугувати Глава 3 «Підготовче провадження» Кодексу адміністративного судочинства України [9].

Деякі вчені в галузі адміністративного права та адміністративного процесу висловлюють думку про детальне врегулювання порядку розгляду справ про адміністративні правопорушення в судах загальної юрисдикції нормами єдиного Кодексу адміністративного судочинства. Швидше за все, така позиція складається, виходячи з того, що деякі автори в адміністративне судочинство включають провадження у справах про адміністративні правопорушення.

Конституційний Суд у низці постанов, розглядаючи різні аспекти адміністративної відповідальності, використовував поняття адміністративне судочинство. Однак, будучи прихильниками комплексного (на основі управлінського) підходу розуміння адміністративного процесу, вважаємо, що ця пропозиція не охоплює суддів, органів і посадових осіб, уповноважених на розгляд справи про адміністративне правопорушення.

На наш погляд, це може привести до дисонансу в правовому регулюванні, де суди загальної юрисдикції будуть діяти на підставі розроблених під них норм, а питання щодо порядку підготовки до розгляду справи іншими органами не будуть вирішені.

C. С. Гнатюк зазначає, що стадія розгляду та винесення постанови (рішення) у справі про адміністративний проступок - це система процесуальних дій, спрямованих на вивчення та оцінку матеріалів справи, встановлення об'єктивної істини та винесення постанови по суті справи. У ній можна визначити етапи: прийняття та підготовка справи до розгляду: вирішення питання про належність до компетенції, вивчення матеріалів справи, витребування необхідних додаткових матеріалів, сповіщення відповідних суб'єктів про час і місце розгляду справи, з'ясування, чи підлягають задоволенню заявлені клопотання [10, с. 127].

У науковій літературі можна зустріти пропозиції щодо закріплення в Кодексі адміністративного судочинства України однакових законодавчих дефініцій судово-ад- міністративної справи та процедури адміністративного судочинства, виключивши ці процедури з КУпАП, розробити та прийняти закон «Про адміністративне провадження», в якому співвідносно 3 нормами КАС можна визначити єдині вихідні засади адміністративно-процесуальної діяльності органів виконавчої влади та місцевого самоврядування, їх посадових осіб, інших органів, що наділені в установленому порядку адміністративно-процесуальними повноваженнями.

На нашу думку, зазначені пропозиції не впливають на концепцію чинного КУпАП. Необхідно нагадати про те, що адміністративна відповідальність була встановлена як відповідальність позасудова.

Пропонується також варіант, який передбачає роздільну кодифікацію матеріальних і процесуальних норм про адміністративну відповідальність. На нашу думку, немає необхідності в прийнятті окремих законодавчих актів, присвячених виключно провадженню у справах про адміністративні правопорушення, наприклад, пропонованих деякими вченими адміністративно-процесуального і адміністративно-деліктного виконавчого кодексів. Низка вчених вказує на потребу в новому кодифікованому акті на зміну чинного КУпАП 3 більш ємним і точним найменуванням, як Кодекс України про адміністративну відповідальність.

Водночас, еволюційна корекція норм, яка загалом витримала випробування практикою та часом і продемонструвала свою ефективність, не повинна підмінятися революційною заміною та демонтажем. Правильніше було б законодавцю уточнити формулювання вже чинних нормативних правил, а не доповнювати новими і одночасно не зрозумілими для осіб, які застосовують правові положення з практичної точки зору.

Виділення провадження у справах про адміністративні правопорушення в окремий самостійний адміністративно-процесуальний кодекс бачиться нераціональним, оскільки практика показує доцільність і необхідність закріплення матеріальних і процесуальних норм в одному нормативно-правовому акті. 
Варто зазначити, що аналогічного порядку дотримується більшість країн Европейського Союзу. Вони, як і КУпАП, регламентують питання адміністративних деліктів, видів покарань, стадій провадження. У них містяться положення про суб'єктів вчинення адміністративного делікту, з-поміж яких, поряд 3 фізичною особою, виділяються юридичні особи. Реформування адміністративно-правового механізму носить складний характер, але грунтується на досвіді країн-членів ЕС. Комплексний підхід до реформування адміністративно-правового механізму є найбільш обгрунтованим i ефективним в умовах періоду адаптації національного законодавства та реформування державного управління [11, с. 6006].

3 огляду на схожість багатьох характерних рис згаданих законів з КУпАП, накопичений значний досвід у вирішенні теоретичних і практичних проблем адміністративно-деліктного права, наявність законодавчої регламентації низки інститутів процесуального характеру, які в національному адміністративному процесі ще не настільки розвинені, вважаємо, що доцільно зберегти загальну структуру існуючого КУпАП, що передбачає одночасну регламентація матеріальних і процесуальних норм в єдиному кодифікованому акті.

\section{Висновки}

Підсумовуючи викладене вище, можемо констатувати, що метою підготовки до розгляду справи є створення всіх необхідних умов для правильного та своєчасного розгляду справи про адміністративне правопорушення по суті. Класифікація завдань стадії підготовки до розгляду справи в залежності від функцій підготовки до розгляду справи про адміністративне правопорушення в провадженні у справах про адміністративні правопорушення включає перевірочні та підготовчі, залежно від реалізації загальних завдань провадження у справах про адміністративні правопорушення та сприяє: вирішенню справи відповідно до закону, об'єктивному та повному з'ясуванню обставин кожної справи. Під встановленим порядком провадження у справах про адміністративні правопорушення варто розуміти нормативне закріплення послідовного ходу провадження у справах про адміністративні правопорушення та правил його здійснення. Аналіз положень чинного законодавства свідчить про недостатність і недосконалість правового регулювання підготовки до розгляду справи про адміністративне правопорушення. 3 метою детального нормативного уточнення вирішення встановлених проблем у правовому регулюванні підготовки до розгляду справи, враховуючи теоретико-правові підстави для ӥі характеристики як окремої стадії провадження, необхідно внести зміни в структуру чинного КУпАП за допомогою введення окремої глави, присвяченої цим питанням. Існує необхідність введення правила, яке встановлює, що підготовка до розгляду справи про адміністративне правопорушення здійснюється тільки на підставі положень КУпАП не залежно від того, яким суддею, органом, посадовою особою воно підлягає розгляду.

\section{入ітература}

1. Остапенко О. І. Деякі питання розгляду справ про військові адміністративні правопорушення. Науковий вісний Наиіонального Університету «Аьвівсъка політехніка». 2016. № 855. C. 93-99.

2. Про внесення змін до Кодексу України про адміністративні правопорушення: Закон України від 05.04.2001 р. № 2342III. URL.: https://zakon.rada.gov.ua/laws/ show/2342-14\#Text

3. Про затвердження Інструкції з оформлення матеріалів про адміністративні правопорушення в органах поліції: Наказ MBC України від 06.11.2015 р. № 1376. URL: https://zakon.rada.gov.ua/laws/show/z149615\#Text

4. Про затвердження Інструкції з оформлення поліцейськими матеріалів про адміністративні правопорушення у сфері забезпечення безпеки дорожнього руху, зафіксовані не в автоматичному режимі: Наказ МBC України від 07.11.2015 р. № 1395. URL: https://zakon.rada.gov.ua/laws/show/z140815\# Text

5. Про затвердження Тимчасових правил справ про порушення антимонопольного законодавства України: Розпорядження 


\section{Адміністративне право}

у статті проводиться аналіз правового регулювання стадї підготовки до розгляду справи про адміністративне правопорушення в судах загальної юрисдикиій з використанням методу порівняльного законодавства, бормально-юридичного та загальнонаукових методів дослідження правових явищ. На підставі аналізу чинного Кодексу України про адміністративні правопорушення розглянуто норми адміністративно-процесуального регулювання стадій підготовки до розгляду справи про адміністративне правопорушення в судах загальної юрисдикиій, органах, що мають адміністративно-юрисдикиійну компетениію, посадовими особами уповноваженими розглядати справи про адміністративні правопорушення. На підставі аналізу зроблено висновок про мінімальний обсяг адміністративно-процесуального регулювання стадї, що досліджусться.

Ключові слова: справа про адміністративне правопорушення; стадія адміністративноделіктного провадження; підготовки до розгляду, суд.

Антимонопольного комітету від 19.04.1994 р.№ 5. URL: https://zakon.rada.gov.ua/laws/ show/z0090-94\#Text

6. Про якість складання й оформлення судових рішень у кримінальних справах та справах про адміністративні правопорушення: Узагальнення Верховного Суду України від 01.08.2004 р. URL: https://zakon.rada.gov. ua/laws/show/n0058700-04\#Text

7. Денисюк I. I. Деякі питання підготовки до судового розгляду справ про екологічні адміністративні правопорушення. Юридичний електронний науковий журнал. 2018. № 1. С. 72-75.

8. Глибко О. В. Правові засади розгляду судами справ про адміністративні правопорушення: дис. ... канд. юрид. наук: спец.: 12.00.07. Харків. 2017. 207 с.

9. Кодекс адміністративного судочинства України: Закон України від 06/07/2005 р.№ 2747-IV. URL: https://zakon.rada.gov.ua/ laws/card/2747-15/conv

10. Гнатюк С.С. Провадження в справах про адміністративні проступки: проблем-
The article analyzes the legal regulation of the stage of preparation for consideration of a case on an administrative offense in courts of general jurisdiction using the method of comparative law, formal law and general scientific methods of research of legal phenomena. Based on the analysis of the current Code of Ukraine on Administrative Offenses, the norms of administrative-procedural regulation of the stage of preparation for consideration of a case on an administrative offense in courts of general jurisdiction, bodies with administrative jurisdiction, officials authorized to consider cases on administrative offenses are considered. Based on the analysis, a conclusion is made about the minimum amount of administrative and procedural regulation of the stage under study. It is noted that the purpose of preparation for consideration of the case is to create all the necessary conditions for the correct and timely consideration of the case of an administrative offense on the merits. Under the established procedure for proceedings in cases of administrative offenses, it is expedient to consider the normative consolidation of the consistent course of proceedings in cases of administrative offenses and the rules of implementation. In order to clarify in detail the solution of the established problems in the legal regulation of preparation for consideration of the case, taking into account the theoretical and legal grounds for its characterization as a separate stage of proceedings, it is necessary to make changes in the structure of the current Code of Administrative Offenses. There is a need to introduce a rule that establishes that the preparation for consideration of a case on an administrative offense is carried out only on the basis of the provisions of the Code of Administrative Offenses, regardless of which judge, body, official is considered.

Key words: case on administrative offense; stage of administrative tort proceedings; preparation for consideration, court.

ні питання структури: монографія. Аьвів: АьвДУВС, 2011. 156 с.

11. Ковалів М., Есімов С., Крамар Р. Скриньковський Р. Перспективи реформування організаційно-правового механізму забезпечення прав і свобод людини та громадянина. Traektoriâ Nauki. 2017. Vol. 3,№. 10. P. 6001-6008. 


\title{
ПРИНЦИПИ ЮРИДИЧНОӤ ВІДПОВІДАЛЬНОСТІ ЗА ПРАВОПОРУШЕННЯ У СФЕРІ ЗАБЕЗПЕЧЕННЯ ІНФОРМАЦІЙНОӤ БЕЗПЕКИ
}

\begin{abstract}
ПАРПАН Уляна Михайлівна - доктор юридичних наук, доцент, професор кафедри адміністративного та інформаційного права Навчально-наукового інституту права, психології та інноваційної освіти Національного університету «Львівська політехніка»

МАЛЕЦЬ Марта Романівна - асистент кафедри адміністративного та інформаційного права Навчально-наукового інституту права, психології та інноваційної освіти Національного університету «Львівська політехніка»

ВІТИК Орест Дмитрович - ЗВО «Львівський університет бізнесу та права» УДК 342.92.2:343.346.8

DOI 10.32782/LAW.2020.3.8
\end{abstract}

В статье исследуются приниипь юридической ответственности за правонарушения в сбере обеспечения инбормачионной безопасности через философский и специально-юридический аспектьл. Анализ научной литературъ позволяет въделить несколько подходов к пониманию юридической ответственности в сбере обеспечения информаичонной безопасности, воплощают личностнъий и государственно-властный подходъ, ито обусловлено общеправовъми, межотраслевылм и отраслевыли приниипами. Категория принципь в сбере обеспечения информационной безопасности позволяет наиболее точно передать правовую природу юридической ответственности, в связи с чем внимание уделено характернълм чертам, соотношением с понятием «информачионнве права» через категорию «инбормационная безопасность». Въиделеннъие универсальнъие признаки принципов, которве воплощают правовую природу юридической ответственности независимо от подхода к определению.

Ключевъие слова: юридическая ответственность, инбормационная безопасность, принципъ, правонарушения, кибербезопасность, инбормационная инфраструктура.

Постановка проблеми

Стрімкий розвиток інформаційно-комунікаційних технологій, інформатизація та цифровізація не тільки всіх сфер життєдіяльності, а й окремих напрямів економіки, 3 одного боку, сприяють розвитку інформаційного суспільства, з іншого? створюють умови для виникнення нових викликів і загроз для інформаційної безпеки в цифровому середовищі та інформаційному просторі. 3 метою досягнення сталого розвитку сучасного світу та інформаційного простору, всі країни повинні консолідувати зусилля з розробки нових інструментів забезпечення міжнародної інформаційної безпеки, продовжувати вдосконалювати національне законодавства та зміцнювати міжнародну співпрацю.

\section{Стан дослідження}

Важливе значення для розробки проблеми мали праці вчених-правознавців: В. Б. Авер'янова, О. Ф. Андрійко, А. І. Берлача, О. П. Віхрова, П. В. Діхтієвського, І. С. Гриценка, Е. В. Додіна, Р. А. Калюжного, С. В. Ківалова, А. А. Козловського, М. І. Козюбри, Т. О. Коломоєць, В. К. Колпакова, О. В. Кузьменко, В. І. Курила, Е. В. Курінного, Р. С. Мельника, В. Я. Настюка, О. І. Остапенка, В. А. Ортинського, А. О. Селіванова, О. І. Харитонової, В. В. Цвєткова, Я. М. Шевченко, Ю. С. Шемчушенка та інших.

Мета статті - дослідження принципів юридичної відповідальності за правопорушення е сфері забезпечення інформаційної безпеки.

Виклад основного матеріалу

Одним з основних завдань, що сприяють досягненню інформаційної безпеки України, є формування системи інформаційної безпеки не тільки на глобальному рівні, а й у 


\section{Адміністративне право}

форматах міждержавного співробітництва в рамках Європейського Союзу та ПівнічноАтлантичного альянсу. Виходячи 3 цього, актуальним $€$ дослідження питання про роль принципів правового забезпечення інформаційної безпеки в інформаційному просторі та цифровому середовищі.

Значення загальноправових, галузевих i міжгалузевих принципів сьогодні є не менш актуальним, аніж після Другої світової війни, коли було сформовано сучасну систему міжнародної безпеки та створено Організацію Об'єднаних Націй.

О. В. Зайчук вказує, що принципи права - це ідеї про те, як людське товариство в разі ефективної адаптації до конкретної поточної ситуації може бути організоване за допомогою права найкращим чином, із забезпеченням гідного в поточній і в довгостроковій перспективі існування кожного індивіда, готового слідувати певній моделі поведінки, 3 оптимальною організацією приватної та публічної сфер, покликаної сприяти гідному існуванню, з профілактикою та мінімізацією особистих і групових конфліктів і оптимальним виправленням наслідків [1, с. 22].

Модель соціальної поведінки, рекомендована об'єктивним принципом, повинна розумітися як абсолютно оптимальна для кожного з представників людства. Вона максимально органічно відповідає людській природі і тільки дотримання здатне забезпечити людині та суспільству кращі з можливих наслідків індивідуальних або групових рішень і дій.

Необхідно зауважити, що сьогодні єдина система принципів інформаційної безпеки на доктринальному та нормативному рівні ще не сформована. У цьому контексті,T. С. Перун зазначає, що принципи інформаційного права повинні забезпечувати гармонійну взаємодію різних суб'єктів: власників інформаційних ресурсів й інформаційних систем, держави та споживачів інформаційних послуг, а також безпосередньо інформаційних технологій та інформаційних ресурсів, призначених для забезпечення функціонування інформаційних процесів, зокрема забезпечення створення, поширення, використання, систематизації, збереження і знищення інформації [2, с. 104]. 3 огляду на те, що принципи як основні засади створюють фундамент правового регулювання, їх можна класифікувати, використовуючи класичний підхід, у такий спосіб.

1. Загальноправові приниипи інбормачійного права, які одночасно є універсальними для інших галузей права.

До них відносяться законність, рівність усіх перед законом і судом, справедливість, гуманізм і демократизм. Важливим кроком для розвитку права, загальних принципів і людства є Загальна декларація прав людини, прийнята 10 грудня 1948 року Генеральною Асамблеєю ООН, де міститься основа для базового принципу інформаційного права шукати, одержувати, поширювати інформацію й ідеї будь-якими засобами незалежно від державних кордонів [3].

Подібні положення містяться в Міжнародному пакті про громадянські та політичні права, ухваленому 16 грудня 1966 Резолюцією 2200 (XXI) на 1496-му пленарному засіданні Генеральної Асамблеї ООН, з яких випливає, що користування такими правами накладає особливу відповідальність, яка повинна бути встановлена законом [4].

Принципи права є інструментом системного, телеологічного, логічного тлумачення права, подолання колізій та прогалин у праві, створення в цих умовах норм права. Ці конституційно-закріплені принципи мають ключове значення для подальшого розвитку науки інформаційного права та регулювання правового забезпечення інформаційної безпеки.

Принцип рівності при забезпеченні інформаційної безпеки передбачає рівність усіх перед законом при реалізації прав на безпечне інформаційне середовище, безпечні технології, а стосовно відповідальності - рівність при застосуванні державою щодо суб'єкта примусових заходів при порушенні законодавства в цій сфері.

Принцип справедливості повинен забезпечувати відповідний рівень прав і свобод суб'єктів інформаційного обміну незалежно від їх статусу. Правове регулювання у цьому випадку має справедливо забезпечити інтереси особи, суспільства та держави на основі балансу між можливою поведінкою суб'єктів.

Принцип гуманізму у сфері інформаційної безпеки та відповідальності виражаєть- 
ся в необхідності пропорційності обмежень при забезпеченні інформаційної безпеки, заборону застосування технологій, що принижують людську гідність або призначення невідповідного покарання за делікт суб’єкту, який вчинив правопорушення в інформаційній сфері. Як зазначають автори монографії «Юридична відповідальність за правопорушення в інформаційній сфері та основи інформаційної деліктології», виникнення та поширення інформаційних деліктів зумовлено соціальними і технологічними трансформаціями в процесі становлення суспільства нового формату - інформаційного, глобального інформаційного, суспільства знань [5, с. 180].

2. Міжгалузеві принципи забезпечення інформачійної безпеки та інформачійного права загалом.

Передусім, це гласність, презумпція невинуватості, невідворотність покарання. До важливих міжгалузевих принципів можна віднести принцип довіри та принцип державного суверенітету.

Принцип довіри у сфері забезпечення інформаційної безпеки означає, що суб’єкти інформаційного обміну не завдадуть шкоди інформаційної безпеки іншим суб'єктам, інфраструктурі; їх дії матимуть позитивний характер для інших учасників, що виражається в дотриманні прав і свобод та надання взаємної допомоги при виникненні комп'ютерних інцидентів.

Принцип державного суверенітету в інформаційній сфері є одним із найбільш складних. Т. Ю. Ткачук у дисертаційному дослідження «Правове забезпечення інформаційної безпеки в умовах євроінтеграції України» пише, що основною метою державної інформаційної політики України є забезпечення: захисту інформаційного суверенітету держави (особливо захист національного інформаційного простору 3 інформаційним ресурсом і систем формування масової суспільної свідомості) [6, с. 354].

В умовах глобального інформаційного суспільства кордони держав виявилися розмитими, а з урахуванням непростих міжнародних і міждержавних відносин і сучасної архітектури співпраці у сфері інформаційної безпеки державний суверенітет в інформаційній сфері має безліч правових, політичних та культурних аспектів.
Збереження державного суверенітету в інформаційній сфері доцільно визначити, як можливість захисту держави в інформаційній сфері та самостійне визначення політики в інформаційній сфері, засноване на невтручанні в інформаційний суверенітет інших держав, аналогічно щодо інших держав до власного державного суверенітету в інформаційній сфері.

Цей принцип знайшов відображення в Резолюції Генеральної Асамблеї ООН від 5 грудня 2018 року «Досягнення у сфері інформатизації і телекомунікацій у контексті міжнародної безпеки», в якій довіра та безпека у використанні інформаційно-комунікаційних технологій віднесені до головних опор інформаційного суспільства, стійку глобальну культуру кібербезпеки необхідно заохочувати, формувати, розвивати і активно впроваджувати [7].

3. Галузеві приниипи інформаційного права, які сбормульовані в теорії інфбормачійного права та в нормативно-правових актах різного рівня.

Згідно зі ст. 3 Закону України «Про інформацію» від 2 жовтня 1992 року № 2657XII регулювання відносин у цій сфері базується на таких принципах: свобода пошуку, отримання, передачі, виробництва, поширення інформації будь-яким законним способом; відкритість інформації про діяльність державних органів і органів місцевого самоврядування та вільний доступ до такої інформації, крім випадків, встановлених законами. Вказані принципи співвідносяться з Цілями сталого розвитку України на період до 2030 року [8].

У Законі України «Про основні засади забезпечення кібербезпеки України» закріплено низку принципів, з яких до галузевих можна віднести: принцип безперервності, який передбачає цілодобове функціонування засобів захисту інформаційної інфраструктури від зовнішніх загроз і комп'ютерних атак; принцип комплексності, що означає застосування організаційно-правових, технічних засобів і методів, які в сукупності дозволяють забезпечувати безпеку критичної інформаційної інфраструктури України [9].

Принципом, що має практичне значення, є збереження традиційних для громадян форм отримання інформації. Наприклад, 


\section{Адміністративне право}

при функціонуванні інформаційної системи, метою якої $є$ надання адміністративних послуг в електронній формі.

Важливим міжнародним принципом, який може бути застосований у сфері інформаційної безпеки, є принцип загального обов'язку, закріплений у Декларації тисячоліття Організації Об’єднаних Націй, прийнятій резолюцією Генеральної Асамблеї ООН 8 вересня 2000 року № 55/2. Хоча цей принцип не торкається питань інформаційної безпеки безпосередньо, його дотримання сприяє стабілізації міжнародних відносин, зокрема у цій галузі [10].

Визначається цей принцип через необхідність усунення загроз міжнародній інформаційній безпеці. У разі впровадження та розвитку нейромереж принцип достовірності інформації буде вкрай важливим для прийняття на основі великих даних (big data) рішень, в основі яких буде аналіз інформації, проведений нейромережею.

Згідно з прогнозами прискорення темпів зростання та розвитку цивілізації буде відбуватися швидко. Розвиток штучного інтелекту та машинного навчання може дати поштовх для подальшого розвитку людства, але супроводжується певними ризиками. При такій динаміці розвитку технологій залишається відкритим питання про достатність тих основоположних засад, багато з яких були сформовані в римському праві.

Правові засади повинні впливати на статус, функціональний та правовий режим технології (гуманізм, справедливість, невідворотність покарання, пропорційність тощо), а не навпаки.

У найближчому майбутньому можливе формування нових принципів інформаційної безпеки. Проблеми цифрової економіки активно обговорюються в юридичному середовищі, органами державної влади, експертним співтовариством і суспільством загалом.

У 2018 році Кабінетом Міністрів України було схвалено Концепцію розвитку цифрової економіки та суспільства України на 2018-2020 роки та затверджено план заходів щодо іï реалізації, яка запустила масштабну системну програму розвитку економіки нового технологічного покоління - цифрової економіки. У Концепції розвитку цифрової економіки було визначено п'ять базових напрямів. До таких напрямів віднесено: нормативне регулювання, кадри, освіта, формування дослідницьких компетенцій і технічних напрацювань, інформаційна інфраструктура та інформаційна безпека [11].

Процес цифровізації, особливо використання низки цифрових технологій, породжує низку ризиків і загроз. У зв'язку з цим питання інформаційної безпеки практично в усіх інформаційних процесах стають ключовими і на національному, і на міжнародному рівнях. Правове регулювання Інтернет-відносин - це комплексна проблема не тільки юридичної науки, а й практики [12, с. 152].

Одним 3 важливих компонентів системи забезпечення інформаційної безпеки є інститут юридичної відповідальності. Він виконує низку функцій у цій системі: превентивну, охоронну. Цей інститут дозволяє забезпечувати на певному етапі розвитку інформаційного суспільства дотримання більше половини вимог у сфері забезпечення інформаційної безпеки на національному рівні.

Проблематика інформаційної безпеки набуває в умовах розвитку інформаційного суспільства всеосяжний, міжгалузевий характер і тому питання, пов'язані з правовим забезпеченням інформаційної безпеки і юридичною відповідальністю в інформаційній сфері, привертають увагу фахівців різних галузей науки. Важливе теоретико-правове значення для розвитку інституту юридичної відповідальності в галузі забезпечення інформаційної безпеки має оптимізація системи принципів. Для правового регулювання відносин, пов'язаних з юридичною відповідальністю, важлива уніфікація загальновизнаних, загальноправових і закріплених в окремих законодавчих актах галузевих принципів регулювання інфосфері, інформаційно-комунікаційних технологій та захисту інформації.

У контексті Закону України «Про національну безпеку України», який констатує важливість збереження принципу територіальної цілісності та державного суверенітету, доцільно виділити такі важливі принципи, необхідні для подальшого розвитку інформаційного суспільства та забезпечення інформаційної безпеки, як довіра та безпека у використанні інформаційно-комунікаційних 
технологій, що випливають 3 необхідності заохочувати, формувати, розвивати і активно впроваджувати стійку культуру кібербезпеки у контексті європейської інтеграції України на підставі реалізації Угоди про асоціацію між Україною, з одного боку, та Європейським Союзом, Свропейським співтовариством з атомної енергії і їхніми державамичленами, з іншого боку [13; 14].

У сфері безпеки об'єктів критично важливої інформаційної інфраструктури необхідно виділяти два тісно взаємопов'язаних, але різних за змістом напрями: формування та забезпечення безпечного функціонування системи; забезпечення безпеки [15, с. 2004]. 3 метою вдосконалення системи інформаційної безпеки від різних викликів і загроз пропонується закріпити в інформаційному законодавстві принцип презумпції безпеки об'єктів критичної інформаційної інфраструктури. Принцип встановлює, що об'єкти критичної інформаційної інфраструктури вважаються захищеними, поки організаційно-правове забезпечення безпеки на зазначених об'єктах відповідає вимогам, закріпленим у нормативно-правових актах у сфері забезпечення інформаційної безпеки.

Застосування цього принципу дозволить обгрунтовано кваліфікувати правопорушення з метою підвищення ефективності правозастосовної практики у сфері забезпечення інформаційної безпеки.

\section{Висновки}

Підсумовуючи викладене вище, можемо констатувати, що процеси інформатизації та цифровізації, які активно відбуваються в Україні, стосуються всіх сфер життя, включаючи економіку, соціальну сферу, охорону здоров'я і освіту, спрямовані на розвиток інформаційного суспільства, але тягнуть нові ризики, виклики та загрози для інформаційної безпеки в інформаційному просторі та цифровому середовищі. Забезпечення сталого розвитку України, безпеки інформаційного простору можливо лише за умови об'єднання зусиль усіх держав-членів Свропейського Союзу та НАТО у створенні нових правових інструментів і механізмів для розвитку ефективної системи міжнародної та інформаційної безпеки, вдосконалення наці- онального законодавства, зміцнення міжнародного співробітництва на основі розвитку базових принципів інформаційної безпеки.

\section{Аітература}

1. Зайчук О. В. Принципи права в контексті розвитку загальної теорії держави і права. URL: http://dspace.nbuv.gov.ua/bitstream/ handle/ 123456789/63854/04-Zaychuk.pdf? sequence $=1$

2. Перун Т. С. Адміністративно-правовий механізм забезпечення інформаційної безпеки в Україні: дис. ... канд.. юрид. наук: спец.: 12.00.07. Аьвів, 2019. 268 с.

3. Загальна декларація прав людини. Законодавство України. URL: https://zakon. rada.gov.ua/laws/show/995_015

4. Міжнародний пакт про громадянські та політичні права. Законодавство України. URL: https://zakon.rada.gov.ua/laws/ show $/ 995043$

5. Юридична відповідальність за правопорушення в інформаційній сфері та основи інформаційної деліктології: монограбія.I. В. Арістова, О. А. Баранов, О. П. Дзьобань та ін. Київ: КВІЦ, 2019. 344 с.

6. Ткачук Т. Ю. Правове забезпечення інформаційної безпеки в умовах євроінтеграції України: дис. … д-ра юрид. наук: спец.: 12.00.07. Ужгород, 2019. 487 с.

7. Резолюция, принятая Генеральной Ассамблеей 5 декабря 2018 года [по докладу Первого комитета (А/73/505)] 73/27. Достижения в сфере информатизации и телекоммуникаций в контексте международной безопасности. URL: https://undocs.org/ pdf?symbol $=\mathrm{ru} / \mathrm{A} / \mathrm{RES} / 73 / 27$

8. Про Цілі сталого розвитку Україні на період до 2030 року: Указ Президента України від 30.09.2019 р. № 722/2019. URL: https:// zakon.rada.gov.ua/laws/show/722/2019

9. Про основні засади забезпечення кібербезпеки України: Закон України від 05.10.2017 р. № 2163-VIII. Відомості Верховної Ради Украӥни. 2017. № 45. Ст. 403.

10. Декларації тисячоліття Організації Об'єднаних Націй. Законодавство України. URL: https://zakon.rada.gov.ua/laws/ show $/ 995 \_621$

11. Про схвалення Концепції розвитку цифрової економіки та суспільства України 


\section{Адміністративне право}

у статті досліджуються приничии юридичної відповідальності за правопорушення у сфері забезпечення інформачійної безпеки через філософбський та спеціально-юридичний аспекти. Аналіз науковоӥ літератури дозволяе виділити декілька підходів до розуміння юридичної відповідальності у сфері забезпечення інбормаційної безпеки, які втілюють особистісний та державно-владний підходи, шо зумовлено загальноправовими, міжгалузевими та галузевими принципами. Категорія приниипи у сбері забезпечення інбормачійної безпеки дозволяе найбільш точно передати правову природу юридичної відповідальності, у зв'язку з чим увага приділена притаманним рисам, співвідношенням із визначенням «інбормаційні права» через категорію «інформачійна безпека». Виділені універсальні ознаки принципів, які втілюють правову природу юридичної відповідальності незалежно від підходу до визначення.

Ключові слова: юридична відповідальність, інбормаиійна безпека, приниипи, правопорушення, кібербезпека, інформаційна інфбраструктура.

на 2018-2020 роки та затвердження плану заходів щодо ії реалізації: Постанова Кабінету Міністрів України від 17.01.2018 р. № 67-р. URL: https://zakon.rada.gov.ua/laws/show/67$\underline{\text { 2018-\%D } 1 \% 80}$

12. Бортник Н., Есімов С. Відносини в мережі Інтернет як об'єкт правового регумювання. Вісник Національного університеmу «Аввівсъка політехніка». Юридичні науки. 2019. Вип. 6. № 22. С. 147-153.

13. Про національну безпеку України: Закон України від 21.06.2018 р. № 2469-VIII. Відомості Верховної Ради України. 2018. № 31. C.т. 241.

14. Про ратифікацію Угоди про асоціацію між Україною, з однієї сторони, та Европейським Союзом, Європейським співтовариством 3 атомної енергії і їхніми державамичленами, з іншої сторони: Закон України від 16.09.2014 р. № 1678-VII. Відомості Верховної Ради Украӥни. 2014. № 40. Ст. 2021.

15. Есімов С., Ковалів М., Скриньковський Р. Правові аспекти формування сис-

\section{SUMMARY}

The article explores the principles of legal responsibility for offenses in the field of information security through philosophical and special legal aspects. The analysis of the scientific literature allows us to identify several approaches to understanding legal responsibility in the field of information security, which embody personal and state-governmental approaches, which are conditioned by generally legal, inter-sectoral and sectoral principles., in connection with which attention is paid to the inherent features, correlation with the definition of «information rights» through the category of in "organizational safety". There are universal features of principles that embody the legal nature of legal liability, regardless of approach to definition.

One of the important components of the information security system is the institution of legal responsibility. It performs a number of functions in this system: preventive, protective. This institute allows to ensure at a certain stage of development of the information society compliance with more than half of the requirements in the field of information security at the national level.

It is noted that the issue of information security in the development of the information society becomes comprehensive, intersectoral in nature, and therefore issues related to the legal provision of information security and legal responsibility in the information field, attract the attention of experts in various fields of science. The optimization of the system of principles is of great theoretical and legal importance for the development of the institution of legal responsibility in the field of information security. For the legal regulation of relations related to legal liability, it is important to unify the generally recognized, common law and enshrined in certain legislation industry principles of regulation of the infosphere, information and communication technologies and information protection.

Key words: legal responsibility, information security, principles, offenses, cyber security, information infrastructure.

теми безпеки об'єктів критично важливої інформаційної інфраструктури. Traektoriâ Nauki $=$ Path of Science. 2018. Vol. 4. № 7. S. 20012018. 


\title{
ОСОБЕННОСТИ АДМИНИСТРАТИВНЫХ ПРАВОНАРУШЕНИЙ В СФЕРЕ МИГРАЦИИ В УКРАИНЕ
}

\author{
НОВИЧЕНКО Андрей - аспиранТ Харьковского национального университета \\ внутренних дел \\ УДК: 342.951:314.15](477) \\ DOI 10.32782/LAW.2020.3.9
}

В статье рассматриваются вопросъ административной ответственности за нарушения в сбере миграционного права. Проанализирован состав административных правонарушений, за нарушения законодательства в сбере миграции в Украине. Правонарушения разделенъ на две группь предполагающие административную ответственность для самих трудовъгх мигрантов и предполагающие административную ответственность для их работодателей и принимающих лии. Исследовано место административных правонарушений в сбере миграционного права. Также раскрываться само понятие «административное правонарушение» и субъект административного правонарушения. Рассмотрено видв запретов в иммиграчии по законодательству Украинъ .

Ключевые слова: миграчия, правонарушение, иммиграчия, разрешение, иностранеи, гражданин, административное право.

Постановка проблемы

Выделение особенностей административных правонарушений в Украине, как одного из способ противодействия нелегальной миграции, способствующих внедрению действенных мер по борьбе с преступностью, связанной с нелегальной миграцией.

\section{Анализ последних исследований}

Изучение этого вопроса занимались такие украинские ученые Ю. Бузицький, А. Бабенко, С. Бритченко, А. Войцеховский, Ко- валенко, В.Кривенко, О.Кузьменко, В.Куц, О. Джужа, Ю. Кравченко, А. Малиновская, А. Надён, А. Черняк, С. Чехович, А. Пискун, И. Прибыткова, Ю. Рымаренко, В. Трощинский, В. Шакуни и др., так и зарубежные ученые Дж. Солт, М. Вийерс, Р. Хавсман, Р. Вольвенд, В. Аунеев, П. Холмс, М. Пугло, А. Шлоенхард и др.

\section{Цель статьи}

Выделить и проанализировать особенности административних правонарушений в сфере нелегальной (незаконной) миграции в Украине.

Изхожений основного материала

Административное правонарушение в миграционном праве - это действие, поведение или бездействие человека, это акт внешнего проявления отношения человека к реальности, другим людям, государству и обществу. Такое деяние следует признать административным правонарушением, если существуют определенные признаки, которые традиционно приписываются общественному ущербу, противоправности, вине и административному наказанию. Общественный вред действий в сфере регулирования миграционных процессов в Украине означает, что действие или бездействие причиняет или угрожает причинить определенный вред (материальный, моральный, организационный или иной) миграционным общественным отношениям. Неправомерное поведение означает, что действие 


\section{Адміністративне право}

или бездействие в законодательстве прямо называется правонарушением.

Действия, признанные административными правонарушениями в области регулирования миграции, перечислены в главе 14 специальной части раздела II Кодекса Украины об административных правонарушениях и в некоторых других нормативных актах. В случае установления административной ответственности за новые действия или отмены ранее существовавшей ответственности необходимо вносить изменения в Кодекс Украины об административных правонарушениях [1] и другие законы Украины.

Место, время, ситуация, метод, инструменты и средства совершения проступка могут быть незаменимыми, если они включены в конкретный состав признаков проступка (например, часть 3 статьи 206-1 Кодекса Украины об административных правонарушениях - перевозка иностранцев и лиц без гражданства в оборудованных владельцами транспортных средствах или специальных скрытых местах для перевозки людей - указывает конкретный способ совершения правонарушения или использования определенных средств). Статья 2041 Кодекса Украины об административных правонарушениях предусматривает административную ответственность за незавершенные действия (попытки пересечь государственную границу Украины любым способом за пределами пунктов пересечения границы Украины), но нет общего правила относительно этапов административного преступления, которое полностью оправдано. Субъективная сторона административного правонарушения связана с совершением психической деятельности человека. Характеристики включают вину, мотив и цель преступления.

Преступление было совершено по небрежности, когда человек предвидел возможность вредных последствий своего действия или бездействия, но ложно рассчитывал на их предотвращение или не предвидел возможности таких последствий, хотя он должен был и мог их предвидеть (потеря паспорта) - статья 198.

Субъект административного правонарушения определяется применимым Ко- дексом об административных правонарушениях как здравомыслящий человек, достигший (к моменту совершения проступка) возраста, с которого начинается административная ответственность. В дополнение к этим общим признакам в конкретных составах субъект также может характеризоваться дополнительными специфическими свойствами. Такие объекты называются специальными объектами. К ним относятся, например, должностные лица (статья 204); лица, ответственные за соблюдение правил паспортной системы (статья 199); владельцы или водители транспортных средств(ст. 206-1); капитаны иностранных судов(ст. 207) и т. д. Все признаки административного проступка взаимосвязаны и взаимозависимы, что делает его полным системным образованием.

Согласно Закону Украины «Об иммиграции» [2], иммиграция - это прибытие в Украину или выезд в Украину иностранцев и лиц без гражданства на постоянное место жительства в законном порядке. Иммигрант - это иностранец или лицо без гражданства, которые получили разрешение на иммиграцию и прибыли в Украину на постоянное жительство, или, находясь в Украине на законных основаниях, получили разрешение на иммиграцию и остались в Украине на постоянное место жительства.

Что касается запрета иммиграции по законодательству Украины: вопросы иммиграции регулируются Конституцией Украины, Законом Украины «Об иммиграции» и другими нормативными правовыми актами, которые не должны им противоречить. Если международным договором Украины, согласие на который предоставлено Верховной Радой Украины, установлены правила, отличные от тех, которые содержатся в упомянутом законе, то применяются правила международного договора Украины.

Государственная миграционная служба Украины имеет основные задачи: реализация государственной политики в сфере миграции (иммиграция и эмиграция), в том числе борьба с нелегальной миграцией, гражданство, регистрация физических лиц, беженцев и других категорий мигрантов, определенных законом; внесение министру 
внутренних дел предложений по обеспечению формирования государственной политики в сфере миграции (иммиграции и эмиграции), в том числе борьбы с нелегальной миграцией, гражданства, регистрации физических лиц, беженцев и других категорий мигрантов, определенных законом. Одна из основных функций: ГМС проводит анализ миграционной ситуации в Украине, проблем беженцев и других категорий мигрантов, разрабатывает текущие и долгосрочные прогнозы по этим вопросам; готовит предложения по определению иммиграционной квоты на календарный год; принимает решение о выдаче разрешения на иммиграцию, об отказе в его выдаче и отзыве такого разрешения. [3, 4]

В соответствии со статьей 4 Закона Украины «Об иммиграции» разрешение на иммиграцию выдается в пределах иммиграционной квоты. Квота иммиграции устанавливается Кабинетом Министров Украины. Иммиграция вне квоты предоставляется:

- одному из супругов, если другой (с которым человек состоит в браке более двух лет) является гражданином Украины, детям и родителям граждан Украины;

- лица, которые являются опекунами или содержателями граждан Украины или находятся под опекой граждан Украины;

- лица, которые имеют право на получение гражданства Украины по территориальному происхождению;

- лица, иммиграция которых представляет национальный интерес для Украины.

Закон запрещает иммиграционные разрешения:

- лицам, приговоренным к лишению свободы на срок более одного года за совершение деяния, которое в соответствии с законодательством Украины признается преступлением, если судимость не погашена или не снята;

- лицам, которые совершили преступление против мира, военное преступление или преступление против человечности, как они определены в международном праве, или разыскиваются в связи с совершением деяния, признанного в соответствии с законодательством Украины серьезным преступлением, или против которых возбуждено уголовное дело, если предварительное следствие не завершено;

- лицам, страдающим хроническим алкоголизмом, токсикоманией, наркоманией или инфекционными заболеваниями, перечень которых определен центральным органом здравоохранения;

- лицам, которые в своих заявлениях на получение разрешения на иммиграцию предоставили заведомо ложную информацию или представили поддельные документы;

- лицам, которым запрещен въезд на территорию Украины по закону;

- в других случаях, предусмотренных законами Украины.

Вина является основной и обязательной чертой субъективной стороны любого административного проступка. Именно психическое отношение человека к социально вредному деянию и его последствиям проявляется в форме умысла или небрежности. Концепция раскрыта в статьях 10 и 11 Кодекса Украины об административных правонарушениях. Административное правонарушение признается преднамеренным, когда лицо, которое совершило его, осознавало незаконный характер его действия или бездействия, предвидело его вредные последствия и хотело их или сознательно допускало возникновение этих последствий (например, преднамеренное повреждение паспорта - статья 198; несоблюдение правил паспортной системы, проживание граждан без паспортов - статья 199; нарушение порядка предоставления иностранцам и лицам без гражданства жилья, транспортных средств и помощи в предоставлении других услуг - статья 199; оборудование собственниками или водителями транспортных средств специально скрытых или скрытых мест, используемых для перевозки нелегальных мигрантов - часть 2 статьи 206-1 Кодекса об административных правонарушениях и т. д.).

Аицу, постоянно проживающему за пределами Украины, которое, наконец, получило разрешение на иммиграцию, дипломатическим представительством или консульским учреждением Украины выдается иммиграционная виза по его / её запросу. 


\section{Адміністративне право}

y статті розглядаються питання адміністративної відповідальності за порушення в сффері міграчійного права. Проаналізовано склад адміністративних правопорушень, за порушення законодавства у сфері міграиї в Україні. Правопорушення розділені на дві групи передбачають адміністративну відповідальність для самих трудових мігрантів $i$ передбачають адміністративну відповідальність для їх роботодавијв $і$ приймають осіб. Досліджено місце адміністративних правопорушень в сбері міграчійного права. Також розкриватися саме поняття «адміністративне правопорушення» $і$ суб'єкт адміністративного правопорушення. Розглянуто види заборон в імміграчї̈ за законодавством України.

Ключові слова: міграчія, правопорушення, імміграчія, дозвіл, іноземець, громадянин, адміністративне право.

Закон предусматривает следующие основания для отзыва разрешения на иммиграцию:

- в случае, если выясняется, что разрешение было предоставлено на основании заведомо ложных сведений, поддельных документов или утраченных документов;

- иммигрант был приговорен к лишению свободы в Украине на срок более одного года, и приговор суда вступил в законную силу;

- действия иммигранта представляют угрозу национальной безопасности Украины, общественному порядку в Украине;

- это необходимо для защиты здоровья, прав и законных интересов граждан Украины;

- иммигрант нарушил закон о правовом статусе иностранцев и лиц без гражданства;

- в других случаях, предусмотренных законами Украины.

Аицо может повторно подать заявление на получение разрешения на иммиграцию не позднее, чем через год после принятия решения об отказе или отмене разрешения на иммиграцию.

\section{SUMMARY}

The article deals with the issues of administrative responsibility for violations in the field of migration law. The composition of administrative offenses for violations of legislation in the field of migration in Ukraine is analyzed. Offenses are divided into two groups, implying administrative responsibility for the labor migrants themselves and assuming administrative responsibility for their employers and recipients. The place of administrative offenses in the field of migration law has been investigated. Also, the very concept of "administrative offense" and the subject of an administrative offense should be revealed. The types of prohibitions in immigration under the legislation of Ukraine are considered.

Key words: migration, offense, immigration, permission, foreigner, citizen, administrative law.

Что касается статистики, то за 9 месяцев 2019 года Государственная миграционная служба наложила 45415186 штрафов на нарушителей миграционного законодательства. В разрешении на иммиграцию было отказано 202 раза. 1889 разрешений на иммиграцию были отменены [5].

\section{Аитература}

1) Кодекс Украины об административных правонарушениях. Режим электронного доступа: https://zakon.rada.gov.ua/laws/ show/80731-10

2) Закон Украины «Об иммиграции». Режим электронного доступа: https://zakon. rada.gov.ua/laws/show/2491-14

3) Сайт Государственной миграционной службы Украины. Историческая справка. Режим электронного доступа: https://dmsu. gov.ua/pro-dms/zagalna-informacziya.html

4) Постановление Кабинета Министров Украины от 20 августа 2014 года № 360. Положение о Государственной миграционной службе Украины. Режим электронного доступа: http://zakon5.rada.gov.ua/laws/ show/360-2014-\%D0\%BF

5) Статистика Государственной миграционной службы (2019). Официальный сайт ГМС. Режим электронного доступа: https:// dmsu.gov.ua/assets/files/statistic/year/2019_9.pdf 


\title{
МОБІЛЬНІ РЕСУРСИ АДМІНІСТРАТИВНИХ ПОСЛУГ B УKPAÏ̈I
}

\author{
СМАЗНА Тетяна Миколаївна - аспірант кафедри адміністративного права \\ ХНУВС
}

DOI 10.32782/LAW.2020.3.10

Постановка проблеми

Суб’єкти адміністративного права реалізують свої повноваження із застосуванням електронних технологій за допомогою визначеної системи дій, яка становить окремий вид публічної діяльності. Якщо йдеться про зовнішньоуправлінські повноваження, то найбільш поширеним видом такої діяльності $є$ надання адміністративних послуг через онлайн-сервіси.

Аналіз останніх досліджень і публікацій $з$ даної теми

Окремі аспекти проблеми надання електронних послуг досліджували такі вчені, як В.В. Сжунінов, П.С. Клімушин, С.I. Куценко, Р.М. Матвійчук, А.О. Серенок, та ін.

Теоретичні аспекти надання адміністративних послуг розглядали дослідники: В. Авер'янов, О. Бандурка, Ю. Битяк, ^. Біла, Н. Бортник, Т. Гуржій, Є. Додін, Р. Калюжний, Т. Коломоєць, В. Колпаков, О. Кузьменко, Є. Курінний, В. Ортинський, О. Остапенко, С. Пєтков, М. Тищенко, В. Шамрай та ін. Водночас, впровадження інформаційно-комунікаційних технологій вимагає дослідження нормативно-правових засобів регулювання цього процесу у сфері надання адміністративних послуг в електронному вигляді.

Актуальних досліджень, присвячених визначенню поняття та умов запровадження електронних послуг в Україні, останнім часом не було.
Метою даного дослідження $є$ визначення поняття та умов запровадження електронних адміністративних послуг в Україні. Для виконання поставленої мети необхідно виконати такі завдання: визначити поняття та охарактеризувати правову природу надання адміністративних послуг через онлайн-сервіси; виявити основні переваги електронних послуг; дослідити сучасний стан та визначити умови впровадження електронних послуг в Україні.

\section{Виклад основного матеріалу}

Державні служби у відповідь на очікування громадян в отриманні якісних та оперативних послуг прагнуть удосконалити свою діяльність, використовуючи нові технології та різні рішення, які спрощують управління взаємовідносинами та доступ до інформації. Це зумовлено прийняттям низки документів, які сприяють цьому процесу, зокрема, -це Стратегії сталого розвитку “Україна - 2020"”, національної безпеки України, кібербезпеки України, розвитку інформаційного суспільства в Україні. Крім того, інформатизація стає важливою складовою оптимізації процесів усередині самих державних структур, відіграючи особливу роль в проведені адміністративні реформи, реформуванні системи освіти, пенсійної та іншими реформами. Застосування інформаційно-комунікаційних технологій передбачає створення електронного урядування відповідно до Концепції розвитку електронного урядування в Україні ${ }^{2}$ Стратегічною 


\section{Адміністративне право}

метою електронного урядування є зміна взаємовідносин влади з суспільством, удосконалення сфери надання послуг населенню та бізнесу, розширення ступеня участі всіх громадян у процесах управління суспільством i державою. Електронне урядування як ефективний інструмент державного управління вирішує численні проблеми інформаційної взаємодії, сприяє усуненню бюрократичного бар'єру між державною службою і людиною, покращуючи доступ до державних інформаційних ресурсів, спрощуючи отримання необхідної інформації та послуг.

У моделі сервісно-орієнтованої держави надання державою послуг є найважливішою функцією державних структур. Поняття «послуги» виражає певну категорію, яка вказує на взаємодію між суб'єктом, що пропонує i надає послуги об’єкту, який їх потребує. Під будь-якою послугою розуміється діяльність, спрямована на задоволення певних потреб людини, тобто послуга - це дія, результат якої споживається в процесі ії̈ надання.

Вперше у законодавстві України термін «електронна послуга» визначено у Стратегії розвитку інформаційного суспільства в Україні у значенні «послуга, надана громадянам та організаціям в електронному вигляді за допомогою інформаційно-комунікаційних технологій».

Електронна адміністративна послуга - адміністративна послуга, що надається суб'єкту звернення в електронній формі за допомогою інформаційно-комунікаційних технологій. Можливим визначенням поняття «електронна послуга» $є$ ще й таке: електронна послуга - це послуга із задоволення інформаційних потреб користувача, яка має електронну форму надання. До електронних послуг належать:

усі електронні адміністративні послуги; онлайн оплата за комунальні послуги, інтернет, телефонію; інтернет-банкінг, інтернетстрахування; купівля через інтернет квитків на потяги, літаки, автобуси; купівля товарів в інтернет-магазинах; онлайн запис у дитячий садок; електронна черга, наприклад, у ЦНАП як в онлайн реалізації (через інтернет), так і в оффлайн (шляхом особистого приходу та фізичного отримання квитка через інформаційний термінал) тощо.
За даними опитування громадської думки $33 \%$ громадян користувалися електронними послугами, які надає бізнес. Разом 3 тим 56\% населення. ніколи не користувалися електронними адміністративними послугами.

Важливим принципом надання електронних адміністративних послуг є їх доступність 24 години на добу та 7 днів на тиждень.

При запровадженні електронних адміністративних послуг для їх користувачів мають бути доступними такі сервіси:

- зручний доступ до актуальної інформації про послугу через відповідний портал або веб-сайт;

Також при цьому широко практикується sms-інформування;

- онлайн оплата за надання адміністративної послуги, якщо така плата встановлена.

У рамках реалізації Угоди про асоціацію з Европейським Союзом ${ }^{3}$ Україна має забезпечити комплексний розвиток електронних послуг відповідно до європейських вимог. Разом $з$ тим, згідно з результатами передостаннього дослідження ООН (United Nations E-government Survey 2014) ${ }^{4}$ щодо розвитку електронного урядування (E-Government Development Index) Україна посіла 87 місце серед 193 країн, втративши 19 позицій за останні 2 роки та 33 позиції за останні чотири роки. При цьому, найбільш низьку оцінку - 0,2677 Україна отримала за компонентом «Онлайн послуги», яка удвічі нижча відповідного показника 2012 року $(0,4248)$, тобто регрес є відчутним.

Статтею 17 Закону України «Про адміністративні послуги» ${ }^{5}$ визначено, що адміністративні послуги в електронній формі надаються через Сдиний державний портал адміністративних послуг (www.poslugy. gov.ua), у тому числі через інтегровані з ним інформаційні системи державних органів та органів місцевого самоврядування. Портал ведеться з метою забезпечення доступу суб'єктів звернення до інформації про адміністративні послуги з використанням Інтернету і є офіційним джерелом інформації про надання адміністративних послуг.

На цей час у світовій практиці для надання публічних послуг використовуються пе- 
реважно такі канали або їх комбінації: особистий прийом громадян; телефонний (голосовий) сервіс та call-центри; веб-портал; електронна пошта; SMS і інші сервісі обміну повідомленнями; мобільний портал (мобільний сайт); мобільний додаток; соціальні мережі; посередники на основі державно-приватного партнерства.

На цей час портали публічних послуг створені практично у всіх країнах світу. Основними каналами надання публічних послуг стають веб-портал і мобільний канал, що включає використання мобільного порталу і мобільних додатків. Для надання електронних публічних послуг необхідно пройти, як мінімум, три етапи формування електронного уряду за методологією ООН.

Зарубіжний досвід, зокрема Естонії, свідчить, що успішному запровадженню електронних послуг сприяють:

- політична воля перших осіб держави;

- належна законодавча підтримка;

- упровадження ефективних та зручних для населення засобів електронної ідентифікації;

- забезпечення захисту інформації у процесі надання електронних послуг; - ефективна взаємодія держави та IT-бізнесу у процесі реалізації організаційних, технологічних і технічних рішень, електронних послуг.

32015 року в Україні розпочато впровадження окремих електронних адміністративних послуг, якими уже досить активно користуються українці. При наданні електронних адміністративних послуг міністерствами та іншими центральними органами виконавчої влади України в усіх випадках для електронної ідентифікації застосовуються електронні цифрові підписи, а в окремих - i BankID. У липні 2015 року перші електронні послуги були запроваджені через веб-сайт «Державна архітектурно-будівельна інспекція України. Електронні адміністративні послуги» (e-dabi.gov.ua).

Через Інтернет-ресурси Держгеокадастру, Міністерства Юстиції України, Мiністерства екології та природних ресурсів України, Міністерства економічного розвитку, Державної-архітекторної -будівельної інспекції, Державної фіскальної служби,
Пенсійного фонду України, окремих місцевих ЦНАПів уже надаються електронні адміністративні послуги або доступне їх замовлення в електронному форматі. При наданні електронних адміністративних послуг міністерствами та іншими центральними органами виконавчої влади України в усіх випадках для електронної ідентифікації застосовуються електронні цифрові підписи, а в окремих - i BankID. До важливих проблем надання електронних адміністративних послуг в Україні належать:

- невпровадження у промислову експлуатацію Єдиного державного порталу адміністративних послуг;

- відсутність законодавчих підстав таких видів електронної ідентифікації користувачів при отриманні ними електронних адміністративних послуг, як BankID, MobileID;

- невпровадження системи електронної взаємодії державних інформаційних ресурсів, державних реєстрів, систем електронного документообігу різних органів державної влади та органів місцевого самоврядування.

Наразі потенціал «мобільного уряду» в Україні використовується недостатньо. Згідно з результатами громадського моніторингу впровадження до діяльності органів місцевого самоврядування України технологій електронного урядування, на сьогодні мобільна версія веб-сайту наявна лише на $3 \%$ веб-сайтів органів місцевого самоврядування. Рідко використовується при наданні адміністративних послуг і такий інструмент «мобільного уряду», як СМС повідомлення.

\section{Висновки}

Використання таких технологій «мобільного уряду», як СМС повідомлення, мобільні портали, мобільні додатки у сфері надання адміністративних послуг, зокрема, дозволяє надавати громадянам інформацію про адміністративні послуги, отримувати зворотній зв'язок від споживачів послуг (наприклад, щодо якості обслуговування), надає споживачам адміністративних послуг можливість замовити необхідну послугу, записатись на прийом, отримати бланки заяв для оформлення адміністративної послуги, 


\section{Адміністративне право}

у статті розглянуто нормативно-правове регулювання, що впливає на розвиток системи надання електронних адміністративних послуг в Україні в контексті досвіду електронного урядування в краӥнах-членах Европейсъкого Союзу. На підставі аналізу законодавства Украйни, інших нормативно-правових актів розкриваються сутність надання адміністративної послуги в електронному виді, електронної взаємодї̈ органів влади, визначаються проблеми, шоо виникають унаслідок застосування інбормачійнокомунікачійних технологій. В статті розглянуті Інтернет-ресурси Держгеокадастру, Міністерства Юстииї Украӥни, Міністерства екологї та природних ресурсів України, Міністерства економічного розвитку, Державної-архітекторної -будівельної інспекиї, Державної фіскальной служби, Пенсійного бонду Украӥни, окремих місцевих Центрах Надання Адміністративних Послуг в яких надаються електронні адміністративні послуги або доступне їх замовлення в електронному борматі. Проведені опитування громадсъкої думки, на тему питання введень електронних послуг. Розглянуто досвід інших країн, та які переваги використання електронних послуг має Украӥна.

Ключові слова: держава, послуги, адміністративні послуги, електронні послуги

а також інформацію про хід розгляду їхніх заяв.

Перевагами використання мобільного зв'язку як додаткового каналу надання електронних адміністративних послуг $\epsilon$ широке охоплення аудиторії, можливість надання послуг у будь-який час, незалежно від місцезнаходження споживача послуги, а також простий, зручний та зрозумілий для споживача спосіб надання послуги.

Окрім цього, використання інструментів «мобільного уряду» сприяе популяризації електронних адміністративних послуг, стимулює використання населенням нових видів електронних сервісів.
The article considers the legal regulation that affects the development of the system of electronic administrative services in Ukraine in the context of the experience of e-government in the member states of the European Union. On the basis of the analysis of the legislation of Ukraine, other normative-legal acts the essence of rendering of administrative service in an electronic kind, electronic interaction of authorities is revealed, the problems arising owing to application of information and communication technologies are defined. The article examines the Internet resources of the State Geocadastre, the Ministry of Justice of Ukraine, the Ministry of Ecology and Natural Resources of Ukraine, the Ministry of Economic Development, the State Architectural and Construction Inspectorate, the State Fiscal Service, the Pension Fund of Ukraine, and some local CNAPS. in electronic format. Public opinion polls were conducted on the introduction of electronic services. The experience of other countries and the advantages of using electronic services in Ukraine are considered.

Key words: state, services, administrative services, electronic services

\section{Лiтература}

1. Стратегії сталого розвитку "Україна - 2020 [Електронний ресурс]. - Режим доступу: https://zakon.rada.gov.ua/laws/ show/5/2015\#Text

2. Концепції розвитку електронного урядування в Україні [Електронний ресурс]. - Режим доступу: https://www.kmu.gov.ua/ npas/250287124

3. Угоди про асоціацію з Европейським Союзом [Електронний ресурс]. - Режим доступу: https://www.kmu.gov.ua/diyalnist/ yevropejska-integraciya/ugoda-pro-asociacyu

4. OOH (United Nations E-government Survey 2014) [Електронний ресурс]. - Режим доступу: https://www.un.org/en/development/ desa/publications/e-government-survey-2014. $\underline{\mathrm{html}}$

5. Закон України «Про адміністративні послуги» [Електронний ресурс]. - Peжим доступу: http://zakon2.rada.gov.ua/laws/ show/5203-17 


\title{
МЕХАНІЗМИ ЗАБЕЗПЕЧЕННЯ ПРАВ ДІТЕЙ В ІНФОРМАЦІЙНОМУ СЕРЕДОВИЩІ
}

\author{
НЕСТЕРЕНКО Анна Олександрівна - аспірант кафедри адміністративного \\ та інформаційного права, Навчально-науковий Інститут права, психології та \\ інноваційної освіти Національного університету «Львівська політехніка» \\ УДК 340.342.7.053.6(043.5) \\ DOI 10.32782/LAW.2020.3.11
}

Статья посвящена исследованию механизма обеспечения прав детей в инбормачионной среде. Отмечено, что под механизмом защиты прав и свобод человека и гражданина, необходимо понимать установленную и гарантированную законом систему обеспечения правового статуса личности, включающей упорядоченную деятельность органов публичной власти, негосударственнъгх правозащитнъгх организаций, самостоятельную реализаиию субъективньих прав и свобод, бункиионирование которых направлено на предупреждение, пресечение и восстановление нарушенных прав и свобод при соблюдении надлежащего баланса публичных и частнъхх интересов.

Ключевъе слова: права ребенка, механизм обеспечения прав ребенка, инбормачионная среда, ювенальная юстищия.

Постановка проблеми

Сучасний етап розвитку суспільства та держави найвищими цінностями проголошує права людини будь-якого віку. Історичне минуле, коли вперше питання про права людини були підняті на державному рівні, відноситься до XVIII століття. Проте, для виділення 3-поміж них прав дитини знадобилось ще два століття. Протягом тисячоліть діти розглядалися як майбутні члени суспільства. У міру становлення уявлень про самоцінність людської особистості в дітях стали бачити не тільки об'єкт виховного впливу, а й рівноправ- ного партнера суспільних відносин. Надбанням такого розуміння $\epsilon$ те, що дитина стала розглядатися як особистість, яка наділена гідністю, як дорослий з різницею в тому, що повнолітній може захищати свої інтереси самостійно, а дитина змушена звертатися за допомогою до тих, хто повинен забезпечувати її права. У цьому полягає специфіка механізму забезпечення прав дітей в інформаційному середовищі.

Аналіз дослідження проблеми

Забезпечення прав дітей, у тому числі в інформаційному середовищі досліджували вчені: А. Блага, Н. Бортник,В. Брижик, А. Волощук, В. Галунько,Б. Головкін, Т. Журавель, В. Копєйчиков,O . К о ч е ᄉ. Крижна, К. Левченко,Н. Аесько, Ю. Аисюк, О. Мартиненко, П. Рабінович, Ю. Приколотіна, Н. Ортинська, Г. Христова, Х. Ярмакі, М. Ясеновська та інші. Розвиток теоретичних уявлень про права та свободи людини, а також інформаційного суспільства ставить перед науковою спільнотою та практикуючими правознавцями питання щодо прав дитини, які підлягають аналізу.

Метою статті є дослідження механізму забезпечення прав дітей в інформаційному середовищі. 


\section{$=$ Адміністративне право}

Виклад основного матеріалу

Інформаційні права належать до молодого покоління прав людини. Вплив трансформаційних процесів соціуму вказує на важливу роль інформаційних прав для реалізації та захисту правового статусу людини.

У цьому контексті Н. Ортинська зазначає, що право на доступ до інформації має для неповнолітнього свої особливості, оскільки, враховуючи його моральну незрілість, правова політика держави повинна бути спрямована на обмеження отримання неповнолітнім інформації, яка негативно впливатиме на емоційний чи фізичний стан. Проте якщо йдеться про неповнолітню особу, інформаційні права мають особливості забезпечення та реалізації. Інформаційні права неповнолітніх є ефективною формою соціалізації у демократичному суспільстві, показником активної громадянської позиції підростаючого покоління і своєрідним показником розвитку особистості. Європейська конвенція про здійснення прав дітей визнає, що дітям для підтримки прав та найвищих інтересів має надаватися відповідна інформація та, що думкам дитини має приділятися належна увага [1, с. 170-171].

Перш ніж з'ясувати юридичну природу механізму забезпечення прав дітей в інформаційному середовищі зокрема, звернемося до аналізу механізму захисту прав людини взагалі, де цей термін у різних авторів отримав різне тлумачення.

Державно-правовий механізм охорони основних прав і свобод громадян - це система конституційно-правових норм, структура державних органів, різноманітні політико-правові, соціально-економічні та соціально-психологічні чинники, форми та методи, способи, умови, засоби здійснення правових норм щодо встановлених процедур і принципів [2, с. 1012].

Механізм захисту суб'єктивного права і законних інтересів, на нашу думку, - це взята в єдності система правових засобів, за допомогою якої забезпечується відновлення порушених суб'єктивних прав, захист охоронюваних законом інтересів, вирішення правових спорів і усунення інших перешкод в реалізації суб'єктивних прав. Механізм соціально-юридичного захисту прав людини - це певна система засобів і чинників, що забезпечують необхідні умови поваги до всіх прав і основних свобод людини, що випливають із гідності, властивої людській особистості, е суттевими для вільного та повного розвитку. Головна мета функціонування механізму - це захист суб'єктивних прав людини та громадянина.

Як зазначає Н. Опольська, підхід щодо механізму дає змогу розглянути забезпечення прав та свобод людини у двох вимірах: статичному та динамічному. Досліджуючи це поняття як статичне явище, можна охарактеризувати його структуру, сукупність складових елементів [3, с. 194].

До завдань механізму входить охорона, захист, відновлення порушених прав, формування загальної та правової культури населення. Однак, аналізована юридична категорія потребує узагальнення i уточнення. На нашу думку, під механізмом захисту прав і свобод людини та громадянина необхідно розуміти встановлену та гарантовану законом систему забезпечення правового статусу особи, що включає впорядковану діяльність органів публічної влади, недержавних правозахисних організацій, самостійну реалізацію суб'єктивних прав і свобод, функціонування яких спрямоване на попередження, припинення та відновлення порушених прав і свобод при дотриманні належного балансу публічних і приватних інтересів.

Що стосується механізму забезпечення прав дітей в інформаційному середовищі, то в цьому випадку, з погляду на дослідження Н. Лесько, «адміністративно-правове забезпечення формування та реалізації державної політики у сфері захисту дітей від насильства та інших протиправних дій», - правозахисний механізм неповнолітніх - це система взаємодіючих соціальних і правових засобів, що застосовуються для забезпечення прав [4]. 
У цьому випадку автор акцентує увагу на системі засобів соціального та правового забезпечення прав дитини. Під соціальним забезпеченням слід розуміти систему економічних, організаційних, правових заходів, які гарантуються державою та забезпечують неповнолітнім громадянам умови для подолання важких життєвих ситуації. Поняття правового захисту трактується як забезпечення прав і законних інтересів юридичними засобами.

Варто зазначити, що дефініція «соціальне забезпечення» набагато ширше поняття «правове забезпечення», оскільки останнє входить у категорію першого, виходячи з того, що юридичні засоби - частина соціальної системи регулювання та впливу на суспільні відносини, в тому числі у питаннях забезпечення прав, охорони та захисту особи [5].

Спеціальний механізм забезпечення прав дітей, у тому числі в інформаційному середовищі, в Україні, включає напрями:

- заходи забезпечення прав дітей в інформаційному середовищі при здійсненні діяльності у галузі освіти та виховання, що реалізуються шляхом створення 3 ініціативи неповнолітніх громадських об'єднань (організацій) за місцем навчання; проведення дисциплінарного розслідування діяльності працівників закладів освіти, які порушують і обмежують права неповнолітніх учнів, проведення в позаурочний час зборів з питань захисту прав;

- забезпечення прав неповнолітніх на охорону здоров'я, які здійснюють через надання дітям безкоштовної медичної допомоги та медичної діагностики, проведення лікувально-оздоровчої роботи,у тому числі диспансерного спостереження, медичної реабілітації дітей-інвалідів та дітей, які страждають хронічними захворюваннями, санаторно-курортне лікування дітей, профілактичні заходи щодо позбавлення ігрової та Інтернет залежності;

- захист прав і законних інтересів неповнолітніх громадян у сфері професійної орієнтації, професійної підготовки та за- йнятості. Такий вид передбачає заходи, пов'язані із забезпеченням професійної орієнтації, професійної підготовки дітей, які досягли 14-ти річного віку. У разі прийому на роботу дітей, які досягли 15-ти річного віку, їм гарантують винагороду за працю, охорону праці, скорочений робочий день, відпустка, а працівникам молодше 18-ти років надаються пільги при поєднанні роботи з навчанням, проведення щорічного обов'язкового медичного огляду тощо;

- захист прав дітей на відпочинок i оздоровлення, що реалізується через збереження та розвиток установ, діяльність яких спрямована на відпочинок і оздоровлення дітей;

- захист прав і законних інтересів дитини при формуванні соціальної інфраструктури для дітей, у тому числі інформаційної, що здійснюється за допомогою експертної оцінки і обліку нормативів будівництва об’єктів соціальної інфраструктури для дітей, використання цих об'єктів тільки за прямим призначенням;

- захист дитини від інформації, пропаганди та агітації, що завдають шкоди здоров'ю, моральному та духовному розвитку, що реалізується шляхом вжиття заходів, у тому числі захисту від національної, соціальної нетерпимості, від реклами алкогольної продукції та тютюнових виробів, від пропаганди соціальної, расової, національної та релігійної нерівності, від поширення друкованої продукції, аудіота відеопродукції, що пропагує насильство та жорстокість, порнографію, наркоманію, токсикоманію, антигромадську поведінку [4, с. 270];

- захист прав дітей, які перебувають у важкій життєвій ситуації, яка здійснюється шляхом соціальної реабілітації, судового захисту прав, позасудових процедур 3 урахуванням забезпечення пріоритету особистого та соціального благополуччя дитини, особливостей віку та соціального стану неповнолітнього.

На думку Т. Перуна, механізм $є$ категорією теорії права, яка повинна відобража- 


\section{Адміністративне право}

ти момент «руху правової форми», спосіб iii функціонування і систему юридичних засобів впливу, які в сукупності складають правове регулювання [5, с. 90].

Конструкція механізму забезпечення прав дітей в інформаційному середовищі включає: нормативну визначеність (закріплення в нормативно-правовому акті); органи (систему органів) публічної влади, наділені функціями забезпечення прав дітей в інформаційному середовищі; систему показників, звітності та централізованого збору інформації, що відображає стан практики адміністративно-правового забезпечення прав дітей в інформаційному середовищі; спеціальні заходи адміністративно-правового забезпечення прав дітей в інформаційному середовищі; наявність норм, що передбачають юридичну відповідальність за посягання на охоронювані відносини; інші заходи забезпечення прав дітей в інформаційному середовищі, пов'язані з соціальною адаптацією; спрямовані на інформування про негативні наслідки (правові, медичні, соціальні тощо), антисоціальні явища; спрямовані на зміцнення та захист інституту сім'ї; заборона пропаганди та реклами антисоціальних явищ; взаємодія органів виконавчої влади 3 громадськістю (в тому числі волонтерськими організаціями); спеціалізовану соціальну допомогу; психологічне забезпечення прав дітей в інформаційному середовищі; духовне (релігійне) забезпечення прав дітей в інформаційному середовищі.

Стосовно об'єктів забезпечення вчені виділяють різні ознаки. Об'єкт забезпечення повинен володіти такими ознаками: реально існувати незалежно від волі та свідомості громадян, становити для особи, суспільства та держави певну цінність, благо; відчувати потребу в охороні, бути захищеним від протиправних та інших дій, погроз будь-якого характеру; на нього поширюється суверенітет держави, його забезпечення $\epsilon$ внутрішньою справою держави; він повинен знаходитися у взаємодії з суб'єктом забезпечення і охорони, який встановлює правовий режим; повинен передбачатися нормами права; забезпечення права повинно носити предметний характер [6, с. 247-248].

Забезпечення прав дітей в інформаційному середовищі як об'єкт має на увазі наявність соціальних благ, визнаних державою та захищених органами публічної влади, за посягання на які передбачається можливість застосування заходів державного захисту. Характеризуючи елементи конструкції адміністративно-правового забезпечення прав дітей в інформаційному середовищі, необхідно підкреслити, що одним 3 них 6 нормативна визначеність. Базові, вихідні положення закріплюються в основних законах держав, що дозволяє спочатку вважати права дітей в інформаційному середовищі об'єктом конституційно-правового захисту.

У конституціях, передусім, знаходять відображення відносини, пов'язані з правами громадян, їх забезпеченням. Відносини встановлені на конституційному рівні орієнтовані на морально-етичні установки суспільства і одночасно визначають вектор його розвитку. Можна запропонувати таку градацію груп норм, що регламентують забезпечення прав дітей в інформаційному середовищі, відповідно цільової спрямованості та функціям.

Групи норм, у яких права дітей системно вказується як мета забезпечення поряд 3 іншими базовими для держави об'єктами захисту, такими як основи конституційного ладу, здоров'я, права та законні інтереси інших осіб, забезпечення оборони країни та безпеки держави.

Групи норм, у яких права дітей закріплюються як єдиний родовий об'єкт посягання при вчиненні злочинів і адміністративних правопорушень. Конкретні різновиди посягань виражають об'єктивну сторону правопорушень, відповідні суспільні відносини охороняють санкції.

Групи норм, спрямовані на захист моральності неповнолітніх. Відповідно до Закону України «Про охорону дитинства» до повноважень органів державної влади України на здійснення гарантій прав 
дитини відноситься вибір пріоритетних напрямів діяльності щодо забезпечення прав і законних інтересів дитини, охорони здоров'я та моральності визначеної Законом України «Про захист суспільної моралі» $[7 ; 8]$.

У вказаних законах сформульовано поняття інформаційної безпеки дітей; конкретизовані види інформації, що завдає шкоди здоров'ю та розвитку дітей; викладено порядок класифікації інформаційної продукції; визначені державні органи та громадські об'єднання, уповноважені здійснювати нагляд і контроль за дотриманням цього законодавства; встановлені вимоги для експертів, які здійснюють проведення експертизи інформаційної продукції.

Групи норм, що передбачають обмеження в професійній діяльності у зв'язку з наявністю судимості за вчинення злочинів проти суспільної моралі. Кодекс законів про працю України містить заборону на допуск до педагогічної діяльності осіб, які мають або мали судимість або піддавалися кримінальному переслідуванню.

у реалізації розглянутого механізму забезпечення прав дітей, у тому числі в інформаційному середовищі, існує низка проблем, які заслуговують уваги в контексті нашого дослідження.

Перша проблема полягає в тому, що, незважаючи на значний масив нормативних актів, так чи інакше пов'язаних з регулюванням прав дитини, спеціалізоване законодавство, що стосується неповнолітніх, не дає повного або вичерпного переліку державних органів і установ, які здійснюють державну політику в інтересах дітей, не є можливим визначити суб'єктів, відповідальних за соціально-правове становище неповнолітніх в Україні.

Друга проблема полягає у відсутності взаємодії органів держави, покликаних забезпечувати права дитини. Хоча, в реальності, така взаємодія має відбуватися при співпраці органів управління соціальним захистом населення, органів управління освітою, органів опіки та піклування, органів у справах молоді, органів управління охороною здоров'я, органів служби зайнятості, Національної поліції, інститутами Уповноваженого Президента з прав дитини, Уповноваженого Верховної ради України з прав людини.

Однак, на жаль, доводиться констатувати, що всі ці ланки державного апарату та місцевого самоврядування нині не вдається з'єднати в один ланцюжок, розподілити між ними компетенцію за гілками та рівнями влади, виключивши одночасно дублювання та паралелізм у роботі.

Водночас, можна сформулювати й третю проблему, що створює труднощі для ефективності дії правового захисту прав дитини. Немає єдиної системи, орієнтованої тільки на вирішення проблеми захисту прав дитини. Сьогодні захист прав неповнолітніх громадян в Україні реалізується різними суб'єктами в різних формах, на різних щаблях і рівнях захисту (міжнародному, державному, регіональному, місцевому).

Окреслене коло проблем у галузі забезпечення прав дітей в інформаційному середовищі в Україні далеко не вичерпане та може бути продовжене. Проте, перераховані вище проблеми дозволяють констатувати той факт, що в Україні нині назріла необхідність вдосконалення правового механізму забезпечення прав дітей в інформаційному середовищі.

Тому в цьому контексті слід звернутися до позитивного зарубіжного досвіду в окресленій галузі, де в різних країнах існують спеціальні механізми захисту інтересів дітей. Одним 3 інструментів захисту прав дитини в низці зарубіжних країн (СІІА, Канаді, Великій Британії, Бельгії, Франції, Польщі та інших країнах Свропейського Союзу) є формування особливого порядку судочинства щодо неповнолітніх, які вчинили протиправні дії - ювенальна юстиція, що є особливою системою правосуддя для неповнолітніх.

Основною доктриною цієї системи $є$ те, що держава виступає як піклувальник або відповідальна особа за неповнолітніх, 


\section{Адміністративне право}

захищаючи їх від небезпечної поведінки і шкідливого оточення. Нині ювенальні суди діють більше ніж у 60 країнах світу.

Функцію захисту дітей від сімейного насильства у багатьох країнах Європейського Союзу виконують правоохоронні органи у співпраці з органами опіки, піклування, місцевого самоврядування та фахівцями 3 соціальної роботи. У них є досвід постійної та повсякденної роботи 3 сім'ями, які потрапляють в скрутне і навіть небезпечне становище. Соціальний працівник має законне право висунути до винних суворі вимоги.

у Німеччині, Голландії, Великобританії фахівці із соціальної роботи наділені широкими повноваженнями (щодо порушення кримінального провадження та клопотання про позбавлення батьківських прав).

Однак ідея створення ювенальних судів на практиці носить суперечливий характер. У колах ділової громадськості та 3-поміж населення розгораються дискусії та суперечки з цього питання. Формування дієвого правозахисного механізму неповнолітніх в Україні передбачає тривалий процес, де кінцева мета повинна припускати створення такої ювенальної системи забезпечення прав дітей, у тому числі в інформаційному середовищі, яка відповідає міжнародним стандартам.

Законодавець, встановлюючи об'єкт механізму забезпечення прав дітей в інформаційній сфері, виходить із широти цього поняття, включає різні елементи, у тому числі ювенальну юстицію.

\section{Висновки}

Отже, узагальнюючи викладене вище, можемо зробити висновок, що забезпечення прав дітей в інформаційному середовищі як об'єкт правового захисту охоплює сукупність соціальних благ, визнаних державою, які захищаються органами публічної влади, загроза яким тягне можливість застосування заходів державного примусу. Система забезпечення прав дітей в інформаційному середовищі складається 3 різнорідних суб'єктів, уповноважених застосовувати заходи, спрямовані на забезпечення умов морального і духовного благополуччя дітей, заходи психічного примусу, адміністративної відповідальності, які реалізуються через адміністративноправовий механізм забезпечення. Необхідними умовами ефективного механізму забезпечення прав дітей в інформаційному середовищі є закріплення в Конституції України, попередження та мінімізації загроз. Конституційна вимога про гарантії забезпечення прав дітей, у тому числі в інформаційному середовищі прямо сформульована в нормах Закону України «Про захист дитинства». Проведений аналіз дає підстави стверджувати, що законодавець, встановлюючи права людини в інформаційному середовищі як об’єкт правового захисту, виходить із широти цього поняття. Ця обставина є суттєвою підставою реалізації потенціалу застосування відповідного адміністративно-правового механізму забезпечення прав дітей в інформаційному середовищі, але у межах обмежень, встановлених чинним законодавством.

\section{література}

1. Ортинська Н. В. Правовий статус неповнолітніх: теоретико-правове дослідження: дис. ... д-ра юрид. наук: 12.00.01. Аьвів, 2017. 524 с.

2. Єсімов С., Ковалів М., Скриньковський Р., Сопільник Р. Гарантії прав людини та громадянина при забезпеченні інформаційної безпеки. Traektoriâ Nauki= Path of Science. 2018. Vol. 4. № 5. S. 10081016.

3. Опольська Н. Механізм забезпечення прав та свобод людини у динамічному вимір. Підприємництво, господарство і право. 2019. № 4. C. 191-195.

4. Лесько Н. В. Адміністративно-правове забезпечення формування та реалізації державної політики у сфері захисту дітей від насильства та інших протиправних дій: дис. ... д-ра юрид. наук: 12.00.07. Аьвів, 2019. 489 с. 


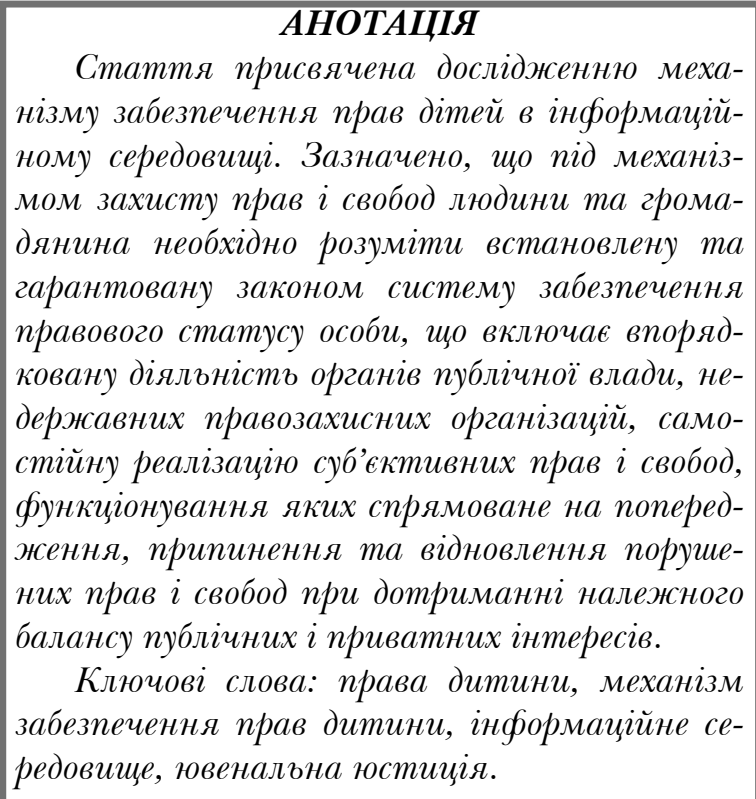

5. Перун Т. С. Адміністративно-правовий механізм забезпечення інформаційної безпеки в Україні: дис. ... канд. юрид. наук: 12.00.07. Аьвів, 2019. 268 с.

6. Ковалів М. В., Єсімов С. С., Лозинський Ю. Р. Правове регулювання правоохоронної діяльності: навчальний посібник. Аьвів: ЛьвДУВС, 2018. 323 с.

7. Про охорону дитинства: Закон України від 26.04.2001 р. № 2402-III. Відомості Верховної Ради України. 2001. № 30. Ст. 142.

8. Про захист суспільної моралі: Закон України від 20.11.2003 р. № 1296-IV. Відомості Верховної Ради України. 2004. № 14. Cт. 192.

\section{SUMMARY}

The article is devoted to the study of the mechanism of ensuring the rights of children in the information environment. It is noted that the mechanism of protection of human and civil rights and freedoms should be understood as a system of legal status of a person established and guaranteed by law, which includes orderly activities of public authorities, non-governmental human rights organizations, independent realization of subjective rights and freedoms. prevention, termination and restoration of violated rights and freedoms while maintaining the proper balance of public and private interests.

It is established that the design of the mechanism for ensuring the rights of children in the information environment includes: regulatory certainty (enshrined in the legal act); bodies (system of bodies) of public power, endowed with the functions of ensuring the rights of children in the information environment; a system of indicators, reporting and centralized collection of information that reflects the state of practice of administrative and legal support of children's rights in the information environment; special measures of administrative and legal support of children's rights in the information environment; the existence of norms that provide for legal liability for encroachment on protected relations; other measures to ensure the rights of children in the information environment related to social adaptation; aimed at informing about the negative consequences (legal, medical, social, etc.), antisocial phenomena; aimed at strengthening and protecting the family; ban on propaganda and advertising of antisocial phenomena; interaction of executive bodies with the public (including volunteer organizations); specialized social assistance; psychological support of children's rights in the information environment; spiritual (religious) provision of children's rights in the information environment.

The gradation of groups of norms regulating the provision of children's rights in the information environment, according to the target orientation and functions, is proposed. It was emphasized that the formation of an effective human rights mechanism for minors in Ukraine involves a long process, where the ultimate goal should be the creation of such a juvenile system for children's rights, in particular in the information environment that meets international standards.

Key words: children's rights, mechanism for ensuring children's rights, information environment, juvenile justice. 


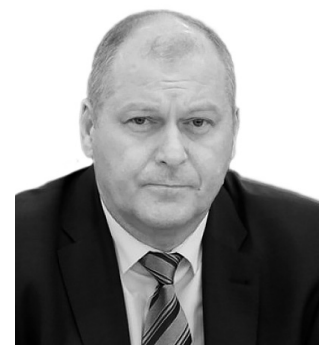

\section{МОТИВАЦІЯ ІНДИВІДУАЛЬНОї ЗЛОЧИННОӤ ПОВЕДІНКИ, ПОВ'ЯЗАНОї 3 ТЕРОРИЗМОМ}

ДАНИЛЬЧЕНКО Юрій Брониславович - доктор юридичних наук, доценТ, старший науковий співробітник Науково-дослідного інституту вивчення проблем злочинності імені академіка В.В. Сташиса Національної академії правових наук України

УДК 343.9:323.28

DOI 10.32782/LAW.2020.3.12

\section{Постановка проблеми}

Однією з початкових ланок механізму злочинної поведінки виступає період формування мотивів злочину. При цьому, як усі ми розуміємо, під мотивом зазвичай визнають внутрішне спонукання до того чи іншого вчинку. Його, тобто мотив, часто розглядають як безпосередню причину вчинення злочину. Можливо наголосити на тому, що вивчення мотиву відповідає на питання, чому людина чинить так чи інакше. Це, так би мовити, аксіома.

Мотив злочину, як наголошує I. О. Бандурка, взагалі розглядається як безпосередня внутрішня рушійна причина злочинного діяння, як-то: помста, користь, ревнощі, конкуренція, захист тощо. Мотив є елементом суб'єктивної сторони злочину і кваліфікуючою ознакою злочину, що може бути як пом'якшуючою, так і обтяжуючою обставиною під час визначення покарання. Термін «мотивація» вживається найчастіше у таких двох розуміннях:

- як система факторів, що спонукають активність людини й обумовлюють спрямованість її поведінки; до них належать такі психічні утворення, як потреби, мотиви, цілі, інтереси і т. ін.;

- як характеристика процесу, який забезпечує поведінкову активність на певному рівні, етапі чи стадії й у відповідній ситуації, інакше кажучи, мотивування [1, c. 101-102].
Проблема встановлення змісту мотивації особи, яка стає на шлях терористичної діяльності є вельми актуальною на цей час. Сучасне суспільство, при цьому не тільки українське, знаходиться постійно під загрозою нанесення терористичних атак у різних сферах і з різних сторін. Тому отримати відповідь на питання про те, що виступає мотиваційною складовою індивідуальної злочинної поведінки, яка пов'язана $з$ вчиненням терористичного акту, є вкрай необхідним для людства.

\section{Аналіз останніх досліджень та публікацій}

Проблемою мотивації та обумовлення терористичної діяльності свого часу займались вітчизняні та зарубіжні дослідники, а саме: Ю. М. Антонян, В. С. Канцір, О. Ю. Конєв, I. Аєбєдєв, В. Пирожков, ᄉ. М. Сукмановська тощо.

Нами, свого часу, у межах дисертаційного дослідження «Тероризм: феномен, детермінація, протидія» також піднімалась проблема мотивації терористичної діяльності, але стрімкий розвиток суспільства постійно тягне за собою і поновлення механізму індивідуальної злочинної поведінки, а разом з ним і змінюе мотивацію такої поведінки. Іншими словами, мотивація терористичної діяльності постійно знаходиться в певному динамічному русі; постіно, певною мірою, «перероджується», внаслідок чого існує потреба поновлюва- 
ти погляд на це питання і реалізовувати аналіз сучасної ситуації у сфері виникнення терористичної діяльності.

\section{Мета статті}

Метою наукової статті є з'ясування основного змісту мотивації індивідуальної злочинної поведінки, пов'язаної 3 тероризмом, та визначення характерних мотивів, які спонукають особу на вчинення терористичного акту.

\section{Виклад основного матеріалу}

Починаючи розгляд мотивації індивідуальної злочинної поведінки пов'язаної 3 тероризмом, вважаємо за доцільне проаналізувати вже сучасні точки зору на цю проблему.

Так, свого часу I. Аєбєдев наголошував на тому, що основні мотиви злочинної поведінки особи, яка вчинюе діяння, пов'язане $з$ тероризмом, напряму обумовлені світоглядом терориста; його інтересами, соціальними орієнтаціями; вмінням, навичками та звичками; наявністю стереотипів поведінки, установки тощо [2, с. 97]. Інший відомий кримінолог Ю. М. Антонян, досліджуючи сутність тероризму 3 точки зору кримінологічної та кримінально-правової науки, зазначив, що, як і безліч інших людських вчинків, мотивація тероризму має складний, багаторівневий, неоднозначний характер, а самі мотиви необхідно розрізняти залежно від особи й видової приналежності конкретного терористичного акту [3, с. 251].

Відомий дослідник у галузі юридичної психології доктор психологічних наук В. Ф. Пирожков під час круглого столу присвяченого проблемі феномену тероризму наголошував на тому, що терорист у момент вчинення терористичного акту видається собі мужнім, благородним, жорстоким, безкомпромісним борцем за справедливість. "Політичному» терористу здається, що в ім'я досягнення справедливості в його розумінні можуть і повинні приноситися в жертву життя інших людей. «Економічний» терорист переконаний, що дії його конкурента $є$ несправедливими й вимагають «крайніх заходів». «Психологічному» терористу здається, що суспільство не дозволило реалізувати закладені у ньому можливості, і він може «піти в небуття» невідомим, а здійснюючи терористичний акт, він не лише реалізує можливості влади над людьми, а й прославиться навіки своїм мужнім вчинком... У який би одяг не одягалися терористи, яку б мету не переслідували (політичну - захоплення влади, зміну суспільного устрою; моральну - досягнення «справедливості», яка не завжди правильно (хибно, неадекватно) ними розуміється; економічну - вбивство конкурентів; релігійну - обстоювання чистоти віри; психологічну - стати відомим, прославитися, залишити слід в історії тощо) - за всім цим стоять намагання відчути владу над людьми» [4, с. 33].

Один 3 відомих сучасних українських дослідників тероризму В. С. Канцір, на підставі аналізу суб'єктивних мотивів, якими, за висловлюванням самих терористів, керувались люди, які хоча 6 раз брали участь у терористичному акті, виділяє такі групи мотивів:

- меркантильні - терор, як і будь-яка інша сфера людської діяльності, є оплачуваною працею, відповідно, для певного кола людей це заняття - своєрідний спосіб заробітку;

- ідеологічні мотиви - більш стійкі, що грунтуються на збігу власних цінностей людини та їі ідейних позицій з ідеологічними цінностями групи, організації чи політичної партії;

- мотиви перетворення, активної зміни мапи світу, що пов'язано з розумінням недосконалості й несправедливості сучасного світу та наполегливим намаганням покращити, перетворити його;

- глибинний мотив, коли насильство застосовується для утвердження особистої влади, через насильство терорист утверджує себе та свою особистість, набуваючи влади над людьми;

- мотив зацікавленості та привабливості терору як сфери діяльності; для пев- 


\section{Кримінальне право, кримінальний процес та криміналістика}

ного кола осіб, особливо забезпечених i достатньо освічених, терор стає цікавим просто як нова, незвична сфера занять, їм до вподоби пов'язаний із тероризмом ризик розроблення планів, можливі деталі підготовки, тонкощі його здійснення;

- «товариські» мотиви емоційної прив'язаності в різних варіантах - від мотиву помсти за шкоду чи образу, завдану товаришам по боротьбі, одновірцям, родичам, соратникам у політичній діяльності тощо, до традиційної участі в терорі, тому що ним займається хтось із друзів, родичів, соратників тощо;

- мотив самореалізації (парадоксальний мотив); самореалізація, з одного боку, прерогатива сильних духом людей, найповніше розкриття особистості, іiі повна самовіддача, розчинення людини в терористичному акті, аж до самопожертви, однак, з іншого боку, така самореалізація - визнання обмеженості можливостей i констатація неспроможності людини, яка не знаходить інших способів вплинути на світ, окрім насильства та деструкції, така самореалізація призводить, як правило, до самознищення й означає насамперед визнання факту психологічної деструкції особистості [5, с. 298-299].

Graeme R. Newman ta Ronald V. Clarke у своєму науковому дослідженні «Policing terrorism: an executive's guide» («Політика тероризму: посібник для керівників») виділили три основних мотиви терористичної діяльності. Перший визначається ними як культурологічний. Сутність цього мотиву полягає в тому, що за логікою терористів, будь-яке суспільство необхідно час від часу «збуджувати», тобто турбувати його. При цьому, найкращим шляхом такої турботи є кровопролиття. Другий - раиіональний. Мова йде про те, що терор, як форма злочинної діяльності, трактується як ефективний інструмент політичної діяльності. Третій - $і д е$ ологічний. Сутність цього мотиву полягає в тому, що він передбачає терор як зброю регуляції соціальних процесів у суспільстві.
При иьому, вчені підкреслюють той бакт, що теорія і практика тероризму кардинально різняться між собою. Теоретично тероризм «зрівнює» людей $i$ групи, а в сочіальній практиці протиставляє їх один одному, вибудовуючи між ними стіну страху [6].

Дослідниками помічено, що в осіб, які скоюють терористичні злочини, мотиви акумулюються у двох напрямах. У першому випадку мова йде про те, що всі його дї прагнуть до реалізащї власних помислів $і$ думок, які пов'язані з метою його діяння, а саме - реалізачія терористичного акту. У другому випадку, мова йде про задоволення потреби такоӥ особи в насильстві, яке, у свою чергу, є невіддільною від агресї та жорстокості особи терориста. Аналіз мотивів злочинної поведінки особи-терориста потрібен не тільки для усвідомлення змісту конкретного терористичного акту та бакторів, шоо його обумовлюють, але $і$ для розкриття сутності всъого явища тероризму в иілому. Розуміння психологї тероризму дозволяе нам чітко акцентувати власну увагу на тому, що нам потрібно для розуміня того, від кого можливо чекати відповідних дій, хто e терорист як особистість, як попередити та розслідувати злочини, пов'язані з терором $і$ як притягувати до відповідальності винних осіб.

Під час нашого дослідження проблеми мотивациї індивідуальної злочинно ̈ поведінки, пов'язаної з тероритичною діяльністю, нас не залишало певне питання: яку вигоду отримує терорист від здійснення відповідного акту, в тому иислі й у випадку, коли він робить ие за матеріальну винагороду? Адже корисливі стимули, на нашу думку, тільки зовні виглядають природними мотивами, а під ними, в глибині, на підсвідомому рівні, бункціонують ще інші, не менш потужні спонукання, які иасто є головними.

Намагаючись дати відповідь на ие запитання, ми логічно зіштовхувались з іншим. При аналізі мотивачійної основи терористичної діяльності завжди виникає запитання: які бактори, явища або подї лягають в основу тих мотивів, що спонукають особу до вчинення терористичного акту. У иій ситуаиї можливо виділити найбільш характерні: 
- чинники психопатологічного характеру. Про що йдеться мова? Серед дослідників сутності тероризму як явища та механізму його окремих проявів постійно виникає дискусія з приводу того, які особи-терористи за своїм психічним станом домінують в загальній сукупності. Тобто, терорист - ие психічно здорова людина чи з певними психічними відхиленнями чи то аномаліями? У изій ситуацї, на нашу думку, необхідно розуміти те, що взагалі в межах терористичної діяльності присутні обидві категоріі осіб, але перша категорія, тобто здорова людина, зустрічається нам набагато частіше, ніж особа з психічними розладами;

- мотиви самоутвердження, молодіжної романтики та геройки, надання свойй діяльності особливої значимості, подолання відчуження, стандартизаціӥ. Дуже часто, особливо серед молоді, яка з певних причин опинилась у сбері розповсюдження терористичноі діяльності, існує бажання тим чи іншим чином виділитись серед однолітків, перевірити власні можливості. У иьому випадку згадується внутрішня боротьба, яка точилась у свідомості Родіона Раскольнікова - героя всесвітньо відомого соиіально-психологічного та сочіально-філособского роману Ф. М. Достоєвського "Престуление и наказание». Тільки одне питання було в голові изєї людини, а саме: «Тварь я дрожащая, или право имею?». Яке, у свою чергу, і привело його до злочину убивства;

- корисливі мотиви, які можуть витіснити ідейне підгрунтя терористичної діяльності або тісно переплестися з ними. Як ие не прикро чути особам, які базують свою діяльність на тих чи інших ідеологічних постулатах, дуже часто в поведіниі, яку вони пропагують, знаходить своє місие $і$ корисна складова. Іншими словами, поряд з тією чи іншою ідеєю дуже часто виникає бажання в осіб задовольняти свої власні потреби за рахунок иієї $і$ деолгї. Терористична діяльність, яка має ідеологічне обгрунтування, також «хворіє таким недугом". Дуже часто мотивачійна основа терористичного прояву пов'язана з бажанням отримати винагороду в тій чи іншій бормі;
- ідеологічні мотиви. Дуже часто тероризм є результатом «твердого» переконання у володінні природною, вищою, кінщевою істиною, унікальним рецептом урятування свого народу або навіть усъого людства (ідейний абсолютизм) від певной загрози. Дуже часто в свідомості особи-терориста формується думка про бакт існування певної загрози своєму народові або навіть людству. При изьому, єдиним спасінням від иієї небезпеки доля обирає його як єдиного рятівника людства.

При цьому, необхідно наголосити на тому, що чітко обумовлюваних факторів однієї спрямованості в процесі формування мотивів індивідуальної злочинної поведінки, яка пов'язана 3 терористичною діяльністю, в об'єктивній реальності не існує. Усі вони тим чи іншим чином перетинаються один 3 одним і утворюють комплекс явищ, що формують мотиваційну складову такого механізму індивідуальної злочинної поведінки. Безумовно, залежності від кожного окремого випадку, та чи інша група вищезазначених нами явищ набуває відповідного пріоритету для особи, яка вчиняє терористичний акт.

Якщо наголошувати на значенні мотивів для інших складових елементів механізму індивідуальної злочинної поведінки, то без будь-яких сумнівів вони, тобто мотиви, тісно пов'язані зі способом учинення діяння або із засобом досягнення кримінальної мети. Як наголошує В. С. Канцір, існує безпосередній зв'язок між мотивом і спрямованістю наміру. Насильство у вигляді тероризму може виступати і як спосіб, і як засіб досягнення кримінальної мети. Характер такого насильства визначається з урахуванням його мотиву. У цьому проявляється особлива специфіка тероризму, якщо простежити зв'язок саме способу діяння й мотиву [5, с. 302].

У свою чергу, морально-прикладний аспект тероризму як явища полягає у тому, що він відрізняється від інших видів насильства не просто жорстокістю, а вищим ступенем аморальності, нерозбірливості у засобах, некерованістю. Якщо терорист вважає, що треба знищити обрану 


\section{Кримінальне право, кримінальний процес та криміналістика}

жертву, то це слід зробити так, щоб убивство справило певне враження на оточення та залякало його. Нерідко великий резонанс після терористичного акту буває важливішим за сам акт. Будь-яка особа, що безпосередньо зіштовхнулася з наслідками теракту, мимоволі може уявити себе на місці жертви, звісно, це матиме сильний психологічний ефект, тим більше, що часто жертвами стають випадкові люди [7, c. 52].

Найбільшу цікавість викликає питання про те, чи є терористична поведінка результатом раціонального вибору, зробленого на підставі ретельного аналізу співвідношення витрат і вигоди, або ж їі викликано психічними силами, над якими сам терорист не владний. Останне може охоплювати емоційне потрясіння, якого він зазнав у дитинстві, нічим не стримуване бажання діяти, фрустрацію 3 приводу питань ідентичності тощо. Цілком зрозумілим є прагнення відокремити терористів від «нормальної» частини людства, проте, незважаючи на значне поширення розмов про «безглузде» насильство, яке вчиняється «божевільними» терористами, існують переконливі наукові свідчення того, що вони «нормальні» за своїми психологічними характеристиками й поведінкою, яка передувала вчиненню актів насильства. Навіть терористи-смертники, щодо яких проведено численні дослідження, загалом мали нормальну психіку [8, с. 224].

\section{Висновки}

Підсумовуючи викладене вище, хотілось наголосити на наступному:

- мотивація як психофізіологічний процес, що керує поведінкою людини; що задає його спрямованість, організацію, активність і стійкість; що створюе здатність людини активно задовольняти свої потреби виступає невід'ємною частиною механізму індивідуальної злочинної поведінки;

- мотивачія індивідуальноӥ злочинної поведінки, пов'язаної з тероризмом базується на загальновизнаних постулатах теорї обу- мовлення окремого злочину та розглядається як окремий елемент відповідного механізму індивідуальної злочинної поведінки;

- мотивація індивідуальної злочинної поведінки, пов'язаної з тероризмом базується та бормується на обумовлюваних чинниках психопатологічного характеру; мотивах самоутвердження, молодіжної романтики та героїки, надання своїй діяльності особливої значимості, подолання відчуження, стандартизачї; корисливих мотивах; ідеологічних мотивах;

- усе підгрунтя мотивації індивідуальноӥ злочинної поведінки, пов'язаної з тероризмом, носить комплексний характер та демонструє взаємозв'язок однієї групи факторів з іншою, але, при иьому, зберігається пріоритетність таких груп для кожного випадку окремо, в межах якого та чи інша група вищезазначених нами явищ набувае відповідного пріоритету для особи, яка вчиняє терористичний акт.

\section{Лiтература}

1. Кримінологія. Академічний курс/за заг. ред. О. М. Аитвинова. Кол. авторів. К.: Видавничий дім «Кондор», 2018. 588 с.

2. Лебедев И. А. Характеристика личности осужденного за терроризм. Человек: преступление и наказание. 2005. № 3 (51). C. 95-100.

3. Антонян Ю. М. Терроризм: криминологическое и уголовно-правовое исследование: монография. М.: Щит-М, 1998. $306 \mathrm{c}$.

4. Психологи о терроризме («круглый стол»). Психологический журнал. 1995. Т. 16, № 4. C. 33-37. URL: https://psyfactor.org/ terror3.htm (дата звернення: 29.09.2020).

5. Канцір В. С. Спонукальні мотиви терористичної діяльності. Науковий вісник Аъвівсъкого ДУВС. 2012. № 1. С. 294-303.

6. Newman Graeme R. Policing terrorism: an executive's guide / by Graeme R. Newman and Ronald V. Clarke. Washington, DC: U.S. Dept. of Justice, Office of Community Oriented Policing Services, Center for Problem-Oriented Policing, 2008. - 134 p. URL: https://books.google.com.ua/ books?id $=8 \mathrm{Mcpf0rbXCIC \& printsec}=$ frontc 


\section{АНОТАЦІЯ}

Статтюо присвячено проблемі встановлення змісту мотивацї індивідуальної злочинної поведінки, пов'язаної з тероризмом. Наголошується на важливості базування процесу формування мотивачї̈ даного виду злочинной діяльності на чинниках психопатологічного характеру; мотивах самоутвердження та молодіжної романтики та героїки; корисливих мотивах; ідеологічних мотивах. Робиться висновок про те, що мотивачія індивідуальной злочинної поведінки пов'язаної з тероризмом, носить комплексний характер та демонструє взаємозв'язок однієі групи ббакторів з іншою.

Ключові слова: мотив, мотивація, тероризм, індивідуальна злочинна поведінка

over $\& \mathrm{hl}=\mathrm{ru} \# \mathrm{v}=$ onepage $\& \mathrm{q} \& \mathrm{f}=$ false $\quad($ дата звернення: 12.10.2020).

7. Тероризм: теоретико-прикладні аспекти: навчальний посібник / кол. авторів ; за заг.ред. проф. В. К. Грищука. Львів: ЛьвДУВД, 2011.328 с.

8. Конев О. Ю. До питання про деякі психологічні фактори, що спричиняють терористичну діяльність. Південноукраїнсъкий правничий часопис. 2014. № 4. С. 224225. URL: file://C:/Users/8FEE 1/AppData/ Local/Temp/Pupch_2014_4_70.pdf (дата звернення: 15.10.2020)

\section{SUMMARY}

The problem of establishing the content of the motivation of a person who embarks on the path of terrorist activity is very relevant at this time. Modern society, not only Ukrainian, is constantly under threat of terrorist attacks in various spheres and from different directions. Therefore, to answer the question of what is the motivating component of individual criminal behavior, which is associated with the commission of a terrorist act, is a must for humanity.

The purpose of the scientific article is to clarify the main content of the motivation of individual criminal behavior related to terrorism and to determine the characteristic motives that motivate a person to commit a terrorist act.

The main content of the article emphasizes that motivation, as a psychophysiological process that controls human behavior; that sets its focus, organization, activity and stability; which creates the ability of a person to actively meet their needs is an integral part of the mechanism of individual criminal behavior. In this case, the motivation of individual criminal behavior related to terrorism is based on the generally accepted postulates of the theory of conditioning a particular crime and is considered as a separate element of the relevant mechanism of individual criminal behavior. In addition, it is based and formed on the causes of psychopathological nature; motives of self-affirmation, youth romance and heroism, giving special significance to their activity, overcoming alienation, standardization; selfish and ideological motives.

It is concluded that all the grounds for the motivation of individual criminal behavior related to terrorism is complex and demonstrates the relationship of one group of factors with another, but, while maintaining the priority of such groups for each case separately within which one or another the group of phenomena mentioned above acquires the appropriate priority for the person who commits a terrorist act.

Keywords: motive, motivation, terrorism, individual criminal behavior 


\title{
МАЙБУТНІЙ ПОГЛЯД НА ОРГАНІЗАЦІЮ БЕЗПЕКИ: ФОРСАЙТ БЕЗПЕКИ І ЯК НИМ КОРИСТУВАТИСЯ
}

\author{
ЛИСЕНКО Сергій Олексійович - доктор юридичних наук, професор, ПрАТ \\ «Вищий навчальний заклад «Міжрегіональна Академія управління персоналом», \\ завідувач кафедри правознавства Сєвєродонецького інституту \\ ORCID ID: https://orcid.org/0000-0002-7050-5536 \\ DOI 10.32782/LAW.2020.3.13
}

Статья посвящена новому взгляду на современнъий метод реконструкиии модели безопасности организации, которьий основан на активном использовании борсайта безопасности. Рассмотренъг генезис бормирования борсайта безопасности и особенности его применения в современнъгх условиях.

Форсайт безопасности рассматривается как инструмент прогнозирования и бормирования будущей модели безопасности организаици, позволяюший в короткие сроки получить достаточно точнъе прогнозъ возможнъгх рисков и недостатков в развитии организачии в долгосрочной перспективе.

Бълло заявлено, что форсайт безопасности позволяет не только прогнозировать возможнъие угрозы и положительнъе последствия, но и вълявлять различнвие сценарии будущего. Определено, ито главнъим преимуществом борсайта, как инструмента безопасности, является способность осознать, что именно нужно делать сейчас, чтобъ будущий мир соответствовал самвим оптимистичнъим прогнозам.

Акцент делается на существовании в современной практике безопасности двух борматов борсайта безопасности, различаюшихся по масштабу. Формат менъшего масштаба, или «локальнъий борсайт», предполагает отдельную борсайт-сессию для прогнозирования явления. Более крупнъий бормат, предполагающий большое количество специалистов, проводящих серию борсайт-сессий, требует надлежащего административно-правового регулирования, что определяет одно из важнъх направлений дальнейших исследований в этой области.

Автор анализирует особенности использования форсайта на примере карантинных мер, направленнъхх на противодействие пандемии COVID-19 и прогнозирования угроз, исходящих как от самой эпидемии, так и от мер по борьбе с ней.

Особое внимание уделяется описанию новой пробессии - «посредника по безопасности», как лица, работающего в службах безопасности или отдельной фирме, которое вместо основных лич, находящихся в самоизоляиии, будет присутствовать при подписании международнъхх соглашений по вопросам безопасности, связанных, в том числе, с культурнъими особенностями участников.

Ключевъе слова: Форсайт; борсайт безопасности; прогнозирование угроз; будущее; экспертная деятельность; административно-правовое регулирование; COVID-19; посредник по безопасности.

Актуальність теми дослідження

Наше уявлення про майбутне постійно змінюється залежно від прогресу, що обумовлюе не лише розвиток технологій, але й еволюцію свідомості та світосприйняття сучасної людини. Стрімкі зміни інформаційно-комп'ютерних систем поєднуються з глобалізаційними процесами, що породжує справжній вир подій, які, на перший погляд, можуть видаватися непередбачуваними. Водночас, разом із цим реально змінюється рівень загроз у дію- 
чих організаціях, що обумовлює потребу розробки та впровадження нових методів прогнозування, виявлення та протидії цим загрозам.

Наявний наразі перелік методик для аналізу та виявлення загроз безпеці є доволі різноманітним. Автором неодноразово висвітлювались адміністративно-правові особливості реконструкції як одного із таких заходів. Однак останнім часом методика реконструкції знайшла своє продовження та вдосконалення. Очевидно, що в провідних країнах цю думку розвинули дуже якісно та грунтовно, навіть надали цьому заходу оригінальну назву - форсайт безпеки.

\section{Аналіз попередніх досліджень даної тематики}

На пострадянському просторі форсайт, як явище та інструмент прогнозування, досліджували I. Баришев, Р. Кравець,I. Кірнос, С. Кукушкіна, С. Серьогіна, Особливої ж уваги проблематика форсайту набула у працях таких західних дослідників, як A. Clayton, G. Muller, R. Phaal, N. Taleb. Водночас, проблематика форсайту безпеки лишається малодослідженою та потребує уваги науковців, які представляють різні галузі знань.

Метою дослідження є висвітлення нового погляду на сучасну методику реконструкції моделі безпеки організації, яка базується на активному застосуванні форсайту безпеки.

\section{Основний зміст дослідження}

Сьогодні для визначення гіпотетичних позитивних і негативних сценаріїв розвитку в організаціях спеціалісти дедалі частіше вдаються до так званого «форсайту безпеки». Форсайт (англ. Foresight - «передбачення») - це технологія і формат комунікації, що дозволяють учасникам домовитися 3 приводу образів майбутнього, а також, визначивши бажаний образ, узгодити дії в його контексті $[1,2]$. Автор у своїх попередніх публікаціях розкривав особливості адміністративно-правових та стратегічних умов використання перспективної рекон- струкції для забезпечення безпеки організацій [3]. Aле в даному випадку мова йде про більш досконалу версію авторської перспективної реконструкції, яку вже зараз активно використовують західні фахівці у галузі безпеки.

Історично, вперше термін «foresight» запропонував відомий письменник-фантаст Герберт Уеллс. Ще у 1930 р., виступаючи на ВBC, він запропонував впровадити особливу спеціальність - «професор передбачення», який, подібно до історика, буде аналізувати і знаходити застосування майбутнім технологічним відкриттям [2]. Як і чимало інших передбачень, зроблених письменниками-фантастами початку XX століття, це стало значною мірою пророчим. Якщо говорити про Форсайт безпеки, як про глобальний дослідницький проект закордонних (переважно - західних) фахівців 3 безпеки, то ця методика сягає своїм корінням у 50-ті роки ХХ століття. Вперше їі прототип було впроваджено в CIIA корпорацією RAND, яка була стратегічним дослідницьким центром, що працював на замовлення уряду і збройних сил СIIA. У подальшому технологія набула поширення у Південній Кореї, Японії та ряді країн НАТО. Спочатку це була важка і досить дорога технологія прогнозування у сфері безпеки, у рамках якої протягом місяців працювала величезна кількість експертів [4].

Наразі можна уявити чимало різних модифікацій форсайту безпеки. Так швидкий Форсайт безпеки (англ. Rapid Foresight sequrity) - це інструмент для прогнозування і формування майбутньої моделі безпеки організації, що дозволяє не лише за короткий період часу отримати доволі точні прогнози про можливі ризики та недоліки в розвитку організації, але й об'єднати людей, скоординувавши їх діяльність для реалізації отриманих уявлень про бажаний сценарій розвитку подій [4].

У попередніх дослідженнях, у процесі аналізу інформації в рамках перспективної реконструкції, автором виокремлювалося кілька способів (підходів) до організації мислення, такі як: екстраполяція; моделювання; форсайт; футурологія 


\section{Кримінальне право, кримінальний процес та криміналістика}

тощо [5]. Проте із усіх перелічених саме «форсайт-сесії із залученням експертів 3 безпеки часто виявляються незрівнянно більш ефективним інструментом, ніж, наприклад, просте екстраполювання на майбутне вже наявних даних про минулі загрози та ризики. Отож, форсайт безпеки пов'язаний не стільки 3 прогнозуванням, скільки 3 проєктуванням певної моделі безпеки організації. В його основі лежить розуміння того, що майбутня безпека варіативна і безпосередньо залежить від впроваджених заходів. Тому головне завдання, яке варто вирішити суб'єктам безпеки, можна сформулювати як: встановлення певного алгоритму заходів, які спільними зусиллями слід зробити вже зараз для того, щоб прийти до бажаного результату в майбутньому. Автор упевнений у тому, що форсайт безпеки може допомогти підготувати суспільство для безпечного життя прийдешніх поколінь.

Окрім зазначеного, у форсайті безпеки важливу роль відіграє оцінка загроз, що характеризуються низькою ймовірністю виникнення, але при цьому мають великий потенціал негативного впливу на майбутне досліджуваної організації. Загальносвітова пандемія COVID-19 - яскравий приклад подібної події. Такі загрози називають «чорними лебедями», за визначенням одного 3 найвідоміших філософів сучасності Нассіма Талеба [6]. «Чорні лебеді»-це точки біфуркації, які є настільки прихованими від поверхневого аналізу, що їх можливо виявити лише на обговореннях на кшталт форсайт-сесій з безпеки, при чому лише за умови залучення до цієї проблеми достатньої уяви.

Про те, що в сучасному світі людям дедалі частіше загрожуватимуть не світові війни, а саме епідемії, свого часу попереджали багато футурологів. Зрозуміло, що вони не говорили саме про 2020 рік і саме про групу «корона вірусів», а тим більш - про COVID-19. Але вони неодноразово підкреслювали, що ми вступаємо в такий світ, у якому інфекції можуть стати більш небезпечною загрозою, ніж раніше. Це видавалося парадоксальним, оскільки в XX столітті впровадженням санітарних захо- дів, щеплень і антибіотиків нібито вдалося подолати, або принаймні - взяти під контроль більшість небезпечних хвороб. Aле водночас, саме на початку XXI століття ми, як ніколи раніше, живемо скупчено, багато подорожуємо. До того ж, наш світ є ще більш неоднорідним, ніж будь-коли, адже поруч з високорозвиненими існують слаборозвинені країни.

Важливо розуміти, що такі події, які можна віднести до категорії «чорних лебедів», дуже рідко відбуваються всупереч наявним глобальним загрозам або ж кардинально змінюють їх. Найчастіше - вони їх посилюють. Наприклад, якщо говорити про тотальний перехід різних сфер діяльності організації в онлайн площину, який набув поширення саме в процесі протиепідемічних ізоляційних заходів протягом 2020 року, то ^юди так чи інакше до цього йшли і до появи епідемії COVID-19. Поява та поширення нових телекомунікаційних технологій дедалі більше підвищували для організацій загрозу викрадення або пошкодження конфіденційної чи службової інформації, шляхом впливу з мережевого простору. Багато завдань з безпеки відходили на аутсорсинг, фріланс, і дедалі більше організацій віддавали перевагу оренді офісів на короткий час замість облаштування постійного місця для своєї діяльності, що теж негативно позначалося на рівні безпеки таких організацій. Усі перелічені загрози не виникли внаслідок пандемії COVID-19. Але саме завдяки пандемії ці загрози раптово посилилися.

Вже сьогодні зрозуміло, що коли карантин закінчиться, вийдуть 3 нього не всі. Адже багато людей по всьому світу продовжать працювати $з$ домівок, тому що вони вже налагодили собі повноцінне робоче місце. I якщо бути чесними, то так і зручніше, і дешевше. Це може не подобатися деяким керівникам, для яких притаманний консервативний підхід до організації праці, і прагнення до візуального контролю. Але реальність диктує свої умови, i ті, хто не вміє їх розуміти, програють конкурентну боротьбу. За великим рахунком, саме карантин протидії COVID-19 став своєрідним заходом тотальної сегре- 
гації видів діяльності на такі, які можливі в дистанційному режимі, і такі, які потребують фізичної присутності працівників/ службовців. I в такому, несподівано новому суспільстві способи та методи роботи суб'єктів з безпеки зміняться докорінно.

Тут важливо розділяти кілька принципово важливих моментів. Говорячи про форсайт безпеки, часто мають на увазі трохи різні речі. Найчастіше під цими словами мають на увазі саме форсайт-сесії фахівців з безпеки. Зазвичай у таких заходах беруть участь експерти, модератор, який веде процес і секретар, який стежить за ходом дискусії і веде всі записи. Оптимальне число учасників - від 7 до 15 осіб, а час на обговорення зазвичай не перевищує кількох днів [7].

Натомість, форсайт безпеки, як глобальний дослідний проєкт, будується складнішими адміністративно-правовими засобами, завдяки яким стає можливо організувати такий складний процес.У його рамках спочатку, як правило, проводяться попередні дослідження і моніторинги, на основі яких будуються гіпотези, і тільки після цього організовуються обговорення групами експертів 3 безпеки. Такі фахівці починають вибудовувати на основі попередніх висновків та фактів шлях до майбутньої моделі безпеки, прогнозувати, проєктувати дорожні карти i домовлятися. При цьому однієї форсайтсесії з безпеки може виявитися недостатньо, і в такому разі планується ряд додаткових. Такі дослідження можуть тривати досить довго і включати в себе участь дуже великого числа фахівців, навіть - 3 кількох країн [8]. Зрозуміло, що без належного адміністративно-правового регулювання, буде доволі складно забезпечити такий масштабний та тривалий процес. Крім цього, важливу роль у форсайті безпеки відіграє підбір експертів, до яких висуваються певні адміністративно-правові вимоги. У першу чергу, фахівці самі повинні бути зацікавлені в дослідженні і готові до подальших конкретних дій, а головне, в межах конкретної організації повинен підтримуватись режим конфіденційності.
Таким чином, можна вести мову про два формати форсайту безпеки, які відрізняються масштабністю. Але в рамках будь-якого форсайту безпеки проводиться аналіз тенденцій виникнення загроз, технологій їх створення і методів їх запобігання, які можуть розвинутися в даний час у певній галузі. Наприклад - зростає кількість безробітних громадян, усе більше людей працюють 3 дому або з'являється все більше систем, заснованих на великих базах даних. Усе залежить від того, що конкретно аналізують фахівці. Коли починає вимальовуватися карта змін, група прогнозує, до чого саме може призвести у майбутньому розвиток визначених загроз. Тут завжди і вимальовується найцінніший продукт форсайту: одні й ті самі прогнозовані процеси комусь можуть принести користь, а комусь - саме очікувану загрозу.

Використовуючи попередній приклад, уявімо, що збільшення числа безробітних загрожує роботі торгових підприємств, які завжди розраховують на купівельну спроможність населення. Проте, в той же час, ця ситуація дає нові можливості роботодавцям, здешевлюючи робочу силу. Також це може спричинити за собою появу нових сфер діяльності або популяризації вже наявних, але раніше не настільки затребуваних, які стануть активно освоювати безробітні і власники застарілих професій. Звичайно, це буде також корисним всілякого роду навчальним закладам та бізнестренерам. I, таким чином, перебираючи можливі загрози і методики, аналітична група приходить до певного образу майбутнього, де виокремлено як загрози, так і потенціал.

Після цього робляться так звані «ставки» на те, що кожен з учасників готовий почати робити прямо зараз. Це може бути залучення інших фахівців, застосовування запланованих раніше методів боротьби або залучення силових органів влади. Тобто використання будь-яких ресурсів, щоб прийти до потрібного варіанту майбутнього. Наприклад, якщо ми хочемо, щоб у 2030 році всі країни перестали добувати нафту, потрібно вже зараз думати над впровадженням зелених джерел енергії, 


\section{Кримінальне право, кримінальний процес та криміналістика}

тому що їх впровадження потребує значного часу. I якщо цього не почати робити прямо сьогодні, то за кілька років настане вже інший варіант майбутнього.

У кожній сфері людської діяльності, і навіть у кожній окремій організації існує свій спектр прогнозування i життєвий цикл. В індустрії моди, наприклад, він відносно короткий, і будувати перспективну реконструкцію (тобто - форсайт безпеки) далеко вперед просто не має сенсу, тому що все може швидко змінитися. Те ж саме стосується мобільних додатків або ігрової індустрії.

Протилежною виглядає ситуація в атомній енергетиці, де керівники галузі мають мислити поняттями на кшталт «П'ятдесят років і більше». I говорити там в межах річного i навіть десятирічного прогнозу безглуздо, тому що за цей час нічого важливого та нового не відбудеться, а те, що зміниться, швидше за все, вже було раніше сплановано чи спрогнозовано.

Необхідно розуміти, що створений форсайтом безпеки перспективний план не $є$ статичною догмою, до нього потрібно постійно повертатися і робити його корекцію $з$ урахуванням того, що вже сталося. При цьому, ретельно і в точності вгадувати всі загрози, завдання не стоїть $[7,8]$.

Наприклад, якщо говорити про освіту, то вже кілька років тому під час форсайту безпеки можна було спрогнозувати багато 3 тих загроз, з якими люди зіткнулися зараз. До таких можна віднести необхідність цифровізації та онлайнізації навчання, важливість якої усвідомили у зв'язку 3 карантином та ізоляцією населення через загрозу світової пандемії.

У межах адміністративно-правових засад, під час форсайту безпеки не може i не повинно ставитися завдання точно передбачити всі можливі загрози або точно їх описати. Такий абсолютистський підхід є тупиковим. Цілком зрозуміло, що більшість загроз так чи інакше дійсно може виникнути. Звичайно, адміністративноправові засади повинні бути максимально гнучкими, тому що загрози можуть виникати трохи не в тому вигляді, в якому були б описані під час Форсайту безпеки. Проте вже точно буде відомо, що вони будуть собою представляти, а завдяки прийнятим засадам буде реально перебудувати стратегію захисту та модель безпеки організації для ефективної відсічі цим загрозам та ймовірним агресорам.

Іншим цікавим прикладом може служити поява спеціальності посередника, який може забезпечити безпеку при здійсненні угод немайнового та міжкультурного характеру. Його можна визначити адміністративно-правовими засадами як людину, що працює в штаті служб безпеки та буде, замість основних сторін, які знаходяться на самоізоляції, присутня при підписанні міжнародних договорів для консультування в питаннях безпеки, пов'язаних 3 культурними особливостями учасників. Відомо, що досі така спеціалізація всередині корпорацій відсутня, але вже з'явилися окремі компанії, які саме цим i займаються. Тобто така задача в основному пішла на аутсорс, або цим займаються фахівці з безпеки, яких, коли необхідно, залучають до окремих переговорів як доповнення до звичайної роботи.

\section{Висновки і перспективи подальших досліджень}

Автор поставив перед собою завдання донести до широкого загалу наукової спільноти новий погляд на сучасну методику реконструкції моделі безпеки організації, яка базується на активному застосуванні форсайту безпеки.

Ефективне застосування інструменту, який на заході називають форсайтом безпеки, дозволить уявити світ, яким він буде через десять років, спрогнозувати ризики та позитивний потенціал подій, ймовірність яких сьогодні може видаватися надзвичайно малою. Наглядність варіативності майбутнього, яку демонструє повноцінний форсайт, дає змогу виокремити як вкрай небажані, так і найбільш бажані варіанти розвитку подій. Але головною перевагою форсайту, як інструменту безпеки, є можливість усвідомити, що саме варто робити вже зараз, щоб майбутній світ відповідав найбільш оптимістичному прогнозу. 
Особливості форсайту, як інструменту безпеки, проаналізовано на прикладі карантинних заходів, спрямованих на протидію пандемії COVID-19. Уже сьогодні можна спостерігати появу нової професії - безпекового посередника - як особи, що працює в штаті служб безпеки або окремої фірми та буде, замість основних сторін, які знаходяться на самоізоляції, присутня при підписанні міжнародних договорів для консультування в питаннях безпеки, пов'язаних з культурними особливостями учасників

Наголошено на існуванні в сучасній безпековій практиці двох форматів форсайту безпеки, які відрізняються масштабністю. При цьому більш масштабний формат, який передбачає залучення великої кількості фахівців, проведення циклу форсайт-сесій, потребує належного адміністративно-правового регулювання, що обумовлюе один 3 вагомих напрямів подальших досліджень у цій сфері.

\section{Аітература}

1. Road map Report Concerning the Use of Nanomaterials in the Automotive Sector (2006) // Nanomaterial Roadmap 2015. URL: $\quad$ http://www.aimme.es/archivosbd/ observatorio oportunidades/nano-roadmap automotive-industry.pdf

2. Серегина С. Ф., Барышев И. А. Закономерно ли появление форсайта? // Форсайт. 2008. № 2(6). Т. 2 № 2. С. 4-12.

3. Аисенко С. Особливий погляд на інформаційну безпеку. «Видавниитво Аюдмила», Київ. 2020. 405с.

4. Phaal R., Muller G. (2009) An Architectural Framework for Road mapping: Toward Visual Strategy // Technological Force casting and Social Change. № 76. P. 39-49.

5. Аисенко С. Адміністративно-правові засади інформаційної безпеки підприємництва. «Видавництво Аюдмила», Київ. 2019. 385c.

6. Н. Талеб. Чорний лебідь: Про (не) ймовірне в реальному житті. Київ : Наш Формат, 2017. 392 с.

7. Clayton A. (2009) Postroenie dorozhnykh kart dlya razvivayushchikhsya stran [Roadmapping in Developing Countries]. Foresight-Russia, vol. 3, no 1, pp. 48-57 (in Russian).
8. Clayton, A. Technology Roadmapping for Developing Countries. Vienna, UNIDO Publ., 2005.

\section{FUTURE VIEW ON SECURITY ORGANIZATION: SEGURITY FORESIGHT AND HOW TO USE IT}

The article is devoted to a new look at the modern method of reconstruction of the security model of the organization, which is based on the active use of security foresight. The genesis of security foresight formation and peculiarities of its application in modern conditions are considered.

Security foresight is seen as a tool for forecasting and shaping the future security model of the organization, which allows in a short period of time to obtain fairly accurate forecasts of possible risks and shortcomings in the development of the organization in the long run.

It was stated that security foresight allows not only to predict probable threats and positive consequences, but also to identify different future scenarios. It is determined that the main advantage of foresight as a security tool is the ability to realize what exactly should be done now to make the future world meet the most optimistic forecast.

Emphasis is placed on the existence in modern security practice of two formats of security foresight, which differ in scale. A smaller scale format, or "local foresight", involves a separate foresight session to predict a phenomenon. A larger format, which involves a large number of specialists, conducting a series of foresight sessions, requires proper administrative and legal regulation, which determines one of the important areas of further research in this area.

The author analyzes the peculiarities of the use of foresight on the example of quarantine measures aimed at counteracting the COVID-19 pandemic and predicting the threats posed by both the epidemic itself and measures to combat it.

Particular attention is paid to the description of a new profession - "security mediator", as a person working in the security services, or a separate firm and will, instead of the main parties in self-isolation, be present 


\section{Кримінальне право, кримінальний процес та криміналістика}

\section{АНОТАЦІЯ}

Статтю присвячено новому погляду на сучасну методику реконструкиій моделі безпеки організачї, яка базується на активному застосуванні борсайту безпеки. Розглянуто генезу становлення форсайту безпеки та особливості його застосування в сучасних умовах.

Форсайт безпеки розглядається як інструмент для прогнозування $i$ бормування майбутнъої моделі безпеки організащиї, що дозволяє за короткий період часу отримати доволі точні прогнози про можливі ризики та недоліки в розвитку організаий у довготривалій перспективі.

Констатовано, що форсайт безпеки дозволяе не просто спрогнозувати ймовірні загрози та позитивні наслідки, але й визначити різні сценарї майбутнъого. Визначено, що головною перевагою борсайту, як інструменту безпеки, $\epsilon$ можливість усвідомити, що саме варто робити вже зараз, щоб майбутній світ відповідав найбільш оптимістичному прогнозу.

Наголошено на існуванні в сучасній безпековій практииі двох борматів борсайту безпеки, які відрізняються масштабністю. Менш масштабний бормат, або «локальний форсайт», передбачає проведення окремої борсайтсесї для прогнозування того чи іншого явища. Більи масштабний бормат, який передбачає залучення великої кількості бахівців, проведення изиклу борсайт-сесій, потребує належного адміністративно-правового регулювання, що обумовлює один з вагомих напрямів подальших досліджень у иій сфорі.

Автор аналізує особливості застосування форсайту на прикладі карантинних заходів, спрямованих на протидію пандемї COVID-19 та прогнозування тих загроз, які несе за собою як сама епідемія, так $і$ заходи протидіӥ їи.

Окрему увагу присвячено опису нової професій - «безпекового посередника», як особи, яка працюе в штаті служб безпеки, або окремої організаиї та буде, замість основних сторін, які знаходяться на самоізоляиій, присутня при підписанні міжнародних договорів для консультування з питань безпеки, пов'язаних, серед іншого, з культурними особливостями учасників.

Ключові слова: Форсайт; борсайт безпеки; прогнозування загроз; майбутнє; експертна діяльність; адміністративно-правове регулювання; COVID-19; безпековий посередник. at the signing of international agreements for security advice. related to the cultural characteristics of the participants.

Keywords: foresight; safety foresight; threat forecasting; future; expert activity; administrative and legal regulation; COVID-19; security broker. 


\title{
ДОМАШНЕ НАСИЛЬСТВО: ЩОДО ЗМІСТОВНОГО НАПОВНЕННЯ ТЕРМIHА
}

\author{
МАЛИНОВСЬКА Тетяна Миколаївна - кандидат юридичних наук, доценТ, \\ провідний науковий співробітник науково-дослідної лабораторії 3 проблем \\ протидії злочинності Харківського національного університету внутрішніх справ \\ https://orcid.org/0000-0002-7713-7617 \\ УДК 343.9:343.226(477) \\ DOI 10.32782/LAW.2020.3.14
}

\begin{abstract}
Рассмотрена правовая природа термина «насилие»как асочиальное явление. Проанализированъ понятия «насилие в семье» $u$ «омашнее насилие»как в международно-правовых актах, так и на уровне национального законодательства. Акцентировано внимание на определении понятия «семья» $и$ «лень семъи». На основе мнений и взглядов ученъх, исследовавших указанную проблематику, предложено собственное определение термина «домашнее насилие»

Ключевъе слова: домашнее насилие, насилие в семье, семья, илен семьи, насилие по половому признаку, супруги.
\end{abstract}

\section{Вступ}

Проблема домашнього насильства надзвичайно важлива передусім тому, що сім'я є основною суспільства і має перебувати під особливим захистом держави. Насильство і жорстокість в сім’ї не лише руйнують гармонію і злагоду в ній, а й виступають однією з передумов злочинності в суспільстві загалом.

Держава - основний суб'єкт протидії насильству, оскільки органи державної влади повинні сприяти створенню обстановки неприйняття насильства, вживаючи необхідних заходів та створюючи систему захисту жертв, покарання кривдників і запобігання насильству.

Незважаючи на сучасне нормативноправове забезпечення у сфері протидії та захисту прав і інтересів осіб, що постраждали від домашнього насильства, а також на значну кількість наукових праць, присвячених різним аспектам у цій сфері, проблема домашнього насильства не втрачає своєї актуальності. I, у першу чергу, потребує теоретичного осмислення й уточнення та належного обгрунтування категоріального апарату з означеної тематики, зокрема 3 огляду на неоднозначність термінів «домашне насильство» та «насильство в сім' $\dddot{1} »$.

У науковій статті розглянуто змістовну природу терміна «насильство» як асоціального явища. Проаналізовані поняття «насильство в сім’і» та «домашне насильство» як в міжнародно-правових актах, так і на рівні національного законодавства. Акцентовано увагу на визначенні поняття «сім'я» та «члени сім'ї». На основі думок та поглядів учених, які досліджували означену проблематику запропоновано власне визначення терміна «домашнє насилля».

\section{Постановка проблеми}

Останніми роками в Україні приділяється велика увага проблемам запобіганню та протидії домашньому насильству, яке призводить не тільки до втрати найдорожчого для людини - життя та здоров'я, а також завдає великої соціальної та моральної шкоди суспільству.

Сучасний підхід до проблеми домашнього насильства включає, з одного боку, укоріненість цієї проблеми в суспільній свідомості як міжособистісної, а 3 іншої - виходить з обов'язків держави гарантувати права лю- 


\section{Кримінальне право, кримінальний процес та криміналістика}

дини в усіх сферах життя, у тому числі й у сфері сімейних відносин.

Причини насильства, перш за все, пов'язані $з$ економічною ситуацією, падінням моралі та байдужим ставленням до насильства. Насильство найчастіше вважається приватною справою, і багато жертв не повідомляють про такі випадки до правоохоронних органів. Неповідомлення про факти насильства, у свою чергу, не дозволяє провести розслідування, притягти до відповідальності та покарати кривдника так, як цього вимагає закон. Більшість випадків не доходять до суду, а коли доходять, то злочинці, як правило, отримують мінімальне покарання [1, с.13]. Вдосконалення правової оцінки домашнього насильства багато в чому залежить від усвідомлення громадськістю та самими потерпілими того, що насильство є протиправним явищем, а часто і злочином.

Насильство як асоціальне явище не тільки формує трагічні обставини для багатьох людей, але й створює криміногенні ситуації, які передують кримінальним злочинам проти безпеки, здоров'я і життя людини, що в цілому руйнує фундамент стабільності суспільства.

Для підвищення запобігання домашньому насильству потребує окремого дослідження природа терміна «насильства». Як зауважує А. Блага, «...при розробці основних теоретичних засад запобігання насильству в цілому, та насильству в сім'ї, зокрема, слід виходити з багатовимірного пояснення цього феномену, у якому немає провідної ролі якогось одного чинника чи складника» [2, с. 250].

\section{Стан дослідження}

Проблеми попередження домашнього насильства у значній мірі досліджували вчені О. Бандурка, А. Блага, В. Вітвицька,О. Джужа, ᄉ. Завадська, ᄉ. Кормич,入. Крижна, Н. Аавриненко, I. Аавринчук, К. Аевченко, $\lambda$. Аеонтьєва, $\lambda$. Аевицький О. Матвієнко, Т. Мельник, Т. Мінка та інші, однак попри широке коло наукових досліджень у сфері захисту прав людини від насильницьких злочинів, питання термінів «насильство в сім'ї» та "домашне насилля» залишається дискусійним.
Метою та завданням статті розроблення власного визначення терміна "домашнє насилля». Завданням є аналіз та порівняння термінів «насильство в сім'і» та «домашнього насильства» в нормативно-правовому визначенні.

Наукова новизна дослідження полягає в обгрунтуванні власного бачення змістовного наповнення терміна «домашнє насилля» на основі думок та поглядів учених, які досліджували означену проблематику.

\section{Виклад основного матеріалу}

Поняття «насильство в сім'ї» «домашне насильство» використовуються в міжнародно-правових актах зобов'язального й рекомендаційного характеру, що існують як на рівні $\mathrm{OOH}$, так і Ради Європи та Европейського Союзу. Серед них необхідно визначити Загальну декларацію прав людини 1948 р. [3], яка вважається головним документом у галузі захисту прав людини. Декларація проголосила принципи юридичної рівності, а також заборону дискримінації за будьякими ознаками, у т.ч. за ознаками статі.У Декларації про ліквідацію дискримінації щодо жінок 1967 р., яка пізніше, у 1979 р., була замінена однойменною Конвенцією, зазначається, що мають бути вжиті всі належні заходи з метою підготовки громадської думки на напрямки національних прагнень до викоренення забобонів, звичаїв та всіх інших проявів, заснованих на ідеї неповноцінності жінок [4]. Декларація про викорінювання насильства щодо жінок 1993р., де визнала насильством до жінок будь який акт насильства, здійснений на підставі статевої ознаки, який спричиняє або може заподіяти фізичний, статевий чи психологічний збиток або страждання жінкам, а також загрози вчинення таких актів, примус або довільне позбавлення свободи, чи то в суспільному, чи в особистому житті. Також у Декларації зазначено, що насильство до жінок охоплює випадки фізичного, статевого та психологічного насильства, яке має місце в сім’ї [5].

Комітет ООН з ліквідації дискримінації щодо жінок під час 11 сесії прийняв Загальну рекомендацію № 19 «Насильство щодо 
жінок», у якій чітко визначив, що «насильство стосовно жінок - одна з форм дискримінації, що серйозно обмежує можливості жінок щодо користування правами та свободами на основі рівності 3 чоловіками». Насильство в сім’ї розглядається як прояв насильства щодо жінок, оскільки непропорційно впливає на жінок, і саме жінки в переважній більшості страждають від цього порушення прав людини [6, с.11].

Організація Об'єднаних Націй визначає, що насильницькі дії в сім'ї представляють усі насильницькі дії фізичного, психологічного i сексуального характеру відносно жінок, здійснені на підставі статевої ознаки особою або особами, які пов'язані з ними родинними і близькими стосунками, від словесних образ і погроз до важких фізичних побоїв, викрадання, загрози каліцтвами, залякування, примус, переслідування, словесні образи, насильницьке або незаконне вторгнення в житло, підпал, знищення власності, сексуальне насильство, згвалтування в шлюбі, насильство, пов'язане з посагом або викупом нареченої, каліцтва геніталій, насильство, пов'язане $з$ експлуатацією через проституцію, насильство відносно хатніх робітниць та спроби здійснити такі акти повинні розглядатися як «насильство в сім'і» [6, с.12].

Саме Модельне законодавство ООН покладено в основу Закону України «Про попередження насильства в сім'і», який був ухвалений Верховною Радою України 15.11.2001 р. (втрата чинності 07.01.2018). Цей Закон гарантував охорону прав членів сім’ї при здійсненні заходів з попередження насильства в сім’ї та визначав організаційноправові основи попередження насильства в сім’і; підстави для вжиття заходів 3 попередження насильства в сім'ї; повноваження органів та установ, на які покладається здійснення заходів 3 попередження насильства в сім’ї, і джерела їх фінансування; спеціальні заходи попередження насильства в сім'ї; відповідальність за вчинення насильства в сім'ї тощо [7, с.36]. У Законі було надано визначення насильству в сім'ї як будь-які умисні дії фізичного, сексуального, психологічного чи економічного спрямування одного члена сім’ї по відношенню до іншого члена сім'ї, якщо ці дії порушують конституційні права і свободи члена сім’ї як людини та громадянина і наносять йому моральну шкоду, шкоду його фізичному чи психічному здоров'ю.

Слід зауважити, що при встановленні змістовного наповнення поняття «насильство в сім’ї» концептуально важливими є поняття «сім'я», «члени сім'і».

Визначення сім'ї надається у ст. 3 Сімейного кодексу України, де сказано: «Сім ю складають особи, які спільно проживають, пов язані спільним побутом, мають взаємні права та обов 'язки. Подружжя вважається сім єю і тоді, коли дружина та чоловік у зв `язку з навчанням, роботою, лікуванням, необхідністю догляду за батьками, дітьми та $з$ інших поважних причин не проживають спільно. Дитина належить до сім ї своїх батьків і тоді, коли спільно 3 ними не проживає. Сім я створюється на підставі шлюбу, кровного споріднення, усиновлення, а також на інших підставах, не заборонених законом і таких, що не суперечать моральним засадам суспільства» [8]. I. Тімуш при дослідженні в правовому та соціальному аспекті терміна «сім'я» розглядає його у двох напрямках. Перший напрям правових досліджень полягає у тому, що сім'я не розглядається в юридичному аспекті, «оскільки суб'єктом сімейного права $\epsilon$ не сім'я, а конкретні особи (подружжя, діти, батьки)». Соціальна складова підкреслюється широтою критеріїв, що характеризують сім'ю та відмінністю умов існування сімей. Другий напрям правових досліджень полягає у тому, що соціальні відносини регулює саме право, незважаючи на те, що сім'я є соціальною категорією. Тому сімейні відносини набувають правового змісту та стають правовідносинами, що надає сім’’̈ правового статусу.

I. Тімуш зазначає, що сім'ю у правовому розумінні доцільно розглядати як юридичний зв'язок між фізичними особами. Застосування поняття юридичний зв'язок чітко підкреслює те змістове навантаження, яке вказує на сім'ю як правову категорію та чітко відмежовує юридичне визначення сім’ї від соціологічного. Юридичний зв’язок є нічим іншим як правовідносинами, що виникають між членами сім’ї на визначених законом підставах. Такий зв'язок полягає у наділенні фізичних осіб, які складають сім'ю, 


\section{Кримінальне право, кримінальний процес та криміналістика}

взаємними правами та обов'язками, якими пов’ язує (зв'язує) їх закон [9, с.111].

Отже, членами сім’і можуть бути: подружжя; батьки (мати, батько) й дитина (діти); усиновителі (усиновитель) і усиновлений (удочерена); дід (бабуся) і онук (онука); вітчим (мачуха) і пасинок (падчерка); брати і сестри; фактичні вихователі і вихованці. Членами сім'ї можуть бути визнані також i інші особи, які є родичами і разом проживають. Підкреслимо, що сини і доньки належать до сім’ї своїх батьків і тоді, коли спільно з ними не проживають. Відповідно до Закону України «Про попередження насильства в сім'ї» визначено, що члени сім’ї - це особи, які перебувають у шлюбі; проживають однією сім'єю, але не перебувають у шлюбі між собою; їхні діти; особи, які перебувають під опікою чи піклуванням; є родичами прямої або непрямої лінії споріднення за умови спільного проживання [10, с. 149].

Тлумачення поняття «член сім'і» дається в П. 6 Рішення Конституційного Суду України від 03.06.1999 р., №5-рп/99, у якому міститься роз'яснення з цього приводу. Конституційний Суд України виходить 3 об'єктивної відмінності його змісту залежно від галузі законодавства (п.6). Таким чином, на думку Конституційного Суду, визначити єдине поняття «член сім’і», яке б мало застосовуватися в праві, неможливо, бо кожна галузь права тлумачить це поняття по-своєму, підкреслюючи ті чи інші ознаки сім'ї, які набувають певного значення для інших відносин. На думку I.В. Жилінкової, в основу визначення сім’ї повинні бути покладені лише головні ознаки, через які сім'я розглядалась б саме як юридичний феномен, надає таке визначення «в юридичному визначенні сім'я - це об'єднання осіб, пов'язаних між собою спільністю життя та взаємними правами і обов'язками, що виникають за підстав, передбачених у законі» $[11$, с. 51]. Дослідниця визначає, що членом сім'ї необхідно вважати як найближчу особу, так і іншу людину, з якою разом живуть або ведуть господарство. Разом з тим, Сімейний кодекс України не включає до членів сім'ї колишнє подружжя, навіть за умови спільного проживання.
Термін «домашнє насилля» вживається в Европейській Конвенції про запобігання та боротьбу з насильством стосовно жінок та домашнім насильством, що була відкрита для підписання 11 квітня 2011 року та підписана від імені України, під домашнім насиллям в якій розуміються всі акти фізичного, сексуального, психологічного чи економічного насильства, що здійснюеться у сім'ї або на побутовому рівні або між колишнім чи теперішнім подружжям, партнерами, незважаючи на те, чи проживає правопорушник із жертвою або окремо від неї [12].

Постановою Кабінету Міністрів України «Про внесення змін до постанови Кабінету Міністрів України від 5.09.2007 № 1087 «Про консультативно-дорадчі органи 3 питань сім’і, гендерної рівності, демографічного розвитку, запобігання насильству в сім'ї та протидії торгівлі людьми», термін «насильство в сім'ї було замінено на «домашне насильство». На законодавчому рівні термін був введений Верховною Радою України 07.12.2017 р. при прийнятті Закону України № 2229-VIII «Про запобігання та протидію домашньому насильству», який спрямований на реформування вітчизняної системи запобігання та протидії домашньому насильству та насильству за ознакою статі. Цим Законом домашне насильство визнається як діяння (дії або бездіяльність) фізичного, сексуального, психологічного або економічного насильства, що вчиняються в сім'ї чи в межах місця проживання або між родичами, або між колишнім чи теперішнім подружжям, або між іншими особами, які спільно проживають (проживали) однією сім'єю, але не перебувають (не перебували) у родинних відносинах чи у шлюбі між собою, незалежно від місця, що й постраждала особа, а також погрози вчинення таких діянь [13].

При цьому діяння визнається насильством лише тоді, коли воно порушує вимоги чинного законодавства і призводить чи може призводити до порушення конституційних прав і свобод члена сім'ї. Домашнє насильство може мати форму як активних дій (нанесення побоїв, знищення майна тощо), так і бездіяльності, тобто пасивної поведінки особи, коли вона не вчиняє дій, 
які могла та повинна була вчинити, щоб запобігти настанню шкідливих наслідків (наприклад, ненадання допомоги члену сім'ї, який перебуває у небезпечному для життя становищі).

Зауважимо, що при визначенні домашнього насильства як соціального явища зазвичай вживаються такі терміни: насильство в сім'ї, сімейне насильство, насильство за ознакою статі, домашне насильство, внутрішньосімейне насильство як еквіваленті, а в ряді випадків поєднуються з поняттям побутового насильства. Саме тому й виникає питання про смислову змістовність і співвідношення зазначених термінів.

На перший погляд, дійсно принципових відмінностей між змістовним навантаженням цих термінів не існує. Однак більш детальний аналіз дозволяє виділити ряд відмінностей. Так, С. Максімов і В. Ревін визначали «побутове насильство» як злочини «на грунті конкретно-особистісних, невиробничих відносин, конфліктів, мотивованих неприязню, заздрістю, ревнощами або хуліганськими діями винного, пов'язаного 3 потерпілим сімейним, або сусідським спілкуванням» [14, с. 27]. 3 цього ствердження, зрозуміло, що взаємозв'язок «злочинецьжертва» тут не обов'язково передбачає наявність сімейних відносин. Більше того, ми 6 доповнили це визначення тим, що для оцінки злочину як побутового не потрібно тривалого і стійкого міжособистісного спілкування, як це передбачається при кваліфікуванні домашнього насильства.

Як визначає Ф. Меліков, ключовим словом терміну «домашнє насильство» $є$ слово «домашнє», що відноситься до будинку, тобто його етимологічна суть означає «житло і людей, що живуть у ньому», це можуть бути як члени сім’ї, так і інші особи, стосунки, які склалися у будинку, що означає, територіальна ознака цього поняття $є$ визначальною [15, c. 29-30].

На погляд автора цієї статті, визначальним словом терміна "домашнє насилля» 6 не обмежене місце здійснення насильницьких дій (будівля чи інша домашня територія), а суб'єкти таких посягань. У цьому випадку «домашнє» - прикметник, який стосується дому, а в цьому аспекті предметом є відно- сини і юридичний статус осіб, які повніше описуються поняттям сім'ї. Враховуючи, що на одній території можуть проживати декілька сімей i, наприклад, може бути скоєний насильницький злочин між сусідами, але такий злочин не буде розглянуто як домашнє насилля. О. Гумін визначає, що термін «домашне насильство» дещо нечіткий і не вказує учасників такого насильства, обмежуючи насильницький акт домашньою територією. Поняття «насильство в сім'ї» та «сімейне насильство», що приймаються як синоніми, є розширеними, що містять усі аспекти агресивного примусового впливу, що завдає різні збитки члену сім'ї, і поширені в міжнародних актах [16, с. 496].

Т. Мінка визначає, що для кваліфікації ст. 126-1 Кримінального Кодексу України не має значення, чи проживає правопорушник у момент вчинення діяння в тому самому місці, що й потерпілий. Дуже часто домашне насилля може відбуватися й після розриву сімейних відносин чи інших стосунків, тому спільне проживання жертви і правопорушника не вимагається $[17$, с.100].

Саме тому імплементація в масив кримінального закону України поняття «домашнього насильства» як окремого виду кримінального правопорушення викликає чимало наукових дискусій. Насамперед, це стосується дублювання одного і того ж поняття «домашне насильство» у дещо відмінних інтерпретаціях у положеннях Закону України «Про запобігання та протидію домашньому насильству» та, зокрема, у КК України. Такий підхід законодавця, з одного боку, видається виправданим, адже має на меті підкреслити особливості домашнього насильства саме як кримінального правопорушення. Хоча, з іншого боку, наявність двох різних законодавчих дефініцій щодо одного й того ж поняття видається таким, що, поперше, суперечить правилам законодавчої техніки; по-друге, певною мірою ускладнює практику застосування відповідних положень КК України; по-третє, не сприяє чіткості ведення статистичного обліку задля кількісної оцінки вчинених кримінальних правопорушень, пов'язаних з домашнім насильством, що, зрештою, не сприяє адекват- 


\section{Кримінальне право, кримінальний процес та криміналістика}

ному плануванню заходів у такому напрямі протидії.

Підводячи підсумок, слід вказати, що зміст домашнього насильства опосередковується через тривалі відносини між близькими людьми, пов'язаними спільним побутом чи родинними зв'язками.

На відміну від злочину, здійсненого незнайомою людиною, домашне насильство виходить від чоловіка або партнера, дружини, колишнього чоловіка, колишньої дружини, батьків, дітей, інших родичів.

3 урахуванням вищевикладеного, можна запропонувати наступне визначення домашне насильство - це акти умисного систематичного вчинення протиправного фізичного, психологічного, сексуального, економічного впливу на близьких людей, які здійснюються проти їх волі з метою надбання влади і контролю над ними, що призводить до різного роду страждань, розладів здоров'я, емоційної залежності чи погіршення якості життя потерпілої особи.

\section{Аітература}

1. Конвенція Ради Европи про запобігання насильству стосовно жінок і домашньому насильству та боротьбу із цими явищами (Стамбульська конвенція) Довідник для членів парламенту, 2013. - 108 с. URL: https://rm.coe.int/1680096e45 (дата звернення: 07.09.2020).

2. Блага А.Б. Дослідження соціальної природи насильства - теоретичне підгрунтя для кримінологічного аналізу насильства в сім’ї Порівняльно-аналітичне право № 3-2 $2013247-250$ c.

3. Загальна декларація прав людини від 10 рудня 1948 року // Офіційний вісник України. - 2008. - № 93. - Ст.3103

4. Комітет економічних, соціальних і культурних прав : Документ ООН Е/С.12/1995/15 від 8 груд. 1995 р. - П. 25.

5. Декларация об искоренении насилия в отношении женщин: Міжнародний документ від 20 груд. 1993 р. - URL: http:// zakon3.rada.gov.ua/laws/show/995_506. (дата звернення 10.08.2020)

6. Моніторинг стану виконання законодавства України щодо протидії насильству в сім'ї. 2001-2011 роки / Кол. авт.:-
O.M. Бандурка, О.Ф. Бондаренко,В.О. Брижик, та ін.; заг. ред. О.М. Бандурки,К.Б. Аевченко; вступ. слово О.О. Зарубінського . - Х. : Видавництво «Права людини», 2011. - 240 c.

7. Ткаленко О. М. Нормативно-правове забезпечення попередження насильства в сім’ї в Україні: стан та перспективи розвитку Південноукраїнський правничий часопис № 3- 2014 35-38с.

8. Сімейний кодекс України : Закон України від 10.01.2002 № 2947-III. Відомості Верховної Ради України. 2002. № 21-22. Ciт. 135.

9. Тімуш I.C. Визначення сім’ї у юридичній науці. Юридичний вісник. Повітряне і космічне право № 2 (47) Київ. 2018. 109$115 \mathrm{c}$.

10. Череваш О. М. Адміністративноправова характеристика насильства в сім’ї . Право і суспільство № 6 .- 2011. 147-151с.

11. Насильство в сім'ї ( кримінологічний аналіз і запобігання): монографія /А.Б. Блага. - Х. : ФО-П Макаренко, 2014. 360c.

12. Конвенція Ради Европи про запобігання насильству стосовно жінок i домашньому насильству та боротьбу із цими явищами: Міжнародний документ від 11 травн. 2011 URL: https://ips.ligazakon.net/ document/view/MU11251 (дата звернення 10.08.2020)

13. Про запобігання та протидію домашньому насильству: Закон України від 07.12.2017 № 2229-VIII. URL: http://zakon3. rada.gov.ua/laws/show/2229-19 (дата звернення: 16.06.2020).

14. Максимов С.В., Ревин В.П. Насильственные преступления в сфере семейнобытовых отношений и проблемы их профилактики: учебное пособие. М., 1993. - 56 с

15. Меликов Ф.А. Уголовно-правовые и криминалогические меры противодействию насилия в семье дисерт. канд. юрид. наук 12.00.08. М. 2017 -181C.

16. Гумін О.М. Кримінологічна характеристика насильства у сім'ї щодо неповнолітніх 2016.- C. 492-499 UKR: http://science. lpnu.ua/sites/default/files/journal-paper/2017/ aug/5774/vnulpurn201685074.pdf (дата звернення 03.09.2020) 


\section{АНОТАЦІЯ}

Домашнє насильство є однією з розповсюджених борм порушення прав людини. У більшості випадків протиправні дї проти когось iз иленів родини супроводжуються актами агресї, приниження та жорстокої поведінки. Подібні дї з боку насильника приводять до негативного фбізичного, психічного та сочіального стану здоров'я постраждалої особи чи кількох осіб, иленів иієї родини. Як правило, найбільше страждають від домашнього насильства жін$\kappa и$, діти та люди похилого віку.

Держава - основний суб'єкт протидї насильству, оскільки органи державної влади повинні сприяти створенню обстановки неприйняття насильства, вживаючи необхідних заходів та створюючи систему захисту жертв, покарання кривдників $i$ запобігання насильcmsy.

Незважаючи на існуюче нормативно-правове забезпечення в сбері протидї та захисту прав $і$ інтересів осіб, що постраждали від домашнього насильства, а також на широку кількість наукових праць, присвячених різним аспектам в изй сфері, проблема домашнъого насильства не втрачає своєї актуальності. I, у першу чергу, потребує теоретичного осмислення й уточнення та належного обгрунтування категоріальний апарат з означеної тематики, зокрема з огляду на неоднозначність термінів «домашнє насильство» та «насильство в сім'

Метою статті є проведення порівняльного дослідження понять «насильство в сім'і» та «домашне насильство», яке використовується як в міжнародно-правових актах, так $і$ на рівні національного законодавства. Здійснити аналіз різних точок зору вчених щодо змістовного визначення понять «насильство в сім'і» та «домашне насильство». На основі поглядів вчених, які досліджували означену проблематику, запропоновати власне визначення терміну «домашне насилля».

Ключові слова: домашне насилля, насильство в сім'і, сім'я, илен сім'і, насильство за ознакою статті, подружжя.

17. Мінка Т. Розмежування адміністративної та кримінальної відповідальності за вчинення домашнього насильства Нац. юрид. журнал теорія та практика 2019 с. 98-101

\section{Malynovska Tatyana \\ Domestic Violence: Regarding the Content of the Term}

Domestic violence is one of the most common forms of human rights violations. Illegal actions against a family member are in most cases accompanied by acts of aggression, humiliation and abuse. Such actions by the abuser lead to a negative physical, mental and social state of health of the victim or several members of this family. As a rule, women, children and the elderly suffer the most from domestic violence.

The state is the main subject of combating the violence, since the public authorities should assist in creating the environment of nonacceptance of violence, taking the necessary measures and creating the system of protection of victims, punishment of perpetrators and prevention of violence.

Despite the existing regulatory provision in the field of combating and protecting the rights and interests of victims of domestic violence, as well as a wide range of scientific papers focused on various aspects in this area, the problem of domestic violence remains relevant. And, first of all, the categorical apparatus on this topic needs theoretical comprehension, clarification and proper substantiation, in particular, considering the ambiguity of the terms of "domestic violence" and "violence within the family".

The purpose of the article is to conduct a comparative study of the concepts of "domestic violence" and "violence within the family", which are both used in international legal acts and at the level of national legislation; to analyze different points of view of scholars in regard to the content of the notions of "domestic violence" and "violence within the family". Based on the views of scholars who studied those issues, the author has suggested own definition of the term of "domestic violence".

Keywords: domestic violence, domestic violence, family, family member, gender-based violence, spouses. 


\title{
АУДИТ ЯК НЕВІД'СМНА СКЛАДОВА КРИМІНАЛІСТИЧНОЇ МЕТОДИКИ РОЗСЛІДУВАННЯ ЗЛОЧИНІВ У СФЕРІ ГОСПОДАРСЬКОЇ ДІЯЛЬНОСТІ
}

\author{
ОСМОЛЯН Віталій Анатолійович - кандидат юридичних наук, старший \\ викладач кафедри права, Хмельницький кооперативний торговельно-економічний \\ інститут
}

УДК 343.98.06

DOI 10.32782/LAW.2020.3.15

Излагаются правовъе основъ и перспективъ развития криминалистики в свете новых криминальных угроз при стремительном развитии совершения преступлений в сбере хозяйственной деятельности. Рассмотрено процессуально-правовъе и экспертно-криминалистические вопросъ по возможности въявления, Фиксачии и собирании следовой картинъ и бормировании доказательной базъ в совершении преступлений в сбере хозяйственной деятельности, а также обоснована необходимость эфбективного содействия работников следственньх органов, суда и пробильных специалистов Государственной аудиторской службы, а также государственной контрольно-ревизионной службъ Украинъ для качественного и оббективного въполнения заданий уголовного производства и улучшение инновачионной политики Украинъ. Приведенъ конкретнъе примерь вопросов, которье ставились на рассмотрение пробильных специалистов в области проведения аудита хозяйственной деятельности субъекта правоотношений, что имело место на практике. Сделанъ въгводъ и предоставленъ рекомендащии по согласованному использованию норм действующего законодательства в практической деятельности специиалистааудитора и следователя. Обращено внимание на необходимости дальнейшего научного сотрудничества ученъгх, спеччиалистов в области материального и процессуального права.

Ключевъие слова: криминалистика, преступление, метод, аудит, хозяйственная деятельность, информачия, правоохрани- тельные органъ, досудебное расследование, уголовное производство, экспертиза, эксперт, специалист.

\section{Постановка проблеми}

Злочини у сфері господарської діяльності є специфічним явищем злочинної діяльності, яке постійно розвивається $з$ неминучим розвитком та удосконаленням технічного прогресу, а також нерозривно поєднане із економічною ситуацією та господарською діяльністю країни в цілому. Саме ця новизна та специфічність, неухильний та постійний розвиток вказаного виду злочину вимагають від судових та правоохоронних органів, криміналістів удосконалення вже сучасних, розроблення та застосування нових криміналістичних засобів та методів у їх виявленні та фіксації для подальшого невід'ємного використання у проведенні ефективного розслідування, встановленні та притягненні винних осіб до відповідальності.

Це покладає особливу відповідальність на правоохоронні органи щодо проведення якісного та легітимного досудового розслідування у кримінальних провадженнях зазначеної категорії, повного та неупередженого збору доказової бази, що не уявляється можливим без суворого дотримання процедури законності. У цьому і полягає актуальність проблеми.

Аналіз останніх досліджень та публікацій

Проведений аналіз [1-7] показав, що вчені неодноразово досліджували діяльність 
правоохоронних органів по збиранні доказової бази, проведенні криміналістичних дій у цілому та іï окремі аспекти зокрема. Проте розгляд процесуально-правових та експертно- криміналістичних питань щодо нових можливостей виявлення, фіксації та збирання слідової картини та формування в подальшому доказової бази вчинення злочинів у сфері господарської діяльності вимагає детального дослідження та аналізу.

Мета статті - на підставі проведеного теоретичного аналізу та власного практичного досвіду розглянути процесуально-правові та експертно-криміналістичні питання нових можливостей у виявленні, фіксації та збиранні слідової картини та формуванні доказової бази вчинення злочинів у сфері господарської діяльності, а також обгрунтувати необхідність ефективної співпраці працівників слідчих органів, прокуратури, суду та Державної аудиторської служби, а також державної контрольно-ревізійної служби України для якісного та об'єктивного виконання завдань кримінального провадження та покращення інноваційної політики України взагалі.

\section{Виклад основного матеріалу}

Будівництво в Україні правової держави та європейсько-демократичного суспільства передбачає якісне зменшення порушень правопорядку, суттєве зменшення рівня злочинності, по можливості зменшення причин, що ії породжують.

Методика розслідування окремих видів злочинів як невід'ємний розділ сучасної системи криміналістики складається з системи наукових положень та розроблених на їх основі рекомендацій щодо процесу розкриття та розслідування злочинів.

3 урахуванням специфіки вчинення різного виду злочинів, вичерпний перелік яких надано законодавцем в Особливій частині Кримінального кодексу України [1], правоохоронцями та криміналістиками-практиками вироблені та напрацьовані методичні рекомендації щодо специфіки розслідування певних категорій злочинів.

Проте, з неухильним розвитком технічного прогресу, який нерозривно поєднаний із економічною ситуацією та господарською діяльністю країни в цілому, неминуче «удосконалюються» способи вчинення злочинів у сфері господарської діяльності, що, у свою чергу, постає причиною удосконалення методики розслідування злочинів вказаної категорії, каталізує пошук інновацій у цьому розділі загальної системи криміналістики.

Безсумнівною інновацією у методиці розслідування злочинів у сфері господарської діяльності є залучення слідчим саме на етапі проведення першопочаткових слідчих дій як профільних спеціалістів представників Державної аудиторської служби, а також державної контрольно-ревізійної служби України з метою виявлення та документування злочинної діяльності на вказаній ділянці правового поля, що, у свою чергу, $\epsilon$ гарантом якісного та об'єктивного виконання завдань Кримінального процесуального кодексу України [2].

Так, участь спеціаліста у досудовому розслідуванні в межах кримінального провадження регламентована статтями 71, 79 Кримінального процесуального кодексу України [2] та розділом 3 Порядку взаємодії між органами державної контрольноревізійної служби та органами прокуратури, внутрішніх справ і Служби безпеки України, затвердженим спільним наказом від 19.10.2006 № 346/1025/685/53, зареєстрованим у Мін'юсті 25 жовтня 2006 року за№ 1166/13040 (далі - Порядок взаємодії)[3].

Необхідно зазначити, що виділення профільного спеціаліста можливе в разі: наявності у правоохоронного органу відкритого кримінального провадження (виключення ст. 25 Закону України «Про службу безпеки України»[4], статті 12 Закону України «Про організаційно-правові основи боротьби 3 організованою злочинністю»[5] та статті 26 Закону України «Про прокуратуру»[6]), відповідності звернення правоохоронного органу вимогам п. 3.2. Порядку взаємодії [3].

3 метою виявлення, фіксації слідів порушень вимог законодавства та встановлення наявності ознак злочинів у сфері господарської діяльності, що має місце в діяльності суб'єкта господарювання, правоохоронними органами призначається фінансовий аудит його діяльності. 


\section{Кримінальне право, кримінальний процес та криміналістика}

Так, аудит - це перевірка даних бухгалтерського обліку і показників фінансової звітності суб'єкта господарювання з метою висловлення незалежної думки аудитора про іï достовірність в усіх суттєвих аспектах та відповідність вимогам законів України, положень (стандартів) бухгалтерського обліку або інших правил (внутрішніх положень суб'єктів господарювання) згідно із вимогами користувачів [7, с.17].

Зокрема, під час залучення профільних спеціалістів - представників Державної аудиторської служби та державної контрольно-ревізійної служби України для здійснення ревізії суб'єкта господарювання (небюджетної установи) слідчим має бути визначено та надано останнім перелік обов'язкових для перевірки напрямів:

1. Стан усунення порушень, недоліків, виявлених попередніми ревізіями.

Під час документування результатів перевірки цього питання зазначається :

- інформація щодо останньої планової ревізії, проведеної у суб'єкта господарювання органами Держфінінспекції або державної контрольно-ревізійної служби, а також усіх інших проведених органами Держфінінспекції або державної контрольно-ревізійної служби ревізій (перевірок) за період, що підлягав ревізії (реквізити актів чи інших документів про результати контрольних заходів; періоди, що підлягали контролю; назви органів, які проводили контрольні заходи; питання, що підлягали контролю (в разі, коли контрольні заходи проводились 3 окремих питань);

- інформація щодо усунення виявлених попередніми ревізіями (перевірками) порушень та недоліків.

2. Відповідність фактичної діяльності підприємства видам діяльності, передбаченим статутом зазначеної юридичної особи, регуляторними актами та дозвільними документами останньої.

У ході документування результатів перевірки цього питання зазначається:

- наявність документів про реєстрацію суб'єкта господарювання в органах державної влади;

- відповідність видів діяльності, що передбачені статутом суб'єкта господарюван- ня, видам діяльності, на які видані ліцензії, сертифікати, квоти, дозволи тощо;

- відповідність видів діяльності, що передбачені статутом суб'єкта господарювання, фактичній діяльності останнього протягом періоду, який підлягає ревізії.

3. Перевірка фінансових планів, стану їх виконання.

Під час документування результатів перевірки цього питання зазначається:

- дотримання встановленої законодавством процедури складання, затвердження (погодження) фінансового плану та внесення змін до нього;

- обгрунтованість показників фінансового плану; дотримання граничного обсягу встановлених законодавством витрат;

- стан виконання фінансового плану.

4. Проведення безготівкових операцій у національній та іноземній валюті.

У ході документування результатів перевірки цього питання зазначається:

- інформація про всі рахунки, які було відкрито суб'єктом господарювання в установах банків, органах Державної казначейської служби у період, що підлягав ревізії, а саме: номери рахунків, у яких установах їх відкрито, дати їх відкриття та закриття у період, що підлягав ревізії;

- дотримання законодавства при відкритті, використанні і закритті рахунків суб'єкта господарювання;

- дотримання законодавства під час списання коштів з рахунків суб'єкта господарювання;

- дотримання законодавства при здійсненні операцій по зарахуванню коштів на рахунки суб'єкта господарювання.

5. Проведення безготівкових операцій у національній та іноземній валюті.

Під час документування результатів перевірки цього питання зазначається:

- наявність договору про повну матеріальну відповідальність за збереження цінностей в касі суб'єкта господарювання;

- організація фактичного контролю за збереженням наявних у касі суб'єкта господарювання коштів, у тому числі результати інвентаризації наявних коштів у касі, проведеної в ході ревізії із зазначенням підстави на проведення інвентаризації, дотримання 
строків, порядку та обов'язковості у передбачених випадках проведення інвентаризації каси;

- дотримання порядку обліку інших грошових коштів (документів та грошових коштів у дорозі);

- наявність та правильність оформлення касових документів;

- дотримання встановлених законодавством вимог щодо роботи з готівкою в касі, в тому числі: ліміту готівки в касі; своєчасності та повноти оприбуткування готівки в касу, видачі готівки на виплати, зарахування отриманих та списаних 3 каси грошових коштів на рахунки в установах банків; порядку списання готівки 3 каси;

- дотримання законодавства під час здійснення під час здійснення розрахунків 3 підзвітними особами, в тому числі : в частині відшкодування витрат на відрядження та інших витрат, проведених за рахунок підзвітних коштів; під час здійснення розрахунків $з$ підзвітними особами, в тому числі своєчасність звітування про використання коштів, виданих у підзвіт, та повернення підзвітними особами сум невикористаної готівки в касу.

6. Повнота надходження, достовірність і правильність визначення доходів.

У ході документування результатів перевірки цього питання зазначається:

- правильність визнання доходів суб'єкта господарювання;

- законність та правильність визначення доходу (виручки) від реалізації продукції (товарів, робіт, послуг);

- законність та правильність визначення інших операційних, фінансових, надзвичайних та інших доходів;

- результати перевірки ціноутворення;

- законність та повнота отримання доходів;

Вплив фактів неврахування доходів на формування чистого прибутку (збитку) суб'єкта господарювання та перерахування до бюджету частини чистого прибутку (доходу) або дивідендів.

7. Законність здійснення та достовірність відображення витрат.

Під час документування результатів перевірки цього питання зазначається:
- аналізи витрат у розрізі їх видів та років здійснення;

- правомірність віднесення витрат до собівартості реалізованої продукції;

- правомірність, здійснення витрат операційної діяльності, які не включаються до собівартості реалізованої продукції;

- правильність формування витрат операційної діяльності за економічними елементами витрат;

- правомірність здійснення фінансових витрат;

- результати перевірки втрат від участі в капіталі;

- правомірність здійснення інших витрат, які виникають під час звичайної діяльності, але не пов'язані безпосередньо 3 виробництвом та/або реалізацією продукції (товарів, робіт, послуг).

8. Правильність відображення дебіторської та кредиторської заборгованості. Стан претензійно-позовної роботи.

У ході документування результатів перевірки цього питання зазначається:

- наявність та реєстрація договорів;

- дотримання строків та порядку проведення інвентаризації розрахунків;

- наявність дебіторської і кредиторської заборгованості (в межах терміну позовної давності), достовірність іiі виникнення, в тому числі:

1) стан нарахування можливих санкцій за несвоєчасне погашення простроченої дебіторської заборгованості;

2) причини виникнення простроченої кредиторської заборгованості та можливі наслідки не погашення такої заборгованості;

3) достовірність заборгованості за наявними у суб'єкта господарювання документами, результати зустрічних звірок з питань підтвердження заборгованості;

- правильність визнання зобов'язань;

- наявність в обліку безнадійної дебіторської та кредиторської заборгованості, в тому числі заборгованості, за якою минув термін позовної давності, причини виникнення безнадійної заборгованості;

- забезпечення зобов'язань та резерв сумнівних боргів;

- перевірка розрахунків за товарообмінними операціями; 


\section{Кримінальне право, кримінальний процес та криміналістика}

- перевірка розрахунків за претензіями та відшкодування збитків;

- перевірка розрахунків щодо зовнішньоекономічної діяльності;

- відповідність сплаченої вартості товарів, робіт та послуг умовам укладених договорів;

- відповідність кількості та асортименту отриманих товарів, робіт та послуг умовам договорів;

- стан проведення претензійно-позовної роботи.

9. Дотримання законодавства при здійсненні державних закупівель.

Під час документування результатів перевірки цього питання зазначається:

- дотримання законодавства при створенні комітету з конкурсних торгів;

- наявність річного плану закупівель, обгрунтованість його показників та правомірність внесення змін до нього;

- дотримання порядку вибору процедур закупівель;

- прозорість здійснення державних закупівель:

- відповідність документації конкурсних торгів, кваліфікаційної документації та запиту для участі у процедурі цінових пропозицій вимогам законодавства;

- дотримання порядку надання комітетом з конкурсних торгів роз'яснень у зв'язку із унесенням змін до документації конкурсних торгів або на запити учасників;

- відповідність конкурсних пропозицій (цінових пропозицій) вимогам документації конкурсних торгів (запрошення до участі в торгах) та законодавству;

- дотримання порядку розгляду та оцінки конкурсних пропозицій, визначення переможця, акцепту конкурсної пропозиції переможця торгів;

- дотримання законодавства при застосуванні процедури закупівлі в одного учасника;

- відповідність умов укладених договорів вимогам документації конкурсних торгів, умовам конкурсної пропозиції; виконання умов укладених договорів;

- достовірність звітів про результати процедури закупівлі;
- аналіз закупівельних цін на товари, роботи і послуги.

10. Стан збереження державного майна, використання оборотних та необоротних активів.

У ході документування результатів перевірки цього питання зазначається:

- стан закріплення всіх необоротних активів та запасів за матеріально-відповідальними особами; наявність договорів про матеріальну відповідальність;

- дотримання періодичності та порядку проведення інвентаризації необоротних активів та запасів, правильність оформлення та відображення в бухгалтерському обліку їі результатів;

- результати проведеної під час ревізії інвентаризації необоротних активів, запасів, незавершеного будівництва;

- обгрунтованість придбання, рух та повнота відображення запасів суб'єкта господарювання;

- обгрунтованість придбання, рух та повнота відображення основних засобів суб'єкта господарювання;

- обгрунтованість придбання, рух та повнота відображення нематеріальних активів;

- дотримання законодавства при наданні в оренду оборотних та необоротних активів суб'єкта господарювання та оренді оборотних та необоротних активів;

- результати перевірки здійснення капітальних інвестицій.

11.Дотримання законодавства при отриманні та використанні бюджетних коштів (за наявністю)

Під час документування результатів перевірки цього питання зазначається:

- наявність затвердженого плану використання бюджетних коштів у разі отримання коштів за бюджетною програмою та включення суб'єкта господарювання до мережі одержувачів бюджетних коштів;

- відповідальність суб'єкта господарювання встановленим законодавством критеріям одержувача бюджетних коштів;

- аналіз економічного обгрунтування обсягу та доцільності отримання суб'єктом господарювання коштів; 
- законність отримання та використання коштів дотацій, субвенцій, субсидій тощо;

- результати перевірки цільового використання бюджетних коштів;

- законність укладання договорів щодо освоєння бюджетних коштів, дотримання термінів виконання робіт, доцільність придбання основних засобів, обладнання, офісної техніки, інвентарю та інших матеріальних цінностей для виконання робіт;

- стан досягнення мети, на яку виділялись бюджетні кошти. пітал.

12. Фінансові результати та власний ка-

У ході документування результатів перевірки цього питання зазначається:

- правильність визначення фінансових результатів, вплив встановлених порушень на визначення фінансових результатів;

- правомірність розподілу прибутку;

- правильність визначення розміру частини прибутку (доходу), який спрямовується до бюджету;

- правильність формування статутного капіталу, відповідність даних про розмір статутного капіталу, визначених в установчих документах, даним бухгалтерського обліку, правомірність змін статутного капіталу;

- правильність формування додаткового капіталу і законність його використання;

- правильність формування резервного капіталу і законність його використання;

- правомірність формування інших фондів, створених за рахунок чистого прибутку та законність їх використання.

13. Стан бухгалтерського обліку та достовірність фінансової звітності.

Під час документування результатів перевірки цього питання зазначається дотримання порядку організації ведення бухгалтерського обліку, складання фінансової звітності та іiі достовірність (крім фактів порушень, зазначених у ході документування інших питань ревізії).

Як висновок до статті зазначимо, що, на нашу думку, злочини у сфері господарської діяльності є досить специфічним явищем злочинної діяльності, яка постійно розвивається 3 неминучим розвитком технічного прогресу та господарської діяльності держави. Саме ця новизна та специфічність, неухильний та постійний розвиток вказаного виду злочину вимагають від судових та правоохоронних органів, криміналістів розроблення та застосування нових криміналістичних засобів та методів у їх виявленні та фіксації для подальшого невід'ємного використання у проведенні ефективного розслідування, встановленні та притягненні винних осіб до відповідальності.

Зважаючи на наявність недоліків у цій сфері процесуально-правової та експертно-криміналістичної діяльності, вважаємо за актуальні подальші дослідження відповідної спрямованості, адже останні створюватимуть перспективи теоретичних та практичних напрацювань та сприятимуть розв'язанню проблемних питань на цьому напрямку.

\section{література}

1. Кримінальний кодекс України. Закон України від 5 квітня 2001 року №2341-III (редакція станом на 01.10.2020) [Електронний pecypc] : http://zakon.rada.gov.ua (дата звернення: 08.10.2020).

2. Кримінальний процесуальний кодекс України. Закон України від 13 квітня 2012 року №4651-VI (редакція станом на 01.10.2020) [Електронний ресурс] : http://zakon.rada.gov.ua (дата звернення: 08.10.2020).

3. Порядку взаємодії між органами державної контрольно-ревізійної служби та органами прокуратури, внутрішніх справ і Служби безпеки України, затвердженим спільним наказом від 19.10.2006№ $\quad 346 / 1025 / 685 / 53, \quad$ зареєстрованим у Мін'юсті 25 жовтня 2006 року за№ 1 166/13040 (редакція станом на 01.10.2020) [Електронний ресурс] : http://zakon.rada. gov.ua (дата звернення: 08.10.2020).

4. Закон України від 25 березня 1992 року № 2230-XII «Про службу безпеки України» (редакція станом на 03.07.2020) [Електронний ресурс] : http://zakon.rada. gov.ua (дата звернення: 08.10.2020).

5. Закон України від 30 червня 1993 року № 3342-XII «Про організаційно-правові основи боротьби з організованою злочинністю» (редакція станом на 03.07.2020) 


\section{АНОТАЦІЯ}

Викладаються правові основи та перспективи розвитку криміналістики в світлі нових кримінальних загроз при стрімкому поширенні вчинення злочинів у сбері господарсъкої діяльності. Розглянуто процесуально-правові та експертно-криміналістичні питання щодо можливості виявлення, біксаџї та збирання слідової картини та бормуванні доказової бази у вчиненні злочинів у сбері господарсъкої діяльності, а також обгрунтовано необхідність еØективної співпраці працівників слідчих органів, суду та профільних спеиіалістів Державної аудиторсъкої служби, а також державної контрольно-ревізійної служби Украӥни для якісного та об'єктивного виконання завдань кримінального провадження та покращення інновачійної політики України. Наведені конкретні приклади завдань, які ставились на вирішення пробільних спещіалістів у галузі проведення аудиту господарсъкої діяльності суб'єкта правовідносин, що мало місце на практиці. Зроблені висновки та надані рекомендаиї щодо узгодженого застосування норм діючого законодавства у практичній діяльності спеціаліста-аудитора та слідчого. Привернуто увагу на необхідність подальшої наукової співпраці вчених, спещіалістів у галузі матеріального та процесуального права.

Ключові слова: криміналістика, злочин, метод, аудит, господарсъка діяльність, інбормація, правоохоронні органи, досудове розслідування, кримінальне провадження, експертиза, експерт, спеиіаліст.

[Електронний ресурс] : http://zakon.rada. gov.ua (дата звернення: 08.10.2020).

6. Закон України від 28 грудня 2014 року № 76-VIII «Про прокуратуру» (редакція станом на 03.07.2020) [Електронний ресурс]
: http://zakon.rada.gov.ua (дата звернення: 08.10.2020).

7. Петренко С. М., Пальиун I. М., Аудит: теорія і практика застосування міжнародних стандартів: навч. посіб. - [2-ге видання]. - Львів: «Магнолія 2006», 2016. - 520 с.

\section{Osmolian, V.A. \\ AUDIT AS AN INTEGRAL PART OF THE FORENSIC METHODOLOGY OF INVESTIGATION OF CRIMES IN THE SPHERE OF ECONOMIC ACTIVITY}

In the article the author lays out the basics and prospects for the development of criminology in the light of new criminal threats with the rapid spread of crimes in the sphere of economic activity. Procedurallegal and expert-criminological issues concerning the possibility of detection, fixation and collection of a trace picture and formation of an evidence base in commission of crimes in the sphere of economic activity are considered. And also the necessity of effective cooperation of employees of investigative bodies of court and profile specialists of the State Audit Service and the state control and audit service of Ukraine for qualitative and objective performance of tasks of criminal proceedings and improvement of innovation policy of Ukraine is substantiated. Specific examples of tasks set for the solution of specialized specialists in the field of auditing the economic activity of the subject of legal relations, witch took place in practice. Conclusions are made and recommendations are given on the coordinated application of the current legislation in the practice of a specialist auditor and investigator. Attention is drawn to the need for further scientific cooperation of scientists, specialists in the field of substantive and procedural law.

Keywords: criminalistics (criminology), crime, method, audit, economic activity, information, criminal proceedings, police, pre-trial investigation, expertise, expert, specialist. 


\title{
МЕЖІ СУДОВОГО РОЗГЛЯДУ
}

\author{
КОРЕЦЬКА Вікторія Віталіївна - суддя Ківерцівського районного суду \\ Волинської області \\ orcid.org 0000-0002-5685-5337
УДК 347.93.94 \\ DOI 10.32782/LAW.2020.3.16
}

\begin{abstract}
Проведение рефбормв уголовного прочессуального законодательства предоставила новые ялементы построения уголовного процесса. Определено, что предель судебного разбирательства связанъ предварительньм судебнылм производством. Процессуальнъие полномочия судъи, установленнъие действуюшим законодательством, соответствуют международнъим правовъим нормам и обеспечивают выполнение прав, свобод и гарантий участников уголовного производства. Предель судебного разбирательства уголовного производства проводится в отношении обвиняемого в соответствии с обвинительного акта. Изменение обвинения может осуществляться публичнъмм обвинителем.

Предложень теоретические аспекты и практическое решение даннъх вопросов и внесения изменений в действующее законодательство.

Ключевъие слова: границь, механизм, статус, следователь, прокурор, судья, обвиняемъии, судебное разбирательство, приговор.
\end{abstract}

Актуальність статті полягає в тому, що за чинним КПК України слідчий складає обвинувальний акт, який затверджує прокурор та направляе його до суду. Суддя, отримавши обвинувальний акт повинен розглянути його у підготовчому судовому провадженні та призначити судовий розгляд кримінального провадження. Межі підготовчого судового провадження визначені ст. 314 КПК України, однак подальший термін судового розгляду встановлений за розумними строками кримінального процесу. Тому суддя має право розглядати кримінальну справу до встановлення об'єктивної істини.

КПК України 1961 року встановлював аспекти повернення кримінальної справи для проведення додаткового розслідування, усунення прогалин досудового розслідування не на судових стадіях процесу, а на стадії досудового провадження. Прокурор під час додаткового досудового розслідування приймав рішення щодо закриття кримінального провадження.

Чинний КПК України скасував методику повернення кримінальної справи прокурору, суддя повинен на підставі судових доказів встановити обставини кримінального правопорушення. Він встановлюе вину обвинуваченого та відповідає за вирок.

Ст. 337 КПК України встановила загальні положення визначення межі доказування судового розгляду кримінального провадження, а саме судовий розгляд проводиться стосовно обвинуваченого відповідно до обвинувального акту. Однак, до кінця не визначено процедуру та механізм меж судового розгляду.

Мета статі полягає у визначенні межі судового розгляду, розкрити процедуру та механізм перевірки доказів, які знайшли свій вираз під час судового розгляду. Суддя повинен визначити межі обставин кримінального правопорушення, встановити вину обвинуваченого на підставі його показань, 


\section{Кримінальне право, кримінальний процес та криміналістика}

скласти обвинувальний вирок, а саме виконати завдання кримінального процесу.

Теоретичні положення можна встановити на підставі процесуальної діяльності суду у кримінальному процесі, яка була предметом наукових дискусій вчених, що визначали процесуальний статус судді, законність процесуальних рішень суду, встановили межі судового розгляду. Основні теоретичні розробки були наданіЮ.П. Аленіним, М.І. Бажановим, Л.О. Богословською, В.Д. Бринцевим, Е.Г. Веретехіним, Ю.М. Грошевим, О.М. Дроздовим, О.В. Капліною, В.Т. Маляренко, Д.В. Філіним, О.Г. Шило, О.Г. Яновською та ін. [1; 3; 4 , с. $206-209 ; 5$, с. $100 ; 8 ; 9 ; 12 ; 15 ; 16$, с. 15 ; 19 , c. $129 ; 20]$.

Перші положення процесуальної діяльності суду були розроблені у 1879 р. К.Д. Анціферовим, у 1898 р. В .Ф. Дерюжинським та ін., які встановили межі судового розгляду на підставі функції справедливості щодо обвинуваченого під час судового розгляду. У такому разі, якщо вирок суду відповідав наслідкам вчиненого кримінального правопорушення, то функція суду була виконана [2].

На підставі розподілу функцій у кримінальному процесі функція суду була відокремлена від процесуальної діяльності органу досудового розслідування. Суддя став самостійним під час судового розгляду та незалежним від впливу інших гілок влади.

I.B. Гловюк, Т.Н. Добровольская та ін. надали аналіз процесуальних функцій суду, на підставі яких було визначено межі судового розгляду. Вони вважали, що суддя під час судового розгляду встановлюе обставини кримінального правопорушення та докази вини обвинуваченого. Чинний КПК України встановив участь сторін під час судового розгляду кримінальної справи тому процесуальна діяльність суду є статус арбітра, який слухає висновки сторін та оцінює надані фактичні дані, що свідчать про вину, або невинуватість обвинуваченого. Межі судового розгляду встановлені обставинами кримінального правопорушення та доказами, що вказують на вину обвинуваченого $[10 ; 11]$.
М.І. Бажанов, Ю.М. Грошевой, А.Д. Зусь та ін. розглядали процесуальні межі правової діяльності суду та визначили елементи правотворчості. Окремі положення встановлення обставин кримінального правопорушення суддя повинен використовувати на підставі рішень Конституційного, Верховного, Європейського Суду з прав людини. Вирок суду повинен відповідати не тільки обставинам кримінального злочину, з точки зору матеріального права, а також основної концепції Європейської судової практики $[3 ; 9 ; 13]$.

На підтвердження цієї позиції Д.П. Великий, О.М. Овчаренко та ін. вважали, що диспозиція процесуальних норм повинна бути забезпечена примусовою силою держави. Вони вважали, що публічне та приватне право присутне у кримінальному процесі. Публічне право захищає інтереси особи, суспільства, держави від кримінального правопорушення. Приватне право включає до себе елементи позовної заяви, яка подається учасником кримінального провадження та спрямована на захист прав, свобод, інтересів та відшкодування матеріальної шкоди $[7$, с. 10; 17].

В.T. Маляренко надав положення юридичної практики суду та вказував, що вона має наступні напрямки, зокрема орієнтує суддю для прийняття процесуального рішення та ухвалення вироку; конкретизує права та обов'язки судді для встановлення меж оцінки доказів, встановлення обставин кримінального правопорушення, визначення кваліфікації за КК України відносно обвинуваченого; інформаційні результати розгляду кримінальних проваджень Вищим Судом, отримання ухвали, рішення Верховного суду для орієнтації визначення кваліфікаційних положень вчинення кримінального правопорушення [16, с. 15].

Опоненти вважали, що процесуальна діяльність суду пов'язана не тільки обвинувальним актом, а також результатом судового розгляду клопотання слідчого, прокурора на стадії досудового розслідування. Вони звертали увагу на те, що процедура отримання ухвали слідчого судді на стадії досудового розслідування має ознаки церемонії, ніж процесуального визначення. Суддя не 
знайомиться 3 матеріалами справи, оскільки досудове розслідування має тільки початковий період, зміна обвинувачення може здійснюватися протягом усього досудового провадження. Крім того, суддя не має механізму перевірки наданої ухвали, оскільки слідчий не повідомляе судді про результати іï виконання.

С.Б. Росінський, Д.В. Філін та ін. вважали, що слідчий суддя на стадії досудового розслідування повинен здійснювати судовий контроль за процесуальною діяльністю слідчого, прокурора. Результати виконання ухвали слідчого судді під час судового розгляду кримінального провадження повинні бути перевірені [18, с. 17; 19, с. 129].

3 даних теоретичних аспектів можна надати приклад. На підставі ст.225 КПК України, проведення допиту слідчим суддею на стадії досудового провадження. Якщо протокол допиту учасника кримінального провадження на стадії судового розгляду підлягає перевірки, то протокол допиту слідчим суддею є судовим доказом, який може бути покладений у вирок. Однак, механізм проведення даного допиту до кінця не визначено. Слідчий не може знати у який термін він повинен надати клопотання слідчому судді для проведення допиту учасника процесу. Необхідно забезпечення охорони учаснику процесу. Які межі допиту повинні бути встановлені слідчим суддею, оскільки він не володіє матеріалами кримінального провадження в повному обсягу.

\section{Виклад загального матеріалу}

Встановлення межі судового розгляду необхідно визначити на підставі загальних положень кримінального процесу. Пропонуємо наступні форми встановлення межі судового провадження. Перша форма передбачає судовий розгляд кримінальної справи, встановлення обставин кримінального правопорушення, складання вироку. Друга - зміна обвинувачення під час судового розгляду прокурором; визначення додаткового обвинувачення стороною обвинувачення; відмова від підтримання державного обвинувачення прокурором. Третя форма встановлення неповноти судового розгляду; невідповідність висновків суду, викладених у судовому рішенні, фактичним обставинам кримінального провадження; істотне порушення вимог кримінального процесуального закону; неправильне застосування закону України про кримінальну відповідальність; невідповідність призначеного покарання тяжкості кримінального правопорушення та особі обвинуваченого.

На підставі цих форм можна надати теоретичну модель статусу судді на стадії судового розгляду. Основний елемент статусу судді встановлений Конституцією України, як гілки судової, державної влади. Суддя є незалежним у своїй процесуальної діяльності та підкоряється тільки закону та виконує його. Друга конструкція статусу судді включає процесуальні аспекти, які визначені та закріплені у чинному КПК України. Процесуальні права, обов'язки судді є фундаментом для законного, неупередженого ухвалення вироку. На підставі завдань, мети кримінального процесу, які встановлені сукупністю правових елементів вини обвинуваченого, суддя повинен визначити межі обвинувачення та встановити істину.

Теоретичні та практичні проблеми кримінального процесу включають аспекти процесуальної діяльності суду під час оцінки доказів, що надані органом досудового розслідування та прокурором. Незважаючи на те, що суддя бере участь у встановленні обставин кримінального правопорушення, проводить допит учасників судового розгляду, перевіряє докази, заслуховує доводи обвинувачення з боку публічного обвинувача та доводи сторони захисту щодо оцінки доказів, які вказують на вину обвинуваченого, він пов'язаний обвинувальним актом та матеріалами кримінального провадження.

Статистичні дані Верховного Суду України вказують, що $65 \%$ органи досудового розслідування надають матеріали кримінального провадження, а під час судового розгляду суддя встановлює порушення процесуальних норм. 35\% під час судового розгляду кримінального провадження суддя встановлює неправильну кваліфікацію про кримінальну відповідальність [21].

Основна тенденція процесуальної діяльності судді полягає в тому, щоб диференціювати кримінальну відповідальність, звузити 


\section{Кримінальне право, кримінальний процес та криміналістика}

застосування репресивних заходів впливу до обвинуваченого. Тільки після ретельної перевірки обставин кримінального правопорушення суддя має право проголосити вирок. Норми чинного КПК України встановлюють предмет доказування, його межі, які є однакові для досудового та судового провадження.

Межі судового розгляду, за чинним КПК України, мають нові правові конструкції. Перша включає зміну обвинувачення під час судового розгляду прокурором, визначення додаткового обвинувачення стороною обвинувачення. Друга - відмова від підтримання публічного обвинувачення прокурором. Суддя під час судового розгляду повинен встановити два взаємопов'язані аспекти, зокрема визначити обвинувачення в цілому та визначити окремі його епізоди. Тим самим він повинен або підтвердити обвинувачення, або визначити обставини, які вказують на зміну обвинувачення прокурором.

Аналіз практики, перевірка 400 кримінальних проваджень у судах Волинської, Київської, Харківської областях свідчить про недоліки процесуальної діяльності слідчого під час складання обвинувального акту. У цьому разі можна зазначити, що у $50 \%$ випадків є порушення процедури та відсутність єдиного визначення обвинувачення, зокрема: неконкретність формулювання. 25\% можна відзначити неточність кваліфікації кримінального правопорушення. $15 \%$ - формулювання обвинувачення за обсягом і змістом відрізняється від описової частини. $10 \%$ - слідчий неправильно визначає матеріальний склад вини підозрюваного.

Практика вказує на проблеми формулювання обвинувачення 3 «деяким запасом кримінального правопорушення». Суддя змушений змінити кваліфікацію під час проголошення вироку.

\section{Висновок}

Межі судового розгляду повинні проводиться відносно обвинуваченого та на підставі обвинувачення відповідно до обвинувального акту. Зміна обвинувачення повинна мати випадковий зміст. Публічний обвинувач має право змінити обвинувачен- ня тільки, якщо воно не погіршує процесуального статусу обвинуваченого.

\section{Аітература \\ 1. Аленин Ю. П. Уголовно-} процессуальный кодекс Украины Науч. практ. комментарий / Ю. П. Аленин. Харків: Одисей, 2003. - 959 с.

2. Анциферов К. Д. Обвинительное начало и английский процесс / К. Д. Анциферов // Юридический вестник. - Москва, 1879. - С. 432.

3. Бажанов М.И. Производство дознания в органах милиции. /М.И. Бажанов, А.Д. Коган// -Х.: 1956. - 110с.

4. Богословська $\lambda$. О. Апеляційне провадження: історія виникнення в Україні /ᄉ. О. Богословська // Судова реформа в Україні: проблеми і перспективи: Х.: Юрінком Інтер, 2002. - С.206-209.

5. Брынцев В. Д. Судебная власть. Правосудие. Пути реформирования в Украине / В. Д. Брынцев. - Харьков : Основа, 1998. - 140 c.

6. Бережной O.I. Преюдиціальність судових рішень у кримінальних справах. /O.I. Бережной. - Х. СПД. ФО Вапнярчук M.M. 2006. - С. 28.

7. Великий Д. П. Единство и дифференциация уголовно- процессуальной формы : автореф. дис. ... канд. юрид. наук : 12.00.09/ Д. П. Великий. - Москва, 2001. - 20 с.

8. Веретехин Е.Г. Пробелы предварительного расследования и их восполнение в суде 1 инстанции / Е.Г. Веретехин. - Казань. Казанский гос. Ун-ь. 1988. - 160с.

9. Грошевой Ю.М. Нове у кримінально - процесуальному законодавстві України /Ю.М.Грошевой, Т.М.Мірошниченко. - Х.: Основа. 2002. - 110с.

10. Гловюк I.B. Кримінально процесуальні функції: теорія, методологія та практика реалізації на основі положень Кримінального процесуального кодексу України /І.В. Гловюк - Одеса: Юридична література. 2015. - 712c.

11. Добровольская Т. Н. Изменение обвинения в судебных стадиях советского уголовного процесса / Т. Н. Добровольская. Москва : Юрид. лит., 1977. - 151 с. 
12. Дроздов О.М. Судові прецеденти - джерела кримінального процесуального права України / О.М. Дроздов/ Актуальні проблеми кримінального права, процесу та криміналістики - Одеса. Фенікс. 2010. -C. 124-127.

13. Зусь А.Д. Механизм правового регулирования. /А.Д.Зусь// Владивосток.: Дальневосточ. Владивост. Ун-т. 1976. - 190с.

14. Ковтун Н.Н. Судебный контроль в уголовном судопроизводстве России. /Н.Н.Ковтун// -Нижний Новгород.: Нижегододская правовая академия. 2002. -332с.

15. Капліна О.В. Кримінальний процес України: підручник / О.В. Капліна,Ю.М. Грошевой, О.В. Шило. - Х. Юрид. університет. 2013. - 820c.

16. Маляренко В. Т. Найпоширеніші помилки та порушення законів, які допускаються при провадженні дізнання і попереднього слідства / В. Т. Маляренко // Право України. - Київ : МЮ України, 2001. - № 3. - C. 15.

17. Овчаренко О.М. Доступність правосуддя та гарантії його реалізації / О.М. Овчаренко: монографія. - Харків. Право. 2008. 280c.

18. Росинский С. Б. Нужен ли предварительный судебный контроль за производством следственных действий в жилище? / С. Б. Росинский. - Российский судья, 2009. - № 8. - С. 17-21.

19. Филин Д.В. Методологические проблемы процессуально-правовых исследований. / Д.В.Филин // Правовой аспект. -Воронеж. ВГУ. № 1. 2007 -С. 129-135.

20. Яновська О.Г. Концептуальні засади функціонування і розвитку змагального кримінального судочинства / О.Г. Яновська: монографія. - К. Прецедент. - 2011 - 308с.

21. Практика Верховного Суду України [електронний ресурс: режим доступу: http:// www.scourt.gov.ua].

\section{References}

1. Alenin Ju. P. Ugolovno-processual'nyj kodeks Ukrainy Nauch. prakt. kommentarij / Ju. P. Alenin. Harkiv : Odisej, 2003. - 959 s.

2. Anciferov K. D. Obvinitel'noe nachalo i anglijskij process / K. D. Anciferov // Juridicheskij vestnik. - Moskva, 1879. - S. 432.
3. Bazhanov M.I. Proizvodstvo doznanija v organah milicii. /M.I. Bazhanov, A.D. Kogan// -H.: 1956. - 110s.

4. Bogoslovs'ka L. O. Apeljacijne provadzhennja: istorija viniknennja v Ukraïni / L. O. Bogoslovs'ka // Sudova reforma v Ukraïni: problemi i perspektivi: H.: Jurinkom Inter, 2002. - S.206-209.

5. Bryncev V. D. Sudebnaja vlast'. Pravosudie. Puti reformirovanija v Ukraine / V. D. Bryncev. - Har'kov : Osnova, 1998. - 140 s.

6. Berezhnoj O.I. Prejudicial'nist' sudovih rishen' u kriminal'nih spravah. /O.I. Berezhnoj. - H. SPD. FO Vapnjarchuk M.M. 2006. S. 28

7. Velikij D. P. Edinstvo i differenciacija ugolovno- processual'noj formy : avtoref. dis. ... kand. jurid. nauk : 12.00.09 / D. P. Velikij. Moskva, 2001. - $20 \mathrm{~s}$.

8. Veretehin E.G. Probely predvaritel'nogo rassledovanija $\mathrm{i}$ ih vospolnenie $\mathrm{v}$ sude 1 instancii / E.G. Veretehin. - Kazan'. Kazanskij gos. Un-'. 1988. - 160s.

9. Groshevoj Ju.M. Nove u kriminal'no - procesual'nomu zakonodavstvi Ukraïni / Ju.M.Groshevoj, T.M.Miroshnichenko. - H.: Osnova. 2002. - 110s.

10. Glovjuk I.V. Kriminal'no procesual'ni funkciï: teorija, metodologija ta praktika realizaciï na osnovi polozhen' Kriminal'nogo procesual'nogo kodeksu Ukraïni /I.V. Glovjuk - Odesa: Juridichna literatura. 2015. - 712s.

11. Dobrovol'skaja T. N. Izmenenie obvinenija $\mathrm{v}$ sudebnyh stadijah sovetskogo ugolovnogo processa / T. N. Dobrovol'skaja. Moskva : Jurid. lit., 1977. - 151 s.

12. Drozdov O.M. Sudovi precedenti dzherela kriminal'nogo procesual'nogo prava Ukraïni / O.M. Drozdov/ Aktual'ni problemi kriminal'nogo prava, procesu ta kriminalistiki - Odesa. Feniks. 2010. - S. 124-127.

13. Zus' L.D. Mehanizm pravovogo regulirovanija. /L.D.Zus'// Vladivostok.: Dal'nevostoch. Vladivost. Un-t. 1976. - 190s.

14. Kovtun N.N. Sudebnyj kontrol' v ugolovnom sudoproizvodstve Rossii./N.N.Kovtun// -Nizhnij Novgorod.: Nizhegododskaja pravovaja akademija. 2002. -332s.

15. Kaplina O.V. Kriminal'nij proces Ukraïni: pidruchnik / O.V. Kaplina, Ju.M. Gro- 


АНОТАЦІЯ
Проведення реборми кримінального проче-
суального законодавства надала нові елементи
побудови кримінального процесу. Визначено, ияо
межі судового розгляду пов'язані підготовчим
судовим провадженням. Процесуальні повно-
важення судді, встановлені чинним законодав-
ством відповідають міжнародним правовим
нормам та забезпечують виконання прав, сво-
бод та гарантій учасників кримінального про-
вадження. Межі судового розгляду криміналь-
ного провадження проводиться стосовно обви-
нуваченого відповідно до обвинувального акту.
Зміна обвинувачення може здіиснюватися
публічним обвинувачем.
Запропоновано теоретичні аспекти та
практичне вирішення даних питань та вне-
сення змін до чинного законодавства.
Ключові слова: межі, механізм, статус,
слідчий, прокурор, суддя, обвинувачений, судо-
вий розгляд, вирок.

shevoj, O.V. Shilo. - H. Jurid. universitet. 2013. -820 s.

16. Maljarenko V. T. Najposhirenishi pomilki ta porushennja zakoniv, jaki dopuskajut'sja pri provadzhenni diznannja i poperedn'ogo slidstva / V. T. Maljarenko // Pravo Ukraïni. Kiïv : MJu Ukraïni, 2001. - № 3. - S. 15.

17. Ovcharenko O.M. Dostupnist' pravosuddja ta garantiï jogo realizaciï / O.M. Ovcharenko: monografija. - Harkiv. Pravo. 2008. 280s.

18. Rosinskij S. B. Nuzhen li predvaritel'nyj sudebnyj kontrol' za proizvodstvom sled-
The reform of the criminal procedural legislation is provided new elements of the construction of the criminal process. It is determined that the scope of the trial is related to the preliminary trial. The procedural powers of a judge is established by the current legislation comply with international legal norms and ensure the implementation of the rights, freedoms and guarantees of participants in criminal proceedings. Limits of trial Criminal proceedings are conducted against the accused in accordance with the indictment. A change in charge can be carried out by a public prosecutor.

Theoretical aspects and practical solution of these issues and amendments to current legislation are proposed.

Key words: boundaries, mechanism, status, investigator, prosecutor, judge, accused, trial, sentence.

stvennyh dejstvij v zhilishhe? / S. B. Rosinskij. - Rossijskij sud'ja, 2009. - № 8. S. 17-21.

19. Filin D.V. Metodologicheskie problemy processual'no-pravovyh issledovanij. / D.V.Filin // Pravovoj aspekt. -Voronezh. VGU. № 1.2007 -S. 129-135.

20. Janovs'ka O.G. Konceptual'ni zasadi funkcionuvannja i rozvitku zmagal'nogo kriminal'nogo sudochinstva / O.G. Janovs'ka: monografija. - K. Precedent. - 2011 $308 \mathrm{~s}$.

21. Praktika Verhovnogo Sudu Ukraïni [elektronnij resurs: rezhim dostupu: http:// www.scourt.gov.ua]. 


\title{
ВИДИ ПРЕДИКАТНИХ ЗЛОЧИНІВ У ВІТЧИЗНЯНОМУ КРИМІНАЛЬНОМУ ЗАКОНОДАВСТВІ
}

\author{
ГОНЧАРУК Владислав Леонідович - аспірант Національної академії \\ Служби безпеки України \\ УДК 343.2/.7 \\ DOI 10.32782/LAW.2020.3.17
}

Постановка проблеми

Особливості легалізації (відмиванню) майна, одержаному злочинним шляхом виражаються у прямій залежності від інших кримінально караних діянь. У першу чергу, це пов'язано з тим, що саме сукупність злочинних дій, охоплених категорією «легалізація (відмивання) майна», є тим засобом, який дозволяе придати відносно законного вигляду активам, попередньо одержаних у результаті вчинення інших суспільно небезпечних дій, які як у теорії, так і на практиці визначаються умовною категорією «предикатні кримінальні правопорушення»

Такий інструмент уже досить тривалий час 6 одним із найпоширеніших кримінальних правопорушень у силу високого рівня запиту «злочинного світу» на його використання, який фактично не обмежується теренами нашої держави.

Саме поєднання «легалізації (відмивання) майна, одержаного злочинним шляхом», яка згідно 3 Кримінальним кодексом України визначна у ст. 209, з іншими злочинними діями зумовлює його особливу суспільну небезпечність.

Аналіз останніх наукових публікацій

Проблеми кримінальної відповідальності за легалізацію (відмивання) доходів, одержаних злочинним шляхом, завжди була у центрі уваги науковців. Такий інтеpec, перш за все, зумовлений наявністю прогалин у чинному Кримінальному кодексі
України, неузгодженістю окремих норм, а також необхідністю адаптації національного законодавства до світових стандартів у цій сфері.

Проблематика кримінально-правової характеристики таких діянь висвітлювалась у наукових працях таких учених, як: Ашина Д.А., Бадзана М.I., Бажанова M.I., Бауліна Ю.В., Борисова В.І., Будзана М.I., Галочки Г.В., Киричко В.М., Кухаря В.В., Мельника М.І., Сташиса В.В., Тація В.Я., Чаричанського О.О., Тулякова В.О., Тютюгіна В.І., Ховранюка М.I. та багатьох інших. Однак, більшість фахівців, досліджуючи теоретичні та прикладні аспекти кримінальної відповідальності за злочин, передбачений ст. 209 КК України, лишили поза увагою проблематику нормативного закріплення категорії «предикатне кримінальне правопорушення (злочин)», а також їх видів. Зазначене обумовлює актуальність та вибір теми наукової праці.

Метою статті $\epsilon$ визначення кола предикатних кримінальних правопорушень та формування авторського підходу до їх класифікації.

Виклад основного матеріалу

Попередньо отримані результати дослідження дають можливість зазначити, що чинна редакція ст. 209 КК України закріплює саме юридичну конструкцію, сутнісна характеристика якої вказує на те, що вчиненню легалізації (відмиванню) майна, 


\section{Кримінальне право, кримінальний процес та криміналістика}

мають передувати будь-які кримінально карані дії, котрі прямо або опосередковано призводять на незаконного його надбання. Саме під такою конструкцією ми розуміємо дефініцію «предикатний злочин».

Слід погодитися 3 думкою вчених теоретиків кримінального права про те, що така законодавча конструкція не повязана 3 окремим «пам'ятником кримінального права» та 6 продуктом достатньо довгого періоду еволюції законодавства [1].

Аналізуючи вітчизняний закон про кримінальну відповідальність слід зазначити, що його положеннями закріплені достатньо велика кількість різних складів кримінальних правопорушень, котрі, на нашу думку, так чи інакше можуть прямо чи опосередковано призвести до повного або частково незаконного набуття майна. Звідси постає питання, у яких саме з криміналізованих чинним законодавством діянь зустрічається така юридична конструкція, а також чи всі такі злочинні дії є предикатними у розумінні чинного Кримінального кодексу України.

У наукових колах до переліку складів кримінального правопорушення (злочину), який містить конструкцію предикатного злочину цілком правильно віднесено умисне вбивство [2]. Зазначена теза, на наш погляд, підтверджується на прикладі двох його кваліфікуючих ознак: по-перше, це вбивство 3 корисливих мотивів (п. 6 ч. 2 ст. 115 ККУ), а по-друге, це вбивство з метою приховати інше кримінальне правопорушення або полегшити його вчинення (п. 9 ч. 2 ст. 115 ККУ).

Оцінюючи їх за об'єктивною стороною, вважаємо за доцільне одразу вказати на наявність принципової розбіжності між ними. Якщо така суспільно небезпечна дія як вбивство з корисливих мотивів, з одного боку, закріплене в положеннях законодавства як окремих склад злочину, з другого боку, передбачає наявність кількох злочинних дій, одне з яких передує іншому, а 3 третього - зв'язок цих дій передбачає економічну вигоду у формі набуття майна, то другому злочину (п. 9 ч. 2 ст. 115 ККУ) із перерахованих властивостей остання складова не властива.
На наше переконання, фактичні обставини вчинення вбивства на замовлення (п. 11 ч. 2 ст. 115 ККУ) також дають можливість розглядати в його змісті конструкцію предикатного злочину. Разом з тим, вважаємо, що особливістю даного кримінального правопорушення є те, що воно може передбачати отримання економічної вигоди за виконання такого замовлення, однак така винагорода має необов'язковий характер, адже їі може і не бути.

Вважаємо, що наведені вище приклади засвідчують те, що фактор набуття економічної вигоди в результаті вчинення суспільно небезпечної дії, яка є злочином, 6 визначальним для розмежування цих груп предикатних конструкцій, які за законами формальної логіки співвідносяться як загальне та часткове.

Не відносяться до конструкції предикатних злочинів склади кримінальних правопорушень умисного вбивства при перевищенні меж необхідної оборони та у разі перевищення заходів, необхідних для затримання особи, яка вчинила кримінальне правопорушення (ст. 118 ККУ). Ашин Д.А. досліджуючи аналогічні групи складів 3лочину, цілком слушно вказав, що в цьому випадку хоча закон і має вказівку на іншу небезпечну дію, однак така поведінка не має жодного стосунку до основного кримінального правопорушення та $\epsilon$ протилежним йому [2]. Більше того, на підтвердження цієї тези зазначимо, що такі дії з точки зору вітчизняного кримінального законодавства розглядаються як обставини, що виключають кримінальну протиправність діяння (ст. 43 ККУ), а відтак їх необхідно розглядати саме як суспільно небезпечні дії.

Очевидним $є$ те, що 3 конструкцією предикатного злочину пов'язані кримінальні правопорушення у сфері господарської діяльності (Розділ VII ККУ).

У контексті кримінально-правової оцінки цієї групи злочинних дій розпочнемо зі складу злочину, передбаченого ст. 209 КК України «Легалізація (відмивання) майна, одержаного злочинним шляхом». У межах предмету дослідження зазначимо, що у теорії кримінального права обгрунтовано положення, згідно 3 яким 
конкретний злочинний спосіб, за допомогою якого незаконно одержано майно може виражатися у тому чи іншому кримінальному правопорушенні проти власності, одержання хабаря, вбивство з корисливих мотивів, незаконне виготовлення підакцизних товарів тощо [3].

У доповнення до зазначеного окремі фахівці до такого переліку також відносять контрабанду, шахрайство 3 фінансовими ресурсами, ухилення від сплати податків, незаконне полювання, незаконне використання товарного знака, ввезення, виготовлення, збут і розповсюдження порнографічних предметів тощо, у цілому резюмуючи, що конкретний злочинний спосіб, за допомогою якого здобуто таке майно, на кваліфікацію злочину за ст. 209 КК України не впливає [4].

Разом з тим, у 2010 році на підставі змін Закону України «Про запобігання та протидію легалізації (відмиванню) доходів, одержаних злочинним шляхом» [5] у редакції ст. 209 КК України було реалізовано, на нашу думку, достатньо дискусійну ідею обмеження кола діянь як джерела «брудних» доходів, а саме: 1) 3 кола предикатних були виключені діяння, за які згідно 3 КкУ передбачено основне покарання, менш суворе, ніж позбавлення волі, крім основного покарання у вигляді штрафу, розмір якого дорівнюе або є меншим ніж три тисячі «нмдг»; 2) як предикатні злочини не визначалися ухилення від сплати податків і зборів (обов'язкових платежів ) (ст. 212 ККУ) і ухилення від сплати єдиного внеску на загальнообов'язкове державне соціальне страхування та страхових внесків на загальнообов'язкове державне пенсійне страхування (ст. 212-1) - незалежно від того, за якою частиною цих статей кваліфіковане те чи інше діяння та яке покарання встановлено за його вчинення [3].

Опрацьовуючи цю тематику саме такого висновку дійшли у своїх працях В.М. Киричко, В.Я. Тацій, О.I. Перепелиця [6]. O.O. Чаричанський, розвиваючи ці положення, вказав також на те, що оскільки при легалізації особа намагається надати злочинним доходам правомірного вигляду, а при вчиненні діянь, передбачених ст. ст.
207 (від Авт. - нині декриміналізоване), 212 КК України, їх предмети мають абсолютно законне походження, і тому об'єктивно не можуть бути одержаними злочинним шляхом [7, с. 67].

Хоча вищевказаний підхід відповідав чинній редакції закону на той час, однак 3 таким висновком ми категорично не погоджуємось, зважаючи на кілька аспектів. По-перше, ці суспільно небезпечні дії є злочинами, а по-друге, вчинення таких 3лочинних дій, врешті-решт, дає можливість отримати економічну вигоду в порушення встановленого законом порядку, який згідно із законодавством є злочинним. Саме тому ми вважаємо безпідставним невизнання предикатними злочинами кримінальні правопорушення, відповідальність за які передбачена ст. 212 та ст. 212-1 КК України.

Що стосується решти діянь, виключених 3 кола предикатних злочинів, зазначимо, що частину національного законодавства складають такі міжнародні акти як: Конвенція про відмивання, пошук, арешт та конфіскацію доходів, одержаних злочинним шляхом [8], Конвенція Ради Европи про відмивання, пошук, арешт та конфіскацію доходів, одержаних злочинним шляхом, та про фінансування тероризму [9], ратифікована Верховною Радою України [10], аналіз яких дає можливість дійти висновку, що нормативні положення зазначених документів складають головну джерельну базу впровадження світових стандартів у сфері боротьби 3 відмиванням «брудних» доходів та фінансування тероризму, котрі спрямовані на попередження, недопущення й припинення використання фінансових систем світу для відмивання таких доходів у межах взятих Україною на себе міжнародних зобов'язань.

Саме в положеннях цих нормативних актів, вважаємо цілком правильно, визначено єдиний підхід до визначення поняття «предикатний злочин», який означає саме будь-який злочин, у результаті якого виникли доходи, що можуть стати предметом злочину, зазначених у статтях иих Конвенцій (Злочин 3 відмивання грошей). 


\section{Кримінальне право, кримінальний процес та криміналістика}

У цьому контексті слід також відзначити Постанову Пленуму Верховного Суду України [11], яка винесена була саме $з$ метою правильного й однакового застосування судами законодавства про відповідальність за легалізацію (відмивання) доходів, одержаних злочинним шляхом, та у зв'язку 3 питаннями, що виникали у судовій практиці під час розгляду цієї категорії справ, положення якої, на наше переконання, не втратили своєї актуальності в силу того, що нею було визначено саме загальні підходи до розуміння категорії предикатного злочину. По-перше, цією постановою роз'яснено, що таким злочином може бути діяння, яке згідно з Кримінальним кодексом є злочином і за яке відповідною статтею (частиною статті) цього Кодексу передбачено покарання у виді позбавлення волі на строк не менше трьох років [11], 3 чим ми цілком погоджуємось, адже санкція статті 209 КК України передбачає як мінімальне покарання - позбавлення волі на строк від трьох років. По-друге, діяння, яке визначається злочином згідно з кримінальним законодавством іншої держави, якщо й КК України за таке саме діяння передбачена кримінальна відповідальність у виді позбавлення волі на строк не менше трьох років [11], з чим ми також згодні, адже вказане цілком відповідає законодавчим положенням про підстави кримінальної відповідальності (ст. 2 ККУ) та законодавству України про кримінальну відповідальність (ст. 3 ККУ).

Як підтвердження правильності отриманих результатів аналізу, слід вказати, що саме такий підхід був реалізований із прийняттям Закону України «Про запобігання та протидію легалізації (відмиванню) доходів, одержаних злочинним шляхом, фінансуванню тероризму та фінансуванню розповсюдження зброї масового знищення» [12], який діяв до прийняття нової редакції Закону від 06.12.2019 № 361-IX [13], саме положеннями якого було впроваджено нові стандарти FATF, які у порівнянні з попередніми Рекомендаціями [14] посилили вимоги до національних систем протидії відмиванню коштів та фінансуванню тероризму.
Досліджуючи цю проблематику, M.I. Бадзан в цілому підкреслив, що вказаними законодавчими змінами було розширено перелік предикатних злочинів [15]. Погоджуючись з цим, слід додати, що впровадження міжнародних положень щодо визначення категорії «предикатний злочин» дозволили відійти від раніше чинного дискусійного положення щодо обмеження кола діянь як джерела злочинного способу отримання майна.

Незважаючи на те, що чинні редакції ст. 209 КК України, а також Закону України «Про запобігання та протидію легалізації (відмиванню) доходів, одержаних злочинним шляхом, фінансуванню тероризму та фінансуванню розповсюдженню зброї масового знищення» [16] не дають законодавчого визначення поняття «предикатний злочин», чинна редакція складу злочину «легалізація (відмивання) майна, одержаного злочинним шляхом» не містить жодного посилання на будь-які винятки із загальної юридичної конструкції предикатного кримінального правопорушення.

Вбачаємо за можливе зазначити, що кримінальні правопорушення у сфері господарської діяльності, як правило, є основними джерелами злочинного походження майна. Утім, особливості реалізації державної політики щодо гуманізації відповідальності в цій сфері [17] спонукають звернути увагу на ті з них, котрі пов'язані з переміщенням через митний кордон України поза митним контролем або 3 приховуванням від нього певних предметів, насамперед визначених родовими ознаками у положеннях ст. 201КК України. Справа в тому, що iз набуттям чинності Закону України від 15.11.2011 № 4025-VI відбулася частокова декриміналізація такого предмета контрабанди, як товар.

Г.В. Галочка вважає, що зазначена часткова декриміналізація діяння, передбаченого ст. 201 КК України, суттєво спростила процедуру притягнення до відповідальності винних осіб та конфіскації предметів правопорушення в дохід держави [18]. Вважаємо, що з таким висновком можливо погодитися лише частково. 3 одного боку, декриміналізація «товарної» контрабанди, 
на наш погляд, дійсно можна розглядати як дієвий інструмент достатньо швидкого наповнення Державного бюджету від надходжень з реалізації предметів правопорушення за результатами розгляду судами в адміністративному порядку протоколів про порушення митних правил порушень (ст. 482 МК України) [19].

Однак, 3 іншого боку, теза науковця про спрощення процедури притягнення винних осіб за вчинення таких дій до відповідальності є достатньо дискусійною 3 кількох причин.

По-перше, адміністративну відповідальність не можна вважати тотожною кримінальній з огляду на ступінь негативних наслідків, які винна особа зобов'язана понести за вчинені умисні дії, заборонені законом.

По-друге, здійснення кримінального судочинства передбачає втілення державної політики у сфері суспільних відносин щодо забезпечення охорони прав і свобод людини і громадянина, власності, громадського порядку та громадської безпеки, довкілля, конституційного устрою України від кримінально-протиправних посягань (ст. 1) [20]. Саме для забезпечення реалізації цього завдання вітчизняне кримінальне законодавство визначає, які суспільно небезпечні дії $\mathrm{\epsilon}$ кримінальними правопорушеннями (злочинами). Адміністративне ж судочинство покликане реалізовувати таку державну політику щодо правопорушень, які за своїм характером не тягнуть за собою відповідальність відповідно до КК України (ст. 9 КУпАП) [21], інакше кажучи, протиправних діянь, рівень суспільної небезпеки яких менший.

По-третє, критика строків досудового розслідування, яка власне і стала рушійною силою для прийняття рішення щодо декриміналізації «товарної контрабанди», на наше переконання, не в повній мірі врахує комплексний характер завдань кримінального судочинства щодо забезпечення швидкого, повного та неупередженого розслідування і судового розгляду кримінальних проваджень 3 тим, щоб кожний, хто вчинив кримінальне правопорушення, був притягнутий до відповідальності в міру своєї вини, жоден невинуватий не був обвинувачений або засуджений, жодна особа не була піддана необгрунтованому процесуальному примусу і щоб до кожного учасника кримінального провадження була застосована належна правова процедура (ст. 2) [22]. Завдання провадження у справах про адміністративні правопорушення дещо схожі і полягають у своєчасному, всебічному, повному і об'єктивному з'ясуванні обставин кожної справи, вирішенні ії в точній відповідності з законом, забезпеченні виконання винесеної постанови, а також виявленні причин та умов, що сприяють вчиненню адміністративних правопорушень, запобіганні правопорушенням, вихованні громадян у дусі додержання законів, зміцнення законності (ст. 245 КУпАП) [23]. Однак санкція статті ст. 482 МК України, як і інших правопорушень, визначених Главою 68 МК України, передбачає лише накладення штрафу, конфіскацію товарів, безпосередніх предметів порушення митних правил та лишає поза увагою заходи дієвого впливу на осіб, які вчинили суспільно небезпечну дію, обов'язок зазнати негативні наслідки, які відповідали б рівню суспільної небезпеки та в міру своєї вини. B.В. Кухар, предметно досліджуючи цю проблематику цілком слушно вказав, що негативними наслідками декриміналізації діяння щодо переміщення товарів через кордон призвели, з одного боку, до збільшення чисельності та активації угруповань та окремих осіб, які спеціалізуються на цьому виді протиправної діяльності, а з іншого - до зниження рівня протидії зазначеним діянням, оскільки проведення оперативнорозшукової діяльності в такому разі Законом заборонено [24]. Підтримуючи висновки автора, вважаємо, що заходи кримінально правового впливу відповідатимуть рівню суспільної небезпеки вищевказаного діяння та сприятимуть підвищенню результативності в протидії цьому негативному явищу.

По-четверте, загальновідомим є те, що саме рівень суспільної небезпеки є тим критерієм оцінки протиправних дій для їх розмежування за видами відповідальності. Зважаючи на те, що рівень суспільної небезпе- 


\section{Кримінальне право, кримінальний процес та криміналістика}

ки т.зв. «товарної» контрабанди лишається достатньо високим, а в основу законодавчої ініціативи іiі декриміналізації було покладено державно-політичне рішення щодо забезпечення можливості отримання позитивного економічного ефекту від додаткових грошових надходжень до Державного бюджету України в межах заходів із гуманізації відповідальності за правопорушення у сфері господарської діяльності, на хибність чого у своєму дослідженні також вказав В.В. Кухар, який у своєму науковому доробку врахував також і іноземний досвід країн EC [24].

Розгляд цього питання в межах нашого предмету дослідження, а також отримані результати дають підстави говорити про доцільність відновлення кримінальної відповідальності за вищевказане діяння, наразі, $з$ урахуванням рівня суспільної небезпечності воно не належить до категорії предикатних злочинів лише з формальних підстав, адже саме кримінальні правопорушення можуть розглядатися в межах даної дефініції.

Продовжуючи розгляд питання щодо віднесення кримінальних правопорушень до категорії предикатних злочинів, пов'язаних 3 отриманням економічної вигоди, інакше кажучи, вчинення яких є або може стати джерелом незаконного отримання майна, беручи за основу саме цей критерії розподілу, в першу чергу, до його кола ми відносимо наступні злочинні діяння, не відступаючи від законодавчого підходу їх класифікації за родовим об'єктом:

1) кримінальні правопорушення проти власності (Розділ VI ККУ);

2) кримінальні правопорушення у сфері службової діяльності та професійної діяльності, пов'язаної з наданням публічних послуг (Розділ XVII ККУ);

3) кримінальні правопорушення проти основ національної безпеки України (Розділ I ККУ), зокрема: «Фінансування дій, вчинених 3 метою насильницької зміни чи повалення конституційного ладу або захоплення державної влади, зміни меж території або державного кордону України» (ст. 110-2 ККУ);
4) кримінальні правопорушення у сфері господарської діяльності (Розділ VII ККУ);

5) кримінальні правопорушення проти громадської безпеки (Розділ IX ККУ), зокрема: «Створення, керівництво злочинною спільнотою або злочинною організацією, а також участь у ній» (ст. 255 ККУ), «Встановлення або поширення злочинного впливу» (ст. 255-1 ККУ), «Сприяння учасникам злочинних організацій та укриття їх злочинної діяльності» (ст. 256 ККУ), «Бандитизм» (ст. 257 ККУ), «Терористичний акт» (ст. 258 ККУ), «Створення терористичної групи чи терористичної організації» (ст. 258-3 ККУ), «Сприяння терористичному акту» (ст. 258-4 ККУ), «Фінансування тероризму» (ст. 258-5 ККУ) та ін.;

6) кримінальні правопорушення у сфері обігу наркотичних засобів, психотропних речовин, їх аналогів або прекурсорів (Розділ XIII ККУ), а саме: «Контрабанда наркотичних засобів, психотропних речовин, їх аналогів чи прекурсорів або фальсифікованих лікарських засобів» (ст. 305 ККУ), «Незаконне виробництво, виготовлення, придбання, зберігання, перевезення, пересилання чи збут наркотичних засобів, психотропних речовин або їх аналогів» (ст. 307 ККУ), «Викрадення, привласнення, вимагання прекурсорів або заволодіння ними шляхом шахрайства або зловживання службовим становищем» (ст. 312 ККУ), «Викрадення, привласнення, вимагання обладнання, призначеного для виготовлення наркотичних засобів, психотропних речовин або їх аналогів, чи заволодіння ним шляхом шахрайства або зловживання службовим становищем та інші незаконні дії з таким обладнанням» (ст. 313 ККУ), «Незаконне виготовлення, підроблення, використання чи збут підроблених документів на отримання наркотичних засобів, психотропних речовин або прекурсорів» (ст. 318 ККУ), «Порушення встановлених правил обігу наркотичних засобів, психотропних речовин, їх аналогів або прекурсорів» (ст. 320 ККУ), «Незаконне виробництво, виготовлення, придбання, перевезення, пересилання, зберігання $з$ метою збуту або збут отруйних чи сильнодіючих речовин або отруй- 
них чи сильнодіючих лікарських засобів» (ст. 321 ККУ), «Фальсифікація лікарських засобів або обіг фальсифікованих лікарських засобів» (ст. 321-1).

Не вдаючись до загальної кримінальноправової оцінки перерахованих кримінальних правопорушень, з огляду на предмет нашого дослідження зазначимо лише те, що згрупувати їх за даним критерієм розподілу, а також викласти дані в такому порядку стало можливим, зважаючи на отримані результати опитування, а також на пряму вказівку закону на можливість збуту як складової об'єктивної сторони злочину, а також сутнісна їх характеристика, яка передбачає корисливий мотив та можливість отримання злочинної економічної вигоди як суспільно небезпечний наслідок вчинення таких діянь.

Застосовуючи аналогічний підхід умовного групування до їх кола можуть бути віднесені і інші злочинні дій, родовим об'єктом посягання яких є: основи національної безпеки (Розділ І ККУ), життя та здоров' я особи (Розділ ІІ ККУ), воля, честь та гідність (Розділ III ККУ), виборчі, трудові та інші особистісні права і свободи людини і громадянина (Розділ V ККУ), довкілля (Розділ VIII ККУ), безпека руху та експлуатація транспорту (Розділ XI ККУ), сфера охорони державної таємниці та недоторканість державних кордонів (Розділ XIV ККУ), авторитет органів державної влади, органів місцевого самоврядування (Розділ XV ККУ), сфера використання комп'ютерів, систем та комп'ютерних мереж і мереж електрозв'язку (Розділ XVI ККУ), правосуддя (Розділ XVIII ККУ), встановлений порядок несення військової служби (Розділ XIX ККУ), мир, безпека людства та міжнародний правопорядок (Розділ ХХ ККУ).

Зазначимо також, що отримані результати анкетування дали можливість визначити, що за безпосереднім об'єктом злочинного посягання, вищевказаний перелік може бути доповнений кримінальними правопорушеннями, пов'язаними і 3 незаконним обігом зброї, наприклад, контрабанда зброї (ст. 201 ККУ), фінансування не передбачених законом воєнізованих або збройних формувань, постачання їм зброї, боєприпасів, вибухових речовин чи військової техніки» (ч. 3 ст. 260 ККУ) тощо. Зважаючи на те, що чинний КК України не визначає його як окремий родовий об'єкт злочинного діяння, тому групу цих кримінальних правопорушень ми розглядаємо відокремлено умовно. Разом з цим, наукове дослідження питання доцільності внесення відповідних змін до кримінального законодавства виходить за межі предмету нашого дослідження.

Отримані результати, на нашу думку, дають можливість з'ясувати, які саме злочинні діяння зумовлюють отримання незаконної економічної вигоди у формі певного майна. Тому дії з подальшого імітування законності джерел походження таких активів й подальше використання в цивільно-правових відносинах необхідно кваліфікувати за ст. 209 КК України.

3'ясовуючи питання про можливості віднесення до категорії «предикатний злочин» або «предикатне кримінальне правопорушення», які ми у своєму дослідженні ми розглядаємо як тотожні, інших злочинних діянь, юридична техніка закріплення яких у кримінальному законодавстві передбачає використання конструкцію предикатного діяння (наприклад п. 9 ч. 2 ст. 115 ККУ), варто зазначити наступне.

Редакція диспозиції ст. 209 КК України містить пряму вказівку на конкретний предмет злочину, під яким у теорії кримінального права розуміють «будь-які речі матеріального світу, із певними властивостями яких кримінальний закон пов'язує наявність у діях особи конкретного злочину» [25]. Саме такі властивості й визначатимуть його фізичні (майно) та юридичні ознаки (злочинний спосіб його отримання) [7, с. 53].

Ми вбачаємо за можливе погодитись із вищевказаним, а тому слід дійти висновку, що фактична відсутність, по-перше, дій, спрямованих за метою на незаконне отримання економічної вигоди, а по-друге, ознак у закріплених конструкціях предикатних діянь у диспозиціях статей КК України, не дозволяє розглядати такі кримінальні правопорушення як предикатні. 


\section{Кримінальне право, кримінальний процес та криміналістика}

Достатньо великий перелік визначеного нами кола предикатних кримінальних правопорушень спонукає до їх класифікації для зручності в подальшому науковому дослідженні.

Отримані результати аналізу дають можливість формалізувати їх види за наступними критеріями розподілу:

- за зв'язком предикатного кримінального правопорушення з основним складом злочинноі дї: злочинні діяння, спрямовані на виникнення незаконного майна (наприклад ст.ст. 201, 204, 257, 258, ч. 3 ст. 267-1, Розділ XVII ККУ та ін.); ті, які описують предмет злочину (наприклад ст. 198 ККУ);

- за зв'яком суспільно небезпечного наслідку вчиненого кримінального правопорушення 3 виникненням майна, шо може стати предметом злочину: предикатні кримінальні правопорушення (наприклад, ст. 258-4 , Розділ XVII ККУ та ін.) та злочини з предикатною конструкцією об'єктивної сторони складу злочину (наприклад, п. 9 ч. 2 ст. 115, ст.ст. 345, 345-1, 350 ККУ та ін.);

- за об'єктом кримінального правопорушення: злочинні діяння, які посягають на соціальні цінності (родовий об'єкт) (наприклад, ст. 110-2, 201, 305 ККУ та ін.) та ті, що посягають на соціальні цінності, визначені індивідуальними ознаками (безпосередній об'єкт) (наприклад, ч. 3 ст. 260 ККУ та ін.);

- за спрямованістю злочинного умислу: кримінальні правопорушення 3 корисливою метою (наприклад, Розділи VII, XVII ККУ та ін.) та ті, які спрямовані на приховування інших злочинних дій або полегшення його вчинення (наприклад, п. 9 ч. 2 ст. 115 ККУ);

- за ступенем зв'язку з предметом кримінального правопорушення: ті, які описують предмет злочинного діяння (наприклад, ст.ст. 198, 204, 307 ККУ та ін.), а також злочинні діяння, які характеризують рівень його суспільної небезпеки (наприклад, ч. 3 ст. 267-1, ч. 2 ст. 310 , ч.2 ст. 311 ККУ та ін).

\section{Висновки}

Проведеним дослідженням 3'ясовано, що Кримінальний кодекс України закріплюе склади кримінальних правопорушень, об'єктивна сторона вчинення яких передбачає посилання на конструкцію предикатного діяння. 3 точки зору нормативно закріплених підходів у вітчизняному кримінальному законодавстві, дефініція «предикатне кримінальне правопорушення» охоплює відносну частину 3 їх сукупності, яка закріплена саме у кримінальному законодавстві держави. Інші суспільно небезпечні дії можуть бути віднесені до категорії предикатних кримінальних правопорушень лише після криміналізації таких діянь.

Згідно 3 визначеним вітчизняним законом про кримінальну відповідальність групування злочинних діянь, предикатні кримінальні правопорушення можуть бути розмежовані за родовим та безпосереднім об'єктом злочинного посягання. Згідно з авторським підходом до їх класифікації, до їх кола не відноситимуться злочини 3 предикатною конструкцією об'єктивної сторони складу злочину, а також ті, котрі спрямовані на приховування інших злочинних дій або полегшення його вчинення. В основі відмежування злочинних діянь від категорії «предикатне кримінальне правопорушення» лежить відсутність обов'язкових ознак предмету злочинного діяння, а саме: речі матеріального світу, із властивостями яких КК України пов'язує наявність у діях особи конкретного складу кримінального правопорушення. Зазначене положення пов'язано також і 3 фактичною відсутністю дій, спрямованих за метою на незаконне отримання економічної вигоди, а також посилань на необхідні ознаки у закріплених конструкціях предикатних діянь.

\section{Аітература}

1. Ашин Д.А. Ретроспективный анализ конструкции предикатных преступлений в уголовном праве России. / Д.А. Ашин // Актуальные проблемы Российского права. - 2009. № 4. - С. 250-261.

2. Ашин Д.А. Виды предиктных преступлений в уголовном прав России // Актуальные проблемы российского права. 2010. № 3. - С. 251-261.

3. Науково-практичний коментар Кримінального кодексу України / за 
ред. М.I. Мельника, М.I. Ховранюка. - 9-те вид. переробл. та допов. - К. : Юридична думка, 2012. - 1316 с.

4. Науково-практичний коментар Кримінального кодексу України - [Електронний ресурс]. - Режим доступу: http:// yurist-online.com/ukr/uslugi/yuristam/ kodeks/024/206.php.

5. Про внесення змін до Закону України «Про запобігання та протидію легалізації (відмиванню) доходів, одержаних злочинним шляхом»: Закон України від 18.05.2010 № 2258-VI - [Електронний ресурс]. - Режим доступу: https://zakon.rada. gov.ua/laws/card/2258-17 (втратив чинність).

6. Кримінальне право України: Особлива частина : підручник / Ю.В. Баулін, B.I. Борисов, В.І. Тютюгін та ін. ; за ред. В.В. Сташиса, В.Я. Тація. - 4-те вид., переробл. і допов. - Х. : Право, 2010. - 608 с.

7. Чаричанський О.О. Підстави кримінальної відповідальності за легалізацію (відмивання) доходів, одерджаних злочинним шляхом, за Кримінальним кодексом України : дис. канд. юр. наук : 12.00.08 / . - Харків, 2004. - 205 с.

8. Конвенція про відмивання, пошук, арешт та конфіскацію доходів, одержаних злочинним шляхом Конвенція, Міжнародний документ від 08.11.1990, ідентифікатор 995_029 - [Електронний ресурс]. - Режим доступу: https://zakon.rada.gov.ua/laws/ card/995 029.

9. Конвенція Ради Европи про відмивання, пошук, арешт та конфіскацію доходів, одержаних злочинним шляхом, та про фінансування тероризму : Конвенція, Міжнародний документ від 16.05.2005, ідентифікатор 994_948 - [Електронний ресурс]. - Режим доступу: https://zakon.rada.gov.ua/ laws/card/994 948.

10. Про ратифікацію Конвенції Ради Европи про відмивання, пошук, арешт та конфіскацію доходів, одержаних злочинним шляхом, та про фінансування тероризму : Закон України від 17.11.2010 № 2698-VI (sз змінами, внесеними згідно із Законом № 361-IX (361-20) від 06.12.2019) - [Електронний ресурс]. - Режим доступу: https:// zakon.rada.gov.ua/laws/show/2698-17\#Text/.
11. Про практику застосування судами законодавства про кримінальну відповідальність за легалізацію (відмивання) доходів, одержаних злочинним шляхом : Постанова Пленуму Верховного Суду України від 15.04.2005 № 5 - [Електронний ресурс]. - Режим доступу: https://zakon.rada.gov.ua/ laws/show/v0005700-05.

12. Про запобігання та протидію легалізації (відмиванню) доходів, одержаних злочинним шляхом, фінансуванню тероризму та фінансуванню розповсюдженню зброї масового знищення : Закон України від 14.10.2014 № 1702-VII - [Електронний pecypc]. - Режим доступу: https://zakon.rada. gov.ua/laws/show/1702-18\#Text.

13. Про запобігання та протидію легалізації (відмиванню) доходів, одержаних злочинним шляхом, фінансуванню тероризму та фінансуванню розповсюдженню зброї масового знищення : Закон України від 06.12.2019 № 361-IX - [Електронний ресурс]. - Режим доступу: https://zakon.rada. gov.ua/laws/show/361-20\#n880.

14. Про Сорок рекомендацій Групи 3 розробки фінансових заходів боротьби 3 відмиванням грошей (FATF) : Постанова Кабінету Міністрів України і Національного Банку України від 28.08.2011 № 1124. - [Електронний ресурс]. - Режим доступу: https://zakon.rada.gov.ua/laws/show/11242001-\%D0\%BF\#Text.

15. Бадзан M.I. Основні етапи формування національної системи боротьби з відмиванням злочинних доходів / М.I. Бадзан - [Електронний ресурс]. - Режим доступу: http://libfor.com/index.php?newsid $=1127$.

16. Про запобігання та протидію легалізації (відмиванню) доходів, одержаних злочинним шляхом, фінансуванню тероризму та фінансуванню розповсюдженню зброї масового знищення : Закон України від 06.12.2019 № 361-IX - [Електронний ресурс]. - Режим доступу: https://zakon.rada. gov.ua/laws/show/361-20\#n880.

17. Про внесення змін до деяких законодавчих актів України щодо гуманізації відповідальності за правопорушення у сфері господарської діяльності : Закон України від 15.11.2011 № 4025-VI - [Електронний 


\section{Кримінальне право, кримінальний процес та криміналістика}

peсурс]. - Режим доступу: https://zakon.rada. gov.ua/laws/show/4025-VI\#Text.

18. Галочка Г.В. Декриміналізація «товарної» контрабанди одне 3 основних завдань реформування діяльності митної служби України / Г.В. Галочка // Митна безпека. - 2010. - № 2. Серія «Право». -C. 51-54.

19. Митний кодекс Украъни : Закон України від 13.03.2012 № 4495-VI - [Електронний ресурс]. - Режим доступу: https:// zakon.rada.gov.ua/laws/show/4495-17\#Text.

20. Кримінальний кодекс України : Закон України від 05.04.2001 № 2341-III [Електронний ресурс]. - Режим доступу: https://zakon.rada.gov.ua/laws/show/2341-14/ ed20010405 (перша редакція - прийняття від 05.04.2001).

21. Кодекс України про адміністративні правопорушення (статті 1-212-24) : Закон України від 07.12.1984 № 8073-Х - [Електронний ресурс]. - Режим доступу: https:// zakon.rada.gov.ua/laws/show/80731-10\#n60.

22. Кримінальний процесуальний кодекс України : Закон України від 13.04.2012 № 4651-VI - [Електронний ресурс]. - Peжим доступу: https://zakon.rada.gov.ua/laws/ show/4651-17\#Text.

23. Кодекс України про адміністративні правопорушення (статті 213-330) : Закон України від 07.12.1984 № 8073-Х - [Електронний ресурс]. - Режим доступу: https:// zakon.rada.gov.ua/laws/show/80731-10\#n60.

24. Кухар В.В. Декриміналізація «товарної» контрабанди : теорія та практика / В.В. Кухар // Університетські наукові записки, 2013, № 3 (47) - с. 408-412.

25. Кримінальне право України: Загальна частина : Підручник / За заг. ред. М.І. Бажанова, В.В. Сташиса, В.Я. Тація. Харків: 1998. - С. 78

Недоліки функиіонування кримінальноправового регулювання суспільних відносин щодо притягнення до відповідальності за виинення кримінальних правопорушень у сфері господарської діяльності, а також інших такого роду суспільно небезпечних діянь, пов'язаних з легалізачією (відмиванням) майна, одержаного внаслідок злочинним шляхом, в достатній мірі ускладнюють діяльність компетентних органів з виконання завдань кримінального судочинства. Саме такий зв'язок легалізащиї (відмивання) майна з іншими предикатними кримінальними правопорушеннями значною мірою зумовлюе ї̈ суспільну небезпечність. Відповідно, наукове дослідження сукупності таких діянь вимагає пошуку підходів до їх типізациї для напрацювання пропозицій для нормативного закріплення категорії «предикатний злочин» у вітчизняному кримінальному законодавстві.

Метою статmi є вироблення наукового обгрунтування до визначення кола предикатних кримінальних правопорушень, а також підходу до їх класифікаиіӥ.

Наукова новизна дослідження пов'язана iз подальшим розвитком наукової думки щодо дебініціӥ «предикатне кримінальне правопорушення» та типізациї діянь, віднесених до ияієі категоріi.

На підставі критичного аналізу норм вітчизняного кримінального законодавства набули розвитку нормативно-правові положення щодо злочинних діянь у сфері господарської діяльності. Сформовано авторсъке бачення до наукового доробку в иій сбері, а також щодо визначення кола предикатних кримінальних правопорушень, критерїв їх розмежування на види, у тому иислі й щодо відмежування предикатних злочинів від інших протиправних дій.

Висновки. Підсумовуючи, зазначимо, щзо сучасні світові підходи з питань регулювання суспільних відносин з притягнення до кримінальної відповідальності за легалізацію (відмивання) майна, одержаного злочинним иляхом, у зв'язку із внесенням відповідних змін до вітчизняного законодавства в иій сбері, вплинули на зміну раніше наявних підходів як до тлумачення самої категорї «предикатний злочин», так $i$ визначення кола кримінальних правопорушень, які можуть бути віднесені до изіё деббініщї. Однак питання класифікаџіӥ таких діянь поки що не знайшло достатнъого висвітлення в сучасному науковому доробку.

Подальше вдосконалення вітчизняного кримінального законодавства в иій сфері має враховувати чинний Кримінальний кодекс Украӥни, закріплювати достатнъо велику кількість складів кримінальних правопорушень, об'єктивна сторона вчинення яких передбачає посилання 
на конструкиію предикатного діяння. 3 точки зору нормативно закріплених підходів у вітчизняному кримінальному законодавстві, дебініиія «предикатне кримінальне правопорушення» охоплюе лише відносну частину з їх сукупності, за умови їх криміналізащї. Предикатні кримінальні правопорушення можуть бути розмежовані за родовим та безпосереднім об'єктом злочинного посягання. Авторсъкий підхід до їх класифікащї грунтується на співвідношенні бізичних $i$ юридичних ознак предмету злочину за cm. 209 КК України зі складами інших кримінальних правопорушень, які або закріплюють конструкиію предикатного діяння у диспозищї статті КК Украӥни, або ж спрямовані на незаконне отримання економічної вигоди.

Ключові слова: предикатний злочин, легалізачія (відмивання) майна, суспільно небезпечні дї, види, класифікачія.

\section{TYPES OF PREDICATE CRIMES IN THE DOMESTIC IN GRIMINAL LEGISLATION}

Disadvantages of the functioning of criminal law regulation of public relations to prosecute for criminal offenses in the field of economic activity, as well as other such socially dangerous acts related to the legalization (laundering) of property obtained as a result of criminal proceedings, sufficiently complicate activities competent authorities for the performance of criminal proceedings. It is this connection of legalization (laundering) of property with other predicate criminal offenses that largely determines its social danger. Accordingly, the scientific study of the totality of such acts requires the search for approaches to their typification for developing proposals for the normative consolidation of the category of "predicate crime» in the domestic criminal law.

The purpose of the article is to develop a scientific justification for determining the range of predicate criminal offenses, as well as an approach to their classification.
The scientific novelty of the study is related to the further development of scientific thought on the definition of "predicate criminal offense» and the typification of acts belonging to this category.

Moreover the normative-legal provisions concerning criminal acts in the field of economic activity have been developed based on the basis of the critical analysis of norms of the domestic criminal legislation. The author's vision to the scientific achievements in this area has been formed, as well as to determine the range of predicate criminal offenses, the criteria for their differentiation into types, including the separation of predicate crimes from other illegal actions.

Conclusions. Summing up, we note that modern global approaches to the regulation of public relations to prosecute for legalization (laundering) of property obtained by criminal means, in connection with the relevant changes in domestic legislation in this area, have influenced the change of existing approaches as to the interpretation of the category of "predicate crime» and the definition of the range of criminal offenses that can be attributed to this definition. However, the question of classification of such acts has not yet found sufficient coverage in the existing scientific achievements.

Further improvement of domestic criminal legislation in this area should take into account the current Criminal Code of Ukraine establishes a large number of criminal offenses, the objective side of which involves reference to the construction of the predicate act. From the point of view of normatively fixed approaches in the domestic criminal legislation, the definition of "predicate criminal offense» covers only a relative part of their totality if they are criminalized. Predicate criminal offenses can be distinguished by generic and direct object of criminal encroachment. The author's approach to their classification is based on the ratio of physical and legal characteristics of the subject of the crime under Art. 209 of the Criminal Code of Ukraine with the composition of other criminal offenses, which either enshrine the construction of the predicate act in the disposition of the article of the Criminal Code of Ukraine or are aimed at illegally obtaining economic benefits.

Key words: predicate crime, legalization (laundering) of property, socially dangerous actions, types, classification. 


\title{
МЕТОДОЛОГІЯ ДОСЛІДЖЕННЯ КРИМІНАЛЬНИХ ПРОСТУПКІВ
}

\author{
АЛЕКСЕСВА-ДАНИЛЕНКО Юлія Володимирівна - аспірант Харківського \\ національного університету внутрішніх справ \\ DOI 10.32782/LAW.2020.3.18
}

\section{Постановка проблеми}

Сучасне українське правознавство розвивається під впливом радикальних реформ, докорінних перебудов українського суспільства. Впровадження інституту кримінальних проступків є одним із напрямів реформування кримінального законодавства України. Змінами до Кримінального Кодексу України стосовно кримінальних проступків запроваджено нове кримінально-правове регулювання значної частини кримінальних правопорушень, відповідальність за які не тягне позбавлення волі.

Класифікація кримінальних правопорушень змінилася на: а) кримінальні проступки; б) злочин невеликої тяжкості; в) тяжкі злочини; г) особливо тяжкі злочини, що обумовлює необхідність додаткового вивчення їх класифікацій та удосконалення методології їх дослідження.

Метою статті є аналіз методології дослідження правових ознак кримінальних проступків.

Стан наукової розробленості теми дослідження

Методологію дослідження як наукове пізнання розглядали М. Кельман і I. Ковалов у статті «Методологія дослідження як наука пізнання», І.А. Міщенко в статті «Методологія дослідження в контексті дисертаційних і дипломних робіт з економіки»,А. Благодарний у статті «Методологія дослідження правової регламентації», П.Ю Саух -
«Основи методології та організації наукових досліджень» та інші.

На монографічному рівні методологія дослідження кримінально-правових явищ представлена в працях А.М. Васильєва, М.I. Козюбри, П.М. Рабіновича, О.М. Аитвинова, В.Б Харченко, Р.С. Веприцького, I.О. Бандурки.

\section{Виклад основного матеріалу}

Методологія дослідження кримінального правопорушення здійснюється 3 метою правової оцінки діяння та поділу злочинів на певні групи, залежно від передбачених у кримінальному законодавстві ознак, які впливають на покарання особи, визнаною винною у вчиненні кримінального правопорушення.

Методологія (гр. «mothodos» - спосіб, метод i logos - наука, знання) дослідження кримінальних проступків $є$ сукупністю методів дослідження, що застосовується при вивченні причин і умов кримінальних проступків, причинного зв'язку вчинення проступку 3 його наслідками, ознак класифікацій кримінального проступку, розроблення заходів запобігання кримінальних проступків.

В основі дослідження кримінальних проступків лежить, на думку автора, структурно-функціональний метод, який полягає у виділенні в складі досліджуваного кримінального правопорушення структурних елементів, а саме: суб'єкта посягання, об'єкт посягання, суб'єктивної і об'єктивної сторін проступку та залежність між ними. Кожний 
елемент складу кримінального проступку виконує свої специфічні функції, які в тій чи іншій мірі характеризують кримінальний проступок у цілому.

Системно-діяльний метод створює можливість комплексно дослідити будь-яку сферу людської діяльності, у т.ч. протиправну антисуспільну діяльність.

Людську діяльність розділяють на окремі компоненти, серед яких найбільш суб'єктивними будуть: потреба, суб'єкт, об'єкт, умови, процес, зв'язок, результат.

При дослідженні кримінальних проступків важливо виявити умови і причини, які спонукали особу на вчинення кримінального правопорушення, спосіб іï життедіяльності, вплив навколишнього середовища та інші обставини.

Системно-генетичний метод дозволить прослідкувати весь процес зародження, розвиток і вчинення протиправного діяння, 3окрема, кримінального проступку.

Статичний метод доцільним буде при вивченні всієї сукупності кримінальних проступків у цілому в Україні, в окремих містах чи в областях, на територіях об'єднаних територіальних громад, а порівняльно-правовий метод дозволить дослідити кримінальні проступки у порівнянні 3 іншими видами кримінальних правопорушень за різні періоди часу в різних регіонах.

Історико-порівняльний метод дослідження кримінальних проступків передбачає вивчення цього правового явища в хронологічній послідовності. За допомогою цього методу шляхом порівняння виявляють окремі етапи розвитку правового регулювання кримінальних проступків, виявляють загальні і особливі ознаки цих подібностей та відмінностей, зміни, що відбулися, зіставляють різні рівні розвитку досліджуваного об'єкта, визначають тенденції розвитку інституту кримінальних проступків.

Кримінальний проступок, як кримінально-правове явище, було передбачено в Кримінальному-процесуальному кодексі України, який прийнятий у 2013 році, «Закон України про кримінальні проступки» був введений в дію 1 липня 2020 року. 3 моменту впровадження кримінального проступку, як кримінально-караного діяння, застосування його, як кримінального правопорушення в дію, пройшло сім років, впродовж яких на тему кримінальних проступків було опубліковано багато наукових статей та видано кілька нормативних актів, але після впровадження кримінальних проступків у правове русло, їх дослідження фактично припинилось.

При дослідженні окремих кримінальних проступків, як кримінальних правопорушень у сфері підприємства, господарськофінансової діяльності, особливого значення набувають метода аналізу документальної інформації (банківські рахунки, заяви, договори, протоколи засідань тендерних комітетів, чеки на оплату та інші документи).

Досліджуючи письмові документи доцільно використовувати і метод контентаналізу, який передбачає збирання кількісних даних про кримінальні проступки, які містяться у документах, у юридичних звітах і повідомленнях, у наукових джерелах, у засобах масової інформації.

Серед методів дослідження кримінальних проступків вирізняються методи опитування, які мають усну та писемну форму.

Опитування може здійснюватися серед потерпілих від кримінальних проступків, серед осіб, які їх вчинили, опитування інших осіб, посадових осіб, уповноважених здійснювати кримінальні провадження.

Опитування може здійснюватися за довільною схемою або за структурованою анкетною формою. Опитування може мати різні завдання: кримінологічні, з метою зібрання інформацій про певні види кримінальних проступків, або їх виконавців, для отримання статистичної інформації, або отримання інформації про конкретні обставини вчинення кримінальних проступків.

Методологія дослідження кримінальних проступків допускає застосування і інших методів дослідження як спосіб пізнання , дослідження явища правового характеру. Серед методів дослідження кримінальних проступків особливе місце займає метод критичного аналізу статистичних даних, інформації і відомостей про різні види кримінальних проваджень, узагальнення практичного досвіду, наукової і методичної літератури з питань кримінальних проступків. 


\section{АНОТАЦІЯ}

у статті розглянуто поняття та зміст методологї дослідження та зміст кримінальних проступків як кримінальних правопорушень. Визначено цілі і мету дослідження причин $i$ умов вчинення кримінальних проступків, охарактеризовані основні методи дослідження, Вказано, шо методологія дослідження кримінальних проступків-це сукупність методів, способів та дій наукового пізнання інституту кримінальних проступків як протиправного явища. Кожний метод застосовувати відповідно до поставленої мети дослідження. Методи дозволяють отримати якісні показники стосовно об'єкта дослідження.

Ключові слова: кримінальні проступки, методологія, дослідження, методи, наслідки, законодавство, діяльність.

У правознавстві при вивченні кримінальних явищ, зокрема кримінальних проступків, доцільно використовувати і математичні методи, які дають можливість вивчити масові явища правового характеру в їх кількісному і якісному вираженні.

Метод дослідження не $\epsilon$ щось підсуб'єктивне, кожний метод реалізується певним суб'єктом: ученим-кримінологом, прокурором, суддею чи іншим суб'єктом права. Будь-який метод $є$ засобом досягнення мети дослідження і вибір методу залежить від мети дослідження, а сутність методу, насамперед, змістом об'єкта, предметом дослідження.

Методологія дослідження кримінальних проступків забезпечує пізнання правових відносин які виникають у процесі реалізацій кримінального законодавства, стосовно тих кримінальних правопорушень, які мають ознаки кримінальних проступків. Методологія прагне дати відповідь на ті питання, що обумовлені вчиненням кримінальних проступків, а саме на причини і умови, характер, класифікацію об'єкта і суб'єкта проступку, причинний зв'язок між діянням і наслідками.

\section{Висновки}

При науковому дослідженні кримінальних проступків, як кримінальних протиправних явищ, важливо все, які причини

\section{SUMMARY}

The article considers the notion and content of the research methodology and the content of criminal delicts as criminal proceedings. The objectives and aim of investigating the reasons and conditions of committing criminal delicts are determined, the main methods of research are characterized. It is proved that the methodology of researching criminal delicts is a combination of methods, means, and acts, scientific cognition of the criminal delicts institution as an illegal phenomenon Each method is applied according to the set aim of the research The methods allow obtaining high quality performance related to the object of research.

і умови, як сприяли їх вчиненню, дані про суб'єктів проступків, об'єкта кримінального посягання та їх наслідки. 3 метою дослідження використовуються різні методи, зокрема, структурно-функціональний, системно-генетичний, порівняльно- історичний, статистичний метод та метод аналізу документальної інформації, метод опитування та інші. Накопичення наукових фактів, здобутих у процесі дослідження та результати дослідження дають можливість розробити заходи, протидії вчинення кримінальних проступків, усунення причин і умов їх звершення, удосконалення їх правового регулювання.

\section{入ітература}

1. Кельман М., Коваль І. Методологія досліджень як наукове пізнання. - Аьвів. 2015. - C. 203 (199-204 c.).

2. Метод у широкому значенні слова// http://politics.org.ua/pages-1109.html.

3. Кримінальний процесуальний кодекс України// Відомості Верховної Ради України, 2013. - № 9-10, 11-12, № 13. Ст. 88.

4. Про внесення змін до деяких законодавчих актів; Про внесення змін до деяких законодавчих актів України у зв'язку 3 прийняттям Закону України «Про внесення змін до деяких законодавчих актів України щодо спрощення досудового розслідування окремих категорій кримінальних проваджень: Закон України. - 2020. № 17. - Ст. 76. 


\title{
ЗАРУБІЖНИЙ ДОСВІД РЕГЛАМЕНТАЦІї КРИМІНАЛЬНОӤ ПРОЦЕСУАЛЬНОЇ ДІЯЛЬНОСТІ АДВОКАТА-ПРЕДСТАВНИКА ПОТЕРПЈЛГО
}

\author{
СМЕЛЬЯНОВ Роман Олександрович - викладач кафедри організації \\ досудового розслідування факультету № 1 Криворізького навчально-наукового \\ інституту Донецького юридичного інституту МВС України \\ УДК 343.121.4 \\ DOI 10.32782/LAW.2020.3.19
}

В умовах реформування кримінального процесуального провадження загалом та адвокатури, зокрема, пріоритетність захисту як правового інституту важко перебільшити, адже саме завдяки його реалізації забезпечується всебічний розвиток демократії, дотримання прав та свобод особи, рівноправність, змагальність, справедливе правосуддя та досягнення істини у справі. На сьогодні триває процес формування правового та організаційного забезпечення засади забезпечення права на захист, який є пріоритетним напрямком державної політики України.

В умовах побудови правової держави актуальною для науки кримінального процесу і практики законотворення є захист прав потерпілого, процесуальний статус якого в умовах чинного законодавства менш досконалий, ніж підозрюваного, обвинуваченого. Декларуючи те, що призначення кримінального процесуального законодавства, перш за все, полягає у захисті потерпілих від кримінального правопорушення, законодавець, е дійсності, на перше місце ставить захист інтересів підозрюваного та обвинуваченого.

Однак, на ефективне поновлення прав та законних інтересів осіб, потерпілих від злочину орієнтують і сучасні міжнародні документи. Це зумовлює необхідність реформування національного законодавства, що стосується потерпілого та його представника, з метою приведення його у відповідність зі світовими стандартами в галузі прав людини і громадянина. Слід відмітити, що діяльність адвоката-представника потерпілого у кримінальному процесі визначена тільки в найзагальніших рисах, без конкретизації прав та обов'язків. Далеко не всі проблемні питання у цьому напрямі належним чином вивчені, а деякі базуються на застарілому законодавстві й узагальненні слідчої та судової практики минулих років; не проаналізовані особливості зарубіжного досвіду участі адвоката-представника потерпілого на різних стадіях кримінального процесу.

Так, у ст. 1 Закону України «Про адвокатуру та адвокатську діяльність» зазначено, що адвокатом є фізична особа, яка здійснює адвокатську діяльність на підставах і в порядку, що передбачені законом. Адвокатська діяльність - це незалежна професійна діяльність адвоката щодо здійснення захисту, представництва та надання інших видів правової допомоги клієнту. Термін «представництво» визначено як вид адвокатської діяльності, що полягає в забезпеченні реалізації прав і обов’язків клієнта в цивільному, господарському, адміністративному та конституційному судочинстві, в інших державних органах, перед фізичними та юридичними особами, прав і обов'язків потерпілого під час розгляду справ про адміністративні правопорушення, а також прав і обов'язків потерпілого, цивільного позивача, цивільного відповідача у кримінальному провадженні [1]. Представництво адвокатом інтересів потерпілого у кримінальному судочинстві є основним засобом захисту його прав та законних інтересів. 


\section{Кримінальне право, кримінальний процес та криміналістика}

Системи кримінального судочинства більшості країн Европи і Північної Америки стосовно ролі і обсягу процесуальних прав потерпілого можна поділити на дві основні групи.

До першої групи відносяться країни, що використовують англосаксонську модель кримінального судочинства (Великобританія, Ірландія, США, Канада), законодавство яких не знає такої кримінально-процесуальної фігури як потерпілий. Наслідком цього є практично повна відсутність норм, регулюючих положення потерпілого у кримінальному процесі. У той же час, у цих країнах приділяється значна увага створенню ефективної системи соціального захисту і допомоги жертвам злочинів, а в останні два десятиліття в наявності і тенденція до помітного підвищення правового статусу жертв злочинів, до визнання необгрунтованої орієнтації на пріоритетну увагу до прав обвинувачених за рахунок збитків інтересам жертв [2, c. $96 ; 3]$.

До другої групи відносяться держави континентальної системи кримінального судочинства, де законодавство традиційно дає потерпілому право брати участь у кримінальному переслідуванні винного.

Розгляд правового статусу жертви злочину почнемо з Великобританії, оскільки їі кримінально-процесуальне право є найстарішою процесуальною системою світу. Дійсно, потерпілі в цій країні не мають жодного особливого статусу в системі кримінального правосуддя. До недавнього часу їх навіть не інформували про порушення кримінального переслідування. Жертва злочину розглядається як звичайний громадянин, зобов'язаний свідчити, сприяти поліції. Свідчення потерпілого потрібні лише в тих випадках, коли за наявності спірних моментів вони можуть сприяти судовому розгляду. У цьому випадку потерпілий зобов'язаний як свідок звинувачення відповідати на питання звинувачення і захисту. Тому систему правосуддя у Великобританії часто називають несприятливою для потерпілого.

У Англії і Уельсі представниками професії є баррістери («barristers» або радники «counsels») - це адвокати, які мають право виступати у вищих судових інстанціях. До їх повноважень належать такі: складання процесуальних документів (деталізованих позовних вимог або відкликання позову); консультування 3 питань права; представлення інтересів у суді. Адвокати не уповноважені: отримувати інструкції від клієнтів; займатись процесом розкриття інформації; спілкуватись зі свідками; проводити розслідування та керувати ними; займатись досудовим/позасудовим вирішенням спорів.

Соліситори («solicitors») - юристи, до чиїх функцій належать: отримувати інструкції/ доручення від клієнта; визначати відповідні норми англійського права; за необхідності, визначати адвоката, який спеціалізується у певній галузі права; давати інструкції адвокату; готувати та передавати позов до суду; вивчати можливості захисту щодо позову, поданого проти клієнта; отримувати інструкції від клієнта щодо захисту, відкликання позову; давати консультації щодо подальших дій і заяв, які можуть бути подані до винесення рішення судом; займатись процесом розкриття інформації та ознайомлення 3 нею; отримувати інструкції/доручення для підготовки письмових заяв свідків, для проведення інтерв'ю зі свідками; визначати експертів і давати інструкції експертам; готувати справу до слухання у суді; вести переговори про досудове/позасудове врегулювання спору [3, с. 28].

Ці юристи також за бажанням можуть отримати більш широкі повноваження [4, c. 10-11]. Зазначені суб'єкти мають право брати участь у кримінальному провадженні як захисники, проте для солісіторів обмеженим є право на публічні виступи в судах.

Стан справ у цій сфері фактично почав змінюватися лише з 22 лютого 1990 року, коли уряд опублікував «Хартію жертв злочинів» (Викладення прав жертв злочинів). У цьому документі, що є типовою програмоюпам'яткою для потерпілих, детально перераховані обов'язки всіх відомств, пов'язаних iз провадженням правосуддя, по відношенню до жертв злочинів. Проте положення Хартії стосуються питань забезпечення безпеки, інформаційного забезпечення і соціальної допомоги особам, постраждалим від злочинних посягань. Будь-яких помітних 
змін їх процесуального статусу доки не відбулось.

Значно далі в цьому напрямі просунулися СIIA, де, також як і у Великобританії, до початку 70-х років XX століття роль потерпілого зводилася до надання свідчень, необхідних для засудження винного. Потерпілі фактично були позбавлені будь-яких прав у процесі i, у свою чергу, стали розглядати кримінальний процес не лише як такий, що не відповідає їх вимогам, але взагалі байдужий до них.

Суспільний рух на підтримку прав жертв злочинів, що різко активізувався в кінці 1950-х років, зростання злочинності в країні, перш за все насильницької, розвиток віктимологічних досліджень і усвідомлення недосконалості сучасної системи кримінального правосуддя ініціювали послідовну діяльність урядів США і штатів, направлену на істотне розширення прав потерпілих.У процесі цього в Сполучених Штатах були прийняті десятки законів, що розширюють кримінально-процесуальні права потерпілих від злочинів [5, с. 10].

У кримінальному процесі США право адвоката представляти інтереси підозрюваного, обвинуваченого закріплено для всіх стадій. Це передбачено у VI Поправці Конституції СІА, Федеральному кримінальному процесуальному законодавстві, законодавстві штатів, прецедентах Верховного суду США и Верховних судів штатів. Проте, чіткого переліку прав захисника законодавець не пропонує.

Як зазначають дослідники, проблем участі захисника в стадії досудового розслідування у кримінальному процесі США, законодавчі норми і судові прецеденти надали такі основні права захиснику підозрюваного, обвинуваченого: 1) виступити на захист інтересів клієнта з моменту його затримання або арешту; 2) бачитися і консультувати свого клієнта до проведення допиту, а також протягом усього поліцейського розслідування; 3) брати участь у процедурі проведення допиту підзахисного, його впізнанні і обшуку; 4) ознайомитися 3 матеріалами обвинувачення; 5) заявляти клопотання, пов’язані 3 наданням доказів, реалізацією прав підзахисного та ін. Характер досудового роз- слідування в кримінальному процесі США, притаманна йому змагальність впливає на можливості адвоката при здійсненні захисту інтересів свого клієнта.

Захистом підозрюваних, обвинувачених на стадії досудового розслідування в СІІА можуть займатися як адвокати - члени колегії адвокатів, так і адвокати, які отримали ліцензію на ведення індивідуальної адвокатської практики [6, с. 12-15; 7, с. 355].

Історичним американські юристи вважають 1982 рік, коли Конгрес США прийняв Білль про захист жертв і свідків злочинів [8]. Це перший закон на федеральному рівні, що закріпив права жертв на участь у судовому процесі, а також їх права на захист і допомогу. Згідно з цим законом, потерпілі від злочинів, передбачених федеральним законодавством, мають такі права: на справедливе звернення з повагою до гідності і приватного життя потерпілого; на необхідний захист від правопорушника; бути сповіщеним про судові процедури; бути присутнім при всіх прилюдних судових процедурах, за винятком тих випадків, коли суд визначить, що на показання потерпілого можуть вплинути свідчення у суді інших осіб; на консультацію із прокурором, що підтримує обвинувачення у справі; на здобуття реституції; на інформацію про обвинувачення, вирок, висновок і звільнення правопорушника.

У цілому законодавство СШІА розвивається у напрямі неухильного розширення прав жертв злочину і посилення гарантій їх реалізації. Що ж до інституту представництва у процесі інтересів жертв злочину, то таке право у СШІА (втім, як і у Великобританії) визнавалось історично. При цьому, законодавством не регламентується процесуальний статус представників потерпілих як такий, та в цьому і немає необхідності, оскільки як адвокат, так і аторней, представляючи у процесі інтереси жертви, займають однакове процесуальне положення обвинувача зі всіма його широкими можливостями.

Класичною формою континентального змішаного кримінального процесу є кримінальний процес Франції. У цей час там діє Кримінально-процесуальний кодекс 1958 року з подальшими змінами і доповненнями [9, с. 323]. 
у французькому кримінально-процесуальному законодавстві поняття «потерпілий» і «цивільний позивач» $е$ синонімами. А. I. Аубенський звертає увагу, що «пред'явлення цивільного позову передбачає обов'язкове порушення кримінального переслідування. Такого роду цивільний позов може не містити вимоги про стягнення будь-якого матеріального блага» [10, с. 125]. Отже, у Франції під терміном «цивільний позов (action civile)» розуміється кримінальний позов, порушений за ініціативою приватної особи, на відміну від прилюдного позову (action publique), що порушується ех officio прокуратурою.

Вивчення правових актів, що регулюють діяльність адвокатів у Франції, показало, що законодавець не тільки визначив вимоги до адвокатів, а й передбачив кримінальну відповідальність за їх недотримання. Так, відповідно до ст. 433-17 КК Франції кримінальна відповідальність настає, якщо інша, не передбачена міжнародними угодами, особа, яка не зареєстрована належним чином у реєстрі колегії адвокатів і при цьому здійснює діяльність, що належить до виключної компетенції адвоката. За цією статтею кваліфікуються також дії особи, яка незаконно використовує статус і не відповідає встановленим для його набуття вимогам, 3 метою ввести в оману необмежене коло осіб щодо свого права на статус та належність до професії. Примітно, що у кримінальному процесуальному кодексі Франції законодавець детально не визначає підстави участі адвоката у кримінальному процесі, порядок його залучення та ін. Ці положення певним чином відображені у спеціальному законодавстві (Закон № 71-1130 від 31 грудня 1971 року «Про реформу низки судових і юридичних професій», Декрет № 91-1197 від 27 листопада 1991 року «Про адвокатуру і адвокатську діяльність», Закон № 2005-790 від 12 липня 2005 року «Про правила професійної етики адвоката», Нормативне рішення № 2005-003 «Про затвердження регламенту адвокатури і адвокатської діяльності у Франції»).

Цікаво, що французька процесуальна теорія абсолютно не розрізняє захисника обвинуваченого і представника потерпілого як самостійні суб'єкти кримінального процесу [11].

У Франції не відомий інститут ознайомлення сторін зі всіма матеріалами справи після закінчення досудового розслідування першої інстанції, проте, це не обмежує права сторін, оскільки ознайомлення зі справою відбувається при провадженні деяких слідчих дій, а крім того, у сторін є можливість повністю ознайомитися зі справою під час попереднього слідства другої інстанції (ст. 197 КПК).

Повноваження цивільного позивача за французьким кримінально-процесуальним законодавством залежать від того, у якому складі суду розглядається кримінальна справа: у суді присяжних, виправному трибуналі або поліцейському трибуналі.

Велика увага регламентації процесуального положення потерпілого і його представника приділена у Кримінально-процесуальному кодексі ФРН, прийнятому 1 лютого 1877 року і що діє в редакції від 7 квітня 1987 року. Досить сказати, що П'ята книга КПК ФРН повністю присвячена участі у процесі потерпілого (всього КПК ФРН складається із семи книг). У кримінальному процесі ФРН законодавець не обмежує коло захисників професійними адвокатами. Як захисники можуть брати участь адвокати, а також викладачі юриспруденції у німецьких вищих навчальних закладах згідно 3 Рамковим законом про вищі навчальні заклади, що мають кваліфікацію для обіймання посади судді. Інші особи можуть бути захисниками лише за умови затвердження судом. Якщо у випадку обов'язкової участі захисника обрана особа, що не належить до осіб, які можуть бути призначені захисником, вона може бути допущена у якості захисника за вибором лише поряд із особою, яка може бути призначена захисником [12].

Участь потерпілого у кримінальному судочинстві передбачено у трьох формах: як обвинувач у справах приватного обвинувачення, співобвинувача у справах прилюдного обвинувачення і цивільного позивача. Так, відповідно до $\$ 374$ КПК ФРН потерпілий може порушити розслідування у порядку приватного обвинувачення без попереднього звернення у прокуратуру у справах 
про недоторканість житла, службових приміщень (§ 123 КК ФРН), про образу (§§ 185 187 К КК), якщо образа не стосується жодної 3 політичних організацій, про порушення таємниці листування (§ 202 КК), про тілесні ушкодження (§§ 223, 223a, 230 КК), про загрозу і іншим злочинам, спеціально визначеним в абз. $1 \S 374$ КПК ФРН.

У КПК ФРН також передбачені випадки обов'язкової участі захисника, а саме: якщо справа у першій інстанції розглядається земельним Верховним судом або земельним судом; обвинуваченому пред'являється обвинувачення в учиненні кримінального злочину (в інших випадках голова призначає захисника за клопотанням або за офіційною ініціативою, якщо участь захисника убачається доцільною у зв'язку із тяжкістю діяння або складністю фактичної або юридичної сторони справи або якщо очевидно, що обвинувачений не може захищати себе сам, а саме, оскільки для потерпілого призначений адвокат); провадження може призвести до заборони зайняття професійною діяльністю; у відношенні обвинуваченого виконується попереднє ув'язнення; обвинувачений знаходиться у закладі виконання покарання не менше трьох місяців на підставі попередньої або наступної постанови суду і не звільнений не менше, ніж за два тижні до початку судового розгляду; для підготовки експертного висновку про психічний стан обвинуваченого можливе поміщення обвинуваченого до психіатричної клініки; здійснюється провадження щодо неосудних і процесуально недієздатних осіб; попередній захисник звільнений від участі у провадженні судовим рішенням [11]. Це узгоджується із Федеральним Положенням про адвокатуру, у якому передбачено, що адвокат повинен здійснювати захист або діяти як помічник, якщо його призначено захисником або помічником відповідно до положень Кримінально-процесуального кодексу, Закону про адміністративні правопорушення, Закону про міжнародну правову допомогу у кримінальних справах або Закону про взаємодію із Міжнародним кримінальним судом (§ 49) [13].
Зауважимо, що відповідно до § 397 а КПК ФРН потерпілому, промовцеві як співобвинувачеві має бути надана допомога у запрошенні адвоката, якщо справа є складною з правового і фактичного погляду, а потерпілий не може достатньою мірою забезпечити свої інтереси або зробити це йому не під силу. Адвокат запрошується головою, причому потерпілому протягом певного терміну надається можливість вибрати адвоката. Голова призначає названого потерпілим, адвоката його представником, якщо для відмови в цьому немає серйозних підстав. Рішення суду про надання допомоги потерпілому оскарженню не підлягає. Потерпілий має право принести термінову скаргу на визначення, яким було відмовлено у відкритті судового розгляду (стадія віддання під суд) або яким було припинено провадження у справі. КПК ФРН дозволяе потерпілому оскаржити такі визначення незалежно від того, оскаржив їх прокурор чи ні (§ 401).У той же час співобвинувач не може оскаржити вирок із метою, щоб за вчинення діяння засудженому було призначено інше покарання (§ 400 КПК).

Як цивільний позивач потерпілий також може скористатися послугами адвоката (§ 404 КПК). Потерпілий отримує копію вироку або виписку з нього (§ 406), проте позбавлений права оскаржити вирок, яким йому відмовлено у відшкодуванні заподіяної шкоди (§ 406 а КПК).

Законодавство ФРН детально регламентує і процесуальний статус адвоката-представника потерпілого. Глава 4 П'ятої книги КПК ФРН, хоча і іменується «Інші повноваження потерпілого», практично повністю присвячена повноваженням адвоката-представника потерпілого.

Згідно з § 406 е адвокат від імені потерпілого має право знайомитися 3 матеріалами справи, які передані до суду або підлягали 6 передачі до суду в разі порушення публічного переслідування, а також оглянути речові докази. У передбачених законом випадках у цьому праві адвокатові може бути відмовлено, наприклад, якщо таке ознайомлення загрожує цілям досудового розслідування або пов'язано з істотним затягуванням процесу. За клопотанням адвоката матеріали справи 


\section{Кримінальне право, кримінальний процес та криміналістика}

можуть бути навіть видані йому на руки, за винятком речових доказів, для ознайомлення 3 ними в адвокатській конторі. Відмова у задоволенні такого клопотання може наступити лише за наявності серйозних на те заперечень. На досудових стадіях процесу питання про ознайомлення адвоката потерпілого $з$ матеріалами справи вирішує прокуратура, але їі відмова може бути оскаржена до суду. Адвокат може знімати копії з документів, що знаходяться у матеріалах справи.

Під час допиту потерпілого у суді або прокуратурі має бути забезпечена участь його адвоката ( $\$ 406$ f). Він може заперечувати проти питань, що ставляться потерпілому (абз. 2 § 238, § 242) і клопотати з відома потерпілого про проведення закритого слухання справи.

Закон передбачає однакові наслідки нез'явлення адвоката - захисника і адвоката-представника потерпілого (§§ 145, 406 d КПК ФРН).

Отже, кримінально-процесуальне законодавство ФРН детальніше, ніж законодавство Франції визначає правовий статус адвоката-представника потерпілого і на відміну від останнього наділяє його такими процесуальними правами, які відсутні в особи, що представляється.

Законодавство інших країн континентальної Европи також приділяє велику увагу процесуальному статусу потерпілого i його представника.

У ст. 47 КПК Естонії зазначено, що адвокат-захисник має такі права: одержувати документи від фізичних та юридичних осіб, необхідні для надання юридичної допомоги людині, яка захищається; подавати докази; представляти запити і скарги; брати участь у процесуальних діях і робити заяви про умови, хід та результати процесуальних дій; використовувати технічні засоби при виконанні обов'язку захисту, якщо це не ускладнює проведення процесуальних дій; брати участь у процесуальних діях, виконуваних у присутності підзахисного на досудовій та судовій стадії; після вступу в справу вивчати протокол допиту підзахисного і документи про затримання підзахисного, а після завершення попереднього розслідування справи вивчати всі матеріали, наявні в справі; мати побачення 3 підзахисним без присутності інших людей необмежену кількість разів і 3 необмеженою тривалістю, якщо інше не передбачено КПК. У ст. 45 КПК Естонії зазначено, що адвокат має право вступити в кримінальну справу з моменту, коли особа набуває статусу підозрюваного. Відповідно до п. 2 ч. 1 ст. 72 КПК Естонії адвокат має право відмовитися давати показання як свідок про обставини, які стали йому відомими у зв'язку з наданням юридичної допомоги [14].

Так, жертва злочину у кримінальному процесі Австрії може брати участь як приватний обвинувач, а у справах публічного обвинувачення як потерпілий (у звичному для нас розумінні це цивільний позивач) i субсидіарного обвинувача (у разі заявленого ним клопотанням про переслідування особи при відмові від цього прокуратури). У всіх цих випадках потерпілий визнається стороною обвинувачення i може мати адвоката-представника, процесуальні права якого визнаються рівними правам того, що представляється (\$ 50 КПК Австрії). Низкою останніх змін і доповнень до КПК Австрії 1975 року потерпілий отримав можливість брати участь у слідчих діях і оскаржити рішення компетентним органам [15, c. 229].

у законодавстві Нідерландів і Швеції передбачено право потерпілого на надання йому безкоштовної юридичної допомоги. Аналогічні положення містяться у проєкті закону про надання допомоги потерпілим, представлено Міністерством юстиції Швейцарії.

Підводячи підсумок порівняльному дослідженню кримінального процесуального законодавства сучасних зарубіжних держав, слід визнати, що спільними рисами законодавства України й деяких зарубіжних країн $\epsilon$ наявність норм, що передбачають: визначення особи, яка може бути захисником у кримінальному процесі; вимоги на підтвердження повноважень захисника; обов'язки i права захисника; порядок залучення захисника; випадки обов'язкової участі захисника; умови відмови, заміни, відсторонення захисника; можливість призначення захисника, порядок і умови такого призначення. 
Залежно від структури кримінального процесу (відсутність стадії досудового розслідування), повноваження адвоката суттєво різняться.

Системи кримінального судочинства більшості країн Європи і Північної Америки стосовно ролі і обсягу процесуальних прав потерпілого поділяються на дві основні групи - англосаксонська модель кримінального судочинства (Великобританія, Ірландія, СІІА, Канада) та континентальна системи кримінального судочинства (Франція, ФРН). Зміцнення процесуального статусу потерпілого і його представника $\epsilon$ новітньою загальносвітовою тенденцією. Розвинені держави бачать вирішення проблеми захисту прав жертв злочину не в останню чергу в консультуванні і наданні їм юридичної допомоги. При цьому у цих країнах по-різному підходять до визначення процесуального статусу адвоката-представника потерпілого. Найчастіше його процесуальні можливості визнаються ідентичними процесуальним правам того, що представляється (Франція, Австрія). Виключення складає кримінально-процесуальне законодавство ФРН, де адвокат-представник потерпілого має особливий статус, що включає ряд важливих повноважень, які відсутні у самого потерпілого.

\section{Література}

1. Про адвокатуру та адвокатську діяльність : Закон від 5 лип. 2012 р. № 5076VI. Верховна Рада Украйни. URL: https://zakon. rada.gov.ua/laws/show/5076-17\#Text

2. Квашис В. Е., Вавилова $\lambda$. В, Зарубежное законодательство и практика защиты жертв преступлений. Москва : Издво МВД РФ, 1996. 256 с.

3. Михайловская И. Б. О положении личности в англо-американском уголовном процессе. Москва : Госюриздат, 1991. 199 с.

4. Навыки адвоката: Сборник материалов проекта «Профессиональное развитие адвокатов в ведении уголовных дел по экономическим преступлениям» (российский и британский опыт) / авторысоставители: А. Б. Гутников, С. В. Краузе, Ю. Н. Хапалюк. Серия «Права человека. СПб, 2014. 124 c.
5. Парий А. В. Потерпевший от преступления на досудебных стадиях уголовного судопроизводства СШША (сравнительно-правовое исследование) : монография. Волгоград, 2007. 110 с.

6. Курдова А. В. Защитник обвиняемого в уголовном процессе СІША: Досудебная стадия: автореф. ... канд. юрид. наук: 12.00.09. Москва, 1998. 19 с.

7. Дубівка І. В. Правова регламентація участі захисника в кримінальному процесі за законодавством зарубіжних країн. Юридичний часопис Національної академї̈ внутрішніх справ. 2017. № 1 (13). С. 350-360.

8. Міжнародний білль про права людини. Виклад фактів / Харківська правозахисна група. Харків : Фоліо, 2004. 62 с.

9. Уголовно-процесуальный кодекс Франции 1958 года / пер. с франц., предисл. С. В. Боботоваи, В. И. Каминской. Москва, «Прогресс», 2005. 438 с.

10. Аубенский А. И. Реформа уголовного процесса во Франции (19571959 гг.): дисс. ... канд. юрид. наук : 12.00.09. Спб, 2002. 218 с.

11. Основні акти, які регулюють адвокатуру i адвокатську діяльність у Франції. URL: http://cnb.avocat.fr/

12. Кримінальний процесуальний кодекс Федеративної Республіки Німеччина - Strafprozessordnung (StPO). URL: http:// pub.ub.uni-potsdam.de/volltexte/2012/6177.

13. Федеральне положення про адвокатуру у редакції із виправленнями, опубліковане у Частині III Федерального вісника законів, реєстраційний номер 303-8 із змінами, внесеними статтею 7 Закону від 10 жовтня 2013 року (Федеральний вісник законів), ч. 1, стор. 3786. URL: unba.org.ua assets bundesrechtsanwaltsordnung-ukr.

14. Кримінально-процесуальний кодекс Естонії від 30 грудня 2004 року. URL: https://www.riigiteataja.ee/aNt/13311874?leiaKehtiv

15. Банчук О. А., Демкова М. С. Правова допомога: зарубіжний досвід та пропозиції для України. Київ: Факт, 2004. $504 \mathrm{c}$. 


\section{Кримінальне право, кримінальни ЗАРУБІЖНИЙ ДОСВІД РЕГААМЕНТАЦІЇ КРИМІНААЬНОЇ ПРОЦЕСУАЛЬНОЇ ДІЯАЬНОСТІ АДВОКАТА-ПРЕДСТАВНИКА ПОТЕРПІАОГО}

У статті розглянуто соціально-правовий статус адвоката за законодавством деяких зарубіжних країнах з визначенням особливостей його діяльності. Проаналізовано кримінальне процесуальне законодавство деяких зарубіжних країн. Систему кримінального судочинства більшості країн Європи і Північної Америки розподілено на країни, що використовують англосаксонську модель кримінального судочинства, законодавство яких не знає такого учасника кримінального процесу як потерпілий та континентального змішаного кримінального процесу, у якому кримінально-процесуальне законодавство Німеччини детальніше, ніж законодавство Франції, визначає правовий статус адвоката-представника потерпілого i, на відміну від останнього, наділяє його такими процесуальними правами, які відсутні в особи, яку представляють.

За результатами порівняння законодавства України та деяких зарубіжних країн щодо участі захисника в стадії досудового розслідування констатовано, що їх положення подібні. Це пояснюється поглибленням міжнародного співробітництва в боротьбі зі злочинністю, розвитком принципу верховенства права, захисту прав людини, підсиленням демократичних стандартів у кримінальному судочинстві, широким застосуванням правових позицій Европейського Суду 3 прав людини. Встановлено, що правова регламентація діяльності адвокатів у форматі Європейського Союзу грунтується на вимогах національного законодавства цих країн. Схожий підхід застосовано і в Україні.

3'ясовано, що спільними рисами законодавства України й деяких зарубіжних країн є наявність норм, що передбачають: визначення особи, яка може бути захисником у кримінальному процесі; вимоги на підтвердження повноважень захисника; обов'язки і права захисника; порядок залучення захисника; випадки обов'язкової участі захисника; умови відмови, заміни, відсторонення захисника; можливість призначення захис- ника, порядок і умови такого призначення. Залежно від структури кримінального процесу (відсутність стадії досудового розслідування), повноваження адвоката суттєво різняться.

Системи кримінального судочинства більшості країн Європи і Північної Америки стосовно ролі і обсягу процесуальних прав потерпілого поділяються на дві основні групи - англосаксонська модель кримінального судочинства (Великобританія, Ірландія, США, Канада) та континентальна системи кримінального судочинства (Франція, ФРН). Зміцнення процесуального статусу потерпілого і його представника $е$ новітньою загальносвітовою тенденцією. Розвинені держави бачать вирішення проблеми захисту прав жертв злочину не в останню чергу в консультуванні і наданні їм юридичної допомоги. При цьому у цих країнах по-різному підходять до визначення процесуального статусу адвоката-представника потерпілого. Найчастіше його процесуальні можливості визнаються ідентичними процесуальним правам того, що представляється (Франція, Австрія). Виключення складає кримінально-процесуальне законодавство ФРН, де адвокат-представник потерпілого має особливий статус, що включає ряд важливих повноважень, які відсутні у самого потерпілого

Ключові слова: адвокат, представник потерпілого, кримінально-процесуальна діяльність, розслідування, надання правової допомоги.

\section{FOREIGN EXPERIENCE IN REGULATING THE CRIMINAL PROCEEDINGS OF THE VICTIM'S LAWYER}

The article considers the social and legal status of a lawyer under the laws of some foreign countries with the definition of the peculiarities of his activity. The criminal procedural legislation of some foreign countries is analyzed. The criminal justice system of most European and North American countries is divided into countries that use the Anglo-Saxon model of criminal justice, whose legislation does not recognize such a participant in the criminal process as the 


\section{АНОТАЦІЯ}

у статті розглянуто сочіально-правовий статус адвоката за законодавством деяких зарубіжних країнах з визначенням особливостей його діяльності. Систему кримінального судочинства більшості краӥн Европи і Північної Америки розподілено на країни, що використовують англосаксонську модель кримінального судочинства, законодавство яких не знає такого учасника кримінального процесу як потерпілий та континентального змішаного кримінального процесу, у якому кримінальне процесуальне законодавство визначає правовий статус адвоката-представника потерпілого, а деяких 3 них наділяе його такими прочесуальними правами, які відсутні в особи, яку представляють.

За результатами порівняльного дослідження встановлено, що законодавство Украйни та зарубіжних країн щодо участі захисника в стадї̈ досудового розслідування подібні. Це пояснюється поглибленням міжнародного співробітництва в боротьбі зі злочинністю, розвитком принципу верховенства права, захисту прав людини, підсиленням демократичних стандартів у кримінальному судочинстві, иироким застосуванням правових позииій Європейсъкого Суду з прав людини. Встановлено, що правова регламентаиія діяльності адвокатів у борматі Европейсъкого Союзу грунтується на вимогах начіонального законодавства изих краӥн.

Ключові слова: адвокат, представник потерпілого, кримінально-прочесуальна діяльність, розслідування, надання правової допомоги.

victim and the continental mixed criminal process, in which German criminal procedure defines more detail than French the legal status of the lawyer-representative of the victim and, unlike the latter, endows him with such procedural rights that the person he represents does not have.

According to the results of the comparison of the legislation of Ukraine and some foreign countries regarding the participation of the defense counsel in the stage of pre-trial investigation, it was stated that their provisions are similar. This is due to the deepening of international cooperation in the fight against crime, the development of the rule of law, protection of human rights, strengthening democratic standards in criminal proceedings, the wide application of the legal position of the European Court of Human Rights. It is established that the legal regulation of lawyers in the format of the European Union is based on the requirements of the national legislation of these countries. A similar approach is used in Ukraine.

It was found that the common features of the legislation of Ukraine and some foreign countries are the existence of rules that provide for: the definition of a person who can be a defender in criminal proceedings; requirements for confirmation of the powers of the defender; duties and rights of the defender; the procedure for attracting a lawyer; cases of mandatory participation of defense counsel; conditions of refusal, replacement, removal of the defender; the possibility of appointing a defender, the procedure and conditions of such appointment. Depending on the structure of the criminal process (absence of a pre-trial investigation stage), the powers of a lawyer differ significantly.

The criminal justice systems of most European and North American countries regarding the role and scope of procedural rights of the victim are divided into two main groups - the Anglo-Saxon model of criminal justice (UK, Ireland, USA, Canada) and the continental criminal justice system (France, Germany). Strengthening the procedural status of the victim and his representative is the latest global trend. Developed countries see the solution to the problem of protecting the rights of victims of crime, not least in counseling and providing them with legal assistance. At the same time, these countries have different approaches to determining the procedural status of the victim's lawyer. Most often, its procedural possibilities are recognized as identical to the procedural rights of what is represented (France, Austria). The exception is the criminal procedure legislation of Germany, where the lawyerrepresentative of the victim has a special status, which includes a number of important powers that are not available to the victim

Keywords: lawyer, victim's representative, criminal procedure activity, investigation, legal aid. 


\title{
ШКОДА ОДНА ІЗ СКЛАДОВИХ ЕЛЕМЕНТІВ ТЕРМІНА «ПОТЕРПЈЛОГО» ЗА ПЕРЕШКОДЖЕННЯ З'ЯВЛЕННЮ СВІДКА, ПОТЕРПІЛОГО ЕКСПЕРТА, ПРИМУШУВАННЯ ЇХ ДО ВІДМОВИ ВІД ДАВАННЯ ПОКАЗАНЬ ЧИ ВИСНОВКУ
}

\author{
КОВАЛЕНКО Дмитро Анатолійович - здобувач кафедри кримінального \\ права Національної академії внутрішніх справ
}

УДК 343.3/.7

DOI 10.32782/LAW.2020.3.20

\section{Постановка проблеми}

На сьогодні першочергове завдання нашої держави - це підвищення ефективності правосуддя, від впровадження яких у судову систему, а також у діяльність інших органів буде залежати дотримання прав та свобод людини в Україні, їх законних інтересів, оскільки охорона порядку здійснення правосуддя є однією 3 основних завдань кримінального законодавства України, а забезпечуючи дотримання чинного законодавства в державі, тим самим підтримуючи належний правопорядок у суспільстві. Поняття майнової шкоди, завданої кримінальним правопорушенням потерпілому, охоплює: заподіяну кримінальним правопорушенням особі пряму, безпосередню шкоду в тї майновому та грошовому виразі; неодержані внаслідок скоєння кримінального правопорушення доходи; оцінені у грошовому виразі витрати на лікування, протезування, відновлення здоров'я потерпілого, а в разі його смерті - на поховання й виплати 3 підтримання матеріального добробуту і виховання непрацездатних членів сім'ї потерпілого та його неповнолітніх дітей, а також кошти, витрачені закладом охорони здоров'я на стаціонарне лікування потерпілої особи. Коли відсутня фізична і матеріальна шкода, то як наслідок кримінальних дій завжди є моральна шкода, яка виступає складовою частиною всякої шкоди, завданої особі кримінальним правопорушенням.
Аналіз останніх досліджень і публікацій

Проблемні питання щодо дослідження понятійного аспекту шкоди, як одного із складових елементів «потерпілий» кримінального правопорушення, передбаченого ст. 386 КК України, досліджували В.I. Тютюгін, В.I. Борисов, М.I. Хавронюк, М.І. Мельник, О.І. Габро, Н.Ю. Алексеєва, М.І. Панов та ін. Проте до цього часу ці питання не отримали свого належного вирішення.

\section{Мета статті}

Розкриття проблемних питань понятійного аспекту шкоди, і моральної, і матеріальної, як одної із складових елементів «потерпілий» кримінального правопорушення, передбаченого ст. 386 КК України при кваліфікації цього діяння.

\section{Виклад основного матеріалу}

Що стосується самого поняття «потерпілий», то в юридичній літературі спостерігається широкий спект думок. Особливо ускладнилася ситуація з визначенням поняття терміна «потерпілий» після того, як законодавець у новому КПК України значно збільшив коло осіб, які можуть бути потерпілими в кримінальному провадженні. Проте, розмежувальну функцію може виконувати не потерпілий у цілому, а специфічні його ознаки. Причому ці ознаки повинні бути спеціальними - вказувати на особливості потерпілого 
щодо певного складу кримінального правопорушення. Неможливо розмежовувати суміжні склади кримінального правопорушення, спираючись лише на ознаки потерпілого, якщо в одному складі кримінальних правопорушень у законі названі особливі характеристики потерпілого, а у іншому - ні, тобто в другому випадку потерпілий не є ознакою складу кримінального правопорушення. Тому ним може бути будь-яка особа, якій кримінальним правопорушенням заподіяно фізичну, моральну чи матеріальну шкоду. На думку I.B. Строкова, потерпілий, як учасник кримінального процесу, потребує найпильнішої уваги і турботи з боку держави, оскільки вона не забезпечила його захист від посягань. Крім того, наявні механізми не забезпечують поновлення його прав та майна [6, с. 280].

Заподіяння шкоди є ще одним складовим елементом у визначенні терміну «потерпілий». У статті 55 КПК України вказано на три види шкоди щодо фізичної особи - моральна, фізична або майнова шкоди, а щодо юридичної особи, то це тільки шкода майнова. До того ж, у контексті загальнопопереджувальної дії кримінального закону є підстави говорити про непряму охорону нормами кримінального права потенційних потерпілих, як встановлення факту задоволення інтересів громадськості у зв'язку із дотриманням вимог кримінального закону певними особами, і відповідно до наявності у кожної особи відчуття захищеності кримінально-правовими нормами.Тому поняття «потерпілий» безпосередньо пов'язане зі шкодою, яка може бути спричинена тільки внаслідок вчинення кримінального правопорушення (що визначається винятково на підставі кримінального закону). Відносно загального поняття «шкода» як серед учених так і практичних працівників будь-яких дискусій або розбіжностей немає. Однак стосовно визначення термінів «моральна шкода», «фізична шкода» i «майнова шкода» до теперішнього часу немає єдиного розуміння. Загальне поняття «шкода»сформулювали М.I. Гошовський і О.П. Кучинська, які вважають, що шкода - це об'єктивна категорія, що стапновить ті зміни, які настали в майновому, фізичному, психічному, моральному стані особи внаслідок вчинення кримінального правопорушення. Шкода, заподіяна кримінальним правопорушенням, і шкода, що є підставою для визнання особи потерпілою, має об'єктивний характер, i тому вона включається до об'єктивної сторони кримінального правопорушення. На їх думку, поняття майнової шкоди, завданої кримінальним правопорушенням потерпілому, охоплює: заподіяну кримінальним правопорушенням особі пряму, безпосередню шкоду в їі майновому та грошовому виразі; неодержані внаслідок скоєння кримінального правопорушення доходи; оцінені у грошовому виразі витрати на лікування, протезування, відновлення здоров'я потерпілого, а в разі його смерті - на поховання й виплати 3 підтримання матеріального добробуту i виховання непрацездатних членів сім’ї потерпілого та його неповнолітніх дітей, а також кошти, витрачені закладом охорони здоров'я на стаціонарне лікування потерпілої особи [4, с. 17]. Коли відсутня фізична і матеріальна шкода, то як наслідок кримінальних дій завжди є моральна шкода, яка виступає складовою частиною всякої шкоди, завданої особі кримінальним правопорушенням. М.С. Строгович під моральною шкодою розумів зганьблення честі людини, приниження їі гідності, заподіяння тяжких душевних переживань, страждань, внесення в особисте життя або суспільне становище людини ускладнень [5, с. 257]. А.М. Белякова зазначила, що моральна шкода виражається в переживаннях і стражданнях, а також в обмеженні можливостей особи брати участь в активному житті [2, с. 53]. В.Я. Панарін вважає, що моральна шкода - це моральні страждання особи, спричинені злочинним посяганням на їі честь, гідність, а також і на інші блага, охоронювані як законом, так і нормами моралі [7, с. 78-79]. C.E. Абламський вважає, що моральну шкоду слід розуміти як викликану в психіці оцінку потерпілим протиправного приниження честі та гідності як людини та не- 


\section{Кримінальне право, кримінальний процес та криміналістика}

гативного сприйняття дій (бездіяльності), способу вчинення кримінального правопорушення, а також його відношення до погрози чи настанню наслідків [1, с. 161]. Така термінологічна відмінність поняття «моральної шкоди» перешкоджає однаковому тлумаченню кримінально-правових норм та ускладнюе завдання правозастосовних органів.

Тут слід зазначити, що не тільки вчені не мають єдиної думки про поняття «моральна шкода», але й вітчизняне законодавство не має чіткого визначення терміна «моральна шкода». 3 аналізу юридичної літератури видно, що на офіційному рівні визначення поняття «моральна шкода» почалося ще 3 Закону України «Про зовнішньоекономічну діяльність» від 16 квітня 1991 року № 959-XII, де було вказано, що «моральна шкода - шкода, яку заподіяно особистим немайновим правам суб'єктів зовнішньоекономічної діяльності та яка призвела або може призвести до збитків, що мають матеріальне вираження». Більш конкретно, але явно не повно i не коректно було дано визначення поняття «моральна шкода» у Законі України «Про порядок відшкодування шкоди, завданої громадянинові незаконними діями органів дізнання, попереднього слідства, прокуратури і суду» від 1 грудня 1994 року № 266/94-ВР, у якому зазначалося, що моральною шкодою визнаються страждання, заподіяні громадянинові внаслідок фізичного чи психічного впливу, що призвело до погіршення або позбавлення можливостей реалізації ним своїх звичок і бажань, погіршення відносин 3 оточенням, інших негативних наслідків морального характеру. Однак, обидва вище викладені визначення поняття «моральна шкода» не містить розгорнутого визначення терміна «моральна шкода». Пізніше у Закон України «Про порядок відшкодування шкоди, завданої громадянинові незаконними діями органів дізнання, попереднього слідства, прокуратури і суду» від 1 грудня 1994 р. № 266/94-ВР в 2000, 2003, 20092014 та 2015 р.p. вносилися зміни і доповнення, які стосувалися тільки права і порядку відшкодування шкоди. Визна- чення поняття «моральна шкода» в цих Законах не було змінено. Верховний суд України також намагався дати визначення поняттю «моральна шкода». Також це питання було розглянуто у п. 3 Постанови № 4 «Про судову практику в справах про відшкодування моральної (немайнової) шкоди» від 31 березня 1995 р. Вказано, що під моральною шкодою розуміються втрати немайнового характеру внаслідок моральних чи фізичних страждань або інших негативних явищ, заподіяних фізичній чи юридичній особі незаконними діями або бездіяльністю інших осіб. Відповідно до чинного законодавства моральна шкода може полягати, зокрема: у приниженні честі, гідності, престижу або ділової репутації, моральних переживань у зв'язку з ушкодженням здоров'я, у порушенні права власності (у тому числі інтелектуальної), прав, наданих споживачам, інших цивільних прав, у зв'язку з незаконним перебуванням під слідством і судом, у порушенні нормальних життевих зв'язків через неможливість продовження активного громадського життя, порушенні стосунків з оточенням, при настанні інших наслідків. Під немайновою шкодою, заподіяною юридичній особі, слід розуміти втрати немайнового характеру, що настали у зв'язку з приниженням її ділової репутації, посяганням на фірмове найменування, товарний знак, виробничу марку, розголошенням комерційної таємниці, а також вчиненням дій, спрямованих на зниження престижу чи підрив довіри до їі діяльності. Характерно, що й інші питання правового статусу потерпілого в КПК України розглядалися Верховним Судом України, що, поза сумнівом, сприяло правильному застосуванню кримінального законодавства на практиці, а також успішному захисту прав потерпілого. Так, згідно 3 п. 3 Постанови Пленуму Верховного Суду України «Про практику застосування судами законодавства, яким передбачені права потерпілих від злочинів» № 13 від 2 липня 2004 р., не можуть бути визнані потерпілими особи, які постраждали від кримінального правопорушення, вчиненого ними ж; водночас, 
оскільки закон не пов'язує позбавлення особи статусу потерпілого 3 неправомірністю їі поведінки, суди мають визнавати особу потерпілим й у випадках, коли вчинення щодо неї кримінального правопорушення спровоковано їі діями. При цьому неправомірність поведінки потерпілого може бути врахована при кваліфікації дій підсудного або призначенні йому покарання. У п. 2 цієї Постанови вказано, що у справі про незакінчений злочин особа визнається потерпілим за умови фактичного заподіяння їй моральної, фізичної або майнової шкоди. Потім Пленум Верховного Суду України Постановою N 5 від 25.05.2001 р. «Про внесення змін та доповнень до постанови Пленуму Верховного Суду України від 31 березня 1995 р. N 4 «Про судову практику в справах про відшкодування моральної (немайнової) шкоди» вніс такі зміни в цю Постанову: 1 . Пункт 3 був доповнений абзацом третім у такій редакції: «Під немайновою шкодою, заподіяною юридичній особі, слід розуміти втрати немайнового характеру, що настали у зв’язку 3 приниженням іï ділової репутації, посяганням на фірмове найменування, товарний знак, виробничу марку, розголошенням комерційної таємниці, а також вчиненням дій, спрямованих на зниження престижу чи підрив довіри до ії діяльності». 2. Абзац другий п. 5 був замінений двома абзацами, такого змісту: «Відповідно до загальних підстав цивільно-правової відповідальності обов'язковому з'ясуванню при вирішенні спору про відшкодування моральної (немайнової) шкоди підлягають: наявність такої шкоди, протиправність діяння їі заподіювача, наявність причинного зв’язку між шкодою і протиправним діянням заподіювача та вини останнього в їі заподіянні. Суд, зокрема, повинен з' ясувати, чим підтверджується факт заподіяння позивачеві моральних чи фізичних страждань або втрат немайнового характеру, за яких обставин чи якими діями (бездіяльністю) вони заподіяні, у якій грошовій сумі чи в якій матеріальній формі позивач оцінює заподіяну йому шкоду та з чого він при цьому виходить, а також інші обставини, що мають значення для вирішення спору. Особа (фізична чи юридична) звільняється від відповідальності по відшкодуванню моральної шкоди, якщо доведе, що остання заподіяна не з її вини. Відповідальність заподіювача шкоди без вини може мати місце лише у випадках, спеціально передбачених законодавством». 3. Пункт 9 викласти в такій редакції: «Розмір відшкодування моральної (немайнової) шкоди суд визначає залежно від характеру та обсягу страждань (фізичних, душевних, психічних тощо), яких зазнав позивач, характеру немайнових втрат (їх тривалості, можливості відновлення тощо) та з урахуванням інших обставин. Зокрема, враховуються стан здоров' я потерпілого, тяжкість вимушених змін у його життєвих і виробничих стосунках, ступінь зниження престижу, ділової репутації, час та зусилля, необхідні для відновлення попереднього стану, добровільне - за власною ініціативою чи за зверненням потерпілого - спростування інформації редакцією засобу масової інформації. При цьому суд має виходити із засад розумності, виваженості та справедливості. У випадках, коли межі відшкодування моральної шкоди визначаються у кратному співвідношенні 3 мінімальним розміром заробітної плати чи неоподатковуваним мінімумом доходів громадян, суд при вирішенні цього питання має виходити 3 такого розміру мінімальної заробітної плати чи неоподатковуваного мінімуму доходів громадян, що діють на час розгляду справи. Визначаючи розмір відшкодування моральної (немайнової) шкоди, суд повинен наводити в рішенні відповідні мотиви».

Дійсно, ці зміни і доповнення також мали значення для поліпшення трактування поняття «моральна шкода». Aле найбільш повно й правильно, на нашу думку, визначення терміна «моральна шкода» було викладено у прийнятому 2003 р. Цівільном кодексі України і найбільш вдало сформульоване визначення, у ч. 2 ст. 23 якого зазначено, що «моральна шкода» полягає: 1) у фізичному болю та стражданнях, яких фізична особа зазнала у зв'язку 3 каліцтвом або іншим 


\section{Кримінальне право, кримінальний процес та криміналістика}

ушкодженням здоров'я; 2) у душевних стражданнях, яких фізична особа зазнала у зв'язку з протиправною поведінкою щодо неї самої, членів її сім'ї чи близьких родичів; 3) у душевних стражданнях, яких фізична особа зазнала у зв'язку із знищенням чи пошкодженням їі майна; 4) у приниженні честі та гідності фізичної особи, а також ділової репутації фізичної або юридичної особи».

Міністерство юстиції України також робило спробу сформулювати поняття «моральна шкода». Так, 2004 р. у своєму листі-рекомендації від 13 травня 2004 р. № 35-13/797 було вказано, що «під моральною шкодою слід розуміти втрати немайнового характеру внаслідок моральних чи фізичних страждань, або інших негативних явищ, заподіяних фізичній чи юридичній особі незаконними діями або бездіяльністю інших осіб». Аналізуючи це визначення поняття «моральна шкода», не важко зробити висновок, що воно не тільки не вдосконалило його, а й ще більше зробило туманним і важким для застосування на практиці. Слушною є думка Н.В. Вербицької, яка вважає, що моральна шкода може полягати, зокрема: у приниженні честі, гідності, престижу або ділової репутації, моральних переживаннях у зв'язку з ушкодженням здоров'я; у порушенні права власності (в тому числі інтелектуальної), прав, наданих споживачам, інших цивільних прав, у зв'язку з незаконним перебуванням під слідством i судом; у порушенні нормальних життєвих зв'язків через неможливість продовження активного громадського життя, порушенні стосунків з оточенням, при настанні інших негативних наслідків [3, с. 89].

Майнова шкода, завдана кримінальним правопорушенням потерпілому, охоплює: заподіяну злочином особі пряму, безпосередню шкоду в їі майновому та грошовому виразі; неодержані внаслідок скоєння кримінального правопорушення доходи; оцінені у грошовому виразі витрати на лікування, протезування, відновлення здоров’я потерпілого, а в разі його смерті - на поховання й виплати 3 підтримання матеріального добробуту і виховання не- працездатних членів сім'ї потерпілого та його неповнолітніх дітей, а також кошти, витрачені закладом охорони здоров'я на стаціонарне лікування потерпілої особи. Слід зазначити, що згідно ст. 139 “Майно у сфері господарювання" Цивільного кодексу України майном визнається сукупність речей та інших цінностей (включаючи нематеріальні активи), які мають вартісне визначення, виробляються чи використовуються у діяльності суб'єктів господарювання та відображаються в їх балансі або враховуються в інших передбачених законом формах обліку майна цих суб'єктів.

\section{Висновки і пропозиції}

Аналіз поняття «потерпілий» та визначення терміну «моральна шкода» дає змогу зробити висновок, що конструктивним поняття «потерпілий» буде наступного змісту - це фізична або юридична особа, якій кримінальним правопорушенням заподіяно моральну, фізичну або майнову шкоду і допущена слідчим, прокурором або судом до кримінального провадження як його учасника. Таким чином, поняття майнової шкоди, завданої кримінальним правопорушенням потерпілому, охоплює: заподіяну кримінальним правопорушенням особі пряму, безпосередню шкоду в їі майновому та грошовому виразі; неодержані внаслідок скоєння кримінального правопорушення доходи; оцінені у грошовому виразі витрати на лікування, протезування, відновлення здоров'я потерпілого, а в разі його смерті - на поховання й виплати 3 підтримання матеріального добробуту i виховання непрацездатних членів сім'ї потерпілого та його неповнолітніх дітей, а також кошти, витрачені закладом охорони здоров'я на стаціонарне лікування потерпілої особи. Коли відсутня фізична і матеріальна шкода, то як наслідок завжди є моральна шкода, яка виступає складовою частиною всякої шкоди, завданої особі кримінальним правопорушенням. Підводячи підсумок вище викладеному, зосередимо увагу на понятті моральна шкода, що полягає: 1) у приниженні честі, гідності, престижу фізичної 


\section{АНОТАЦІЯ}

Охорона порядку здійснення правосуддя $\epsilon$ однією з основних завдань кримінального законодавства Украӥни, а забезпечуючи дотримання чинного законодавства в державі, тим самим підтримує належний правопорядок у суспільстві. На съогодні першочергове завдання нашої держави - це підвищення ефективності правосуддя, від впровадження яких у судову систему, а також у діяльність інших органів буде залежати дотримання прав та свобод людини в Україні, їх законних інтересів. Одним із завдань правосуддя є розгляд проблемних питань щодо дослідження понятійного аспекту шкоди, як одної із складових елементів «потерпілий» кримінального правопорушення перешкоджання з'явленню свідка, потерпілого, експерта, спеціаліста, примушування їх до відмови від давання показань чи висновку. Поняття майнової шкоди, завданої кримінальним правопорушенням потерпілому, охоплює: заподіяну кримінальним правопорушенням особі пряму, безпосередню шкоду в ї майновому та грошовому виразі; неодержані внаслідок скоєння кримінального правопорушення доходи; оцінені у грошовому виразі витрати на лікування, протезування, відновлення здоров'я потерпілого, а в разі його смерті - на поховання й виплати з підтримання матеріального добробуту $i$ виховання непрацездатних иленів сім' потерпілого та його неповнолітніх дітей, а також кошти, витрачені закладом охорони здоров'я на стаціонарне лікування потерпілой особи. Коли відсутня фізична $і$ матеріальна шкода, то як наслідок кримінальних дій завжди є моральна шкода, яка виступає складовою частиною всякої шкоди, завданої особі кримінальним правопорушенням. Поняття «моральна шкода», шзо полягає: 1) у приниженні честі, гідності, престижу фбізичной особи, а також ділової репутаиї бізичної або юридичної особи; 2) у моральних переживаннях у зв'язку з ушкодженням здоров'я; 3) у зв'язку з незаконним перебуванням під слідством і судом; 4) у порушенні права власності (у тому числі інтелектуальної); 5) у порушенні прав, наданих споживачам, інших ичвільних прав; 6) у душевних стражданнях, яких фізична особа зазнала у зв'язку із знищенням чи пошкодженням ї̈ майна; 7) у порушенні нормальних життевих зв'язків через неможливість продовження активного громадського життя.

Ключові слова: потерпілий, шкода моральна, шкода матеріальна, шкода фбізична, кримінальне правопорушення передбачене ст. 386 КК України.

особи, а також ділової репутації фізичної або юридичної особи; 2) у моральних переживаннях у зв'язку 3 ушкодженням здоров'я; 3) у зв'язку з незаконним перебуванням під слідством і судом; 4) у порушенні права власності (у тому числі інтелектуальної); 5) у порушенні прав, наданих споживачам, інших цивільних прав; 6) у душевних стражданнях, яких фізична особа зазнала у зв'язку із знищенням чи пошкодженням їі майна; 7) у порушенні нормальних життєвих зв'язків через неможливість продовження активного громадського життя.

\section{Література}

1. Абламський С.Е. Захист прав і законних інтересів потерпілого у кримінальному провадженні : монографія. Х. : Панов, 2015. 240 с.

2. Белякова А. М. Возмещение причиненного вреда. Москва: изд-во МГУ, 1972. $101 \mathrm{c.}$

3. Вербицька Н.В. Кримінально-правова характеристика погрози або насильства щодо захисника чи представника особи: дис. ... канд. юрид. наук: 12.00.08. К., 2016. 262 c.

4. Гошовський М. І., Кучинська О.П. Потерпілий у кримінальному процесі України. К.: Юрінком Інтер, 1998. 192 с.

5. Строгович M. С. Курс советского уголовного процесса. T. 1. Основные положения науки советского уголовного процесса. Москва : Наука, 1968. 470 с.

6. Строков I. В. Організаційні та правові заходи забезпечення прав потерпілого від злочину. Бюлетень Міністерства юстииї̈ Украӥни. 2008. № 1. С. 280-283.

7. Панарин В.Я. Защита имущественных прав личности в уголовном процессе России. Москва: Юр-Книга, 2007. 348 с. 


\section{Кримінальне право, кримінальний процес та криміналістика}

DAMAGE ONE OF THE COMPONENTS OF THE TERM «VICTIM» FOR OBSTACLING THE APPEARANCE OF A WITNESS, A VICTIM EXPERT, FORCING THEM TO BE INVOLVED IN

Today, the main core is the priority task of our state - to increase the efficiency of justice, respect for human rights and freedoms in Ukraine, their legitimate interests. The need to focus on problematic issues of the conceptual aspect of harm, as one of the components of the «victim» of a criminal offense under Art. 386 of the Criminal Code of Ukraine in qualifying this act. Disclosure of the conceptual apparatus of property damage caused by a criminal offense to the victim includes: direct, direct damage caused to the person by the criminal offense in its property and monetary terms; income not received as a result of committing a criminal offense; estimated in monetary terms the costs of treatment, prosthetics, recovery of the victim, and in case of his death - for burial and payments for the maintenance of material well-being and upbringing of disabled family members of the victim and his minor children, as well as funds spent by the institution health for inpatient treatment of the victim. When there is no physical and material damage, then as a consequence of criminal actions there is always moral damage, which is an integral part of any damage caused to a person by a criminal offense.

Thus, the concept of property damage caused by a criminal offense to the victim includes: caused by a criminal offense to a person direct, immediate damage in its property and monetary terms; income not received as a result of committing a criminal offense; estimated in monetary terms the costs of treatment, prosthetics, recovery of the victim, and in case of his death - for burial and payments for the maintenance of material well-being and upbringing of disabled family members of the victim and his minor children, as well as funds spent by the institution health for inpatient treatment of the victim. When there is no physical or material damage, the consequence is always moral damage, which is an integral part of any damage caused to a person by a criminal offense. Summing up the above, we focus on the concept of moral harm, which consists of: 1) humiliation of honor, dignity, prestige of an individual, as well as the business reputation of an individual or legal entity; 2) in moral distress due to damage to health; 3) in connection with illegal stay under investigation and trial; 4) in violation of property rights (including intellectual property); 5) in violation of the rights granted to consumers and other civil rights; 6) in mental suffering suffered by an individual in connection with the destruction or damage of his property; 7) in violation of normal life ties due to the impossibility of continuing active public life.

Key words: victim, moral damage, material damage, physical damage, criminal offense provided by Art. 386 of the Criminal Code of Ukraine. 


\title{
МЕЖДУНАРОДНО-ПРАВОВОЕ РЕГУЛИРОВАНИЕ БОРЬБЫ С ЛЕГАЛИЗАЦИЕЙ ДЕНЕЖНЫХ СРЕДСТВ ИЛИ ИНОГО ИМУЩЕСТВА, ПРИОБРЕТЁННЫХ ПРЕСТУПНЫМ ПУТЁМ
}

\author{
НУРИЕВ Эльнур - докторант Бакинского государственного университета \\ (Баку, Азербайджан) \\ УДК : 343.3 \\ DOI 10.32782/LAW.2020.3.21
}

\begin{abstract}
В этой статье рассматриваются международно-правовъе документь, подготовленнъие международнъими организачиями, включая ООН, Группу разработки финансовъхх мер борьбъ с отмыванием денег (ФАТФ), Эгмонтской группь, Базельский комитет и другие. Бълли описанъ основнъие характеристики этих документов, итобы понять важность их в области борьбы с отмьлванием денег. Статья служит руководством исторического развития международного законодательства по борьбе с отмывванием денег.

Ключевъе слова: грязнъле деньги, легализачия, международно-правовое регулирование, $Ф А Т \Phi$
\end{abstract}

Большинство международных документов, касающихся борьбы с легализацией денежных средств или иного имущества, приобретённых преступным путём, определено как мягкое право (softlaw). В отличие от жёсткого права (hardlaw), нормы этих актов не имеют обязательного характера.У них рекомендательный характер, и они не являются нормами международного права. Стороны должны принять соответственные внутренние акты для того, чтобы мягкое право создавало обязательства для них.

Первым международным шагом в борьбе отмывания денег считается Венская Конвенция 1990 года. Так как другие акты о борьбе с отмыванием денег вступили в силу после Венской Конвенции и фундаментальные основы и принципы о борьбе с отмыванием денег впервые были изложены тут, эта конвенция является источником вдохновения для развития других международных актов в этой сфере. Надо отметить: тот факт, что термин «отмывание денег» не был использован в Конвенции. Стороны Конвенции должны криминализировать преобразование или передачу, сокрытие или маскировку имущества, приобретённого преступным путём. Так как ответственность только по преступлениям о наркотиках была урегулирована в Конвенции, её нельзя считать полноценной для международной борьбы с отмыванием денег. В Конвенции также предусмотрена взаимная правовая помощь сторон в расследовании, преследовании и судебном разбирательстве преступлений, усмотренных в соответствующем пункте, а также её цели, формы запроса и основы для отказа. 190 государств являются сторонами Конвенции.

Другой конвенцией Организации Объединённых Наций в этой области является Палермская конвенция против транснациональной организованной преступности от 2003 года. В Конвенции отмывание денег установлено одним из ключевых особенностей организованной преступности. Также дано различение первичной преступной деятельности и вторичной преступной деятельности (например, отмывание денег). Минимальные требования основных правонарушений по отмыванию денег для участников Конвенции - это участие в преступной организации (ст. 5), коррупция (ст. 8) и препятствие правосудию (ст. 23). Регулятив- 


\section{Кримінальне право, кримінальний процес та криміналістика}

ный и надзорный режим финансового сектора с целью выявления подозрительных операций - идентификация клиента, учёт и отчётность, международное сотрудничество, главные методы борьбы с отмыванием денег в рамках Палермской конвенции.

В рамках Программы Организации Объединённых Наций по международному контролю над наркотиками был принят Типовой законодательный акт об отмывании денег. Одной из целей данного Акта было унифицирование законодательств государств в борьбе с легализацией нелегальных доходов. Данный Акт носит рекомендательный характер и предоставляет модель для развития национальных законодательств в этой области.

Другой международный орган в сфере противодействия отмыванию денег - Базельский комитет по банковскому надзору (Базельский комитет) - был образован в 1974 году управляющими центральных банков. Комитет не имеет официального международного надзорного органа или силы закона. Он формулирует широкие надзорные стандарты и руководящие принципы, а также рекомендации изложения лучших практик по широкому кругу вопросов банковского надзора. Из надзора Базельского комитета три стандарта и руководящих принципа касаются вопросов отмывания денег.

Для борьбы с различными видами преступлений, в том числе и финансовыми, 12 декабря 1988 года главы центральных банков стран «Большой семёрки» подписали Базельское соглашение «О принципах регулирования работы банков, осуществления практического контроля за их деятельностью и предупреждения криминального использования банковских систем для «отмывания денег». Әти соглашения являются практически первым международном нормативном актом «мягкого права», регулирующим в основном нормативную/превентивную стороны отмывания денег. Идентификация личности клиентов является обязательным для финансовых организаций, и если это невозможно, деловые отношения должны быть разорваны.

В 1997 году Базельский Комитет издал свои Основные принципы эффективного банковского надзора (Core Principles), которые представляют собой всеобъемлющий проект эффективной системы банковского надзора и охватывают широкий круг тем. Из 25 основных принципов один из них, основной принцип - 15, касается отмывания денег.

В дополнение к Основным принципам, Базельский Комитет издал "Принципы методологии”, которые содержат 11 конкретных критериев и пять дополнительных критериев, которые помогут оценить адекватность политики и процедур - знай своего клиента (KYC).

При полной поддержке Рекомендации Целевой группы по финансовым мероприятиям Комитет выпустил документ, озаглавленный «Разумное управление рисками, связанными с отмыванием денег и финансированием терроризма» в январе 2014 года, который обеспечивает основу наилучшей практики регулирования на широкой основе по рекомендациям ФАТФ. В документе рекомендации делятся по трём направлениям защиты от отмывания денег. В документе говорится, что персонал фронт-офиса, выступающий в роли клиента, должен быть рассмотрен как первая линия защиты от финансовых преступлений. Команда высшего руководства и комплайенс формирует вторую линию защиты от отмывания денег. Функция внутреннего аудита обеспечивает третью линию защиты и играет важную роль в независимой оценке управления рисками и контроля.

Другая международная организация в этой области Вольфсбергская группа - объединение одиннадцати глобальных банков, целью которого является развитие стандартов индустрии финансовых услуг и сопутствующих продуктов для КУС, политики по борьбе с отмыванием денег и финансированием терроризма. Стандарты Вольфсберга важны тем, что в них даётся краткий и чёткий обзор правил принятия клиентов и постоянного мониторинга. Кроме того, здесь раскрывается, что требуется от «должной осмотрительности» и в особенности, что определяет на практике источник богатства и источник средств. В тексте также указано, что может означать усиленное изучение ри- 
скованных и передовых методов работы с политически значимыми лицами (PEPs).

В 2002 году, следуя в основном новым правилам Закона США «О Патриотах» о банковском обслуживании корреспондентов, которые позднее были также учтены в новых Сорока рекомендациях ФАТФ, Вольфсберг разработал подробный свод правил для банковских операций корреспондентов. Принципы 2002 года определяют, что может повлечь за собой основанный на риске подход в банковском обслуживании корреспондентов, и по существу проводят различие между «стандартной» должной осмотрительностью для банков-корреспондентов и «повышенной» осмотрительностью для учреждений, занимающихся индикаторами более высокого риска. Вольфсберг недавно сделал ещё один шаг, призвав частные предприятия выступать в качестве центральных сертификационных агентств и создать международный реестр данных о должной осмотрительности, собираемых банками-корреспондентами. Этот шаг позволяет банкам работать намного экономичнее, чем в рамках традиционной системы, в которой каждый банк должен был применять свою собственную юридическую проверку к каждому потенциальному корреспонденту. Сами банки Вольфсберга просто действовали как «первопроходцы».

На национальном уровне подразделения финансовой разведки являются центральным звеном в борьбе с отмыванием денег. Для обмена информацией между подразделениями финансовой разведки разных стран было создано объединение подразделений разведки 69 стран под названием «Әгмонт» в 1995 году, в брюссельском дворце Әгмонт - Аренберг. В организацию включены рабочие группы по правовым и оперативным вопросам, привлечены и обучены новые сотрудники, а также решаются вопросы информационных технологий. При обмене информацией члены должны соблюдать принципы ограничения на разрешённое использование информации и конфиденциальность.

Одним из ключевых игроков в области противодействия отмывания грязных денег является Международная организация уголовной полиции (ИНТЕРПОЛ). По состо- янию на 2020 год, в состав Интерпола входит 194 государства. Главными функциями этой организации является ликвидация международной преступности, поддерживание обмена информацией между странами, стандартизация методов, применяемых правоохранительными органами при сборе и анализе информации.

Группа разработки финансовых мер борьбы с отмыванием денег (ФАТФ) - межправительственная организация, которая занимается выработкой мировых стандартов в сфере противодействия отмыванию преступных доходов и финансированию терроризма (ПОД/ФТ), а также осуществляет оценки соответствия национальных систем ПОД/ФТ этим стандартам. ФАТФ была создана не на основе международного договора. Поэтому она не является органом, который создаёт нормы обязательные для государств. Не случайно главным документом ФАТФ-а названы «Рекомендации». Первой задачей ФАТФ было установление международного стандарта по борьбе с отмыванием денег. ФАТФ выпустила свой первый набор международных стандартов по борьбе с отмыванием денег в 1990 году и сорок рекомендаций по отмыванию денег.

Методы и техники отмывания денег меняются в ответ на разработку контрмер, например использование юридических лиц для маскировки подлинного владения незаконным доходом и контроля над ним, и более широкое использование специалистов для предоставления консультаций и помощи в отмывании преступных средств. Эти факторы, в сочетании с опытом, полученным в результате процесса сотрудничества между странами и территориями ФАТФ, а также ряд национальных и международных инициатив привёл ФАТФ к рассмотрению и пересмотру Сорока рекомендаций в новую всеобъемлющую основу для борьбы с отмыванием денег и финансированием терроризма. На сегодня приоритетом является борьба с киберпреступлениями и финансовыми преступлениями, связанными с криптовалютами.

Но как работает политическое влияние ФАТФ, особенно в странах, не являющихся членами? ФАТФ проводит проверки уров- 


\section{Кримінальне право, кримінальний процес та криміналістика}

ня соответствия в рамках юрисдикций рекомендациям ФАТФ, и это обеспечивает определённый уровень стимула для их выполнения. Если ФАТФ считает, что страначлен (или страна, не являющаяся членом) не соответствует Рекомендациям, она может использовать ряд «поэтапных подходов», начиная с наименее агрессивных мер и усиливает давление, если страна продолжает не соблюдать их. Во-первых, соответствующая страна должна представлять отчёты о ходе работы в Секретариат ФАТФ и/или на его пленарных заседаниях. Если страна попрежнему отказывается сотрудничать, президент ФАТФ-а может направить письмо или делегацию высокого уровня правительству страны и/или включить страну в «серый список» или список юрисдикций, которые требуют дополнительного внимания со стороны органов взаимной оценки ФАТФ. При дальнейшем несоблюдении, ФАТФ может применить Рекомендацию 19 и опубликовать предупреждение для финансовых учреждений, что они должны «уделять особое внимание деловым отношениям и сделкам с лицами, компаниями и финансовыми учреждениями, расположенными в стране, не соответствующей требованиям». Наконец, ФАТФ может приостановить членство страны, не соответствующей требованиям. И если рассматриваемая юрисдикция является страной, не являющейся членом, ФАТФ может включать эту страну, которая не соблюдает требования, в «не сотрудничающие страны или территории» (NCCT или «blacklist»).

\section{Аитература}

1. Базельское соглашение «О принципах регулирования работы банков, осуществления практического контроля за их деятельностью и предупреждения криминального использования банковских систем для «отмывания денег», 12 декабря 1988.

2. Конвенция «О борьбе против незаконного оборота наркотических средств и психотропных веществ», Организация Объединённых Наций, 1 ноября 1990.

3. Конвенции «Против транснациональной организованной преступности», Организация Объединённых Наций, 29 сентября 2003.
4. “Методологии основных принципов”, Базельский комитет, 11 октября 1999.

5. Международные стандарты ФАТФ-а в сфере борьбы с отмыванием денег и финансированием терроризма и распространения оружия массового уничтожения, 2012.

6. «Надлежащая проверка клиентов для банков», Базельский комитет, 4 октября 2001.

7. «Основные принципы эффективного банковского надзора», Базельский комитет, 22 сентября 1997.

8. Принципы Вольфсберга «По борьбе с отмыванием денег для частного банковского дела», 2012.

9. Принципы Вольфсберга «По борьбе с отмыванием денег для банков-корреспондентов», 21 октября 2002.

10. Разумное управление рисками, связанными с отмыванием денег и финансированием терроризма, Базельский комитет,15 января 2014.

11. Страсбургская Конвенция «Об отмывании, выявлении, изъятии и конфискации доходов от преступной деятельности», Совет Европы, 8 ноября 1990.

12. Типовой закон «Об отмывании денег и финансировании терроризма», Организация Объединённых Наций, 1 декабря 2005.

13. www.egmontgroup.org

14. www.interpol.int

\section{Elnur Nuriyev \\ INTERNATIONAL LEGAL REGULATION OF COMBATING THE LEGALIZATION OF MONEY OR OTHER PROPERTY ACQUIRED BY CRIMINAL MEANS}

This article examines international legal documents prepared by international organizations, including the UN, the Financial Action Task Force on Money Laundering (FATF), the Egmont Group, the Basel Committee and others. The main characteristics of these documents were described in order to understand their importance in the field of combating money laundering. The article serves as a guide to the historical development of international anti-money laundering legislation.

Key words: dirty money, legalization, international legal regulation, FATF 


\title{
МІЖНАРОДНО-ПРАВОВІ ГАРАНТІЇ ПРАВА НА КОМПРОМІС У КРИМІНАЛЬНОМУ СУДОЧИНСТВІ
}

\author{
СІРОТКІНА Марія Вячеславівна - кандидат юридичних наук, здобувач \\ кафедри кримінального процесу та криміналістики Інституту права Київського \\ національного університету імені Тараса Шевченка
}

УДК 343.131 (477)

DOI 10.32782/LAW.2020.3.22

\begin{abstract}
Вступ
Незважаючи на суттєві переваги процедур відновного правосуддя, неформальний характер під час їх застосування містить у собі небезпеку порушення прав сторін конфлікту. У зв'язку з цим, як зазначає у своїх рішеннях Европейський суд з прав людини, будь-яка відмова від процесуальних прав повинна завжди бути зроблена у недвозначній формі і супроводжуватися мінімальними гарантіями, співмірними з їі важливістю. Крім того, вона не повинна суперечити жодному
\end{abstract} важливому суспільному інтересу [1].

У юридичній літературі питанням, пов'язаним з гарантуванням прав учасників кримінального процесу під час альтернативних судовому способів вирішення кримінально-правового конфлікту, присвятили праці Р.В. Новак, Г.Ю. Саєнко, А.С. Трекке, П.В. Холодило та ін.

У своїх дисертаційних дослідженнях автори неодноразово звертали увагу на необхідність гарантування прав підозрюваного (обвинуваченого), потерпілого, юридичної особи нормами чинного кримінального процесуального законодавства [2, с. 1; 3, с. 15].

Однак, ефективна реалізація права на компроміс відповідно до положень національного законодавства була 6 неможливою без впровадження міжнародних стандартів у правову систему України.

\section{Постановка завдання}

Враховуючи зазначене, метою статті є аналіз кримінально-процесуальних гаран- тій реалізації особою права на компроміс, закріплених у міжнародно-правових актах обов'язкового та рекомендаційного характеру.

\section{Результати дослідження}

Під гарантіями у кримінально-процесуальній науці розуміють систему правових засобів, встановлених законом для належного відправлення правосуддя, захисту прав і свобод людини в кримінальному процесі, здійснення завдань судочинства у кримінальних справах $[4$, с. $75 ; 5$, с. 229230].

На думку А.С. Стройкової кримінально-процесуальні гарантії - це встановлені кримінально-процесуальним законом правові засоби, якими охороняються і захищаються права і законні інтереси осіб, які беруть участь у кримінальному процесі, що включають як відповідні процесуальні приписи, так і діяльність відповідних державних органів, посадових та інших осіб за їх реалізації [6, с. 38]. Автор включив в поняття такі значимі ознаки, як «охорона і захист законних інтересів» і «діяльність державних органів і посадових осіб щодо реалізації їх охорони і захисту цих інтересів».

Найбільш повне, на нашу думку, визначення цього поняття наводить Ю.А. Іванов. Він розглядає кримінально-процесуальні гарантії як систему правових засобів забезпечення успішного вирішення завдань правосуддя і охорони законних інтересів 


\section{Кримінальне право, кримінальний процес та криміналістика}

усіх учасників провадження, що передбачає суворе дотримання встановлених законом форм і принципів судочинства, закріплення прав учасників процесу і умов їх реалізації, точне виконання обов'язків посадовими особами та органами, що здійснюють кримінально-процесуальну діяльність [7, с. 215].

3 огляду на це, кримінально-процесуальні гарантії - перш за все правові засоби. У розділі III Додатку до Резолюції 2002/12 Економічної і Соціальної Ради від 24 липня 2002 р. «Основні принципи застосування програм реституційного правосуддя в питаннях кримінального правосуддя» визначено, що держави повинні встановлювати керівні принципи i стандарти, які регулюють застосування програм реституційного правосуддя. Такі керівні принципи і стандарти повинні забезпечувати дотримання основних положень, що містяться в цьому документі, i стосуватися, зокрема, наступного:

а) умов для передачі справ програмами реституційного правосуддя;

b) розгляду справ після реституційного процесу;

с) кваліфікації, підготовки і оцінки посередників;

d) управління програмами реституційного правосуддя;

е) стандартів щодо компетенції та правил етики, що регулюють функціонування програм реституційного правосуддя [8].

Крім того, мають бути дотримані певні застереження; сторони повинні мати право на правову допомогу та, у разі необхідності, на тлумачення, роз'яснення. Підлітки повинні мати право на допомогу батьків [9].

Гарантії реалізації права на правову допомогу під час процедури примирення є однією зі складових частин гарантій доступу до юридичної допомоги. Як зазначає ПАРЕ у Резолюції № 2245 (2018) Асамблея, обов'язкова участь адвоката є однією 3 тих гарантій, які необхідні для того, щоб держави-члени користувалися потенційними перевагами, які можуть запропонувати системи відмови від судового розгляду, мінімізуючи загрози правам людини, зокрема праву на справедливий судовий розгляд [10].

У п. 8.1. зазначеної вище Резолюції Асамблея закликає всі держави-члени та держави, які мають статус спостерігача або інший статус у Раді Европи або Асамблеї, зробити обов'язковим залучення адвоката як умову дійсності угоди про визнання провини, у разі потреби за допомогою безоплатної юридичної допомоги для гарантування справедливого ставлення до відповідачів, зокрема вразливих, таких як молоді правопорушники, - як цього вимагає Стаття 6.3. с Конвенції [10].

Для порушника як сторони конфлікту держава повинна забезпечити ранній доступ до юридичної допомоги, а отже, до отримання консультації щодо позасудового вирішення кримінально-правового конфлікту. Відповідно до Керівництва Управління Організації Об'єднаних Націй з наркотиків і злочинності «Ранній доступ до юридичної допомоги в процесах кримінального правосуддя: керівництво для політиків і практиків» - означає доступ до юридичної допомоги 3 моменту підозри, арешту або затримання особи у зв'язку 3 кримінальним правопорушенням (залежно від того, яка подія настає раніше) і протягом всього періоду аж до першої появи перед суддею 3 метою визначення того, чи має обвинувачена особа бути затримано або звільнено в очікуванні суду.

Під юридичною допомогою при цьому «Принципи і керівні положення Організації Об’єднаних Націй, що стосуються доступу до юридичної допомоги в системах кримінального правосуддя» («UNPG») розуміють: юридичні консультації, допомогу i представлення осіб, затриманих, заарештованих або ув'язнених, підозрюваних або обвинувачених, або які притягуються до відповідальності у зв'язку з вчинення кримінальних правопорушень, а також жертв і свідків у процесі кримінального правосуддя, які надаються безкоштовно тим, хто не має достатніх засобів або коли того вимагають інтереси правосуддя [11].

Правова допомога покликана просувати концепції юридичної освіти, доступу до 
правової інформації та інших послуг, що надаються особам через альтернативні механізми вирішення спорів і процеси відновного правосуддя [11].

Відповідно до «Принципів і керівних положень Організації Об'єднаних Націй, що стосуються доступу до юридичної допомоги в системах кримінального правосуддя» («UNPG») держави повинні «гарантувати право на юридичну допомогу у своїх національних правових системах на найвищому рівні, включаючи, де це може бути застосовано, конституцію» (2013, Принцип 1).

Держави повинні розглядати надання правової допомоги своїм обов'язком. 3 цією метою вони мають розглянути, де це доречно, прийняття конкретного законодавства і нормативних актів і забезпечити наявність комплексної системи юридичної допомоги, яка була $б$ доступною, ефективною, стійкою і такою, що заслуговує довіри. Держави повинні виділяти необхідні людські та фінансові ресурси для системи юридичної допомоги [11].

Іншою гарантією реалізації права на компроміс у кримінальному судочинстві є інформування учасників про основні аспекти відновних процедур. Зміст положень Інструкції щодо кращого застосування чинної Рекомендації щодо медіації у кримінальних справах від 7 грудня 2007 р., прийнятої Европейською комісією 3 питань ефективного правосуддя, дозволяє виділити два рівні інформування: загальний та спеціальний кримінальнопроцесуальний.

Загальний рівень передбачає обов'язок держави вживати відповідні заходи для підвищення рівня обізнаності щодо переваг медіації серед широкої громадськості.

Такі заходи можуть передбачати: статті, інформаційні повідомлення в 3МІ, поширення інформації щодо медіації через буклети/брошури, Інтернет, плакати, телефонну лінію 3 питань медіації, інформаційні та консультаційні центри, цільові програми інформування, такі, як «тижні медіації», семінари та конференції, відкриті дні з медіації у судах та в організаціях, що надають послуги з медіації.
Держави, університети, інші наукові установи й зацікавлені особи повинні підтримувати та заохочувати проведення наукових досліджень у сфері медіації та відновного правосуддя.

Медіація та інші форми відновного правосуддя повинні бути включені в програми національної освіти у школах [12].

Спеціальний, кримінально-процесуальний рівень гарантування інформованості стосується конкретних сторін кримінально-правового конфлікту. Важливу роль у ньому відводить судам, прокуратурі та іншим органам кримінального правосуддя. Вони повинні бути здатними надати інформацію, організовувати інформаційні заходи з питань медіації та, де доречно, пропонувати потерпілим та/ чи правопорушникам взяти участь у медіації та/чи направити справу на медіацію. Країни-члени заохочуються налагоджувати та/чи вдосконалювати співпрацю між органами кримінального правосуддя та програмами медіації 3 метою здійснення більш ефективної роботи 3 потерпілими та правопорушниками [12].

Кодекс поведінки представників адвокатури також повинен містити зобов' язання або рекомендацію адвокатам вживати необхідних кроків для поширення відповідної інформації та, де доречно, пропонувати сторонам брати участь у медіації між потерпілим та правопорушником, а також захищати доцільність направлення справ на медіацію з боку компетентних органів [12].

У зв'язку з тим, що правоохоронні органи здійснюють втручання на ранніх етапах справи i, відтак, є першими, хто контактуе 3 потерпілими та правопорушниками, Інструкція щодо кращого застосування чинної Рекомендації щодо медіації у кримінальних справах звертає увагу на іхнє навчання, яке повинно передбачати досягнення розуміння відновного правосуддя.

Особлива увага повинна бути приділена питанню направлення справи на медіацію. Це може досягатись шляхом проведення навчання, яке включатиме інформацію про правопорушників та по- 


\section{Кримінальне право, кримінальний процес та криміналістика}

терпілих, а також шляхом поширення буклетів/брошур.

Як суд, так і прокуратура мають бути повністю поінформовані про процедуру медіації та бути свідомі щодо їі переваг та можливих ризиків. Це може досягатися через інформаційні заходи, а також базові й чинні навчальні програми.

Важливо заохочувати як інституційні, так і особисті контакти між медіаторами та суддями/прокурорами. Це може бути досягнуто, зокрема, шляхом проведення конференцій та семінарів.

Відновне правосуддя та медіація мають бути включені також до навчального плану як базових, так і чинних навчальних програм для адвокатів. Асоціації адвокатів повинні мати перелік організацій, що впроваджують програми медіації, та поширювати їх серед адвокатів.

Держава та асоціації адвокатів повинні вживати заходи для створення схем оплати праці адвокатів, які не відраджуватимуть їх від поради клієнтам щодо участі у медіації задля вирішення конфліктів [12].

3 огляду на закріплення у міжнародно-правових актах принципу добровільності альтернативних способів вирішення кримінально-правового конфлікту важливе значення має створення державою умов, які унеможливлюють примушування або схиляння сторін конфлікту 3 допомогою недобросовісних засобів до участі в процесах примирення або згоди 3 його результатами.

До таких умов необхідно віднести нормативне закріплення: 1) презумпції невинуватості у разі згоди порушника на застосування альтернативних способів вирішення кримінально-правового конфлікту; 2) недопустимості використання відомостей, повідомлених порушником під час процедури примирення, як доказів вини у подальшому судовому провадженні;3) доступності правосуддя та справедливого судового розгляду у випадку недосягнення компромісу.

Положення п. 9 Рекомендації № 6 R (87) 18 Комітету міністрів Ради Европи державам-членам «Стосовно спрощення кримінального правосуддя» 3 цього при- воду зазначає, що рішення органу, який здійснює переслідування обвинуваченого, про його умовне припинення не можна вважати еквівалентом засудження, доки обвинувачений не визнав своєї вини [13].

Відповідно до п. 7 принципів ООН реституційні процеси можуть застосовуватись лише за наявності достатніх доказів для пред'явлення обвинувачення правопорушника і вільно вираженої та добровільної згоди жертви і правопорушника [8].

Така ж умова передбачена п. 3 Рекомендації № 6 R (87) 18 Комітету міністрів Ради Европи державам-членам «Стосовно спрощення кримінального правосуддя» для застосування будь-яких інших альтернативних кримінальному переслідуванню способів вирішення кримінально-правового конфлікту, відповідно до якої рішення про відмову від переслідування може мати місце, якщо в органу, який здійснює таке переслідування, є адекватні докази вини [13].

Разом 3 тим слід погодитися 3 тим, що для застосування процедури примирення як альтернативної форми вирішення кримінально-правового конфлікту не завжди потрібне встановлення вини чи визнання iii обвинуваченим. Положення п.8 Принципів ООН визначає, що жертва і правопорушник повинні погоджуватися з основними обставинами справи як основи для їх участі у відновному процесі. Таким чином, конструкцію «визнання вини» замінює поняття «прийняття відповідальності за скоєне».

На практиці це означає, що суд, приймаючи кінцеве рішення у кримінальному провадженні, не зазначає у ньому, що обвинувачений «вину визнав» або «вину не визнав», а вказує на той факт, що він «згоден на примирення».

Із вимог п. 8 Принципів ООН про недопустимість використання у ході подальшого правового розгляду як доказів визнання порушником під час проведення компромісних процедур вини у вчинених діяннях, а також п. 14 принципів ООН про конфіденційний характер обговорень у рамках процедури примирення випли- 
ває обов'язок держави гарантувати право порушника відмовитися від дачі показань про обставини вчиненого кримінального правопорушення.

Крім того, кримінально-процесуальною гарантією реалізації права на компроміс повинно бути також закріплення положення про те, що факт недосягнення згоди під час процедури примирення не повинен використовуватися в рамках подальшого кримінального провадження. Відповідна вимога закріплена п. 16 Принципів ООН, а факт невиконання угоди чи іншого, ніж судове рішення, не повинен використовуватися як обгрунтування більш суворого вироку в ході подальшого кримінального провадження (п.17 Принципів ООН) [8].

Пунктом 16 Принципів ООН передбачено як гарантію реалізації права на компроміс у кримінальному судочинстві також доступ до правосуддя. Ця гарантія передбачає, що у тих випадках, коли домовленості між сторонами досягти не вдалось, справа повинна повернутись на розгляд у межах встановленого процесу кримінального правосуддя. Рішення щодо подальших дій повинно прийматись невідкладно.

Приймаючи рішення про участь у розв'язанні кримінально-правового конфлікту шляхом досягнення компромісу, особа повинна мати гарантії виконання умов досягнутих у такий спосіб домовленостей.

3 огляду на те, що за результатами досягнення компромісу сторони укладають угоду, їі предметом серед іншого $\epsilon$ конкретні зобов'язання, які повинна виконати та чи інша особа. Їх невиконання повинно тягнути за собою право іншої сторони звернутись до суду з вимогою зобов'язати недобросовісну сторону вчинити відповідні дії чи утриматись від них. Положення п.17 Принципів ООН з цього приводу зазначає, що у разі невиконання угоди, досягнутої в ході реституційного процесу, справу слід повернути на розгляд в реституційну програму або, якщо цього вимагає національне законодавство, на розгляд у рамках встановленого процесу кри- мінального правосуддя, i рішення щодо подальших дій має прийматися негайно. Схвалює закріплення цієї гарантії у національному законодавстві держав у своїй Резолюції № 2245 (2018) також і ПАРЕ, звертаючи увагу на заборону відмови від права на оскарження і можливість скасувати угоду за певних обставин [10].

\section{Висновки та перспективи подальших розвідок}

Таким чином, міжнародно-правові гарантії реалізації права на компроміс у кримінальному судочинстві - це положення міжнародно-правових актів, у яких закріплені правила обов'язкового та/або рекомендаційного характеру щодо діяльності органів державної влади та їх службових осіб, з метою забезпечення участі сторін у вирішенні кримінально-правового конфлікту шляхом застосування альтернативних (позасудових) примирювальних процедур.

Основними процесуальними гарантіями реалізації права на компроміс у кримінальному судочинстві, закріпленими на міжнародному рівні, є:

отримання юридичних консультацій сторонами щодо процедури примирення;

інформування учасників про основні аспекти відновних процедур;

- недопустимість примушування або схиляння сторін конфлікту 3 допомогою недобросовісних засобів до участі в процесах примирення або згоди 3 його результатами;

- забезпечення можливості повернення до розгляду кримінального провадження у межах встановленого процесу кримінального правосуддя у випадку недосягнення домовленості між сторонами у процесі процедур примирення;

- застосування кримінально-процесуальних санкцій до недобросовісної сторони у випадку виконання нею зобов'язань, взятих на себе за результатами примирення.

Дослідження зазначених міжнародно-правових гарантій реалізації особою права на компроміс у кримінальному су- 


\section{Кримінальне право, кримінальний процес та криміналістика}

дочинстві $є$ необхідною передумовою для подальших наукових розвідок 3 метою приведення у відповідність до них положень чинного кримінального процесуального законодавства України.

\section{1. Рішення $Е С П \lambda$ у справі} «Natsvlishvili та Togonidze проти Грузії» (Заява № 9043/05) від 29 квітня 2014 року. [Електронний ресурс]. - Режим доступу: http://hudoc.echr.coe.int/app/conversion/ $\mathrm{docx} / \mathrm{pdf}$ ? library $=\mathrm{ECHR} \& \mathrm{id}=001 \% 20$ 153730 \& file nam e = C A S E 20 O F \% $20 \mathrm{NATS}$ V L I S H V I L I \% 20 A N D \% 20 T O GO N I D E \% 20 v. \% 20 GEORGIA\%20-\%20\%5 B Ukrainian $\% 20$ Translation $\% 5 \mathrm{D} \% 2 \mathrm{By} \% 20$ the $\% 20 \mathrm{COE} \% 20$ Human\%20 Rights\%20 Trust\%20 Fund. pdf\&logEvent $=$ False

2. Трекке А. С. Кримінальне провадження на підставі угоди про визнання винуватості : Автореф. дис. ... канд. юрид. наук : 12.00.09 / А.С. Трекке. - Ірпінь, 2018. - 23 с.

3. Саєнко Г.Ю. Провадження на підставі угод у кримінальному процесі України: Автореф. дис. ... канд. юрид. наук: 12.00.09 / Г.Ю. Саєнко. - К., 2017. - 20 с.

4. Кокорев Л.Д. Общественные и личные интересы в уголовном судопроизводстве / под ред. А.Д. Кокорева. - Воронеж : Изд-во Воронеж. ун-та, 1984. - 159 с.

5. Горский Г.Ф. Проблемы доказательств в советском уголовном процессе / Г.Ф. Горский, А.Д. Кокорев,П.С. Элькинд. - Воронеж, Изд-во Воронеж. ун-та, 1978. - 303 с.

6. Стройкова А.С. Гарантии прав обвиняемого на предварительном следствии: Дисс. ... канд. юрид. наук: 12.00.09 / А.С. Стройкова. - Ростов-на-Дону, 2005. $-141 \mathrm{c}$.

7. Курс советского уголовного процесса. Общая часть / Алексеев В.Б., Алексеева А.Б., Божьев В.П., Бойков А.Д., и др.; Под ред.: Бойкова А.Д., Карпеца И.И. - М.: Юрид. лит., 1989. - 640 с.

8. Основні принципи застосування програм реституційного правосуддя в питаннях кримінального правосуддя. Резо- люція 2002/12 Економічної і Соціальної Ради від 24 липня 2002 р. [Електронний peсурс]. - Режим доступу: https://www. unodc.org/documents/justice-and-prisonreform/R_ebook.pdf

9. Рекомендація № R (99) 19 Комітету міністрів Ради Европи державам - членам Ради, які зацікавлені в організації медіації у кримінальних справах, прийнята Комітетом міністрів на 679-й зустрічі представників Комітету від 15 вересня 1999 р. [Електронний ресурс]. - Режим доступу: https://zakon.rada.gov.ua/laws/ show/994_828\#Text

10. Укладання угод у кримінальному провадженні: необхідність мінімальних стандартів для систем відмови від судового розгляду. Резолюція ПАРЕ №2245 (2018) від 12 жовтня 2018 р. [Електронний ресурс]. - Режим доступу: https:// www.echr.com.ua/document/rezolyuciyaparye-2245-2018/

11. Принципы и руководящие положения Организации Объединенных Наций, касающиеся доступа к юридической помощи в системах уголовного правосудия: резолюция, принятая Генеральной Ассамблеей 28 марта 2013, A/RES/67/187. [Електронний ресурс]. - Режим доступу: https:// ips.ligazakon.net/document/MU13168

12. Інструкція щодо кращого застосування чинної Рекомендації щодо медіації у кримінальних справах. Матеріали Европейської комісії 3 питань ефективного правосуддя від 7 грудня 2007 р. // Відновне правосуддя в Україні. - 2008. - № 3 (11). - C. 32-36.

13. Стосовно спрощення кримінального правосуддя. Рекомендація № $6 \mathrm{R}$ (87) 18 Комітету міністрів Ради Европи державам-членам від 17 вересня 1987 р. [Електронний ресурс]. - Режим доступу: https:// zakon.rada.gov.ua/laws/show/994_339\#Text

\section{INTERNATIONAL GUARANTEES OF THE RIGHT TO COMPROMISE IN CRIMINAL JUDICIARY}

The author of the article analyzes the main guarantees of the right to compromise, enshrined in international legal instruments. 


\section{АНОТАЦІЯ}

Автор статті аналізує основні гарантї реалізащї особою права на компроміс, закріплені у міжнародно-правових актах. На основі дослідження наукових праць розкривається поняття кримінальних процесуальних гарантій та їх характеристика. За результатами дослідження робиться висновок про те, шо міжнародноправові гарантї реалізащї права на компроміс у кримінальному судочинстві - це положення міжнародно-правових актів, у яких закріплені правила обов'язкового та/або рекомендаційного характеру щодо діяльності органів державной влади та їх службових осіб, з метою забезпечення участі сторін у вирішенні кримінально-правового конфлікту шляхом застосування альтернативних (позасудових) примирювальних процедур. Основна увага приділяеться таким гарантіям, як отримання юридичних консультаиій сторонами щзоо прочедури примирення; інформування учасників про основні аспекти відновних процедур; недопустимість примушування або схиляння сторін конблікту з допомогою недобросовісних засобів до участі в прочесах примирення або згоди з його результатами; забезпечення можливості повернення до розгляду кримінального провадження у межах встановленого процесу кримінального правосуддя у випадку недосягнення домовленості між сторонами у процесі процедур примирення; застосування кримінально-прощесуальних санкиій до недобросовісної сторони у випадку виконання нею зобов'язань, взятих на себе за результатами примирення. У статті звертається увага на роль правоохоронних органів у забезпеченні права на компроміс. Це пов'язано з тим, шо саме вони здійснюють втручання на ранніх етапах справи $i$, відтак, є першими, хто контактує з потерпілими та правопорушниками. Автор зазначає, що увага правоохоронних органів повинна бути приділена питанню направлення справи на процедуру примирення. Як суд, так і прокуратура мають бути повністю поінформовані про процедури примирення та бути свідомі щодо їх переваг та можливих ризиків. Це може досягатися через інформаиійні заходи, а також базові й чинні навчальні програми.

Ключові слова: міжнародний, гарантӥ, компроміс, примирення, правова допомога, інформування, конфлікт.
On the basis of research of scientific works the concept of criminal procedural guarantees and their characteristic is revealed. According to the results of the study, it is concluded that international legal guarantees for the exercise of the right to compromise in criminal proceedings are provisions of international legal acts, which enshrine mandatory and / or recommendatory rules on the activities of public authorities and their officials, in order to ensure the participation of the parties in resolving the criminal conflict by applying alternative (extrajudicial) conciliation procedures. The focus is on guarantees such as legal advice to the parties on the conciliation procedure; informing participants about the main aspects of recovery procedures; inadmissibility of forcing or inclining the parties to the conflict by unfair means to participate in the reconciliation process or agreeing with its results; ensuring the possibility of returning to criminal proceedings within the established criminal justice process in case of failure to reach an agreement between the parties in the process of conciliation procedures; application of criminal procedural sanctions to the unscrupulous party in case of fulfillment of the obligations undertaken as a result of conciliation. The article draws attention to the role of law enforcement agencies in ensuring the right to compromise. It is determined by their contacts with victims and offenders from the initial stages of criminal proceedings. The author notes that the attention of law enforcement agencies should be paid to the issue of referring the case to the conciliation procedure. Both the court and the prosecutor's office should be fully informed about conciliation procedures and be aware of their benefits and possible risks.

Key words: international, guarantees, compromise, reconciliation, legal assistance, information, conflict. 


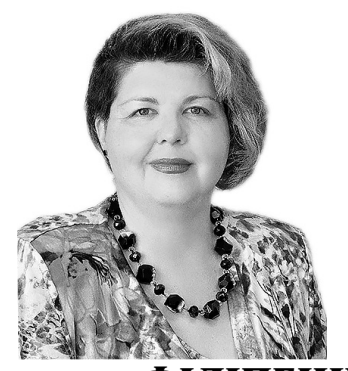

\section{КРИМІНОЛОГІЧНА ДІЯЛЬНІСТЬ І ПИТАННЯ ПРАВОВОГО ВИХОВАННЯ НАСЕЛЕННЯ}

ФІЛПЕНКО Наталія Свгенівна - кандидат юридичних наук, доцент (доцент кафедри права Національного аерокосмічного університету ім. М. С. Жуковського «Харківський авіаційний інститут»)

Orcid:https://orcid.org/0000-0001-9469-3650

УДК 343.9

DOI 10.32782/LAW.2020.3.23

Вступ
Співробітництво правоохоронних органів із засобами масової інформації (далі - ЗМІ), як показує практика, приносить в більшості випадків позитивні результати.

У сучасних умовах, що характеризуються різким загостренням криміногенної обстановки, взаємодія поліції, інших силових структур з мас-медіа вимагає негайної активізації. При цьому необхідно зосереджувати зусилля на особливо гострих напрямках, використовуючи найбільш ефективні форми i методи співпраці.

Якщо брати суто професійний аспект, то посилення співпраці зі ЗМІ прямо випливає iз вимог законів України: «Про державну підтримку засобів масової інформації та соціальний захист журналістів», «Про доступ до публічної інформації, «Про друковані засоби масової інформації (пресу) в Україні», «Про інформаційні агентства», «Про інформацію», «Про Національну раду України 3 питань телебачення і радіомовлення», «Про порядок висвітлення діяльності органів державної влади та органів місцевого самоврядування в Україні засобами масової інформації», Закон України «Про телебачення і радіомовлення», «Про телекомунікації» тощо. Так, Закон України «Про Національну поліцію» [1] прямо говорить про те, що громадська думка є головним мірилом ефективності діяльності органів поліції. При цьому головними завданнями вважаються: оперативність в діяльності підрозділів інформації і громадських зв'язків; виперед- ження в доведенні до населення правдивої та об'єктивної інформації про дії поліції; встановлення ефективних форм взаємодії 3 усіма $3 \mathrm{MI}$.

Аналіз останніх публікацій

Хоча окремі аспекти протидії злочинності, організації і здійснення кримінологічної діяльності висвітлені у працях таких вітчизняних та зарубіжних вчених, як О.М. Бандурки, С.С. Босхолова, М.Г. Вербенського, Е.О. Гладкової, В.В. Голіни, O.I. Гурова, О.М. Джужі, А.П. Закалюка, В.І. Кнорринга, О.Г. Колба, М.В. Корнієнка, О.М. Костенка Б.І. Краснова, О.М. Аитвака, О.М. Аитвинова, А.А. Музики, Ю.В. Орлова, В.М. Плішкіна, А.В. Савченка, С.В. Слінька, ᄉ.I. Спиридонова, В.А. Тимошенка, П.А. Фріса, О.Н. Ярмиша, Х.П. Ярмакі та інших науковців, роль 3МІ у цій діяльності не здобула належної уваги.

Відтак, з одного боку, визначення ролі засобів масової інформації у системі кримінологічної діяльності, а з іншого - способи взаємодії 3 ними 3 боку правоохоронних органів та інших владних інституцій, мають високий ступінь актуахьності.

Метою дослідження є визначення ролі ЗМІ у сфері кримінологічної діяльності, визначення можливостей співпраці у даній сфері та ідентифікація проблем, що виникають в межах такої співпраці. Само собою зрозуміло, що для виправлення становища повинні бути використані всі можливості, 
включаючи запозичення зарубіжного досвіду. Причому упор необхідно зробити на зусиллях превентивного, профілактичного характеру, на таких діях, які б перешкоджали спочатку розширенню негативних явищ, а потім сприяли їх зменшенню.

Звісно ж, що в цій справі найбільший ефект могло 6 дати щільна взаємодія правоохоронних структур з одного боку і ЗМІ - 3 іншого.

До речі, важливість широкого залучення мас-медіа до зусиль у протидії злочинності підкреслюється останнім часом фахівцями буквально всіх країн світу і найбільш авторитетних міжнародних організацій, включаючи ООН [2, с. 9]. При цьому зарубіжні експерти вказують, що система кримінального правосуддя може в даний час зіграти лише обмежену роль у запобіганні злочинності і тому пріоритетне місце відводять 3МІ, маючи на увазі, в першу чергу, просвітницьку роботу, направлений на запобігання злочинності. При цьому особливо підкреслюють, що дана робота вкрай необхідна в цілях підвищення рівня освіченості [3].

Крім того, широко обговорюються питання довгострокового впливу 3МІ в ці^ому у встановленні стандартів поведінки, зміни споживчих переваг і т. д. Деякі вчені стверджують, що більшість людей усвідомлюють такі поняття, як відхилення від норм поведінки і контроль, в першу чергу 3 телепередач. Інші дослідники вважають, що журналісти взагалі грають головну роль у формуванні уявлень про порядок, стабільність і зміни і впливають на практику самоконтролю, яка будується відповідно до цих уявлень [4].

Сьогодні практично всі визнають, що 3МI належить вирішальна роль в ознайомленні населення 3 найбільш значними факторами, у тому числі криміногенного штибу.

Питання полягає в тому, як впливають ці засоби на уявлення людей про злочинне. Переконані, якби всі виступи ЗМІ містили засудження злочинного, то це могло б мати ефект, зворотний бажаному. Тому потрібно говорити всю правду, включаючи відомості, прямо протилежні по суті. Адже в іншому випадку люди побачить протиріччя між тим, що вони бачать у реальному житті, і тим, що їм розповідають у ЗМІ. Ми ж спостерігаємо майже повну негнучкість офіційної влади, які змушують журналістів проводити інформаційну політику тільки одностороннього характеру, в чому нібито міститься небезпека обмеження свободи думок. Ба більше, дійшло до того, що комусь 3 чиновників прийшло в голову заборонити ряд видань і фільмів, які розповідають про потойбічну історію, популярних пісень на відповідну тематику і т. п. Тож, де та грань, що поділяє інформацію на застереження і пропаганду. Ми думаємо, якщо є свобода інформації, то не повинно бути ніяких обмежень. Саме так свого часу сталось і з наркотиками, коли під приводом дотримання права на свободу інформації та демократичні волевиявлення вітчизняні 3МІ виступили проти посилення антинаркотичних заходів в цілому і участі в цій справі преси.

Не треба мати спеціальних навичок, аби віднайти зараз інформацію про наркотики. Серед джерел найбільш доступної інформації про номенклатуру наркопрепаратів, їх придбання, виготовлення, використання i т. д. чільну роль у нас грають засоби масової інформації. Очевидним лідером є інтернет, за ним слідують такі комунікаційні канали, як телебачення, радіомовлення, відеопродукція, друк.

Молодь і студентство черпають відомості про наркотичні речовини 3 WEB-сторінок мережі інтернет, а деяка частина - в процесі комп'ютерних ігор. У громадських місцях, навчальних закладах, на дискотеках тощо молоді люди діляться адресами інформаційних джерел, тобто обмінюються відомостями.

Очевидно, що будь-яке адміністративне перекриття описаних вище каналів поки що технічно неможливо, з одного боку, в силу їх численності і різноманітності, а з іншого, через нестачу коштів для організації подібних заходів протидії. Тому теза про введення якоїсь «цензури» 3 боку влади, про яку йшлося вище, є надуманою і, як вже згадувалося, використовується в явно зловмисних цілях.

Засоби масової інформації, з огляду на їх величезну щоденну аудиторію, можуть вне- 


\section{Кримінальне право, кримінальний процес та криміналістика}

сти істотний внесок у справу протидії 3лочинності.

Встановлюючи ділові контакти $з$ працівниками телебачення, радіо, газет, журналів, інтернет-видань і надаючи їм необхідну інформацію про стан криміногенної ситуації, необхідно домагатися, щоб в основі повідомлень лежала об'єктивність, а не сенсаційність. Цілком ймовірно, що саме прагнення до сенсацій, бажання кинути виклик суспільству і необхідність підвищити рейтинг і пояснюють той факт, що деякі телевізійні компанії, газети, інтернет-портали передають значно більше перекрученої інформації, ніж інформації, в якій розглядаються наслідки такої політики і пов'язана з цим шкода.

Використовуючи величезний потенціал ЗМІ слід проводити заходи у сфері профілактики і освіти [5, с. 150-154], спрямовані на об'єктивне інформування широкої громадськості, що сприятиме формуванню більш раціонального підходу до проблем і дозволить уникнути сенсаційності.

При цьому правоохоронцям слід враховувати, що представники ЗМІ, які спеціалізуються на кримінальних проблемах, повинні в них розбиратися. Для цього необхідно активно співпрацювати з:

- керівниками друкованих видань (газет, журналів і т. п.), інтернет-медіа, в яких створюються постійні рубрики з відповідних проблем;

- журналістами і кореспондентами, що спеціалізуються на зазначеній тематиці;

- адміністрацією регіону та органів місцевого самоврядування, яким слід запропонувати цикли передач із залученням правоохоронців, експертів, науковців, педагогів, психологів, медичних працівників і т. д.;

- громадськими лідерами, акторами, музичними та спортивними діячами, які пропагують нормальний спосіб життя.

Тактика, заснована на використанні засобів масової інформації, становить лише частину стратегії протидії злочинності.

у підготовчих матеріалах до Дев'ятого Конгресу ООН по боротьбі зі злочинністю та поводження зі злочинцями [6] пропонується ширше використовувати так званий «соціальний маркетинг», тобто сприяти шляхом надання матеріалів і порад поши- ренню позитивних поведінкових моделей. Використовувана при цьому методика [7, с. 74-77] може бути спрямована на проведення дискусій, поширення інформації, надання впливу на взаємини, систему цінностей і створення клімату, сприятливого для подолання зловживань і протиправних дій. Зовсім не обов'язково, щоб «соціальний маркетинг» сам по собі вів до зміни моделей поведінки, він може змінювати сприйняття, ставлення і думки, що також йде на користь антикримінальній моделі державної політики, іiї стратегії і тактиці.

Що стосується поліції, то вона, як особливо підкреслюється в документах Дев'ятого Конгресу ООН, може відігравати важливу роль також у справі визначення характеру інформації для 3МІ. У багатьох країнах представники преси звертаються до поліції за відомостями про вчинені злочини. Форма надання поліцією відповідних відомостей часто визначає характер просування їх в суспільно-політичні кола і певною мірою реакцію населення на ту чи іншу подію і супутні обставини.

В принципі початковий етап пропагандистських дій добре знайомий майже кожному, адже це лише передача певної інформації в будь-якій формі (усній, письмовій, графічній, образотворчій і т. д.) [8, c. 61]. На жаль, найчастіше кампанія цим i обмежується, і тому їі ККД, як правило, буває досить невисокий, а то і взагалі нульовий (у тому випадку, якщо інформація залишиться, як то кажуть, під сукном). Якщо ж просування повідомлення носить сенсаційний відтінок, то його можуть підхопити, поширити інші, не причетні особи; хтось із них прокоментує, доповнить сам, хтось спотворить первинний матеріал до невпізнання. Захід почне розвиватися стихійно і може навіть призвести до протилежного, не запрограмованого результату (особливо, якщо до нього підключаться інтернет-боти [9]).

Щоб домогтися серйозного (цільового) результату, важливо кампанію заздалегідь спланувати і здійснити за задуманою схемою, в якій слід врахувати фактор часу (початок, розвиток, завершення кампанії), місце, передбачити паузи, підкріплення, 
коригування тощо. Для цього, як мінімум необхідні:

- власне інформація (первинна, розвиваюча, підкріплююча, заключна);

- засоби інформації, які гарантовано будуть брати участь у виконанні розробленого плану;

- зворотний зв'язок (збір та аналіз відомостей про вплив на громадськість просунутих матеріалів, їх подальше поширення серед населення).

Зі сказаного виходить, що здійснення ефективної пропагандистської кампанії вимагає ретельної підготовки, а також кваліфікованих виконавців. Ці дві умови взаємопов'язані і при відповідальному підході можуть бути дотримані у максимальній мipi.

Робота з реалізації акцій проводиться за тими ж параметрами, що викладені у попередній частині, і має лише регіональну специфіку.

Слід мати на увазі, що у невеликому місті, декількох населених пунктах при значній їх віддаленості один від одного особливу роль відіграють місцеве телебачення і радіо, менше - інтернет, майже не доступні друковані 3MI.

На місцях значно складніше, ніж на державному рівні, отримати необхідну інформацію, підібрати відповідні за задумом акції органи преси і головне, - там може не бути кваліфікованих співробітників. У зв'язку 3 цим розробку, планування і реалізацію акції в регіоні бажано проводити із залученням фахівців регіонального рівня, науковців (наприклад, в якості консультантів, використовуючи для цього телефонний або інший зв'язок).

3 іншого боку, в регіонах здійснення акцій є більш легкою справою, ніж на державному рівні. В окремому місті керівні працівники правоохоронних органів і преси, як правило, підтримують найтісніші повсякденні контакти і швидше знаходять спільну мову. Внаслідок частого спілкування вони можуть легше погоджувати акції і коригувати їх хід.

Необхідно відзначити і ту обставину, що в областях, регіонах, на прикордонних територіях вплив проведеної акції на населен- ня може бути більш значним, ніж у центрі, адже там дуже уважно ставляться до повідомлень місцевих 3МІ та виказують їм більшу довіру.

Якщо говорити про просвітницькі кампанії, то вони повинні проводитися постійно. Їх посилення або послаблення може бути пов'язано лише 3 особливостями сприйняття населенням, сезонними факторами (наприклад, літні канікули) та іншими моментами. У такої кампанії мають брати участь медики, науковці, вихователі, правоохоронні, експертні та інші держустанови, громадські організації, популярні діячі мистецтва і практично всі 3МІ (телебачення, кіно, радіо, комп'ютерні мережі, реклама, наочна агітація і т. д.), а так само книговидання (книжкова продукція).

Однак оскільки в компетенцію правоохоронних органів не входить організація настільки широких кампаній (що, тим не менш можливо), розглянемо лише можливості специфічного характеру.

Пропагандистську кампанію 3 даної тематики, у тому числі на місцях, треба починати 3 загальної постановки завдання. Необхідно скласти докладний план, в якому визначити приблизний часовий період проведення заходу, задіяні сили, рядових виконавців і відповідальних за всю роботу керівників. У плані має бути чітко відображено, з яких джерел і коли надходить відповідна інформація, як обробляється і дозується, в яких формах просувається; які органи інформації, а також інші засоби, і коли підключаються до участі. Одночасно слід передбачити географію і час здійснення етапів, аналіз ефективності вже здійсненої роботи та відповідне коригування, зумовлене новими обставинами (успіх, неуспіх, перешкоди, несподіванки і т. п.).

Резюмуємо: для організації та проведення широкої пропагандистської діяльності необхідно врахувати велику кількість факторів, розраховувати кваліфікованими фахівцями і виконавцями, яких потрібно навчати і спрямовувати на цю роботу в повсякденному режимі.

Із наведеного вище, можемо зробити низку висновків. 


\section{Кримінальне право, кримінальний процес та криміналістика}

1. Криміногенна ситуація останнім часом суттєво ускладнилася через різні причини, у тому числі соціально-економічні.

2. В умовах погіршення криміногенної ситуації і обстановки все більшої актуальності набуває профілактична діяльність у даній сфері. Враховуючи, що засоби масової інформації у сучасному світі мають суттєвий вплив на погляди і свідомість суспільства, забезпечення тісної взаємодії правоохоронних органів зі ЗМІ є однією з передумов проведення ефективної кримінологічної діяльності. При цьому, слід вести мову саме про взаємодію, а не контроль, адже адміністративні заходи із цензурування інформації, скоріше за все, матимуть негативний ефект, 3 огляду на вільне поширення інформації у сучасному світі.

3. Інформаційні кампанії у 3МІ мають бути спрямовані передусім на об'єктивне, повне та правдиве інформування, а також сприяти формуванню позитивних поведінкових моделей, системи цінностей, орієнтованих на нормальний спосіб життя.

4. Підготовка інформаційних кампаній мають включати не лише підготовку інформаційних матеріалів, але й підбір ефективних каналів поширення, забезпечення дієвого зворотного зв'язку.

\section{Література}

1. Про Національну поліцію : Закон України. Відомості Верховноӥ Ради. 2015. № 40-41. Ст. 379.

2. Прохорова М.ᄉ. Наркотизм: уголовно-правовое и криминологическое исследование. СПб.: Юридический центр Пресс, 2002. 287 c.

3. Негодченко О.В. Організаційноправові проблеми забезпечення прав i свобод людини під час розкриття злочинів, пов'язаних з наркобізнесом. Науковий вісник Юридичної академї Міністерства внутрішніх справ: Збірник наукових праць. 2003. Спеціальний випуск № 1 (13). С. 5-11.

4. Бугера О. I. Проблеми використання засобів масової інформації для запобігання злочинів серед неповнолітніх : автореф. дис. на здобуття наук. ступеня канд. юрид. наук : 12.00.08. Київ, 2006. - 20 с.
5. Абетка медіа/за загал. ред. В. Ф. Іванова; переклад з нім. В. Климченка. Київ : Академія української преси, Центр вільної преси, 2015. 177 с.

6. Жаровська Г.П. Міжнародно-правові засади боротьби з транснаціональною злочинністю: проблеми й перспективи. URL: http://intlawalmanac.net/v6/13.pdf (дата звернення 02.10.2020).

7. Журналістський фах: газетно-журнальне виробництво : навчальний посібник/ за ред. В. В. Різуна. 2-ге вид., перероб. і доп. Київ : Видавничо-поліграфічний центр «Київський університет», 2012. 352 с.

8. Пределы правового пространства свободы прессы (российские споры с участием СМИ в контексте мировой практики) : сборник статей. Юристъ за конституицоннъе права и свободъл/сост., отв. ред. и авт. вступ. ст. А. К. Соболева. Москва : Новая юстиция, 2008. - 272 с.

9. Вільям Ф. Мережі і мережеві війни: майбутне терору, злочинності та бойових дій/за ред. Дж. Арквілли, Д. Ронфельдта. Iнбормаційний бюлетень Міжвідомчого науководослідного центру з проблем боротьби з організованою злочинністю. 2006. № 5. С. 52-61.

Filipenko Natalia

PhD in Law, Associate Professor (Associate Professor of Law, ME Zhukousky National Aerospace University "Kharkiv Aviation Institute")

CRIMINOLOGICAL ACTIVITY AND QUESTIONS OF PEOPLE LEGAL EDUCATION

The purpose of the paper is to examine role of mass media in combating crimes, together with the opportunities of cooperation between the police and the mass media in combating crimes and main problems arising from such cooperation. Results of the study allows us to draw several conclusions. Firstly, we underscore that there is a significant increase of crimes. Under these circumstances, prevention-oriented approach to combating crimes gains special significance. Secondly, role of the mass media in shaping public perceptions of certain issues makes them a necessary partner for the law enforcement agencies in deterring spread of crimes. Thirdly, there are significant 


\section{АНОТАЦІЯ}

у статті розглянуто роль засобів масової інбормачиї у протидї злочинності, організаизї та здійсненні кримінологічної діяльності, а також проблеми, що виникають в рамках такої взаємодї в Украӥні. Зроблено висновок про важливість, передусім, превентивних заходів, направлених на обмеження можливостей вчинення злочинів та ключову роль засобів масової інформачиї у иій діяльності, передусім через організачію спільних з правоохоронними та іншими органами влади інформаційних кампаній.

Ключові слова: правоохоронні органи, засоби масової інформациі, інформаиійні кампаніӥ, злочинність, кримінологічна діяльність.

problems arising from the fundamentally different interests of the mass media and the police, which requires the latter to seek ways to align their activities. Still, we see cooperation as the only way to succeed, as administrative measures, such as censorship, will be largely coun- terproductive in the age of high availability of the information. Practical implications of the study lie in the recommendations for the activities of the police aimed at ensuring efficient cooperation with the mass media in organizing informational campaigns, promoting healthy lifestyle and so on. We stress upon necessity of the well-planned campaign, including not only careful preparation of the information, but also selection of the most efficient channels of dissemination and setting up of the feedback in order to objectively appraise their results and to allow a certain level of flexibility in adapting and adjusting these campaigns to the circumstances. We also underscore importance of careful selection of the partners in mass media, so that both sides of the partnership have a deep understanding of the issue they are working with. Lastly, we investigate features of the information campaigns on the local level.

Key words: law enforcement agencies, mass media, information campaigns, crimes, criminological activity. 


\title{
ВЕКТОРИ РЕФОРМУВАННЯ НОТАРІАЛЬНӦ̈ ДІЯЛЬНОСТІ: ОКРЕМІ ЦИВІЛЬНО-ПРАВОВІ ТА КРИМІНАЛЬНО-ПРАВОВІ АСПЕКТИ
}

\begin{abstract}
ОРТИНСЬКИЙ Володимир Львович - доктор юридичних наук, професор, директор Навчально-наукового інституту права, психології та інноваційної освіти Національного університету «Львівська політехніка», Заслужений юрист України ORCID ID: 0000-0001-9041-6330

УДК 340.134

DOI 10.32782/LAW.2020.3.24
\end{abstract}

Статья посвящена анализу базовъхх положений Закона Украинъ «О нотариате», в том иисле норм, которыле были изложены в первоначальной редакиии от 2 сентября 1993 года. Сделан сравнительный анализ с последующими изменениями и дополнениями. Рассмотренъи тендениии законодательного обеспечения нотариальной деятельности в переходный период от тотального государственного администрирования, обретения независимости Украинъ к стандартам европейского (латинского) нотариата в государстве.

Ключевъе слова: нотариус, нотариальная деятельность, присяга нотариуса, нотариальная тайна, нотариальнъй округ.

\section{Постановка проблеми}

Історично доведено, що нотаріальна діяльність розвивалася тільки у площині публічної юрисдикції, діяльність, як одна 3 базових інститутів громадянського суспільства, що патронує захист, недоторканність приватної власності, протекцію усіх майнових, інтелектуальних прав і законних інтересів фізичних та юридичних осіб, які звернулися по вчинення нотаріальних дій. Одночасно, така діяльність має і попереджувальне, превентивне забарвлення у форматі системи здійснюваних публічних дій, скерованих на юридичне закріплення безспірних цивільних прав і фактів, тобто результатом якої завжди є посвідчення прав, фактів, що мають юридичне значення.

В Україні сформувалася багатовікова історія діяльності нотаріальних органів.
Умовно можна виокремити наступні етапи становлення та розвитку: у Київській Русі (IX - XII сторіччя), у Галицько-Волинській державі (1199 - 1349 рік), на українських землях у складі Великого князівства Литовського (1340 - 1659 рік), на українських землях у складі Польського Королівства (1387 - 1569 рік) та Речі Посполитої (1569 - 1772 рік). Нотаріальна діяльність в Українській Козацькій державі (1649 - 1783 рік), на українських землях у складі Російської імперії (1783 - 1917 рік), у складі Австрійської та Австро-Угорської імперій (1772 1918 рік), на західноукраїнських землях у складі Польщі (1921 - 1939 рік), в радянській Україні протягом 1917 - 1990 років, у незалежній Україні протягом новітнього періоду.

У представленій публікації зроблено спробу звернутися саме до новітньої істоpiї, тих, здебільшого прогресивних тенденцій розвитку, які мали місце у попереднє десятиріччя, на початку становлення і незалежності України і нотаріального права, законодавства, зокрема.

\section{Стан дослідження}

у своїх наукових пошуках, багато вчених зверталося до питань правового регулювання нотаріальної діяльності, під кутом бачення історико - правової реальності, у площинах конституційного, цивільного та кримінального права, криміналістики, інших галузей знань. Зокрема, до них належать: Т. Аверьянова, I. Аршава, 
П. Андрушко, В. Баранкова, Д. Бараненко, М. Башта, В. Бездрабко, I. Безклубий, Р. Бєлкін, А. Білецький, С. Благовісний, В. Бліхар, I. Бойко, О. Бочан, О. Бунчук, Я. Брайнін, М. Василенко, Т. Варфоломеєва, О. Вінниченко, А. Вінберг, О. Вовк, М. Владимирський-Буданов, М. Гетьманчук, В. Глиняний, Ю. Гошко, В. Гончаренко, Б. Греков, В. Громов, В. Грищук, Г. Грамович, А. Грановський, I. Грозовський, А. Гуледза, П. Гураль, Г. Гулєвська, А. Данюк, Г. Демиденко, М. Демкова, О. Дзера, М. Долинська, Р. Достдар, А. Дячук, М. Дякович, В. Єрмолаєв, Н. Сфремов, А. Єфіменко, Д. Забзалюк, Ю. Заіка, П. Захарченко, Б. Здравомислов, Ю. Золотухін, С. Ізосімов, А. Іщенко, Н. Ільєва, М. Кальницький, М. Кобилецький, Ю. Козьяков, О. Коротюк, А. Кольбенко, В. Комаров, В. Комаров, В. Колесник, Р. Кочерьянц, Н. Клименко, В. Кульчицький, Р. Аащенко, Ф. Аеонтович, П. Аепісевич, В. Аисиченко, В. Макарчук, Х. Майкут, В. Марченко, Р. Максимович, С. Місевич, О. Михайленко, В. Навроцький, М. Настюк, Ю. Нікітін, О. Нелін, М. Никифорак, О. Новаков, М. Оздоєв, С. Орач, Ю. Орзіх, В. Павлов, I. Паньонко, С. Пасічник, Б. Петришак, Н. Пінчук, О. Підопригора, $\curlywedge$. Радзієвська, В. Рубаник, О. Росинська. М. Салтевський, М. Сегай, С. Семенов, Б. Совенко, В. Степаненко, А. Стрижевська, М. Страхов, І. Терлюк, В. Терентьєв, Б. Тищик, А. Ткач, Г. Трофанчук, I. Усенко, В. Устименко, C. Фурса, E. Фурса, Г. Федущак-Паславська, I. Фріс, С. Харитонов, О. Харитонова, В. Харченко, В. Хашев, Н. Хома, В. Черниш, Р. Шандра, В. Шатіло, В. Шепітько, Ю. Шиндель, О. Шевченко, Ю. Шемшученко Д. Яворницький, А. Яковлів та інші.

\section{Мета дослідження}

Провести фрагментарний моніторинг (тобто у межах дозволеного обсягу наукової публікації), теоретичних і методологічних засад, світоглядних основ процесу подальшого становлення, удосконалення вітчизняного законодавства про нотаріальну діяльність, у контексті сучасних доктрин, які втілювалися у вже новітній період, за попереднє десятиріччя.

\section{Виклад основного матеріалу}

Початок дев'яностих років минулого сторіччя ознаменувався також початком становлення не лише суверенітету та незалежності держави, а й усіх економічних, політико - правових процесів.

3 переходом суспільства до ринкових відносин, законодавчим визнанням рівноправності всіх форм власності, розвитком підприємницької діяльності і процесів приватизації, стало очевидним, що державний нотаріат втрачає своє значення і не може повністю виконувати покладені на нього функції. Поява значної кількості приватних власників передбачає постійний перерозподіл власності, зокрема нерухомості. Із прийняттям, свого часу, Закону «Про власність» та деяких інших, зокрема Закону України «Про заставу», значно розширилася компетенція державних нотаріусів, збільшилась кількість і обсяг нотаріальних дій. Таким чином, формування ринкових відносин обумовило також необхідність проведення радикальної реформи органів нотаріату, який є однією з ланок правової системи. Роль нотаріату в правовому забезпеченні економічних відносин підтверджується світовою практикою. Від якості діяльності нотаріату залежить нормальне функціонування цивільного обороту держави, ефективність охорони і захисту майнових прав та законних інтересів громадян та інших суб’єктів господарювання [1].

Як слушно стверджує А. Давиденко, історія розвитку і реформування нотаріату сучасної незалежної України тісно переплітається з історією двох великих подій, які дали змогу українським нотаріусам самостійно вирішувати свою долю, - прийняття Закону України «Про нотаріат» та заснування Української нотаріальної палати - єдиного всеукраїнського об'єднання нотаріусів (створена 22 квітня 1993 року на конференції нотаріусів та згодом зареєстрована як громадське об'єднання в Міністерстві юстиції України). Ці події суттєво вплинули на життя нотаріату, адже як інститут, який функціонує у сфері перетину приватних i публічних інтересів, нотаріат має володіти організаційною структурою, що відповідала 6 його унікальній природі [2]. 


\section{Цивільне, підприсмницьке, господарське та трудове право}

Прийнятий Верховною Радою України 2 вересня 1993 року Закон України «Про нотаріат» можна порівняти 3 епохальною подією в діяльності нотаріату. Він був фундаментом нотаріальної реформи та чітким вектором для українського нотаріату у бік європейського (латинського) нотаріату.

Хоча на території Західної України ще до 1993 року був відомий інститут приватного нотаріату, загалом можна поділити думку проф. Ю. Козьякова про те, що закон створив правові підстави для впровадження принципово нових, раніше не відомих нашому законодавству інститутів (зокрема приватної нотаріальної діяльності), який уже протягом століть існує у багатьох зарубіжних країнах і показав себе з кращого боку. Розроблений з урахуванням досвіду зарубіжних країн, які визнають латинську школу нотаріату (Німеччина, Франція, Італія тощо), чинний закон реально посилив роль нотаріату у суспільному житті незалежної Української держави, зробив фігуру нотаріуса в системі правозастосування ще вагомішою, підняв на більш високий щабель престиж цієї, без сумніву, цікавої юридичної професії [3].

Вказаний нормативний акт забезпечив перехід від радянського нотаріату до незалежного українського нотаріату. Зокрема, увібрав у себе найкращий світовий досвід щодо здійснення нотаріусами публічно-правової діяльності, зумовив суттеве збільшення кількості приватних нотаріусів, сприяв більшому доступу фізичних та юридичних осіб до нотаріального забезпечення, ввів поняття відповідальності нотаріусів, тобто зупинення і припинення їхньої діяльності у разі допущення порушень тощо [1, с. 294].

Так, Кримінальний кодекс України був доповнений регламентацією стосовно відповідальності за кримінальні правопорушення вчинені нотаріусом. Стаття $232^{1}$ КК України передбачає відповідальність за незаконне використання нотаріусом інсайдерської інформації; стаття 358 КК України, за підроблення нотаріусом документів, печаток, штампів та бланків, збут чи використання підроблених документів, печаток, штампів; стаття $365^{-2}$ КК України, за зловживання повноваженнями особами, які надають публічні послуги, з метою отримання неправомірної вигоди, якщо це завдало істотної шкоди охоронюваним законом правам або інтересам окремих громадян, державним чи громадським інтересам або інтересам юридичних осіб; ч.3 статті $368^{-4}$ КК України, за прийняття пропозиції, обіцянки або одержання нотаріусом неправомірної вигоди для себе чи третьої особи за вчинення дій або бездіяльність 3 використанням наданих їй повноважень в інтересах того, хто пропонує, обіцяє чи надає таку вигоду, або в інтересах третьої особи.

Нові принципи нотаріальної діяльності, які були закладені цим Законом, дали змогу вирішити організаційні проблеми стосовно нотаріального забезпечення суб'єктів цивільно-правових відносин та практично зняти державі із себе більшість організаційних питань і матеріальних витрат у цій сфері [4].

Ще до нових редакцій (відповідно, у 2008, 2015 та 2020 році) самої назви та змісту статті 1 Закону України «Про нотаріат», законодавець визначив власне поняття нотаріату, як систему органів і посадових осіб, на які покладено обов'язок посвідчувати права, а також факти, що мають юридичне значення та вчиняти інші нотаріальні дії, передбачені Законом, з метою надання їм юридичної вірогідності [5]. Таким чином, законодавцем у вже згаданій статті, встановлено вичерпний перелік суб'єктів, які мають право вчиняти нотаріальні дії: нотаріуси, які працюють у державних нотаріальних конторах, державних нотаріальних apхівах (державні нотаріуси) або займаються приватною нотаріальною діяльністю (приватні нотаріуси), у сільських населених пунктах нотаріальні дії, також вчиняються уповноваженими на це посадовими особами органів місцевого самоврядування.

Органи, які вправі вчиняти нотаріальні дії, загальновизнано диференціювати на інститути нотаріату (державні та приватні нотаріуси) та квазі-нотаріату (посадові особи органів місцевого самоврядування, інші посадові особи, на які покладено вчинення окремих видів нотаріальних дій відповід- 
но до законодавства). Так, згідно зі статтею 37 Закону, було визначено, що у сільських населених пунктах уповноважені на це посадові особи органу місцевого самоврядування вчиняють нотаріальні дії, зокрема, вживають заходів щодо охорони спадкового майна; посвідчують заповіти (крім секретних); видають свідоцтва про право на спадщину та інші [5].

Важливою властивістю Закону (стаття 34) було чітке окреслення нотаріальних дій, що можуть вчиняти саме нотаріуси. Згодом, у 2012, 2017, 2019 та 2020 роках, цей перелік був доповнений чи деталізований [5].

Порівняльний аналіз повноважень нотаріальних дій, що можуть вчиняти нотаріуси сучасної України за Законом «Про нотаріат» 1993 року та державних нотаріальних контор радянського періоду (ст. 13 Закону УРСР «Про державний нотаріат» 1974 року) призводить до підсумку, що у своїй масі, за кількістю та змістовно-правовим наповненням, вони [повноваження] є однотипними.

Наступним прогресивним постулатом тоді прийнятого Закону було те, що опосередком положень статті 38 (з наступними редакціями у 2003, 2012, 2020 роках), утверджувалася реальна самостійність, незалежність держави. Закон делегував вчинення певних нотаріальних дій до компетенції консульських установ України [5].

Перелік повноважень консульських установ України за Законом України «Про нотаріат» 1993 року, загалом, корелюється 3 переліком нотаріальних дій, що вчиняли консульські установи СРСР (ст. 15 Закону УРСР «Про державний нотаріат» 1974 року (16 видів дій)).

Також Закон встановив права та обов'язки нотаріусів, механізм їх призначення на посаду, відомчу підлеглість.

Новою нормою законодавства стало положення ст. 3 Закону України «Про нотаріат», яке регулює порядок доступу до професії нотаріуса (з наступними змінами та доповненнями у 2012, 2015, 2016, 2019 та 2020 році). Нотаріусом може бути громадянин України, якому присуджено ступінь вищої юридичної освіти не нижче магістра, який володіє державною мовою відповідно до рівня, визначеного Законом України «Про забезпечення функціонування української мови як державної», має стаж роботи у сфері права не менш як шість років, з них помічником нотаріуса або консультантом державної нотаріальної контори - не менш як три роки, склав кваліфікаційний іспит і отримав свідоцтво про право на зайняття нотаріальною діяльністю. Не може бути нотаріусом особа, яка має судимість за вчинення злочину, якщо така судимість не погашена або не знята у встановленому законом порядку (крім реабілітованої особи), особа, дієздатність якої обмежена, або особа, визнана недієздатною [5].

Відповідно до Постанови Верховної Ради України «Про порядок введення в дію Закону України «Про нотаріат» від 2 вересня 1993 р. (п. 3) було встановлено, що без стажування і складання кваліфікаційного іспиту до нотаріальної діяльності допускаються нотаріуси, які на день вступу в силу Закону України «Про нотаріат» (1 січня 1994 року) працювали у державних нотаріальних конторах, а також посадові особи Міністерства юстиції України, управлінь юстиції Ради Міністрів Республіки Крим, обласних, Київської і Севастопольської міських державних адміністрацій, робота яких безпосередньо пов'язана 3 керівництвом та контролем за діяльністю нотаріату.

Реєстрацію приватної нотаріальної діяльності провадили Міністерство юстиції Республіки Крим, управління юстиції обласної, Київської і Севастопольської міських державних адміністрацій. Згодом втратили чинність накази Міністерства юстиції України «Про затвердження Положення про порядок заміщення приватного нотаріуса», «Про затвердження Положення про порядок реєстрації приватної нотаріальної діяльності» та інші. У 2011 році наказом Міністерства юстиції України затверджене нове «Положення про порядок реєстрації приватної нотаріальної діяльності та заміщення приватного нотаріуса» (із змінами від 27.02.2020 року) [6]. 


\section{Цивільне, підприсмницьке, господарське та трудове право}

Нотаріальний округ визначався управлінням юстиції, а робоче місце приватного нотаріуса мало розташовуватися у межах визначеного для нього нотаріального округу. Законодавцем було встановлено обов’язок для приватних нотаріусів приступити до виконання своїх обов'язків на протягом трьох місяців від дня отримання реєстраційного посвідчення, а також укласти договір службового страхування чи внести страхову заставу для забезпечення відшкодування ймовірної шкоди, завданої клієнтам своїми незаконними діями або недбалістю у розмірі стократної мінімальної заробітної плати [6].

Законодавець наділив нотаріусів доволі широким колом прав, які передбачив у статті 4 Закону «Про нотаріат» (доповнена згодом у 2008, 20122015 та 2020 році) [5].

Вагомим доказом рівності між державними та приватними нотаріусами, видається, є положення ст. 6 Закону щодо складання нотаріальної присяги. Особа, якій вперше надається право займатися нотаріальною діяльністю, у відповідному територіальному органі Міністерства юстиції України в урочистій обстановці складає присягу.

Збереженню нотаріальної таємниці, тобто сукупності відомостей, отриманих під час вчинення нотаріальної дії або звернення до нотаріуса заінтересованої особи, в тому числі про особу, піi майно, особисті майнові та немайнові права і обов'язки, законодавцем присвячено окрему ст. 8 Закону.

Від своєї первинної редакції, стаття отримала цілу низку змін та доповнень, останні $з$ яких відбулися прийнятими Законами України «Про внесення змін до деяких законодавчих актів України щодо забезпечення ефективності інституційного механізму запобігання корупції» від 2 жовтня 2019 року та «Про внесення змін до Закону України «Про нотаріат» щодо усунення законодавчих колізій та прогалин» від 14 липня 2020 року.

Нотаріусом протягом десяти робочих днів на обгрунтовану письмову вимогу суду, прокуратури, органів, що здійснюють оперативно-розшукову діяльність, органів досудового розслідування у зв'язку з кримінальним провадженням, цивільними, господарськими, адміністративними справами, справами про адміністративні правопорушення, що знаходяться в провадженні цих органів, 3 обов'язковим зазначенням номера справи та прикладенням гербової печатки відповідного органу, а також на обгрунтовану письмову вимогу державного виконавця, приватного виконавця за виконавчим провадженням 3 обов'язковим зазначенням номера виконавчого провадження та реквізитів виконавчого документа, на підставі якого здійснюється виконавче провадження Національному агентству $з$ питань запобігання корупції на його письмовий запит, здійснений з метою виконання повноважень, визначених Законом України «Про запобігання корупції». Довідки про суму нотаріально посвідчених договорів, які необхідні виключно для встановлення додержання законодавства 3 питань оподаткування, надаються нотаріусом протягом десяти робочих днів на обгрунтовану письмову вимогу податкового органу, засвідчену гербовою печаткою такого органу [7].

Також важливе значення для здійснення нотаріальної діяльності мали нормист. 98 Закону України «Про нотаріат», згідно 3 якими нотаріуси застосовують норми іноземного права відповідно до законодавства України, міжнародних договорів. Нотаріусам дозволено приймати документи, складені відповідно до вимог іноземного права, та робити посвідчувальні написи за формою, передбаченою іноземним законодавством, у випадку, якщо це не суперечить законодавству України [5].

\section{Висновки}

Закон України «Про нотаріат», без перебільшення, можна вважати «історичною віхою» для подальшого розвитку, модернізації системи органів, які вчиняють нотаріальні дії; для галузі права; для галузі законодавства та, звісно, для науки, навчального процесу, зокрема.

Закон сприяв безперешкодному доступу громадян до нотаріального забезпечення, корелював повноваження державних 


\section{АНОТАЦІЯ}

Стаття присвячена аналізу базових положень Закону України «Про нотаріат», у тому числі норм, які були викладені у первинній редакиіӥ від 2 вересня 1993 року. Зроблено порівняльний аналіз із наступними змінами та доповненнями. Розглянуто тенденциї законодавчого забезпечення нотаріальної діяльності у перехідний період від тотального державного адміністрування, здобуття незалежності України до стандартів європейсъкого (латинсъкого) нотаріату в державі.

та приватних нотаріусів у вчиненні нотаріальних дій, підвищив професійні вимоги, посилив гарантії діяльності нотаріуса та правового режиму нотаріальної таємниці. Забезпечив реалізацію конституційної норми щодо судового контролю за законністю вчинених нотаріальних дій, окреслив інститут відповідальності нотаріусів, тобто зупинення і припинення їхної діяльності у разі допущення порушень.

\section{Мітература}

1. Долинська М. Становлення та розвиток законодавства про нотаріальну діяльність в Україні: дис. ... докт. юрид. наук: 12.00.01 / Львівський національний університет імені Івана Франка. Аьвів, 2017. C. $290-291$.

2. Давиденко А. О. Історія виникнення нотаріату в Україні. Вісник Запорізъкого національного університету. 2010. № 4. С. 23 - 28.

3. Козьяков Ю. М. Нотаріат. Історія i сучасність (короткий огляд). Нотаріат для Bac. 1998. № 1. С. $13-16$.

4. Шишленко В. Г. Щодо реформування нотаріату України. Форум права. 2012. № 1 . C. $1092-1098$.

5. Про нотаріат: Закон України від 02.09.1993. База даних «Законодавство України». Верховна Рада України. URL: https://zakon.rada.gov.ua/laws/show/3425-12.

\section{SUMMARY}

The article is devoted to the analysis of the basic provisions of the Law of Ukraine 'On the notary', including the norms, which were set out in the original version from September 2, 1993. A comparative analysis was made with the following changes and additions. There were considered tendencies of legislative support of notarial activity in the transition period from the total state administration, gaining the independence of Ukraine to the standards of the European (Latin) notary in the state.

The normative legal act was analyzed, from the point of view of further development, modernization of the system of bodies and officials who perform notarial acts; for the field of law; for the field of legislation, for science, the educational process, in particular.

6. Положення про порядок реєстрації приватної нотаріальної діяльності: наказ Міністра юстиції України від 4.03.1994. URL: https:// https://zakon.rada.gov.ua/laws/ show/z0041-94. Наказ втратив чинність на підставі Наказу Міністерства юстиий.№ 2151/5 від 12.12.2008 року; Положення про порядок реєстрації приватної нотаріальної діяльності та заміщення приватного нотаріуса: наказ Міністра юстиції України від 22.03.2011. № 871/5. URL: https://zakon. rada.gov.ua/laws/show/z0388.

7. Про внесення змін до деяких законодавчих актів України щодо забезпечення ефективності інституційного механізму запобігання корупції: Закон України від 02.10.2019. База даних «Законодавство України». Верховна Рада України. URL: https://zakon.rada.gov.ua/laws/show/14020; Про внесення змін до Закону України «Про нотаріат» щодо усунення законодавчих колізій та прогалин: Закон України від 14 липня 2020. База даних «Законодавство України». Верховна Рада України. URL: https://zakon.rada.gov.ua/laws/show/77520\#n33. 


\title{
УДОСКОНАЛЕННЯ ПРАВОВОГО РЕГУЛЮВАННЯ ТРАНСПЛАНТОЛОГІї У СВІТЛІ СВРОПЕЙСЬКИХ СТАНДАРТІВ
}

\begin{abstract}
БОГОМАЗОВА Ірина Олександрівна - кандидат юридичних наук, доцент кафедри медичного права, факультет післядипломної освіти Львівського національного медичного університету імені Данила Галицького
\end{abstract}

УДК 340.12:342.7

DOI 10.32782/LAW.2020.3.25

В статье обсуждается возможность введения презумпиии согласия на издятие анатомических материалов после смерти человека. Поддаются анализу альтернативнъе способъ построения правил по умолчанию для урегулирования такой процедурьл. Обзор практики ЕСПЧ дает основания утверждать, что введение презумпиии согласия не противоречит Конвениии, но требует обеспечения гарантий для иленов семей умерших возразить против проведения этой процедуры в отношении умершего. Введение презумпиии согласия позволит перераспределить удельный вес ответственности за проведение процедуры между государством, врачами и членами семьи умершего.

Ключевъге слова: трансплантация, донорство, анатомические материаль, фетальные материальл.

\section{Постановка проблеми}

Можливість трансплантації органів, тканин та клітин людини зазнає особливої уваги з боку українських правників. Зазначена тема концентрує моральне, правове, психологічне й соціальне напруження, оскільки процедура пов'язана з ймовірною смертю пацієнта у разі відсутності змоги замінити нежиттєздатний орган, смертю людини, тіло якої може послугувати трансплантологічним матеріалом; загроза втрати фізичного здоров'я живого донора.

Правова інституціоналізація трансплантології потребує не лише медико-наукового обгрунтування, а й етичного осмислення dcix переваг у «невтомній боротьбі людства за максимальне продовження життя» та «очевидних складнощів, спричинених цією боротьбою» $[1$, с. 81$]$.

Закон України «Про застосування трансплантації анатомічних матеріалів людині» (далі - Закон) визначає трансплантацію як «спеціальний метод лікування, що полягає в пересадці анатомічного матеріалу людини від донора реципієнту і спрямований на відновлення здоров'я людини» [2]. Трансплантація? як спеціальний метод лікування, забезпечує додержання в Україні прав людини та захист людської гідності при застосуванні трансплантації та здійсненні іншої, пов'язаної з нею діяльності. Як відзначає Н. Крилова, ця процедура проводиться з метою порятунку життя, відновлення здоров'я, покращення якості життя» [3, с. 56], з чого випливають деякі обмеження для самої процедури, аби та була засобом забезпечення права людини на медичну допомогу, а не предметом торгівлі.

Думки науковців щодо доцільності впровадження «презумпції згоди» різняться. Зокрема, О. Капитова, О. Романовська, Г. Романовський вказують, що, «систематизувавши всі «за» $\mathrm{i}$ «проти», презумпція згоди на посмертне вилучення органів для трансплантації наглядно демонструє численну перевагу перших над другими. Можна сказати, що єдиним аргументом противників презумпції виступає необхідність захисту гідності особи і дотримання прав пацієнта, який 6 потенційним донором. Аргументи ж на користь презумпції згоди більш різноманітні і багаточисельні - починаючи від суто організаційних 
проблем нестачі часу і закінчуючи завідомо невигідністю такого рішення для благої суспільної мети розвитку трансплантології» [4, с. 104].

Як зазначає I.Я. Сенюта у своєму аналізі трансплантаційного законодавства, говорити про його реформування ще зарано, адже Україна перебуває у непростих соціально-економічних умовах. Зокрема, спостерігається зростання кількості соціально незахищених верств населення, що може слугувати фактором для комерціалізації цієї сфери: «... [Т]іло людини та його частини не повинні бути джерелом отримання фінансової вигоди, що чітко передбачено у ст. 21 Конвенції про права людини і біомедицину. Побутує думка до того ж, що ментально й психологічно український народ не готовий до радикальних кроків. Має бути втілена поетапна зважена державна програма, яка спрямовуватиметься, зокрема, й на просвітництво, висвітлення позитивів цього методу лікування, що подекуди є єдиним способом врятування життя, зокрема дитини (ця проблема добре відома, зрозуміла лише людям, які зустрілись «обличчям» із хворобою, яку можна вилікувати саме завдяки трансплантації)» [5, с.7]. Авторка вважає, що зміни до трансплантаційного законодавства, зокрема, в аспекті трансформації презумпцій, $\epsilon$ передчасними й потребують додаткового обговорення, з чим доцільно погодитись.

Пропонований матеріал є продовженням саме такого обговорення і містить результати проведеного нами аналізу вітчизняного законодавства на предмет забезпечення прав людини при вилученні анатомічних матеріалів. Зокрема, буде продемонстровано, що з етичного боку немає необхідності отримувати чітко висловлену пряму згоду від майбутнього донора, або від членів його сім'ї чи близьких родичів. Презумпція згоди на вилучення анатомічного матеріалу, за впровадження якої вже багато років виступають медичні асоціації, громадські діячі та правники у сфері медичного права, не суперечить правам людини при правильній конфігурації прав і обов'язків учасників відповідного правовідношення.

\section{Умови трансплантації за національним законодавством}

Закон передбачає вичерпний перелік умов, за яких можливим є застосування тран- сплантації. Згідно зі ст. 13 Закону трансплантація застосовується виключно за наявності медичних показань і здійснюється відповідно до галузевих стандартів у сфері охорони здоров'я за згодою об'єктивно поінформованої дієздатної особи (реципієнта), за винятком випадків, передбачених цим же законом.

Наявність у пацієнта медичних показань для застосування трансплантації встановлює консиліум лікарів закладу охорони здоров'я, у якому пацієнт перебуває на лікуванні чи диспансерному обліку. Окрім того, Закон встановлює, що у разі якщо реципієнт не досяг 14-річного віку або визнаний в установленому законом порядку недієздатним, трансплантація застосовується за згодою об'єктивно поінформованих його батьків або інших законних представників. Стосовно реципієнтів віком від 14 років або визнаних в установленому законом порядку обмежено дієздатними трансплантація застосовується за згодою таких об'єктивно поінформованих осіб. Цей аспект процедури можна вважати традиційним, оскільки отримання відповідної згоди вимагає ст. 43 Закону України «Основи законодавства про охорону здоров'я»' .

Закон передбачає низку обмежень на донорство анатомічних матеріалів як при житті, так і після смерті людини, які, знову ж таки, пов'язані загалом із необхідністю забезпечити право на якісну медичну допомогу, з одного боку, та додатковими гарантіями для забезпечення прав людини вразливих груп ${ }^{2}$, 3 іншого. Принаймні частина 3 означених підстав зумовлена міркуваннями емпіричного досвіду, зокрема повідомляють про масові

\footnotetext{
1 Виняток 3 цього правила становлять випадки, коли реципієнт перебуває у невідкладному стані, що становить пряму та невідворотну загрозу його життю, медична допомога із застосуванням трансплантації надається без згоди реципієнта, його батьків або інших законних представників.

2 Зокрема, вилучення органів не застосовується до осіб, які утримуються у місцях відбування покарань та попереднього ув'язнення; $є$ іноземцями та особами без громадянства, які незаконно перебувають в Україні; страждають на тяжкі психічні розлади; мають захворювання, що можуть передатися реципієнту або зашкодити його здоров'ю, крім випадків наявності поінформованої згоди реципієнта; надали раніше орган або частину органа для трансплантації (крім гемопоетичних стовбурових клітин); є вагітними.
} 
вилучення анатомічних матеріалів у місцях позбавлення волі в КНР [6, с. 2542].

Прижиттєве донорство можливе у разі родинного або перехресного донорства та лише за наявності добровільної та усвідомленої згоди на донорство анатомічних матеріалів, наданої у письмовому вигляді. Згода на вилучення анатомічних матеріалів надається після надання особі лікарем об'єктивної та доступної інформації про можливість виникнення ускладнень для ії здоров'я, а також про іï права у зв'язку з донорством ${ }^{3}$

Важливість гарантії стосовно надання повної та об’єктивної інформації донору і реципієнту щодо трансплантації органу, тканини чи іншого анатомічного матеріалу підкреслює Декларація про трансплантацію людських органів, прийнята 39-ю Всесвітньою медичною асамблеєю в жовтні 1987 року, а саме: «обов’язковим є якомога повніше обговорення пропонованої процедури 3 донором i реципієнтом або їх довіреними родичами або юридичними представниками. Аікар повинен бути об'єктивним при обговоренні процедури, при інформуванні і про відомий ризик, і можливі небезпеки, при пропозиції можливих альтернативних процедур. Лікар не повинен підтримувати очікування, які не виправдані обставинами. Інтерес лікаря до поглиблення наукових знань повинен завжди бути вторинним по відношенню до головного обов'язку лікаря перед пацієнтом. Завжди має бути отримано добровільну інформовану згоду» [7].

\section{Презумпція згоди вилучення фетальних матеріалів: національне законодавство і практика}

Свропейського суду з прав дюдини

Презумпція як юридична конструкція використовується для розподілу прав і обов'язків учасників суспільних відносин за невизначеності юридичного факту, замінюючи останній собою.

Практика низки країн передбачає, що кожна особа, котра не залишила прижиттєвої

\footnotetext{
3 у разі, якщо донором стовбурових клітин є особа віком до 18 років, інформація про можливість виникнення ускладнень для іiї здоров'я, а також про її права у зв'язку з донорством також надається батькам цієї особи або ії іншим законним представникам.
}

письмової незгоди на використання органів їі тіла для трансплантації, після іï смерті може бути використана як донор для тих, хто цього потребує. Такий спосіб вирішення характерний для Франції, Австрії, Бельгії, Іспанії, Греції, Португалії тощо. Слабша форма цієї презумпції передбачає, що кожна дієздатна особа, котра досягла 18-річного віку, має право написати інформативну згоду стати донором органів, тканин чи анатомічного матеріалу після їі смерті. Така практика поширена в СІІА, Японії, Німеччині, Великобританії тощо. де, як правило, фіксація такої згоди вже міститься в медичній картці пацієнта.

Так само, згідно із частиною 1 статті 16 Закону, кожна повнолітня дієздатна особа має право надати письмову згоду або незгоду на вилучення анатомічних матеріалів 3 іï тіла для трансплантації та/або виготовлення біоімплантатів після визначення ії стану як незворотна смерть (смерть мозку або біологічна смерть) відповідно до закону (далі - згода або незгода на посмертне донорство). Відомості щодо наданих особою письмової згоди або незгоди на посмертне донорство, письмової заяви про відкликання наданої раніше такої згоди або незгоди вносяться в установленому порядку до Єдиної державної інформаційної системи трансплантації органів та тканин в установленому порядку до Єдиної державної інформаційної системи трансплантації органів та тканин.

Таким чином, законодавцем закріплено презумпцію незгоди з вилученням анатомічних матеріалів в донора-трупа. Це, певна річ, найбезпечніша i найобережніша позиція 3 точки зору відповідальності закладів охорони здоров'я (та опосередковано держави у випадку відсутності адекватного реагування на порушення прав людини в цій сфері), і в цьому ж, як видається, полягає вразливість такого ставлення законодавця до проблем трансплантології, адже первинною метою проведення процедури є людина та ії життя і здоров'я.

Втім, здається, законодавця тут можна зрозуміти, адже є повчальний досвід держав, які запровадили презумпцію згоди на фетальну трансплантацію і наразилися на скарги 3 боку членів сім’ї громадян, анатомічні матеріали в яких було вилучені без їхньої згоди. 
Так, згідно із законодавством Латвії 2004 р., будь-яка дієздатна особа мала право, в письмовому вигляді, дати згоду або висловити відмову на використання свого тіла після смерті $[8$, 9] - аналогічно як в Україні, і таке волевиявлення мало обов'язкову юридичну силу. Крім того, особа, яка бажала скористатися вищезазначеним правом, зобов'язана була звернутися до компетентних органів держави, відповідно до процедури, встановленої урядом, 3 тим, щоб зафіксувати своє волевиявлення в спеціальному реєстрі. За відсутності явно вираженої волі померлого анатомічні матеріали могли бути використані, якщо ніхто 3 найближчих родичів (дітей, батьків, братів або сестер, дружина) не заперечував проти такого використання. Посмертне донорство органів і тканин з метою трансплантації було можливим тільки в разі відсутності заперечень $з$ боку донора, виражених за життя, або при відсутності заперечень 3 боку його найближчих родичів.

У справах Петрова проти Латвії та Ельберте проти Аатвії ЄСП А мав оцінити на відповідність Євроконвенції процедури вилучення анатомічних матеріалів у померлих членів сім'ї заявників [8, 9]. В обидвох випадках сім'ї померлих не були повідомлені про те, що лікарня вилучила анатомічні матеріали в їхніх загиблих родичів, а дізналися про це згодом в ході проведення розслідування у кримінальних справах. Згідно 3 позицією ЄСПл, такі дії лікувального закладу спричинили порушення права заявників на повагу до їхнього сімейного життя, що гарантоване ст. 8 Конвенції. Це відбулося, зокрема, через вади законодавства, а саме через те, що праву заявників бути поінформованими про намір вилучити анатомічні матеріали не відповідав обов'язок посадових осіб здійснити таке інформування. Абстрактне право бути поінформованим у зв'язку з абстрактним обов'язком поінформувати неодмінно суперечитиме розумінню прав людини Страсбурзьким судом як ефективних, а не теоретичних та ілюзорних [10].

Отже, згідно з практикою ЕСП $\lambda$ закріплення презумпції згоди на посмертну трансплантацію не становить порушення права людини близьких родичів на повагу до їх сімейного життя - випадку, якщо їм надана реальна можливість заборонити вилучати анатомічні матеріали члена їхньої сім’ї після смерті.

\section{Висновки}

При розгляді можливості запровадження презумпції згоди в Закон України «Про застосування трансплантації анатомічних матеріалів людині» вважаємо за потрібне врахувати не лише ту обставину, що презумпція згоди може зумовити суспільний резонанс, що є супутником будь-яких змін як позитивних, так і негативних. Широкому загалу важливо зрозуміти, що конструкція презумпції згоди існує не тільки для забезпечення потреб людини, але і для розподілу відповідальності між учасниками правовідношення щодо вилучення та трансплантації анатомічних матеріалів. При цьому, члени сім'ї померлої людини в більшості випадків не заперечують проти вилучення, однак не згодні брати на себе всю повноту відповідальності. Відтак, правовідношення із вилучення анатомічних матеріалів повинно бути побудоване на засадах справедливого розподілу відповідальності між безпосередніми учасниками правовідношення та державою.

\section{Аітература}

1. Аболіна Т.Г., Нападиста В.Г., Рихліцька О. Д. та ін. Прикладна етика. Навчальний посібник / За наук. ред. Панченко В.I. К.: «Центр учбової літератури», 2012, 392 с.

2. Закон України «Про застосування трансплантації анатомічних матеріалів людині» // Відомості Верховної Ради (ВВР), 2018, № 28, ст.232

3. Крылова Н. Е. Уголовное право и биоэтика (уголовно-правовые проблемы применения современных биомедицинских технологий): дисс. ... д-ра юрид. наук: 12.00.08.. Москва, 2006. - 411 с.

4. Капитова Е.А. Правовое регулирование трансплантологии. Монография /Е.А. Капитова, О.В. Романовская, Г.Б. Романовский Г.Б.. - Москва: ООО «Проспект», 2016,144 c.

5. Сенюта І.Я. Трансформація презумпції незгоди у презумпцію згоди: ризики і переваги // Український медичний часопис, 2012, c. $7,8$. 


\section{АНОТАЦІЯ}

У статті обговорюється можливість запровадження презумпчї згоди на вилучення анатомічних матеріалів після смерті людини. Піддаються аналізу альтернативні способи побудови правил за замовчуванням для врегулювання такої процедури. Огляд практики ЕСПЛ дає підстави стверджувати, що запровадження презумпиіӥ згоди не суперечить Конвениї, але потребує забезпечення гарантій для членів сімей померлих заперечити проти проведення иієї процедури щодо померлого. Запровадження презумпиї згоди дозволить перерозподілити питому вагу відповідальності за проведення процедури між державою, лікарями та членами сім'ї померлої особи.

Ключові слова: трансплантачія, донорство, анатомічні матеріали, бетальні матеріали.

6. Vasilenko M.D. Presumption of Consent in the ECHR Practice and Legal Systems: legal models for organ removal for transplantation / Mykola D Vasilenko, Anastasiia O Zaporozhchenko, Borys A Perezhniak // Wiad Lek. 2019;72(12 cz 2), Pp. 2541-2546/

7. Декларація стосовно трансплантації людських органів, прийнята 39-ю Всесвітньою медичною асамблеєю 30.10 .1987 р. : [URL: https://zakon.rada.gov.ua/laws/ show/995_330\#Text]

8. Judgement of 24 June 2014 in the case of Petrova v. Latvia http://hudoc.echr.coe.int/ eng? $\mathrm{i}=001-144997]$

9. Judgement of 13 January 2015 in the case of Elberte v. Latvia : [URL: http://hudoc. echr.coe.int/rus?i=001-150234]

10. Judgement of 28 May 2002 in the case of Stafford v. the United Kingdom : [URL: http:// hudoc.echr.coe.int/eng?i=001-60486]

\section{ON IMPROVEMENT OF THE LEGAL REGULATION OF TRANSPLANTOLOGY IN UKRAINE ACCORDING TO THE EUROPEAN STANDARDS}

The article discusses the possibility of introducing the presumption of consent to the removal of anatomical materials after death. Under the legislation of a number of countries any person who has not given his or her lifelong written consent to the use of his or her organs for transplantation may, after his or her death, be used as a donor for those in need. This solution is typical for France, Austria, Belgium, Spain, Greece, Portugal, etc. The weaker form of this presumption is that every able-bodied person who has reached the age of 18 has the right to write an informative consent to become a donor of organs, tissues or anatomical material after his death. This practice is widespread in the United States, Japan, Germany, Great Britain, etc. where, as a rule, the fixation of such consent is already contained in the patient's medical card.

According to ECtHR practice, enshrining the presumption of consent to a post-mortem transplant does not constitute a violation of the human right of close relatives to respect for their family life, provided that they have a real opportunity to prohibit the removal of their family members' anatomical materials after death.

Under the Ukrainian legislation, the disagreement with the removal of anatomical materials from the donor corpse is presumed. This is, of course, the safest and, perhaps, most cautious position in terms of the responsibility of health care facilities (and, indirectly, of the state in the absence of an adequate response to human rights violations in this area), and this seems to be the vulnerability of the legislator's attitude to problems of transplantation, because the primary purpose of the procedure is a person and his life and health.

Alternative ways of constructing default rules to handle such a procedure are analyzed. The review of the case law of the ECtHR enables to suggest that the adoption of the consent default rule is not contrary to the Convention but requires the provision of guarantees for family members of the deceased to object to this procedure in relation to the deceased. The introduction of the presumption of consent will redistribute the share of responsibility for the procedure between the state, doctors and family members of the deceased.

Key words: transplantation, donation, anatomical materials, fetal materials. 


\title{
КЛАСИФІКАЦІЯ ГАРАНТІЙ ПРАВ ГРОМАДЯН, ЗАСУДЖЕНИХ ДО ПОЗБАВЛЕННЯ ВОЛІ В УКРАЇНІ
}

\author{
ПОЧАНСЬКА Олена Сергї̈вна - доктор юридичних наук, доцент кафедри \\ правового забезпечення господарської діяльності факультету № 6 Харківського \\ національного університету внутрішніх справ \\ ORCID: https://orcid.org/0000-0003-3953-8660 \\ УДК 342.9 \\ DOI 10.32782/LAW.2020.3.26
}

\section{Постановка проблеми}

Поряд із завданням визнання та закріплення прав і свобод громадян, засуджених до позбавлення волі, важливою проблемою 6 їх реальна реалізація, яка потребує належного забезпечення з боку держави за допомогою відповідних адміністративно-правових засобів, які надають усім правам і свободам засудженої особи реального змісту. При цьому наявність низки засобів матеріального і процесуального характеру сама пособі ще не є запорукою якісного забезпечення прав і свобод громадян, засуджених до позбавлення волі в Україні. Їх ефективна реалізація, охорона та захист значною мірою залежать від системи організаційно-правових (інституційних) гарантій, спрямованих на забезпечення прав і свобод засуджених громадян, а також належне виконання відповідних обов'язків органами державної влади та місцевого самоврядування, їх службовими і посадовими особами, на боротьбу 3 правопорушеннями у даній сфері, утвердження загального режиму законності.

Аналіз останніх досліджень і публікацій

Загальнотеоретичні питання змісту та захисту прав людини розглядалися в працях таких вітчизняних і зарубіжних учених, як В. Авер'янов, Ю. Битяк, ᄉ. Глухарьова, О. Аукашева, М. Матузов,
О. Музичука, П. Рабінович, О. Скакун, Ю. Тодика та ін. Права i свободи засуджених, їх дотримання при виконанні кримінального покарання були предметом наукового аналізу С. Бараша, О. Джужи, В. Льовочкіна, О. Лисодіда, Н. Рябих, О. Северин, А. Степанюка, I. Яковець. Окремі аспекти функціонування механізму забезпечення прав засуджених громадян досліджували I. Бородін, М. Гаврильців, T. Заворотченко, I. Ієрусалімова, В. Кравчук, О. Соколенко та ін.

Не вирішені раніше проблеми

Проте, незважаючи на численні праці у цій сфері, дослідженню питання організаційно-правових гарантій прав громадян, засуджених до позбавлення волі, не приділяється достатньої уваги, що й зумовлює актуальність даної статті.

\section{Мета та завдання статті}

Метою статті є дослідження змісту i особливостей організаційно-правових гарантій прав і свобод громадян, засуджених до позбавлення волі в Україні, що передбачає уточнення поняття «юридичні гарантії», загальну характеристику організаційно-правових (інституційних) гарантій, визначення основних видів та аналіз змісту організаційно-правових гарантій прав та свобод громадян, засуджених до позбавлення волі в Україні. 
Наукова новизна дослідження полягає у тому, що стаття є першою науковою працею, у якій запропоновано класифікацію організаційно-правових гарантій прав громадян, засуджених до позбавлення волі.

\section{Виклад основного матеріалу}

У найзагальнішому розумінні гарантії є системою засобів, що сприяють реалізації прав і свобод, охоплюваних законом інтересів та обов'язків [1, с.160]. Довідкова література визначає юридичні гарантії як встановлені законом засоби безпосереднього забезпечення, використання, додержання, виконання і правильного застосування норм права [2, с.123]. Як засоби, умови, способи, що забезпечують здійснення у повному обсязі й всебічну охорону прав і свобод особи, це поняття охоплює собою всю сукупність об'єктивних і суб'єктивних чинників, спрямованих на практичну реалізацію прав і свобод, на усунення можливих перешкод їх здійснення [3, с.555].

у загальній теорії права правові гарантії класифікують за низкою критеріїв. Проте найбільш обгрунтованим є розподіл усіх юридичних гарантій прав і свобод людини і громадянина відповідно до їх форми на нормативно-правові та організаційно-правові [4, с.8]. Нормативно-правові гарантії прав являють собою сукупність правових норм, за допомогою яких забезпечуються реалізація, порядок охорони і захисту прав та свобод особистості. До нормативно-правових гарантій відносять норми-принципи, юридичну відповідальність та юридичні обов'язки суб'єктів забезпечення прав і свобод громадян, передбачені законодавством. Організаційно-правові гарантії конституційних прав та свобод людини і громадянина - це різноманітна виконавчо-розпорядча, процедурна, контрольна та інша діяльність органів держави, місцевого самоврядування, посадових осіб, громадських організацій у сфері правотворчості та правозастосування, спрямована на створення сприятливих умов для користування громадянами своїми правами і свободами.
У юридичній науці організаційні гарантії визначаються як певний механізм організації та здійснення юридичного забезпечення реалізації, охорони і захисту прав і свобод людини та громадянина [5, c.60], створення сприятливих умов для реального користування громадянами своїми правами і свободами [6, с.40], система заходів процедурного, режимного, контрольного та іншого характеру, зміст якої складають визначення, прийняття та вирішення державою завдань соціального і правового забезпечення діяльності, державний і громадський контроль, обробка інформації, організаційні процедури застосування заходів і зв'язку та ін. [7, c.282].

Усі організаційно-правові гарантії прав і свобод людини та громадянина можуть бути класифіковані за різними підставами. Насамперед, слід зазначити, що інституційна складова загального механізму забезпечення прав і свобод безпосередньо випливає з нормативної складової і містить у собі діяльність органів державної влади та місцевого самоврядування, політичних партій і громадських організацій, окремих громадян, що спрямована на реалізацію, охорону та захист прав і свобод людини та громадянина. Тож усі організаційно-правові гарантії прав і свобод можна поділити на ті, які пов'язані 3 функцією їх захисту від імені держави (перш за все, повсякденна робота уповноважених органів виконавчої влади, спрямована на охорону прав і свобод людини і громадянина), та ті, що пов'язані із здійсненням забезпечення прав і свобод людини та громадянина інститутами громадянського суспільства (серед яких слід окремо відзначити діяльність таких інституцій, які створені спеціально з цією метою (адвокатура), такі, для яких дана діяльність є основною (профспілки), та інші (засоби масової інформації, партії, добровільні об'єднання тощо). Відповідно ж до свого змісту, всі організаційно-правові гарантії прав і свобод людини та громадянина найчастіше розподіляють на контрольні, процедурні та організаційно-технічні [7, с.283]. 
Головною складовою адміністративно-правових гарантій прав та свобод людини і громадянина виступає контроль. Так, I. Бородін слушно підкреслює, що саме контроль, як основна гарантія прав та свобод громадян, знаходить свій прояв у своєму соціальному призначенні і поєднуе в собі елементи правоохоронної, правозастосовчої та управлінської діяльності:

а) правоохоронна діяльність спрямована на припинення протиправних дій посадових осіб і притягнення їх до юридичної відповідальності та передбачає вплив на порушників законодавства;

б) правозастосовча діяльність передбачає кваліфікований нагляд за тим, щоб реальна, фактична діяльність державних органів, їх посадових осіб відповідала тому, що встановлено законом, максимально забезпечувала права та свободи громадян;

в) управлінська сутність контрольної діяльності виявляється в правових актах контрольних органів, службових документах $[8$, с.24].

Аналіз чинного законодавства України, що регулює правовий статус осіб, засуджених до позбавлення волі, а також суб'єктів забезпечення їх прав, свобод та законних інтересів, дає змогу виділити наступні види контролю і нагляду у цьому напрямку діяльності:

1) Парламентський контроль. Верховна Рада України здійснює безпосередньо і через створювані нею органи контроль за дотриманням законності в діяльності органів і установ виконання покарань. Відповідно до Закону України «Про Уповноваженого Верховної Ради 3 прав людини», парламентський контроль за додержанням конституційних прав і свобод засуджених та захист їх прав на території України здійснюе Уповноважений Верховної Ради України з прав людини. Метою парламентського контролю за додержанням прав і свобод людини і громадянина 6 :

захист прав і свобод людини та громадянина, проголошених Конституцією України, законами України та міжнародними договорами України; запобігання порушенням прав i свобод людини та громадянина або сприяння їх поновленню;

- сприяння приведенню законодавства України про права і свободи людини та громадянина у відповідність з Конституцією України, міжнародними стандартами у цій галузі;

запобігання будь-яким формам дискримінації щодо реалізації людиною своїх прав і свобод;

сприяння правовій інформованості населення та захист конфіденційної інформації про особу та ін. [9, ст.3].

2) Урядовий контроль. Кабінет Міністрів України, як вищий орган у системі органів виконавчої влади, забезпечує виконання Конституції та законів України, актів Президента України, зокрема, щодо забезпечення прав та свобод людини і громадянина [10, ч.1,2 ст.116]. Відповідно до Закону України «Про Кабінет Міністрів України», Кабінет Міністрів України здійснюе постійний контроль за виконанням органами виконавчої влади Конституції України та інших актів законодавства України, вживає заходів щодо усунення недоліків у роботі зазначених органів [11, ст. 19].

3) Судовий контроль. Серед важливих завдань судової гілки влади в Україні, визначених Національною стратегією у сфері прав людини, слід відзначити такі, як забезпечення періодичних перевірок судом законності затримання, позбавлення свободи осіб, а також посилення ефективності судового контролю за підставами позбавлення свободи та ін. [12]. Здійснення у порядку, передбаченому Кримінальним процесуальним кодексом та Законом України «Про судоустрій і статус суддів», судового контролю за дотриманням прав, свобод та інтересів осіб у кримінальному провадженні, покладається на слідчих суддів - суддів суду першої інстанції, а у випадку, передбаченому ст.247 Кримінального процесуального кодексу, - на голів чи інших суддей Апеляційного суду Автономної Республіки Крим, апеляційного суду області, міст Києва та Севасто- 


\section{Цивільне, підприсмницьке, господарське та трудове право}

поля [13, ст.3, 247].

4) Прокурорський нагляд за виконанням кримінальних покарань. Відповідно до Закону України «Про прокуратуру», прокурор здійснює нагляд за додержанням законів в органах і установах виконання покарань при виконанні судових рішень у кримінальних справах, а також при застосуванні інших заходів примусового характеру, пов'язаних з обмеженням особистої свободи громадян [14, ст.22]. До основних напрямків діяльності органів прокуратури віднесено забезпечення нагляду за додержанням:

прав і свобод людини, загальних інтересів суспільства і держави при виконанні покарань та інших заходів примусового характеру, пов'язаних 3 обмеженням особистої свободи, відповідно до законів України, міжнародних договорів, згода на обов'язковість яких надана Верховною Радою України;

законодавства щодо запобігання катуванням чи нелюдському або такому, що принижує гідність, поводженню із засудженими;

- визначених законодавством вимог режиму, порядку та умов відбування покарань засудженими особами та ін. [15, п.2].

5) Відомчий контроль. Згідно зі ст.23 Кримінально-виконавчого кодексу України, за діяльністю органів і установ виконання покарань здійснюеться відомчий контроль вищестоящими органами управління і посадовими особами центрального органу виконавчої влади, що реалізує державну політику у сфері виконання кримінальних покарань [14]. Як головний орган у системі центральних органів виконавчої влади, що здійснює державну політику у сфері виконання кримінальних покарань, Міністерство юстиції України забезпечує контроль за дотриманням прав людини і громадянина, вимог законодавства щодо виконання і відбування кримінальних покарань, реалізацією законних прав та інтересів засуджених осіб [16]. Також Міністерством юстиції України спрямовується і координується діяльність Державної кримінально-виконавчої служби України, до завдань якої відноситься організація контролю за дотриманням прав людини і громадянина, вимог законодавства щодо виконання і відбування кримінальних покарань, реалізація законних прав та інтересів засуджених осіб.

6) Оперативно-розшуковий контроль. Відповідно до Закону України «Про оперативно-розшукову діяльність», оперативними підрозділами органів і установ виконання покарань у колоніях здійснюється оперативно-розшукова діяльність, основним завданням якої 6 пошук і фіксація фактичних даних про протиправну діяльність окремих осіб та груп з метою: забезпечення безпеки засуджених, персоналу колоній та інших осіб; попередження і виявлення злочинів, вчинених у колоніях, а також порушень встановленого порядку відбування покарання; вивчення причин і умов, що сприяють вчиненню злочинів та інших правопорушень; надання правоохоронним органам, які здійснюють оперативно-розшукову діяльність або кримінальне провадження, допомоги в розкритті, припиненні та попередженні злочинів [14, ст.104].

7) Контроль, який здійснюється шляхом та під час відвідування установ виконання покарань. Відповідно до норм кримінально-виконавчого законодавства, право на відвідування установ виконання покарань для здійснення контролю та проведення перевірок мають:

- Президент України або спеціально уповноважені ним представники;

- Прем'єр-міністр України або спеціально уповноважені ним представники;

- Уповноважений Верховної Ради України з прав людини або спеціально уповноважені ним представники;

голова, заступники голови та члени Комісії при Президентові України у питаннях помилування;

Міністр юстиції України або спеціально уповноважені ним представники;

Міністр внутрішніх справ України, Голова Національної поліції або спеціально уповноважені ними представники; 
- члени Европейського комітету 3 питань запобігання катуванням чи нелюдському або такому, що принижує гідність, поводженню чи покаранню;

Голова Ради міністрів Автономної Республіки Крим, голови місцевих державних адміністрацій, на території яких вони розташовані, або спеціально уповноважені ними представники;

народні депутати України, їх помічники-консультанти, депутати Верховної Ради Автономної Республіки Крим та депутати місцевих рад;

Генеральний прокурор, а також уповноважені ним прокурори і прокурори, які здійснюють на відповідній території нагляд за додержанням законів при виконанні судових рішень у кримінальних справах, а також при застосуванні інших заходів примусового характеру, пов'язаних 3 обмеженням особистої свободи громадян;

голова, заступник голови та члени спостережної комісії, які здійснюють організацію громадського контролю за дотриманням прав і законних інтересів засуджених під час виконання кримінальних покарань;

сільський, селищний, міський голова або спеціально уповноважені ними представники - на території відповідної місцевої ради;

члени громадських рад при центральному органі виконавчої влади, що реалізує державну політику у сфері виконання кримінальних покарань, та його територіальних підрозділах - на відповідній території [14, ч.1 ст.24].

Представники громадських організацій, експерти, учені та фахівці, залучені Уповноваженим Верховної Ради України 3 прав людини на договірних засадах до виконання функцій національного превентивного механізму, відвідують установи виконання покарань на підставі окремого письмового доручення Уповноваженого [14, п.7 ч. 1 ст.24].

8) Громадський контроль за дотриманням прав засуджених під час виконання кримінальних покарань. Громадський контроль за дотриманням прав засуджених під час виконання кримінальних покарань здійснюють спостережні комісії, які діють на підставі Кримінально-виконавчого кодексу та Положення про спостережні комісії. У випадках, встановлених законодавством України, громадський контроль за дотриманням прав засуджених під час виконання кримінальних покарань можуть здійснювати громадські об'єднання. Об'єднання громадян та засоби масової інформації, неурядові правозахисні організації, релігійні та благодійні організації, окремі особи в порядку, встановленому цим Кодексом і законами України, можуть надавати допомогу органам та установам виконання покарань у виправленні засуджених і проведенні соціально-виховної роботи [14, ст.25]. Зокрема, предметом контролю правозахисних організацій 6 поточна державна політика в галузі прав людини, рішення, дії державних органів та їх посадових осіб, внаслідок яких порушуються права людини і основоположні свободи, або створюються перешкоди для здійснення цих прав і свобод.

9) Міжнародний контроль. Як відзначають експерти, міжнародний контроль 6 «важливим і необхідним у сфері виконання кримінальних покарань і забезпеченні прав осіб, які утримуються в місцях фактичного обмеження або позбавлення волі та засуджених» $[17$, с.50]. Міжнародний контроль за дотриманням прав засуджених та діяльністю кримінально-виконавчих установ здійснюється міжнародними організаціями на підставі сучасних міжнародних документів у галузі прав людини, що є невід'ємною складовою національної системи правового забезпечення прав громадян, засуджених до позбавлення волі в Україні. До найбільш впливових міжнародних організацій у цій сфері належать Комітет ООН проти катувань та Европейський Комітет із запобігання катуванням та поганому поводженню. Так, зокрема, відповідно до норм Европейської конвенції запобігання катуванням чи нелюдському або такому, що принижує гідність, поводженню чи покаранню [18, ст.2], члени 


\section{Цивільне, підприсмницьке, господарське та трудове право}

цих організацій мають право відвідувати будь-які місця, де утримуються особи, позбавлені волі 3 метою дослідження умов тримання, вивчення фактів, що можуть свідчити про застосування тортур до осіб, та інформування широкої громадськості і органів державної влади про стан дотримання прав людини, а також про виявлені факти катувань.

Важливе місце у діяльності органів виконавчої влади по забезпеченню прав та свобод людини і громадянина займають адміністративні процедури (зокрема, процедури участі відповідних суб'єктів у тих чи інших заходах щодо: ресоціалізації засуджених осіб, укладання угод (договорів) про співпрацю, надання юридичних, психологічних, реабілітаційних та інших послуг засудженим особам, реалізації соціально-реабілітаційних програм та профілактичних заходів щодо запобігання вчинення злочинів тощо). 3 одного боку, такі процедури сприяють загальному підвищенню ефективності управлінської діяльності, а 3 іншого, - забезпечують необхідну послідовність у реалізації громадянами своїх прав і свобод. Раціонально побудовані та детально визначені у законодавстві процедури діяльності державних органів становлять собою ефективну гарантію забезпечення прав і свобод громадян, є необхідною складовою механізму їх захисту від зловживання владними повноваженнями й некомпетентності у діяльності службових і посадових осіб органів державної влади та органів місцевого самоврядування.

До системи організаційно-правових гарантій прав і свобод людини і громадянина також слід віднести й такі засоби, як моніторингова діяльність та соціально-психологічна й профілактична діяльність державних і недержавних суб'єктів, спрямована на подолання психологічної деформації засуджених, їх соціальну адаптацію, відновлення соціального статусу та реінтеграцію у суспільство шляхом підвищення суспільно-політичної свідомості засуджених громадян (зокрема, формування в них свідомого ставлення до викорис- тання прав і свобод, а також виконання обов’язків), підвищення рівня правової культури, здобуття освіти, формування необхідних умінь і навичок, що допоможуть успішно реінтегруватися у суспільство.

\section{Висновки}

Отже, основною організаційно-правовою гарантією додержання, реалізації та захисту прав і свобод громадян, засуджених до позбавлення волі, є державний контроль. Проте все більшого значення у сучасних умовах демократизації публічних відносин та децентралізації державної влади набуває й громадський контроль за додержанням та реалізацією прав і свобод громадян, засуджених до позбавлення волі в Україні. Нарешті, ще одним невід'ємним елементом загальної системи гарантій прав і свобод громадян, засуджених до позбавлення волі, 6 міжнародний контроль за дотриманням прав засуджених та діяльністю кримінальновиконавчих установ, що здійснюеться відповідними міжнародними організаціями на підставі норм сучасних міжнародних документів у галузі прав людини. До інших видів організаційно-правових гарантій прав і свобод громадян, засуджених до позбавлення волі, віднесено процедурні гарантії, що сприяють загальному підвищенню ефективності управлінської діяльності та забезпечують необхідну послідовність у реалізації засудженими своїх прав i свобод, а також моніторингову діяльність та різноманітну соціально-психологічну й профілактичну діяльність державних і недержавних суб'єктів забезпечення прав i свобод громадян, засуджених до позбавлення волі в Україні.

\section{Лiтература}

1. Виконавча влада і адміністративне право / за заг. ред. В. Б. Авер'янова. - К. : Ін-Юре, 2002. - 668 c.

2. Головченко В. В. Юридична термінологія : довідник / В. В. Головченко, В. С. Ковальський. - К. : Юрінком Інтер, 1998. - 219 c. 
3. Аисенков С. $\lambda$. Гарантії прав та свобод людини i громадянина /С. А. Аисенков, А. П. Таранов // Юридична енциклопедія: В 6 т. / редкол.: Ю. С. Шемшученко (відп. ред.) та ін. - Т. 1: А-Г. - К.: «Укр. енцикл.», 1998. - 672 с.

4. Пушкіна О. В. Конституційний механізм забезпечення прав людини i громадянина в Україні: проблеми теорії і практики: автореф. дис. на здобуття наук. ступеня докт. юрид. наук : спец.: 12.00.02 «Конституційне право» / О.В.Пушкіна; Нац. юрид. акад. України ім. Я. Мудрого. - X., 2008. - 48 c.

5. Рабінович П. М. Права людини і громадянина: навч. посіб. / П. М. Рабінович, М. І. Хавронюк. - К. : Атіка, 2004. - 464 с.

6. Гаврильців М. Т. Організаційноправові гарантії конституційного права ^юдини та громадянина. на судовий захист у сфері публічних правовідносин / М. Т. Гаврильців // Наук. вісник Міжнар. гуманіт. ун-ту: Серія: Юриспруденція. - 2016. - № 22. - С.38-41 [Електронний peсурс]. - Режим доступу: http://vestnikpravo.mgu.od.ua/archive/ juspradenc22/10. pdf.

7. Теория государства и права : курс лекций / под ред. Н. И. Матузова иА. В. Малько. - М. : Юристъ, 1999. - 672 с.

8. Бородін I. $\lambda$. Адміністративноправові способи захисту прав та свобод людини і громадянина : автореф. дис. на здобуття наук. ступеня доктора юрид. наук : спец. 12.00.07 «Адміністративне право i процес. Фінансове право. Інформаційне право» / I.ᄉ. Бородін ; Національний ун-т внутрішніх справ. Харків, 2004. - 37 с.

9. Про Уповноваженого Верховної Ради з прав людини : Закон України : від 23.12.1997 р., № 776/97-ВР // Відомості Верховної Ради України. - 1998. - № 20. - Ст.99.

10. Конституція України // Відомості Верховної Ради України. - 1996. - № 30. Cт. 141.

11. Про Кабінет Міністрів України : Закон України : від 27.02.2014 р., № 794VII // Відомості Верховної Ради. - 2014. № 13. - Ст.222.
12. Про затвердження Національної стратегіï у сфері прав людини : Указ Президента України : від 25.08.2015 р.,№ 501/2015 // Офіційний вісник Президента України. - 2015. - № 20. Cт.1203.

13. Кримінальний процесуальний кодекс України : Закон України : від 13.04.2012 р., № 4651-VI // Відомості Верховної Ради України. - 2013. - № 9-10, № 11-12, № 13. - Ст.88.

14. Кримінально-виконавчий кодекс України : Закон України : від 11.07.2003 р., № 1129-IV // Відомості Верховної Ради України. - 2004. - № 3-4. - Ст. 21.

15. Про організацію діяльності прокурорів 3 нагляду за додержанням законів при виконанні судових рішень у кримінальних справах, а також при застосуванні інших заходів примусового характеру, пов'язаних 3 обмеженням особистої свободи громадян : Наказ Генеральної прокуратури України : від 20.04.2016 р., № 161 [Електронний ресурс]. - Режим доступу: http://www. gp.gov.ua/ua/gl.html?_m=publications\&_ $\mathrm{t}=\mathrm{rec} \& \mathrm{id}=94102$.

16. Про затвердження Положення про Міністерство юстиції України : Постанова Кабінету Міністрів України : від 02.07.2014 p., № 228 // Офіційний вісник України. 2014. - № 54. - Ст. 1455.

17. Проблеми забезпечення прав засуджених у кримінально-виконавчій системі України. / В. А. Бадира, О. П. Букалов, А. П. Гель, М. В. Романов, I. С. Яковець; За заг. ред. Є. Ю. Захарова. Харківська правозахисна група. - Х. : Права людини, 2011. - 368 c.

18. Европейська

Конвенція про запобігання катуванням чи нелюдському або такому, що принижує гідність, поводженню чи покаранню : Міжнародний документ Ради Европи : від 26.11.1987 р. [Електронний ресурс]. Режим доступу: http://zakon2.rada.gov.ua/ laws/show/995_068. 


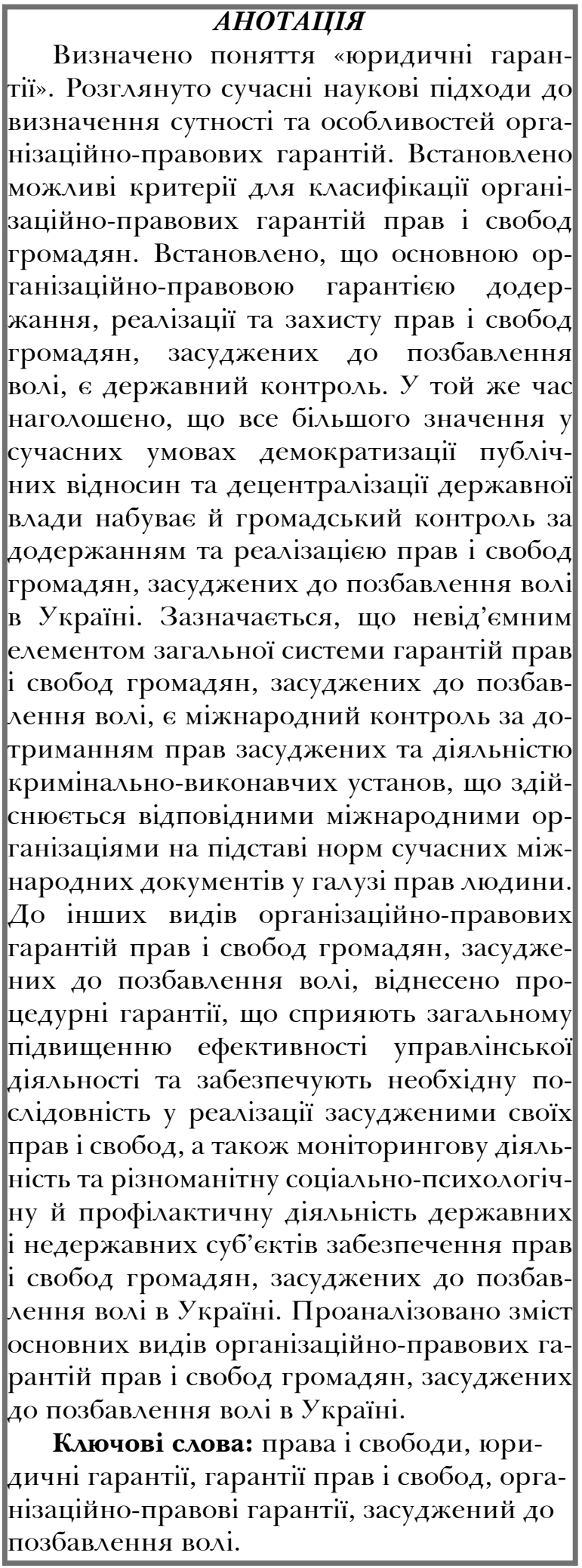

\section{SUMMARY}

The concept of "legal guarantees" is defined. Modern scientific approaches to determining the nature and features of organizational and legal guarantees are considered. Possible criteria for classification of organizational and legal guarantees of rights and freedoms of citizens are established. It is established that the main organizational and legal guarantee of observance, realization and protection of the rights and freedoms of citizens sentenced to imprisonment is state control. At the same time, it was emphasized that in the current conditions of democratization of public relations and decentralization of state power, public control over the observance and realization of the rights and freedoms of citizens sentenced to imprisonment in Ukraine is becoming increasingly important. It is noted that an integral part of the general system of guarantees of the rights and freedoms of citizens sentenced to imprisonment is international control over the rights of convicts and the activities of penitentiaries, carried out by relevant international organizations on the basis of modern international human rights instruments. Other types of organizational and legal guarantees of the rights and freedoms of citizens sentenced to imprisonment include procedural guarantees that contribute to the overall efficiency of administrative activities and ensure the necessary consistency in the implementation of convicts' rights and freedoms, as well as monitoring activities and various socio-psychological and preventive activity of state and non-state subjects of ensuring the rights and freedoms of citizens sentenced to imprisonment in Ukraine. The content of the main types of organizational and legal guarantees of the rights and freedoms of citizens sentenced to imprisonment in Ukraine is analyzed.

Key words: rights and freedoms, legal guarantees, guarantees of rights and freedoms, organizational and legal guarantees, sentenced to imprisonment. 


\title{
ПРАВОВА ОСНОВА НАДАННЯ ПУБЛІЧНИХ ПОСЛУГ СУБ'СКТАМИ ПУБЛІЧНОЇ АДМІНІСТРАЩІї ЩОДО ДЕРЖАВНОÏ РЕЕСТРАЦIÏ РЕЧОВИХ ПРАВ НА НЕРУХОМЕ МАЙНО
}

\author{
МАРТИНЮК Наталія Миколаївна - здобувач кафедри адміністративного \\ та митного права Університету митної справи та фінансів \\ УДК: 342.95 \\ https://orcid.org/0000-0001-7623-2260 \\ DOI 10.32782/LAW.2020.3.27
}

\begin{abstract}
Научная статья посвящена освещению правовой основе предоставления публичныхх услуг суббектами публичной администрации в сбере государственной регистрации прав на недвижимое имущество. Рассмотренъ законодательнъие и подзаконнъле актьл, регулирующие предоставление публичньх услуг в деятельности органов исполнительной власти и местного самоуправления и въделенъ нормативноправовые акть, регулирующие предоставление публичныхх услуг в сбере государственной регистрачии прав на недвижимое имущество.

Правовыле акть, регулирующие общественнвие отношения предоставления публичнъхх услуг суббектами публичной администрации в сбере государственной регистрации прав на недвижимое имущество, классибицированъ: юридической силой (законъ Украинъ, подзаконнъе нормативныле акть); объектом регулирования (те, которые регулируют поведение людей, определяюоих права и обязанности субъектов обращениях предоставления публичныхх услуг как участников административно-правовъхх отношений; $и$ те, которьие определяют правовой статус подразделений государственной регистрации прав на недвижимое имущество); предметом регулирования (недвижимое имущество (квартира, дома, гаражи и т.д.) консультационная помощь, справочная и инбормационная работа, обормление материалов по вопросам недвижимого имущества).

На основании анализа нормативно-правовъхх актов к основнъим пробелов в правовом регулировании предоставления публичныхх услуг субъектами публичной администрации в
\end{abstract}

сбере государственной регистрачии прав на недвижимое имущество в этом направлении отнесенъ: отсутствие конщепции предоставления публичных услуг подразделениями по государственной регистрации прав на недвижимое имущество; нормативная незакрепленность критериев оценки вббективности качества предоставления публичнъхх услуг деятельности субъектов публичной администрации; нарушение принципов предоставления публичньх услуг, коллизии в нормативно-правовом регулировании предоставления публичных услуг в сбере государственной регистрации прав на недвижимое имущество и т.д.

Ключевъе слова: собственность, государственная регистрация, государственная регистрачия прав на недвижимое имущество, нормативно-правовой акт, публичная услуга.

Постановка проблеми

Аюдина, їі права та свободи в Україні визнані головною соціальною цінністю, а головним завданням органів виконавчої влади є саме надання якісних публічних послуг громадянам, е тому числі у сфері державної реєстрації речових прав на нерухоме майно. Це випливає із сутності нової ролі держави у відносинах з людиною, закріпленою в Конституції України. Зокрема, ст. 3 Основного Закону проголошує «утвердження i забезпечення прав і свобод людини є головним обов'язком держави». Громадяни у відносинах із владою є не прохачами, а суб'єктами звернення послуг. До того ж держава в особі публічновладних органів орієнтується на потреби осо- 


\section{Цивільне, підприсмницьке, господарське та трудове право}

би, так само як у приватному секторі надавачі публічних послуг орієнтуються на потреби споживача, його запити та очікування [1].

У зв’язку з цим у науковій літературі починають звертати увагу на таку нову функцію виконавчої влади, як надання публічних послуг, оскільки ця функція становить найважливішу складову управлінської діяльності, походить від загального змісту державного управління, становить змістову характеристику діяльності тощо.

\section{Огляд останніх досліджень та публікацій}

Питання публічних послуг в Україні значною мірою потребують грунтовних наукових досліджень та відповідного адміністративно-правового оформлення. Безперечно, вони певною мірою були предметом науково-теоретичних досліджень таких вчених як В. Авер'янов, К. Афанасьєв, Б. Борисов, О. Вінніков, В. Гаращук, Н. Гнидюк, І. Голосніченко, Я. Гонцяж, В. Долечек, В. Евдокименко, І. Ібрагімова, Р. Калюжний, А. Каляєв, В. Кампо, С. Ківалов, А. Кірмач, В. Кудря, Т. Коломоєць, І. Коліушко, Р. Куйбіда, І. Лазарєв, А. Аастовецький, М. Аесечко, А. Аіпінцев, О. Аюхтергандт, Н. Нижник, О. Пастух, В. Петренко, М. Острах, О. Поляк, В. Тимощук, О. Харитонова, В. Ципук, А.Чемерис, Б. Шльоер, Х. Ярмакі та ін. [2, с. 155]. Однак питанням розгляду правової основи надання публічних послуг суб'єктами публічної адміністрації у сфері державної реєстрації речових прав на нерухоме майно майже не вивчалося.

Метою даної статті $\epsilon$ розгляд нормативно-правових актів надання публічних послуг суб'єктами публічної адміністрації у сфері 3 державної реєстрації речових прав на нерухоме майно.

\section{Виклад основного матеріалу}

Відповідно до ст. 3 Конституції України людина, іiі життя і здоров'я, честь і гідність, недоторканність і безпека визнаються в Україні найвищою соціальною цінністю. Права і свободи людини та їх гарантії визначають зміст і спрямованість діяльності держави. Держава відповідає перед людиною за свою діяльність.
Утвердження і забезпечення прав і свобод людини є головним обов'язком держави [3].

Серед міжнародних договорів, які регулюють окремі аспекти діяльності органів реєстрації прав, можна назвати: Гаазька конвенція від 05.10.1961р. [4]; Конвенція про захист прав людини і основних свобод від 04.11.1950 р. (ратифіковано Україною 17.07.1997 р.) [5]; Міжнародна конвенція про правову допомогу (країни СНД) 1993 р., яка набула чинності для України 14.04.1995 р. [6]. Відповідно до Наказу Мін'юсту «Про запровадження безпосередніх зносин органів юстиції України в рамках Конвенції про правову допомогу та правові відносини у цивільних, сімейних та кримінальних справах 1993 р. в частині виконання доручень у цивільних справах» від 02.08.2007 р. № 597/5, на виконання ст. 5 Конвенції в редакції Протоколу до неї, з 01.10.2007 р. було визначено органи, що уповноважені на здійснення безпосередніх зносин з відповідними уповноваженими органами Договірних Сторін Протоколу. Такими органами стали Головне управління юстиції Мінюсту, АРК, головні управління юстиції в областях, містах Києві та Севастополі [7]; Договір між Україною та Чеською республікою про правову допомогу і правові відносини у цивільних справах, набув чинності 18.11.2002 р.; Угода між Україною та Турецькою Республікою про правову допомогу та співробітництво у цивільних справах, набув чинності 02.05.2004 - ст. 27 закріплює, що до нерухомості й права власності на неї застосовується законодавство Договірної Сторони, на території якої знаходиться нерухоме майно. Аналогічні Договори підписані.

Україною із КНР (підписаний 31.10.1992 р., ратифікований 05.02.1993р.), Республікою Польща (ратифікований 04.02.1994 р.) Литовською Республікою (ратифікований 17.12.1993 р).

Повертаючись до національного законодавства, яке використовуються органами державної реєстрації прав у процесі виконання функцій і завдань держави, до першої групи можна зарахувати ті акти, норми яких, як правило, є матеріальними та регламентують загальні питання правового режиму об'єктів, 
які підлягають державній реєстрації - речові права та їх обтяження.

ЦК України від 16.01.2003 р. встановлює, що «до нерухомих речей (нерухоме майно, нерухомість) належать земельні ділянки, а також об'єкти, розташовані на земельній ділянці, переміщення яких є неможливим без їх знецінення та зміни їх призначення» (ст. 181 ЦК). Саме цей акт закріплює положення про те, що право власності та інші речові права на нерухомі речі, обтяження цих прав, їх виникнення, перехід і припинення підлягають державній реєстрації, яка є публічною, оскільки здійснюється відповідним органом влади(ст. 182 ЦК) [8]. Цей кодифікаційний акт також освітлюе широке коло питань матеріального права, які кожного дня використовуються в роботі державними реєстраторами, а саме: загальні положення про право власності, підстави його набуття і припинення, види такого права; розкриває основні питання спільної власності на майно, речові права на чуже майно; зобов'язальне право розкриває основний зміст та вимоги до правочинів на підставі яких може переходити право власності на об'єкти нерухомості та які підлягають державній реєстрації (договори купівлі-продажу, дарування, міни, оренди, іпотеки, договори довічного утримання та ін.); у книзі про спадкове право - зустрічаються норми, які регламентують порядок оформлення права на спадщину, предметом якої $\epsilon$ нерухоме майно, та визначають документи, на підставі яких указане право виникає.

Сімейний Кодекс України від 10.01.2002 p. [9] цікавиться інститутами права особистої приватної власності чоловіка та дружини та права спільно сумісної власності подружжя, якщо власність складається 3 нерухомого майна права, на які підлягають державній реєстрації.

ЗК України від 25.10.2001 р. [10] зазначає, що земля є основним національним багатством, що перебуває під особливою охороною держави».

Він закріплюе 3 форми власності на землю і передбачає можливість використання земельних ділянок на засадах спільної власності; допускає можливість набуття у приватну власність земельних ділянок фактично 3 усіх категорій земель; передбачає проведення розмежування земель державної і комунальної власності; визначає перелік земель, які не можуть передаватись у приватну власність; закріплює способи та механізм придбання громадянами та юридичними особами земельних ділянок у власність; встановлює перелік повноважень органів виконавчої влади та місцевого самоврядування у галузі земельних відносин.

Господарський кодекс України від 16.03.2003 р. [11] встановлюе правові основи господарської діяльності, яка базується на різноманітності суб’єктів господарювання різних форм власності.

Окрім Кодексів, до першої групи можна зарахувати інші акти законодавства, матеріальні норми яких можуть використовуватися у повсякденній діяльності Відділу: Закони України «Про нотаріат» [12]; «Про іпотеку» [13], який регулює основні питання, пов'язані 3 таким видом забезпечення виконання зобов'язання нерухомим майном, як іпотека (iз цього приводу необхідно зазначити, що іпотека відповідно до Закону № 1952-IV [14] чомусь розглядається як інше речове право, а не як вид обтяження (п.2 ч. 1 ст.1 Закону України «Про іпотеку»). Варто усунути протиріччя в указаних актах та привести норми Закону № 1952-IV у відповідність до Закону України «Про іпотеку»; «Про оренду землі» [15], де вирішуються такі питання як об'єкт, суб'єкт оренди та істотні умови договору оренди включаючи права та обов'язки сторін; «Про виконавче провадження» [16]; «Про господарські товариства» [17]; «Про відновлення платоспроможності боржника або визнання його банкрутом» [18] та ін.

Якщо розглядати правову основу порядку державної реєстрації речових прав на нерухоме майно, то відповідно до офіційної сторінки Державної реєстрації та нотаріату, то правою основою $\epsilon$ нормативно-правові акти, а саме: Закон України від 11 лютого 2010 року№ 1878-VI «Про державну реєстрацію речових прав на нерухоме майно та їх обмежень» та інших законодавчих актів України»; Закон України від 9 грудня 2011 року № 4152-VI «Про внесення змін до деяких законів України щодо забезпечення реалізації прав на нерухоме майно та їх обтяжень при їх державній реєстрації»; Закон України від 04.07.2012- 


\section{Цивільне, підприсмницьке, господарське та трудове право}

№ 5037-VI «Про внесення змін до деяких законодавчих актів України щодо вдосконалення та спрощення процедури державної реєстрації земельних ділянок та речових прав на нерухоме майно»; Постанова Кабінету Міністрів України від 17 жовтня 2013 року № 868 «Про затвердження Порядку державної реєстрації прав на нерухоме майно та їх обтяжень і Порядку надання інформації 3 Державного реєстру речових прав на нерухоме майно»; Порядок ведення Державного реєстру речових прав на нерухоме майно, затверджений постановою Кабінету Міністрів України від 26 жовтня 2011 року № 1141; Порядок надання інформації про зареєстровані земельні ділянки органу державної реєстрації прав та про зареєстровані речові права на земельні ділянки органу, що здійснює ведення Державного земельного кадастру, Порядок надання органом, що здійснює ведення Державного земельного кадастру, органу державної реєстрації прав доступу до перегляду кадастрових карт (планів), затверджені постановою Кабінету Міністрів України від 22 лютого 2012 року № 118; Постанова Кабінету Міністрів України від 21.11.2012 № 1204 «Про затвердження розміру і порядок використання плати за внесення змін до записів Державного реєстру речових прав на нерухоме майно та надання інформації із зазначеного реєстру»; Порядок доступу нотаріусів до Державного реєстру речових прав на нерухоме майно, затверджений наказом Міністерства юстиції від 02 серпня 2011 року № 1936а/5, зареєстрованим в Міністерстві юстиції 11 серпня 2011 року за № 963/19701; Зразок печатки державного реєстратора прав на нерухоме майно, Опис печатки державного реєстратора прав на нерухоме майно, затверджені наказом Miністерства юстиції від 22 листопада 2011 року № 3360/5, зареєстрованим в Міністерстві юстиції 22 листопада 2011 року за № 1332/20070; Порядок доступу банків до Державного реєстру речових прав на нерухоме майно, затверджений наказом Міністерства юстиції 24 листопада 2011 року № 3380/5, зареєстрованим в Міністерстві юстиції 24 листопада 2011 року за № 1340/20078; Порядок прийняття і розгляду заяв про внесення змін до запису та заяв про скасування запису Державного реєстру речових прав на нерухоме майно, за- тверджений наказом Міністерства юстиції 12 грудня 2011 року № 3502/5, зареєстрованим у Міністерстві юстиції 12 грудня 2011 року за№ 1429/20167; Наказ Міністерства юстиції України від 17.04.2012 № 595/5 «Про впорядкування відносин, пов'язаних із державною реєстрацією речових прав на нерухоме майно та їх обтяжень», зареєстрований у Міністерстві юстиції України 20.04.2012 за № 590/20903; Наказ Міністерства юстиції України від 03.12.2012 № 1779/5/748 «Про деякі питання забезпечення інформаційної взаємодії органу, що здійснює ведення Державного земельного кадастру, та органу державної реєстрації прав», зареєстрований у Міністерстві юстиції України 10.12.2012 за № 2056/22368; Наказ Міністерства юстиції України від 14.12.2012 № 1841/5 «Про внесення змін до деяких наказів Міністерства юстиції України у зв'язку iз запровадженням державної реєстрації речових прав на нерухоме майно та їх обтяжень», зареєстрований в Міністерстві юстиції України 19.12.2012 за № 2114/22426; Наказ Міністерства юстиції України від 14.12.2012 № 1844/5 «Про затвердження Порядку використання даних Реєстру прав власності на нерухоме майно, Сдиного реєстру заборон відчуження об'єктів нерухомого майна, Державного реєстру іпотек та Державного реєстру обтяжень рухомого майна», зареєстрований в Міністерстві юстиції України 18.12.2012 за№ 2102/22414 тощо [4]

Як бачимо, на сьогоднішній день існує велика кількість нормативно-правових актів, у яких розібратися «простій» людини дуже складно. А також суперечливість одного нормативно-правового акта іншому ще більше ускладнюе надання публічних послуг суб'єктами публічної адміністрації у сфері державної реєстрації речових прав на нерухоме майно, чим, у свою чергу, затримується або гальмується процес отримання цих публічних послуг суб’єктами звернення.

\section{Висновки}

Підбиваючи підсумки підрозділу, зазначимо, що правові акти, які регулюють суспільні відносини надання публічних послуг суб'єктами публічної адміністрації у сфері державної реєстрації речових прав на нерухоме майно, класифіковано за: юридичною силою 
(закони України, підзаконні нормативні акти); об'єктом регулювання (ті, які регулюють поведінку людей, визначають права й обов'язки суб'єктів зверення надання публічних послуг як учасників адміністративно-правових відносин; та ті, які визначають правовий статус підрозділів державної реєстрації речових прав на нерухоме майно); предметом регулювання (нерухоме майно (квартира, будинки, гаражі тощо); консультаційна допомога, довідкова та інформаційна робота, оформлення матеріалів 3 питань нерухомого майна).

На підставі аналізу нормативно-правових актів до основних прогалин у правовому регулюванні надання публічних послуг суб'єктами публічної адміністрації у сфері державної реєстрації речових прав на нерухоме майно у цьому напрямі віднесено: відсутність концепції надання публічних послуг підрозділами з державної реєстрації речових прав на нерухоме майно; нормативна незакріпленість критеріїв оцінювання ефективності якості надання публічних послуг діяльності суб'єктів публічної адміністрації; порушення принципів надання публічних послуг, колізії в нормативно-правовому регулюванні надання публічних послуг у сфері державної реєстрації речових прав на нерухоме майно тощо.

\section{Лiтepaтypa}

1. Тимощук В.П. Адміністративна процедура та адміністративні послуги. Зарубіжний досвід і пропозиції для України. К.: Факт, 2003. 496 c.

2. ОстрахМ.Б.Поняттяадміністративних послуг: теоретичний аспект. Держава $і$ право : збірник наукових пращь. К., 2009. С. 155-159.

3. Конституція України. Відомості Верховной Ради Украйни. 1996. - № 30. Ст. 141.

4. Офіційний сайт Державної реєстрації та нотаріату. [Електронний ресурс]. URL.: http:// http://ddr.minjust.gov.ua/uk/4424bbf47a bcd8a3a6f65ca7a0256435/normatyvnopravova baza/

5. Конвенція, що скасовує вимогу легалізації іноземних офіційних документів (укр/ рос): Гаазька конвенція від 05.10.1961 р. Оøбiиүйний вісник Украӥни. 2003. № 46. Ст. 2419.

6. Конвенция о защите прав человека и основных свобод. Права человека: сб. универс. и регион, междунар. док. М., 1990. [Электронный ресурс] Режим доступа: http:/conventions.coe.int/ treaty/rus/treaties/html/005.htm

7. Конвенція про правову допомогу i правові відносини у цивільних, сімейних i кримінальних справах (укр/рос): Міжнародний документ від 22.01.1993 р. Обіиійний вісник Украӥни. 2005. № 44. Ст. 2824.

8. Про запровадження безпосередніх зносин органів юстиції України в рамках Конвенції про правову допомогу та правові відносини у цивільних, сімейних та кримінальних справах 1993 року в частині виконання доручень у цивільних справах: наказ Міністерства юстиції України від 02.08.2007 р.№ 597. [Електронний ресурс]. URL.: http:// www.zakon2.rada.gov.ua/laws/show/v597 323-07

9. Цивільний Кодекс України : Закон України від 16.01.2003 р. № 435-IV. Відомості Верховної Ради Украӥни. 2003. № 40-44. Ст. 356.

10. Сімейний Кодекс України : Закон України від 10.01.2002 р. № 2947-III. Голос Украӥни. 2002. № 38

11. Земельний Кодекс України : Закон України від 25.10.2001 р. № 2768-III. Відомості Верховної Ради Украӥни. 2002. № 3 4. Ст. 27.

12. Господарський кодекс України : Закон України від 16.01.2003 р. № 463-IV. Відомості Верховної Ради України. 2003. № 18. Ст. 144.

13. Про нотаріат : Закон України від 02.09.1993 р. № 3425-XII. Відомості Верховної Ради Украӥни. 1993. № 39. Ст. 383.

14. Про іпотеку : Закон України від 05.06.2003 р. № 898-IV./ Відомості Верховной Ради Украӥни. 2003. № 38. Ст. 313.

15. Про державну реєстрацію речових прав на нерухоме майно та їх обтяжень: Закон України від 01.07.2004 р. № 1952-IV. Відомості Верховної Ради України. 2004. № 51. Ст. 553.

16. Про оренду землі : Закон України від 06.10.1998 р. № 161-XIV Відомості Верховної Ради Украӥни. 1998. № 46-47. Ст. 280.

17. Про виконавче провадження : Закон України від 21.04.1999 р. № 606-XIV. Відомості Верховной Ради Украӥни. 1999. № 24. Ст. 207.

18. Про господарські товариства : Закон України від 19.09.1991 р. № 1576-XII. Відомості Верховної Ради Украӥни. 1991. № 49. Ст. 682.

19. Про відновлення платоспроможності боржника або визнання його банкрутом : Закон України від 14.05.1992 р. № 2343-XII. Відомості Верховної Ради Украйни. 1992. № 31.CT. 440. 


\begin{tabular}{|c|}
\hline 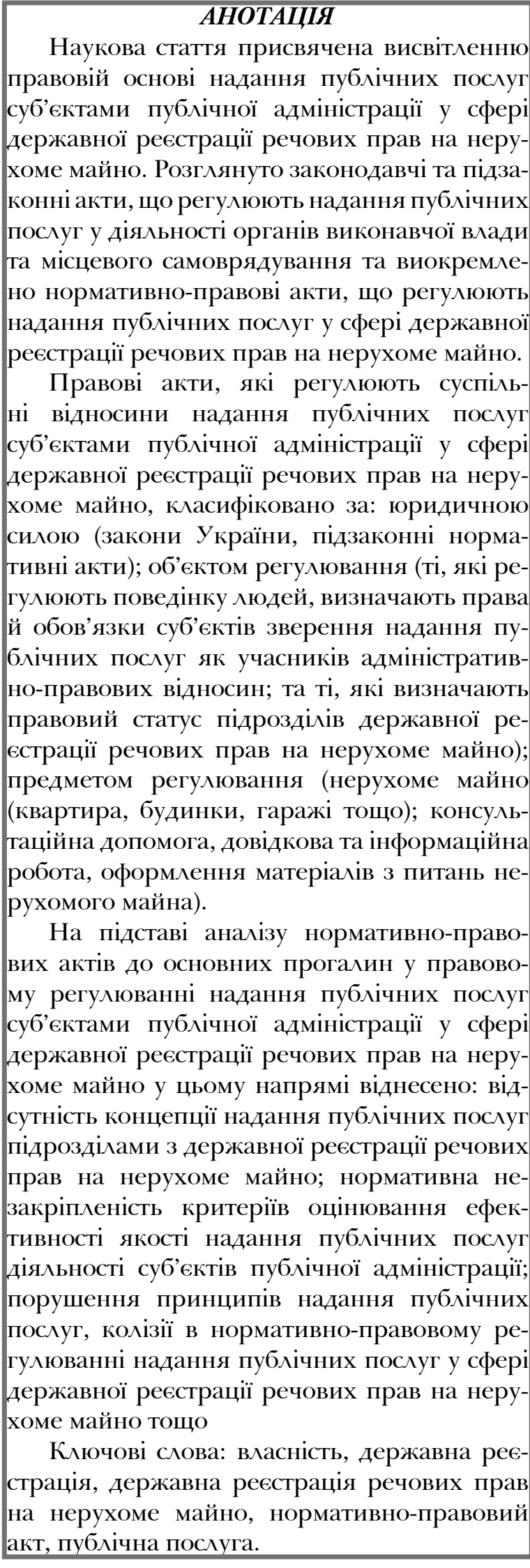 \\
\hline
\end{tabular}

\section{SUMMARY}

The scientific article is devoted to the coverage of the legal basis for the provision of public services by public administration entities in the field of state registration of real property rights. Legislation and bylaws regulating the provision of public services in the activities of executive authorities and local governments are considered, and regulations governing the provision of public services in the field of state registration of real property rights are highlighted.

Legal acts that regulate public relations for the provision of public services by public administration entities in the field of state registration of real property rights are classified according to: legal force (laws of Ukraine, bylaws); object of regulation (those that regulate the behavior of people, determine the rights and obligations of the subjects of public services as participants in administrative and legal relations; and those that determine the legal status of units of state registration of real property rights); subject of regulation (real estate (apartment, houses, garages, etc.); consulting, reference and information work, registration of materials on real estate).

Based on the analysis of regulations, the main gaps in the legal regulation of public services by public administration entities in the field of state registration of real property rights in this direction include: lack of concept of public services by units of state registration of real property rights; normative non-consolidation of criteria for assessing the effectiveness of the quality of public services provided by public administration entities; violation of the principles of provision of public services, conflicts in the legal regulation of the provision of public services in the field of state registration of real property rights, etc.

Key words: property, state registration, state registration of real rights to real estate, normative legal act, public service. 
НАУКОВО-ПРАКТИЧНИЙ ЖУРНАЛ

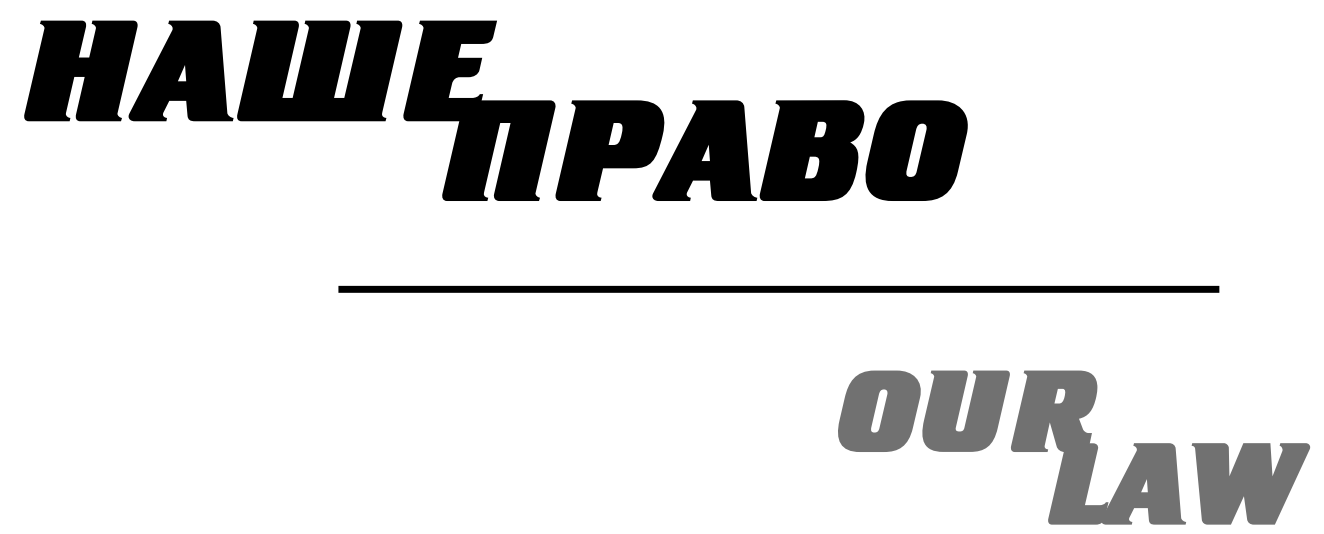

\section{Ne 3, 2020}

Головний редактор

Джаббарова О.в.

Здано до набору 28.02.2020 p.

Підписано до друку 03.03.2020 p.

Комп'ютерний набір. Формат 60x841/8. Папір офсетний.

Друк офсетний. Умовн. друк. арк 20,46

Тираж 1200. Зам. № 1222

ТзОВ «Дрогобицька міська друкарня» м.Дрогобич, вул. І.Мазепи, 7 ,

тел./факс 2-23-35, тел.: 3-38-50, 2-23-76 